\title{
ROCHAS METAMÓRFICAS DOS ARREDORES DE ITAPIRA - SP
}

\author{
ANTONIO CARLOS ARTUR
}

Dissertação de Mestrado apresentada ao Instltuto de Geocienncias da Universidade de Săo Paulo.

\section{Orlentador:}

Prof. Dr. Koji Kawashita
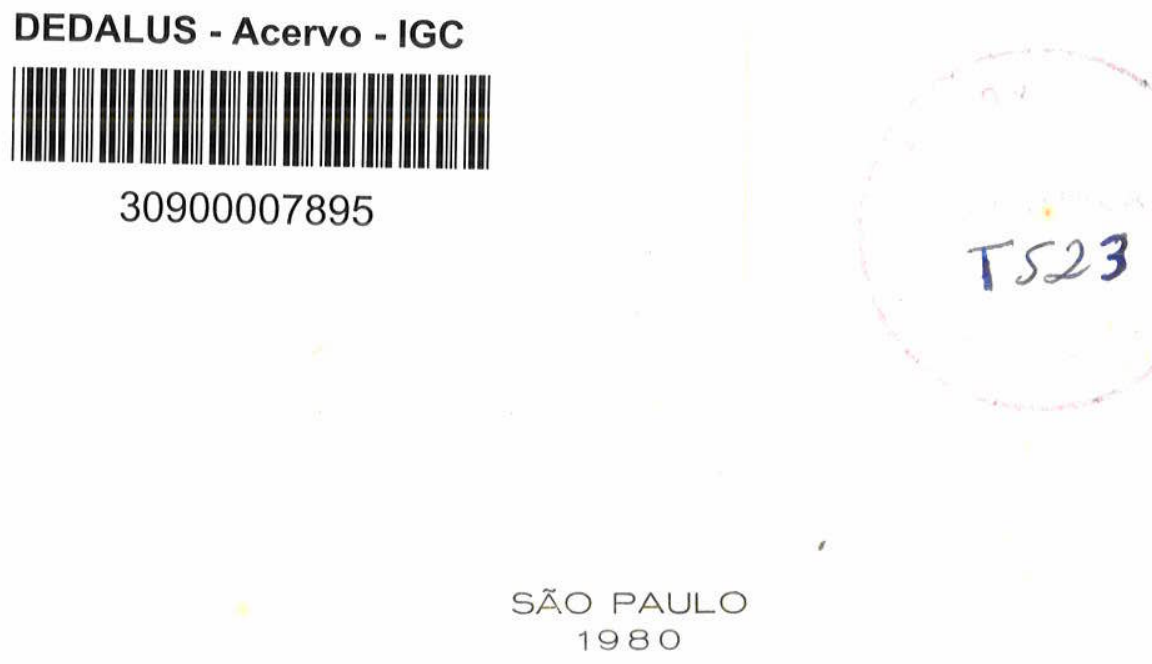
Aos meus pais, a minha esposa $e$ do meu fitho Julio Cesax. 
I. INTRODUÇAO

I.1. Objetivos do Trabalho

I.2. Localização e Extensão da Area

I.3. Aspectos Fisiogrāficos

I.4. Condições de Acesso

I.5. Metodologia do Trabalho

II. GEOLOGIA REGIONAL

II. I. Localização Tectônica

II.2. Mapeamentos Prévios

II.3. Dados Geolōgicos Regionais

II.4. Estratigrafia

III. ESBOÇO GEOMORFOLOGICO

IV. DESCRIÇAO DAS LITOLOGIAS

IV. 1. Rochas Sedimentares

IV.2. Granitōides Cataclasados

IV. 3. Rochas Metamörficas

V. PETROGRAFIA

V.1. Rochas Sedimentares

V.1.1. Rochas Sedimentares do Grupo Tubarão (PermoCarboniferos)

V.1.2. Rochas Sedimentares da Formação Rio Claro (Neo-Cenozöico)

V.1.3. Sedimentos Recentes

V.2. Granitöides Cataclasados

V.3. Rochas Metamörficas

1. Biotita e hornblenda gnaisses

2. Biotita e hornblenda gnaisses porfiroblästicos

3. Biotita e hornblenda gnaisses anatexiticos e migmatiticos

4. Gnaisses graniticos

5. Gnaisses pegmatiticos

6. Biotita ( \pm granada) xistos

7. Quartzitos 
8. Anfibolitos 86

9. Gonditos 91

10. Mārmores calcīticos 94

11. Meta-hornblenditos e -ultramafitos 96

12. Meta-argilitos,-conglomerados, -arenitos e - arcósios

13. Milonitos e cataclasitos

V.3.1. Estudo Quĩmico de Muscovitas 110

V.3.1.1. Resultados e Discussão 112

V.3.2. Fācies de Metamorfismo e Evolução Petrogenētị ca

VI. ASPECTOS ESTRUTURAIS

VI.1. Fases de Dobramento

VI.2. Estruturas Locais
VI.2.1. Procedimento de Campo e Tratamento dos Dados

VI.2.2. Elementos Estruturais

VII. DADOS GEOCRONOLŌGICOS

VII.1. Discussão dos Dados Radiomētricos K-Ar

VII.2. Discussão dos Dados Radiométricos Rb-Sr

VIII. OCORRENCIAS DE INTERESSE ECONÔMICO

IX. TENTATIVA DE UMA SINTESE DA EVOLUÇÃO GEOLOGICA

X. CONCLUSÕES

XI. AGRADECIMENTOS

179

XII. BIBLIOGRAFIA 
Figura 1 - Localização da ārea mapeada.

Figura 2 - Esboço geotectônico da parte sul do Crāton de São Francisco (Segundo Ebert, 1956).

Figura 3 - Mapa geológico do Leste do Estado de São Pauto e Sul de Minas Gerais (Segundo Ebert, 1968).

Figura 4 - Mapa geolögico simplificado da região Nordeste do Estado de São Paulo e Sul de Minas Gerais (Segundo Fiori, Wernick e Bittencourt,1978).

Figura 5 - Relação entre a \%(Mgo + Fe0 tot $)$ da muscovita e a $\%\left(\mathrm{MgO}+\mathrm{FeO}_{\text {tot }}\right) \mathrm{da}$ rocha total para os musco vita quartzitos da região de Itapira-SP.

Figura 6 - Relação entre os ions de Fe e Mg das camadas octaedrais das muscovitas em função da tempera tura.

Figura 7 - Relação entre os fons de Fe das camadas octaedrais e de $\mathrm{Na}$ das posições interlamelares das muscovitas em função da temperatura.

Figura 8 - Relação entre o Mg das camadas octaedrais e o $\mathrm{Na}$ das posições interlamelares como indicador baromētrico.

Figura 9 - Variação do aluminnio de coordenação tetraëdrica nas muscovitas da região de Itapira-SP.

Figura 10 - Estrutura a Leste da Fazenda do Jardim.

Figura 11 - Estrutura Sinformal de Itapira.

Figura 12 - Divisão da ārea mapeada "em Setores",para fins de caracterização de elementos estruturais.

Figura 13 - Diagramas de contorno de pōlos das normais lob tidos na rede Schmidt-Lambert, hemisfërio inferior) a foliações dos setores 1 e 2.

Figura 14 - Diagramas de contorno de pōlos das normais (ob... tidos na rede Schmidt-Lambert, hemisfërio infe rios) a foliações dos setores 3 e 4 . 
Figura 15 - Diagramas de contorno de pōlos das normais (obtidos na rede Schmidt-Lambert, hemisfērio inferior) a juntas dos setores 1 e 2 .

Figura 16 - Diagramas de contorno de pōlos das normais (obtidos na rede Schmidt-Lambert, hemisfērio infe rior) a juntas dos setores 3 e 4 .

Figura 17 - Diagrama de contorno de pölos das normais (obti do na rede Schmidt-Lambert, hemisfério inferiō) aos planos de falhas e planos de foliação em mi lonitos, de todos os setores.

Figura 18 - Diagrama de contorno de pōlos das normais (obti do na rede Schmidt-Lambert,hemisfério inferior) a veios de quartzo e pegmatitos de todos os setores.

Figura 19 - Diagrama isocrōnico Rb/Sr do gnaisse granĩtico e do biotita gnaisse porfiroblāstico do aflora mento 14 .

Figura 20 - Ampliação de parte do diagrama isocrōnico da figura 19.

Figura 21 - Isōcrona Rb/Sr do gnaisse Amparo do afloramen to 18 .

Figura 22 - Isócrona Rb/Sr do biotita gnaisse do afloramen to 19 .

Figura 23 - Diagrama isocrōnico Rb/Sr do gnaisse granïtico do afloramento 100 e do biotita gnaisse do afloramento 22 .

Figura 24 - Diagrama isocrōnico Rb/Sr dos migmatitos dos afloramentos 58 e 59 .

Figura 25 - Representação sinōptica das isōcronas das rochas metamórficas dos arredores de Itapira-SP.

Tabela 1 - Composição química parcial de muscovitas dos muscovita quartzitos da região de Itapira-sp 
Tabela 2 - Förmula estrutural, expressa na base de 22 ātomos de oxigênio, das muscovitas dos muscovita quartzi tos da região de Itapira-SP.

Tabela 3 - Determinações dos teores de Feo e MgO dos muscovi ta quartzitos da região de Itapira-SP.

Tabela 4 - Mãximos em ordem de frequência obtidos a partir dos diagramas de contorno das figuras 13 e 14 para atitudes de foliação dos setores $1,2,3$ e 4 dos arredores de Itapira-SP.

Tabela 5 - Mäximos em ordem de frequéncia obtidos a partir dos diagramas de contorno das figuras 15 e 16 para as atitudes de juntas dos setores $1,2,3$ e 4 dos arredores de Itapira-sP.

Tabela 6 - Idades $k$-Ar de rochas dos arredores de ItapiraSP.

\section{F $0 \mathrm{~T} O \mathrm{O} \mathrm{S}$}

Foto 1. - Granitōide cataclasado. Margem esquerda do Cörrego da Fazenda Velha, prōximo da sua confluência com o Rio Mogi-Guaçu.

Foto 2 - Biotita hornblenda gnaisse bandeado a fitado. Fazenda do Matão.

Foto 3 - Biotita gnaisse bandeado. Cörrego da Cristālia a oeste da Fazenda Cristālia.

Foto 4 - Migmatito. Neossoma discordando levemente da foliação do paleossoma, com contatos nītidos. Ro dovia Itapira-Lindöia, Km 26.

Foto 5 - Migmatito. Predomināncia do neossoma sobre o paleossoma. Rodovia Itapira-Lindōia, Km.26.

Microfoto 1 - Textura "fluidal" em leitos quartzo-feldspäticos de biotita hornblenda gnaisse. Nicois $x$, 
aumento $25 x$.

Microfoto 2 - Hornblenda diopsidio gnaisse. Reação diopsidio-hornblenda. Nicois//, aumento,.32x. 53

Microfoto 3 - Epidoto zonado. Nicois $x$, aumento $100 x$.

Microfoto 4 - Hornblenda diopsidio gnaisse. Contato entre lejto rico em diopsidio (claro, parte inferior) e leito rico em hornblenda (escu ro). Nicois//, aumento 10x.

Microfoto 5 - Muscovita quartzito com grãos de quartzo fraturados, extinção ondulante e bandas de deformação. Nicois $x$, aumento 10x.

Microfoto 6 - Andesina-anfibolito, notando-se vestigios de textura granular. Nicois//, aumento $25 \mathrm{x}$.

88

Microfoto 7 - Andesina-anfibolito. Contato entre lejtos de cristais grandes. e pequenos de hornblen da. Nicois//, aumento 10x.

Microfoto 8 - Meta-hornblenditos. Textura nematoblästica por justaposição. Nicois//, aumento 10x.

Microfoto 9 - Cataclasito com textura "mortar". Nicois $x$, aumento $25 x$.

\section{A P E N D I C E}

Apēndice 1 - Dados analiticos Rb-Sr.

\section{$A N E X O S$}

Mapa litolögico-estrutural dos arredores de Itapira-sp

Mapa de localização dos afloramentos 


\section{INTRODUÇAO}

\section{I.1. Objetivo do Estudo}

O principal objetivo do presente trabalho, $\bar{e}$ o ma peamento litolögico-estrutural em semi-detalhe na escala de 1:50.000 de uma ārea de cerca de $430 \mathrm{~km}^{2}$, envolvendo principal mente rochas cristalinas que circundam a borda oriental da Sine-clise da Bacia do Paranä nos arredores de Itapira. 0 trabalho proposto, constitui inicialmente, uma tentativa de conhecer a forma, o comportamento estrutural e as relações de contato entre diferentes unidades lito-estruturais, bem como a conseqüente caracterização petrogräfica dos diversos tipos litolōgicos. Alēm disso, com o auxïlio de critērios estruturais e datações radiomë tricas, tentamos enquadrar a ārea em foco no contexto da evolü ção geolögica regional.

\section{I.2. Localização e Extensão da Area}

A ārea mapeada localiza-se na Região Nordeste do Estado de São Paulo, na divisa com o Estado de Minas Gerais. E Timitada pelos meridianos $46047^{\prime}$ e $46953^{\prime}$ WG e pelos paralelos $22018^{\prime} \mathrm{e} 22030^{\prime} \mathrm{S}$, correspondendo a uma ārea de aproximadamente $430 \mathrm{~km}^{2}$ (Fig. 1). Abrange parcialmente as folhas de Mogi-Guaçu e Aguas de Lindóia, respectivamente com os cödigos SF-23-Y-AIII-3 e SF-23-Y-A-III-4 dentro da folha ao milionessimo do Rio de Janeiro.

Situa-se na ärea a cidade de Itapira es vilarejos de Barão de Ataliba Nogueira, Eleutērio e Sapucaì. Politicamente envolve parte dos municipios paulistas de Itapira (ocupando a maior porção da ārea mapeada), Mogi-Mirim a W, Aguas de Lin dóia e Lindōia a SE e parte dos municípios mineiros de Jacutinga a NE e Monte Sião a $E$.

\section{I.3. Aspectos Fisiogräficos}

Com exceção de uma faixa a $W$ da cidade de Itapi- 



LOCALIZACÃ̃o DA ÁREA

Figura 1 - Localização da ārea mapeada.

ra, com relēvo plano ou ligeiramente ondulado, a ārea caracteriza se pelo predominio de topografia serrana, com desniveis topogrāf cos oscilando entre as altitudes aproximadas de 600 metros a $W$ e 1200 metros a $E$ da ārea. As altitudes mais elevadas situam-se no extremo leste e estão representadas pelas serras dos coutos, do Combate, do MaTheiro e do Matão, na divisa dos Estados de São Pau lo e Minas Gerajs, chegando os desnivejs a mais de 300 metros.

Os maiores escoadouros da ārea são os Rios do Peixe e Eleutērio, afluentes da margem esquerda do Rio Mogi-Guaçu,am bos com sentido de escoamento para noroeste. O Ribeirão da Penha, 
aftuente da margem esquerda do Rio do Peixe, tambëm possui carāter expressivo. Penetra ao sul da ärea com direção geral N-S atē pröximo a Itapira, onde então inflete para NW. Os vales mais desenvolvidos encontram-se ao longo de toda extensão do Ribeirão da Penha e em um trecho ao longo do Rio do Peixe entre a Fazenda São Jerōnimo, a leste de Itapira, ate sua desembocadura no Rio MogiGuaçu. Eles são representados por planīcies inundāveis na ëpoca das chuvas.

O clima da região e caracterizado pela existência de uma estação seca de inverno, com duração mëdia de 1 a 2 meses. A temperatura ē bastante variāvel em função das elevadas altitudes na àrea, sendo que a mëdia do mês mais frio na cidade situase entre 150 e $200 \mathrm{C}$, ficando abaixo de 150C, na zona serrana. Na classificação de Koppen ē um clima do tipo CWa, e na classificação do IBGE um clima sub-sēco e sub-quente (sub-tropical).

\section{I.4. Condições de Acesso}

A cidade de Itapira dista aproximadamente $160 \mathrm{~km}$ de São Paulo por rodovia asfaltada via Jundiai, e $70 \mathrm{~km}$ de Campinas, via Mogi-Mirim.

0 sistema viārio da região $\bar{e}$ bom, destacando-se as rodovias asfaltadas Mogi Mirim-Itapira-Lindōia (SP 147), situada na parte sul da ärea, e Amparo-Jacutinga, via Itapira (SP 352 MG 162) que atravessa toda a porção mediana da ärea com dispos ção geral NE-SW. A existēncia de vilarejos, bem como numerosas fá zendas, desenvolveu uma rede de estradas municipais e particula res na maioria das vezes em razoāvel estado de conservação,comple tando o sistema viārio que permite uma locomoção relativamente boa, facilitando as observações de campo.

A região ē tambēm servida pela Estrada de Ferro FE PASA, antiga Mogiana, que liga Itapira a Mogi-Mirim e a Jacutinga, cujo ramal tem disposição quase paralela äs rodovias ItapiraMogi Mirim e Itapira-Jacutinga.

\section{I.5. Metodologia do Trabalho}


te estudo foram as de rotina para trabalhos dessa natureza, envol vendo:

$$
\begin{aligned}
& \text { a- Consulta Bibliogrāfica } \\
& \text { b- Interpretação Fotogeolōgica } \\
& \text { c- Trabalhos de Campo } \\
& \text { d- Trabalhos de Laboratōrio } \\
& \text { e- Trabalhos Finais de Gabinete }
\end{aligned}
$$

\section{a. Consulta bibliogräfica}

A primeira etapa constou de uma pesquisa sistemäti ca, sob o ponto de vista bibliogräfico, de trabalhos geolögicos referentes a ärea de estudo. Foram consultadas, tambēm, publica ções de âmbito mais geral, bem como as que relatam fenômenos seme Thantes em outras āreas. Atravēs desse levantamento bibliogräfico foi possivel obter tanto as informações desejadas, como estabelecer prioridades dessas observações em função das finalidades propostas.

\section{b. Interpretação fotogeolögica}

A interpretação fotogeolögica foi efetuada em fotografias aēreas na escala $1: 25.000$, datadas de 1972 e adquiridas no Instituto Brasileiro do Cafē. A sistemātica de fotointerpretação baseou-se na apresentada por Soares e Fiori (1976), e permitiu traçar as principais feições estruturais e tectónicas, bem co mo delinear as principais zonas homōlogas. Posteriormente, com ba se nas folhas topogräficas de Mogi-Guaçu (Folha SF-23-Y-A-III-3)e Aguas de Lindōia (Folha SF-23-Y-A-III-4), na escala 1:50.000 do IBGE e convenientemente ampliadas por mëtodo fotogräfico para a escala 1:25.000, foi confeccionado, com o auxîlio do sketchmaster, um mapa fotolitolögico preliminar.

c. Trabalhos de campo

Durante os trabalhos de campo foram realizadas des crições das litologias, do manto de intemperismo, das formações superficiais, bem como efetuou-se a coleta de amostras e medidas de diversos parâmetros estruturais. Sempre que possĩvel, percor- 
remos a ārea perpendicularmente às estruturas regionais a fim de desenvolver perfis que melhor permitissem estabelecer unidades 1 itolögicas e sua estruturação interna, atingindo uma densidade mëdia aproximada de 1 ponto por $\mathrm{km}^{2}$.

Os trabalhos de campo foram desenvolvidos em um periodo de oito meses, perfazendo um total de 50 dias de campo. Apös cada etapa de campo, procuramos reinterpretar o mapa fotoli tolögico preliminar dos trechos percorridos, sendo esse procedimento adotado para toda a ārea atē a elaboração do mapa litolög co-estrutural final.

0 mapa fotolitologico com todos os detalhes das folhas topogräficas de Mogi-Guaçu e Aguas de Lindōia, juntamente com as fotografias aereas, se prestaram satisfatoriamente como base para a localização e locomoção durante os trabalhos de campo. Devido ao relativo bom estado de conservação do sistema viärio da região, o acesso para o levantamento geolögico foi, em parte, efetuado com veĩculo "Volkswagen Sedan 1500", porēm, em alguns locais, a impraticabilidade de se trafegar ou a inexistên cia de estradas, obrigou-nos a percorrer longos trechos a pé.

d. Trabalhos de Taboratōrio

Nesta fase foram realizadas as seguintes etapas:

1. exame microscōpico

No laboratörio foram analisadas macroscopicamente, com mais detalhes, todas as amostras coletadas. 0 exame microscō pico de cerca de 110 secções delgadas foi executado em microscōpio zeiss, modêlo standart WL, visando a caracterização dos diversos tipos litolögicos no tocante a composiçăo mineralögica e aspectos texturais. Igualmente nesta fase, foram escolnidas as amostras destinadas a estudos geocronolögicos e anälises quimicas quantitativas de muscovitas.

\section{2. datações radiomētricas}

As datações radiomētricas foram realizadas pelos mëtodos $\mathrm{K}-\mathrm{Ar}$ em minerais separados e $\mathrm{Rb}-\mathrm{Sr}$ em rocha total no 
Centro de Pesquisas Geocronolögicas da Universidade de São Paulo. A tēcnica utilizada para o mëtodo K-Ar, e sua precisão experimental, foram descritas em Amaral et al (1966). Os erros experimentais foram estimados em cada caso, de acordo com a qualidade das anälises efetuadas. As constantes empregadas nos cälculos foram:

$$
\begin{aligned}
& \lambda_{\text {tot. }}=0,530 \times 10^{-9} \text { anos }^{-1} \\
& \lambda_{\varepsilon}=0,585 \times 10^{-10} \text { anos }^{-1}
\end{aligned}
$$

$\%$ atom. $k^{40}$ em $k^{\text {tot }}=0,0119$

As anälises Rb-Sr foram efetuadas segundo a metodo logia apresentada por Torquato (1974). As concentrações de Rb e de $\mathrm{Sr}$ foram determinadas quantitativamente por fluorescēncia de raios $X$, com erros estimados inferiores a $3 \%$. As relações $\mathrm{Sr}^{87} / \mathrm{Sr}^{86}$ foram obtidas em espectrōmetro de massa da marca Varian-MAT, tipo $T H-5$, estando sujeitos a erros experimentais inferiores a $0,3 \%$. Os valores de $s r^{87} / \mathrm{sr}^{86}$ foram normalizados para $s r^{86} / \mathrm{sr}^{88}=0,1194$. As demais constantes utilizadas foram:

$$
\begin{aligned}
& \lambda_{\mathrm{Rb}}=1,42 \times 10^{-11} \mathrm{anos}^{-1} \\
& \mathrm{Rb}^{85} / \mathrm{Rb}^{87}=2,59
\end{aligned}
$$

\section{3. anālise quỉmica quantitativa de muscovitas}

O programa analitico foi efetuado no Laboratōrio de Microssonda do Instituto de Geociëncias da Universidade de São Paulo, empregando um instrumento de fabricação Applied ... Research Laboratories, modelo EMX-SM.

Para o trabalho analitico com a microssonda eletrō nica, foram utilizadas secções delgadas polidas. As secções foram cobertas com carbono, recorrendo-se a um metalizador modelo : CV144 da Consolidated Vaccuun corporation.

As condições de instrumentação foram as seguintes: potencial de aceleração $15 \mathrm{Kv}$, corrente de amostra $0,03 \mu \mathrm{A}$, tempo de integração nos contadores $10^{\prime \prime} \mathrm{e}$, diāmetro do feixe eletrōnico aproximadamente $1 \mu$ para elementos aparentemente estäveis e ampliados para cerca de $20 \mu$ para $0 \mathrm{Na}$ e $K$ que apresentam problemas de 
volatilização. 0 padräo utilizado foi a muscovita natural (Padrão 4, no 7) pertencente ao laboratörio. Os dados obtidos foram subme tidos a correções instrumentais (drift e background), bem como, aos demais fatores de efeito diferencial de matriz (absorção atomica, nümero atōmico e fluorescēncia secundäria), segundo o mētodo de Bence e Albee (1968).

Para cada amostra analisada, os valores. listados nas tabelas correspondem à mëdia aritmëtica de 100 determinações em grānulos diferentes. As förmulas químicas foram calculadas, em conformidade com Guidotti (1970), na base de 22 oxigēnios anidros. Os dados analiticos totais fecham-se entre 94 e $96 \%$, sendo que, a porção complementar, corresponde principalmente a $\mathrm{H}_{2} \mathrm{O}$ e, provavelmente, aos elementos quïmicos minoritārios $\mathrm{Ti}, \mathrm{F}$ e $\mathrm{Ca}$.

Para as amostras utilizadas no programa analitico das muscovitas, foram efetuadas anälises quimicas em rocha total para a determinação quantitativa de $\mathrm{Fe}$ (total) e $\mathrm{Mg}$. Tiveram como finalidade, um controle da variação na composição das muscovitas em relação à composição da rocha total. Estas anälises foram executadas por espectro-fotometria de absorção atōmica no Laboratōrio de Química Analitica do Departamento de Mineralogia e Petrolo gia do Instituto de Geociēncias.

e. Trabalhos finais de gabinete

Concluĩdas as anālises e a interpretação de todos os dados, procedeu-se a execução dos desenhos, organização das tabelas e grāficos, bem como à redação do presente trabalho.

0 mapeamento geolögico elaborado com a ajuda do mapa fotogeolōgico na escala $1: 25.000$, foi reduzido para a escala 1:50.000 para efejto de apresentação e para manter uma homogeneidade com outros mapeamentos executados, nesta escala, em āreas vi zinhas, tendo em vista futuras integrações regionais. 
II. GEOLOGIA REGIONAL

II.1. Localização Tectōnica

Considerando-se a compartimentação tectōnica

Prë-Cambriano paulista (Penalva e Wernick, 3973b), a ārea estudada situa-se no Bloco Jundiaí, limitado ao norte pela falha de Jacutinga, e ao sul pelas falhas de Jundiuvira e Itu, todas de caiater transcorrente. Constitui, na região, o substrato da borda oriental da Bacia do Paranā.

0 bloco tectónico ao norte da falha de Jacutinga ē designado Bloco Pinhal, sendo constituĩdo essencialmente por migmatitos altamente evoluĩdos e rochas graniticas. Este complexo re cebe a denominação informal de Grupo Pinhal (Wernick e Penalva, 1973) e estā embutido em metamorfitos das fācies anfibolito e gra nulito do Grupo Amparo. Jā o bloco ao sul ē conhecido como Bloco São Roque (Hasui et al., 1969), sendo constituĩdo por rochas epimetamörficas do Grupo São Roque.

Ainda segundo a proposição apresentada por Wernick (1978a), a ārea em foco situa-se inteiramente no Maciço de Guaxupē, que passaria a apresentar como limite SE os falhamentos de Jundiuvira e Itu, sendo constituído pelos Grupos Amparo e Pinhal e pelas Formações Eleutério e Pouso Alegre, alēm de possĩveis nücleos arqueanos.

Outra zona de ruptura importante è a representada pela falha de Inconfidentes, situada nas proximidades do contato norte do complexo granitico-migmatitico de Socorro, (Fig.4). As direções estruturais no Bloco Jundiaĩ são predominantemente...NE$\mathrm{SW}$; entre as falhas de Inconfidentes e de Jacutinga infletem para ENE-WSW e ao norte desta passam a exibir direção NW-SE.

\section{II.2. Mapeamentos Prévios}

De acordo com o mapa geológico de 1974 editado pe10 Instituto Geogrāfico e Geológico, na escala 1:1.000.000 a ärea em questão e regiōes adjacentes aparecem como constituĩdas por rochas Pré-Cambrianas, sendo representadas essencialmerte por gra 
nitos, gnaisses, migmatitos, quartzitos e rochas intrusivas ācidas anteriores ao Grupo São Roque.

Em 1979, atravēs do Projeto Sapucaī, o Departamen to Nacional da Produção Mineral publicou carta geolögica, na escala 1:250.000, de uma ārea de aproximadamente $70.000 \mathrm{~km}^{2}$ do SW do Estado de Minas Gerais e NE do Estado de São Paulo. Os objeti vos bāsicos do Projeto Sapucaí foram o mapeamento, remapeamento e integração da geologia regional, bem como a definição de āreas prioritārias para futuros estudos especīficos e cadastramento de ocorrēncias minerais.

Mapeamentos geológicos em semi-detalhe do cristalino foram executados circundando praticamente toda a ārea por nōs estudada, e estão assim distribuỉdos:

Ao sul, Wernick (1967) realizou um mapeamento na escala 1:50.000, na Quadrícula de Amparo, envolvendo pouco mais de $2.000 \mathrm{~km}^{2}$, onde abordou tanto os aspectos geolögicos gerais quanto os geomorfolōgicos, estruturais, econômicos e petrogrāfi$\cos$.

Ao norte, Rodrigues (1976) apresentou um mapeamen to geológico, na escala 1:50.000, de uma ārea que envolve parte da Falha de Jacutinga, onde o autor estuda detalhadamente os efeitos do metamorfismo cataciāstico registrado ao longo desta fa Tha transcorrente.

A leste, foi realizado um mapeamento geológico na escala 1:50.000, em convênio DNPM/FFCL de Rio Claro, (Wernick, 1977; coordenador) compreendendo as folhas de Ouro Fino e Borda da Mata (MG), totalizando uma ārea aproximada de $1.500 \mathrm{~km}^{2}$, onde tambēm são abordados os aspectos geolōgicos, geomorfolōgicos, estruturais, econōmicos e petrogrāficos.

\section{II.3. Dados Geolōgicos Regionais}

Nos ūitimos anos tem surgido um grande nūmero de dados geológicos, petrogrāficos, estruturais e geocronológicos referentes ā ārea cristalina do nordeste do Estado de São Paulo e sul do Estado de Minas Gerais. Este incremento de dados permitiram, recentemente, sīnteses sobre a evolução geolōgica, tectō- 
nica e metamōrfica da região, cujos traços gerais estão delineadas na Fig.4, sendo devidas principalmente a Wernick (1978 a,b), Fiori et al. (1978, 1980), Wernick e Penalva (1978b) e Wernick e Fiori (1979).

Apresentamos aqui um resumo da evolução do conhecimento do Prē-Cambriano da referida ärea, ocorrido nas ültimas dëcadas e principalmente nos ültimos anos. Para tanto nos basearemos em Wernick (1978a), complementando-o com o surgimento de novos dados.

0 modelo geolögico da ärea teve início com os tra balhos pioneiros realizados por Ebert a partir da década de 50 . Em 1956, o referido autor partiu da premissa de que os Grupos Pa raïba, Andrelāndia e São João Del Rei eram unidades estratigräf cas cronologicamente equivalentes, integrantes de um cinturão orogēnico do Prē-Cambriano Superior que se amoldaria em torno do Cräton de São Francisco. O Grupo São João Del Rei ē epizonal ou anqlimetamörfico e equivalente ao Grupo Bambuĩ; o Grupo Andrelān dia e mesozonal e o Grupo Paraỉba catazonal. Este corresponderia aos internídeos do cinturão geossinclinal, enquanto o Grupo Andrelāndia constituiria seus externīdeos. A vergēncia de ambos è dirigida contra o crāton cuja cobertura seria representada pe1o Grupo São Joäo Del Rei, gradualmente menos deformada no sentido do eixo do rio São Francisco.

Ainda, segundo Ebert (1968), os diversos grupos refletiriam diferentes ambientes de deposição, com o Grupo Paraí ba de sedimentação eugeossinclinal, o Grupo Andreländia de ambiente de transição de condições eu-para miogeossinclinais e o Grupo São João Del Rej sendo caracterizado por sedimentos clästi cos finos, predominantemente bem selecionados, e calcārios.

Ao sul de Belo Horizonte, na altura do paralelo 220S, o cinturão sofre uma bifurcação em dois ramos (Fig.2). Um, passa a infletir para noroeste contornando o cräton, tendo sido denominado de Araxaīdes, o qual, passando por Trēs Corações e Varginhas, penetra no Estado de Goiäs; o outro, constituíndo os Paraibides, penetra no Estado de São Paulo nas proximidades de Lindōia e Itapira, estendendo-se atē os Estados do Paranä e Santa Catarina. Ambos os ramos exibiriam zoneamentos com a ocorrência de 3 faixas distintas:uma central, que corresponderia aos 
internideos, representados estratigraficamente pelos Grupos Para ba e Juiz de Fora; uma faixa intermediäria que corresponderia aos externideos compreendendo estratigraficamente os Grupos Andrelān dia (Paraibides, MG), Itapira (Paraibides, SP) e Varginhas (Araxaîdes, MG) alēm dos Micaxistos Paraibuna, na Serra do Mar; e uma faixa externa, caracterizada por dobramentos e falhamentos suaves incluindo o Grupo São João Del Rei. Delimitada pelos dois ramos ocorre uma ārea triangular, recoberta a oeste pelos sedimentos da Bacia do Paranä, designada de Maciço Guaxupé (Almeida et al.,1976).

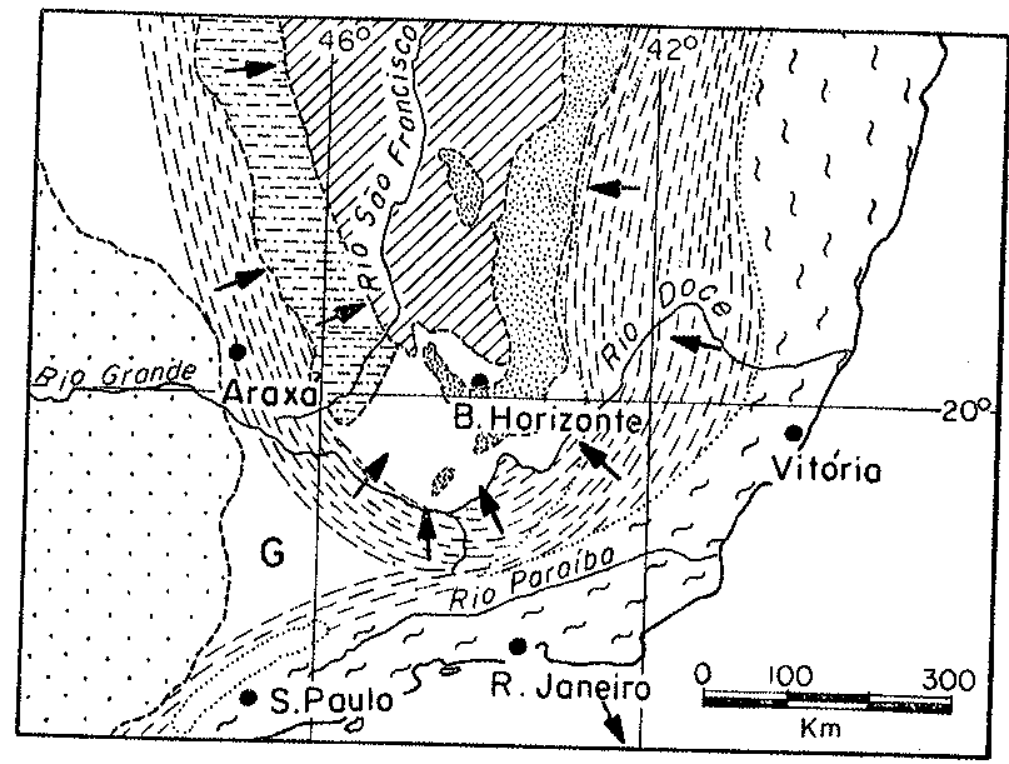

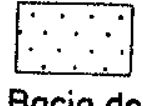

Bacio do Paranó



BAMBUI (comados Gerais)
BAMBUI (comodos Indaió)

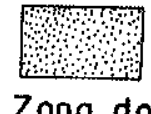

Zona do

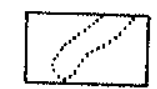

Provincio Pegmatitica
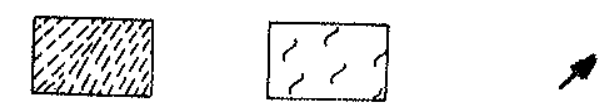

G

Externideos

Internideos Vergència

Macico de Gaxupé

Figura 2 - Esboço geotectónico da parte sul do Crāton de São Fran cisco (segundo Ebert, 1956).

O Grupo Barbacena, corresponderia a uma unidade mais antiga, referivel, conjuntamente à Formação Lafaiete, ao Dobramento Laurenciano (com cerca de $1.100 \mathrm{~m} . \mathrm{a}_{\text {.) }}$ ambos repousando sobre rochas mais antigas, representadas, na região, por migmatitos com idades ao redor de $2.300 \mathrm{~m} . \mathrm{a}$. e designadas por Ebert (1962) de Complexo Basal.

No decorrer de seus trabalhos, Ebert realizou suces sivas adaptações no modelo inicial, como consequência das variações da área de ocorrēncia e da extensão das diversas unidades estratigräficas continuamente criadas, redefinidas ou abandona- 
das, de acordo com o desenvolvimento dos mapeamentos e disponibi Tidades de novos dados.

Coube ainda a Ebert $(1968,1971,1974)$ correlacionar as unidades criadas e estudadas em Minas Gerais com as posteriormente caracterizadas no Estado de São Paulo. Assim correlacio nou, tentativamente o Grupo Barbacena (MG) com o Grupo Amparo, os Grupos São João Del Rei e Andrelãndia tambēm em Minas Gerais com - Grupo Itapira e interpretou a Formação Eleutērio como sendo cor relata ao Grupo Itajaí (Fig.3).



Figura 3 - Mapa geolōgico do leste do Estado de São Paulo e Sul de Minas Gerais (segundo Ebert, 1968).

Atravēs da execução de novos mapeamentos e investigações geocronolōgicas, surgiram as seguintes inovações quanto a geologia regional:

- Estudos de Pires et a1.(1970) referentes aos gonditos da região de Pouso Alegre revelaram a impossibilidade de en quadrar estas rochas quer no Grupo Barbacena, quer na Formação La faiete, utilizando os critērios metamōrficos, magmäticos e econōmicos empregados por Ebert (1957,1963). A continuidade da faixa de ocorrência dos gonditos atē os arredores de Itapira foi estabelecida por Wernick et a1. (1976a).

- Cordani et al. (1973) encontraram vestigios indicativos de superposições de três ciclos orogẽnicos nos Estados de 
Minas Gerais e Rio de Janeiro. O Grupo Barbacena teria a idade de $2.800 \mathrm{~m} . \mathrm{a} . ; 0$ Grupo Paraiba $2.000 \mathrm{~m} . \mathrm{a}$. e os granitos e migmatitos da Serra dos Orgãos $620 \mathrm{~m}$. a..

- De acordo com Wernick e Penalva (1973) não foi possivel, na região de Itapira, distinguir o Grupo Amparo do Gru po Itapira baseando-se nos criterios postulados por Ebert (1971), nem reconhecer o complicado padrão estrutural proposto pelo refe rido autor, representado por uma sucessão de sinclinais e anticlinais especiais, os primeiros ocupados pelo Grupo Itapira e os segundos pelo Grupo Amparo. Consideraram, em consequencia, ambas as unidades equivalentes, variando apenas no aspecto faciolōgico da sedimentação. Igualmente, os trabalhos desenvolvidos na região de Santa Rita de Caldas e Ipuiuna, no âmbito do ..convënio DNPM/FFCL de Rio Claro (Soares, 1976; coordenador), não permitiram constatar que as rochas referĩveis por Ebert ao Grupo Itapira ou Andrelāndia pertencessem a um ciclo orogênico mais novo que o gerador do Grupo Amparo.

- Penalva e Wernick (1973a) e Wernick e Penalva (1974a), estudando a região de Pinhal e Socorro, observaram a migmatização e feldspatização intensa da litologia do Grupo Ampa ro pela profusa intrusão de material granitico de idade brasilia na. A estas āreas migmatizadas denominaram informalmente de Grupo Pinhal e descreveram o controle do referido processo (Wernick e Penalva, 1978, 1980). A migmatização de rochas litologicamente equivalentes ao Grupo Amparo, por granitos brasilianos, foi tambëm constatada por 01 iveira (1973) e 0liveira e Alves (1974) nos arredores de São Josē do Rio Pardo. Tal fato representaria a caracterização do esquema proposto por Delhal et al. (1969) na Ser ra dos Orgáos tambēm no Leste do Estado de São Paulo.

- Wernick et al. (1976b) mostraram que o Grupo Am paro tambēm pertence ao Ciclo Transamazōnico não sendo possível, portanto, a sua correlação com o Grupo Barbacena. Atribuiram, igualmente, uma idade brasiliana aos maiores maciços graniticos do Teste do Estado de São Paulo, confirmando, neste ültimo caso, os dados de Cordani e Bittencourt (1967) e Ebert e Brochini (1968).

- Wernick (1978a, 1978b), baseado em dados geo10gicos, petrogräficos, geocronologicos e estruturais demonstrou, 
para a região nordeste do Estado de São Paulo e āreas . vizinhas do Estado de Minas Gerais situadas no Maciço de Guaxupē, uma evo lução policīclica, com rochas pertencentes ao ciclo Transamazōni co (Grupo Amparo) sendo afetadas por fenōmenos tectōnicos, magmä ticos e tērmicos do Ciclo Brasiliano. Alēm de demonstrar que cada ciclo tectōnico pode ser subdividido em värias fases e tendo caracterizado algumas delas; suspeitou tambēm da existēncia, na região, de nūcleos arqueanos que corlesponderia ao embasamento, localmente exposto, do Grupo Amparo. Da mesma forma propõe que - Iimite SE do Maciço de Guaxupē, atè então considerado pelo faThamento de Jacutinga, seja estendido até os falhamentos de Jundiuvira e Itu, tendo em vista que a primeira grande faixa de metassedimentos brasilianos (Grupo São Roque) sō ocorrem ao sul desses falhamentos. Assim, o Maciço de Guaxupē que constitui par te da região cristalina nordeste do Estado de São Paulo e āreas vizinhas do Estado de Minas Gerais é constituĩdo pelos Grupos Am paro (Ciclo Transamazōnico) e Pinhal (Ciclo Brasiliano) alēm das Formações Eleutērio e Pouso Alegre (Cjclo Brasiliano), e possiveis nücleos arqueanos.

- Fiori et al. (1978) revelaram, para a região, a existência de rochas ou eventos referĩveis aos ciclos Jequiē, Transamazōnico, Uruaçuano e Brasiliano. Tambëm caracterizaram vă rias fäcies de deformação ligadas a 3 fases principais de dobramentos referentes aos ciclos Transamazónico, Uruaçuano e Brasi1 iano, cujas direções estruturais principais estão em torno de ENE-EW, NS-EW e NNE-NE respectivamente, (Fig.4). Contudo, não foi possïvel caracterizar as fācies de deformação ligadas ä fase de dobramento associada ao ciclo Jequiē, jä que as fäcies de deformação da fase de dobramento associado ao Ciclo Transamazónico, que ocorre superimposto aos nücleos arqueanos presentes na ārea, apresentam intensa transposição e cisalhamento, obliterando quase totalmente as estruturas mais antigas. Ressaltaram tambēm que a região nordeste do Estado de Săo Paulo e äreas vizinhas do Estado de Minas Gerais apresentam uma histōria geolögica complexa e, que a anālise estrutural permite, em muitos casos, determinar a sua sequência evolutiva.

Este modelo foi sucessivamente detalhado sob o aspecto estratigräfico, tectōnico, petrogräfico e geocronolögico por Fiori (1979), Wernick e Fiori (1979), Arcur et al. (1979), 
Wernick et al. (1979), e Fiori et al. (1980).

tratada no item a seguir.

Destes trabalhos resulta a estratigrafia que serā

\section{4. Estratigrafia}

Com base nos dados previamente discutidos são reconhecĩveis na região em foco e arredores as seguintes : unidades cristalinas:

A - O Complexo de Silvianōpolis, de idade arqueana.

B - 0 Grupo Amparo, de idade transamazōnica, equivalente ao Grupo Itapira.

C - 0 Grupo Pinhal, de idade brasiliana.

D - As Formações Eleutērio e Pouso Alegre, tambēm de idade brasiliana.

E - O Maciço Alcalino de Poços de Caldas, de idade mesozöica.

Tambēm ocorrem a oeste da ārea, em contato com o cristalino, rochas sedimentares pertencentes a Bacia do Parană.

A distribuição destas unidades estä representada, de modo esquemātico, na Figura 4.

\section{A- Complexo de Silvianöpolis}

o Complexo de Silvianöpolis (Fiori, 1979), corresponde a uma ampla ärea constituĩda essencialmente por anatexitos do tipo embrechïtico, predominantemente cinzentos, de composição variāvel entre tonalītica e granodioritica a granitica. As rochas apresentam foliação proeminente quer pela disposição paralela de minerais estirados, quer pela alternäncia entre .. leitos quartzo-feldspäticos e leitos descontínuos enriquecidos em biotita e hornblenda. Localmente associam-se gnaisses porfiroblästicos e anatexitos irregulares do tipo flebitico ou schlierem. Fio ri (1979) demonstrou que os embrechitos são produtos de intensa transposição dos anatexitos flebiticos e schlierem, sendo reconheciveis naqueles ainda, localmente, dobras intrafoliares disrup tas e com ápices espessados. A textura dos migmatitos $\bar{e}$ predominantemente granoblästica e a dos embrechitos granoblästica- ca- 


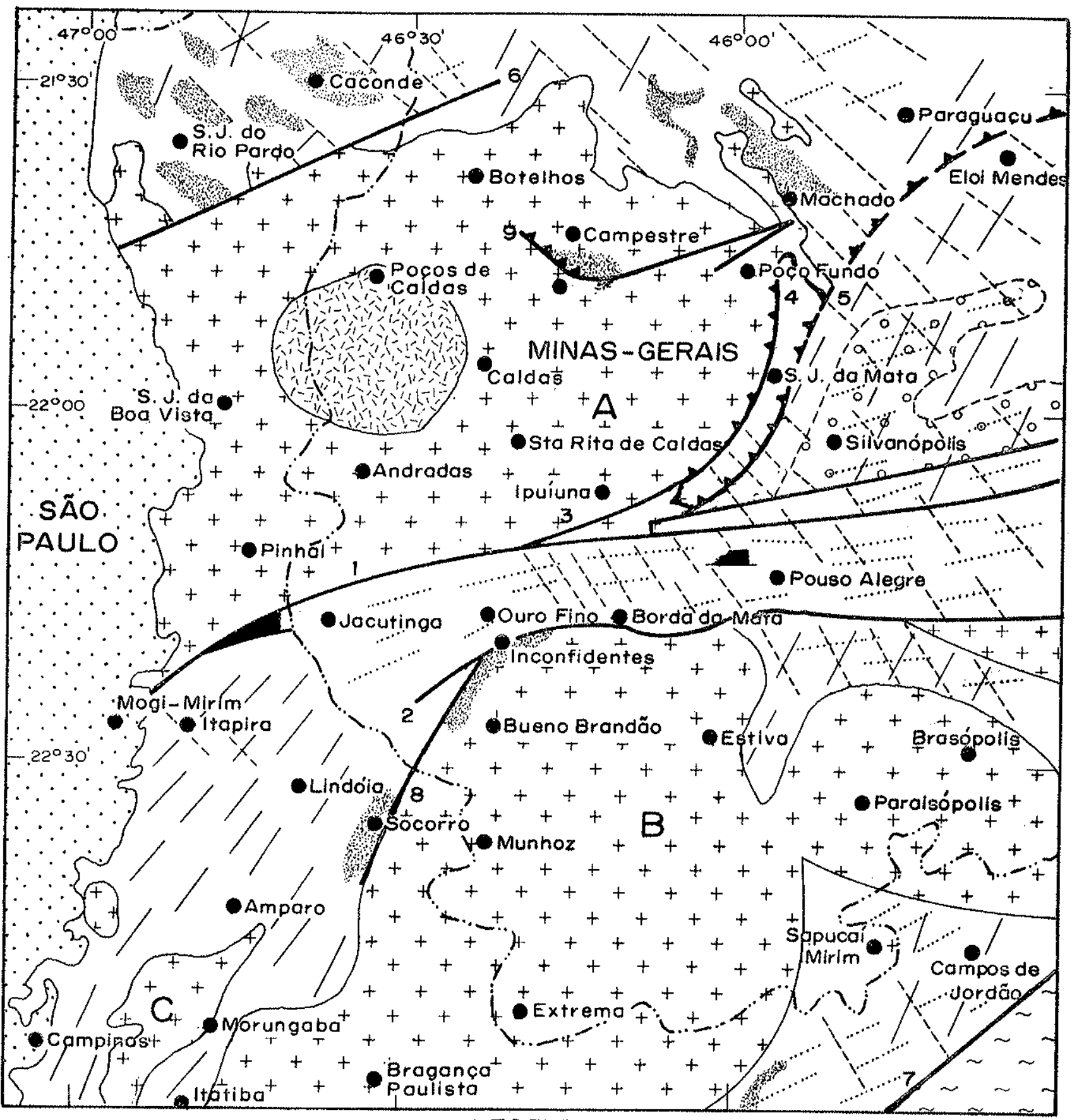

\section{LEGENDA}



$t^{+}+t^{+}$

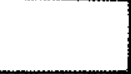

Áreas maiores de Granulitos e Charnoquitos do Grupo Amparo

$\left[\begin{array}{lll}0 & 0 & 0 \\ 0 & 0 & 0 \\ 0 & 0\end{array}\right.$

Sedimentos da Bacla de Taubaté

Sedimentos e Vulcânicas da Bacia do Paraná

Rochas Alcalinas Variadas do Macico de ogos de Caldos

Depósitos Molassóides das Formacóes Pouso Alegre e Eleutério

Granitóides e Migmatitos A - Complexo Pinhal do Grupo Pinhal $\quad$ C-Macico Morungabo Metasedimentos e Meto-Igneas variodo do Gruo Amparo

Complexo Anotexítico - Diotexítico de Silvionópolis
PRINCIPAIS FALHAS

1 - jacutingo

2-inconfidentes

3-ipuiúno

4 - Sốo João da Mata

5 - Espirito Sonto do Dourado

6-Divinolândio

7 -Santo Antonio do Pinhal

8-Socorro

9--Sço Pedro de Caldas

PRINCIPAIS DIREÇÕES ESTRUTURAIS

..... Transamazónicas

Uruquanas

Brasillanos

Cidode
Limite de Estado 
taciástica. Entretanto, em parte do Complexo, os embrechitos mos tram-se, em maior ou menor grau, recristalizados e mesmo remobilizados, indicando terem sido submetidos a fenōmenos térmicos pōs-deformacionais que chegaram a desencadear fenōmenos anatēcti cos. Ao Complexo de Silvianōpolis foi atribuida idade arqueana. Rochas semelhantes ocorrem como nücleos ou intercalaçöes tectōn cas no Grupo Amparo e no Grupo Pinhal (Wernick, 1967, 1978 a, b; Ebert, 1968; Choudhuri et a1., 1978; Artur et a1., 1979; Wernick e Penalva, 1980).

\section{B- Grupo Amparo}

O Grupo Amparo (Ebert, 1968) ocorre no Bloco Jundiai, situado ao norte dos falhamentos de Jundiuvira e Itu,assim como no Bloco Pinhal, localizado ao norte do falhamento de Jacutinga (Penalva e Wernick, 1973a). Para leste, sua ärea de exposi ção sofre um estreitamento local passando a constituir, entre so corro e ouro Fino, uma faixa situada entre os complexos granitico-migmatitico de Socorro e Pinhal, em relação aos quais exibe contatos eminentemente tectōnicos, dados pelos falhamentos trans correntes de Jacutinga e Inconfidentes.

Trata-se de uma unidade essencialmente metassedimentar cujo arcabouço litolögico ê representado por biotita e/ou hornblenda gnaisses com predominância generalizada de plagioclāsio entre os feldspatos. Subordinadamente ocorrem gnaisses porta dores de granada, diopsidio ou sillimanita. As rochas exibem estrutura listrada, fitada ou bandada e a textura è predominantemente granoblāstica-cataclāstica. E comum a ocorrēncia de gnaisses anatexiticos (metatexitos) e anatexitos que podem evoluir atē diatexitos e granitos autōctones, heterogēneos. Neste arcabouço ocorrem intercalações frequentes e extensas de gnaisses graniticos, gnaisses porfiroblästicos, quartzitos com diferentes estruturas e conteūdo mineralögico, e gonditos. Hornblenda gnais ses e anfibolitos, localmente frequentes, exibem ampla variação na estrutura (maciça, xistosa, listrada), textura e composição. 0 correm, ainda, corpos restritos de märmores e rochas calco-silicatadas. Metapelitos são representados por muscovita e biotita ( granada, \pm sillimanita, \pm cianita) xistos e gnaisses. Rochas ultrabāsicas (dunitos, peridotitos, piroxenitos) ocorrem sob a 
forma de sills e diques, com esporädicos leitos de cromititos e magnetitos. Relativamente comuns são rochas granuliticas e char noquiticas, cujas maiores āreas de ocorrência estão assinaladas na Fig.4. São tanto para-quanto ortometamörficas, indicando, nes te caso, resultarem de uma sequēncia magmätica calco- alcalina diferenciada (0liveira, 1973).

Entretanto, Fiori (1979) redefiniu o Grupo Amparo, retirando de sua litologia as rochas granuliticas, embrechI ticas, gnaisses graniticos, certos gnaisses porfiroblästicos e alguns tipos de anatexitos, referindo-os ao embasamento desta $\underline{u}$ nidade do Proterozóico Inferior. Tal redefinição confere-lhe um carāter essencialmente metassedimentar, representando uma solu ção para a controvërsia entre os Grupos Itapira e Amparo.

Apesar de não estar ainda refinada uma estratigra fia interna, Wernick (1978b) e Artur et a1., (1979) reconheceram 10 associações litológicas com características distintas, todas passiveis de mapeamento. A 1 itologia sugere um espesso pa cote de sedimentos prē-metamōrficos clasto-psamīticos a peliticos e clasto-químicos, predominantemente impuros, com intercala ções de tufos e restritos sedimentos químicos, ao lado de quantidades variāveis de corpos ígneos bäsicos e ultramäficos.

0 padrão estrutural apresentado pelas rochas do Grupo Amparo è complexo, com evidēncias de redobramento e trans posição. 0 metamorfismo è da fäcies anfibolito, chegando a provocar fenómenos de anatexia com a formação de metatexitos diver sos e localmente diatexitos. Em muitos casos,especialmente no Complexo de Silvianōpolis, dada a intima associação entre rochas do Grupo Amparo e as do seu embasamento, torna-se extremamente difícil a distinção entre os anatexitos formados a partir dos metassedimentos do Grupo Amparo e os resultantes da remobilização do seu substrato arqueano.

As rochas do Grupo Amparo tambēm exibem isinais de polimetamorfismo, caracterizado pelo desenvolvimento de saus suritização dos plagiocläsios, formação de clorita a partir de granadas e biotita, desenvolvimento marginal de biotita em anfibōjios, etc., indicando a superposição de condições metamōr ficas majs brandas sobre paragēneses geradas sob condições mais 
intensas. Descriçöes mais pormenorizadas da litologia do Grupo Amparo são devidas a Franco e Coutinho (1957), Gomes et al (1966), Wernick (1967, 1972a,b, 1977), Pires et al. (1970), 01iveira e Alves (1974, 1976), 0liveira (1973), 01iveira e Hyppolito (1973), Wernick e Artur (1974), Wernick et a1. (1976a), Soares (1976), Choudhuri et al. (1977), Choudhuri e Fiori (1978) e Fiori (1979).

\section{Grupo Pinhal}

0 Grupo Pinhal è representado, na ärea em foco, por dois grandes complexos granitico-migmatiticos: Pinhal e socorro (Fig.4). 0 Complexo Pinhal situa-se ao norte da Faixa de Transcorrência de Jacutinga-Ipuiuna (Wernick e Penalva, 1973; Pe nalva e Wernick, 1973b; Ebert 1968; Rodrigues 1976), sendo encoberto a oeste pelos sedimentos da Sinēclise do Paranä; para leste estende-se atê as proximidades da cidade de São joão da Mata (MG). O seu limite norte estende-se alēm das cidades de Botelhos e São Josē do Rio Pardo. Sua ärea de ocorrēncia ē da ordem de $7.000 \mathrm{~km}^{2}$.

O Complexo de Socorro situa-se ao sul da Faixa de Transcorrência de Inconfidentes (Soares, 1976; Wernick, 197.), desde as proximidades da cidade de Socorro (SP), ate a oeste da Tocalidade de Brasōpolis (MG). Para o sul estende-se alëm da cidade de Bragança Paulista, atē as proximidades de Sapucaí llirim e Campos do Jordão. Sua ärea de exposição, delimitada na Figura 4 , e da ordem de $6.300 \mathrm{~km}^{2}$.

Uma extensão ocidental do Complexo de Socorro constitui o Maciço de Morungaba, situado a $5 \mathrm{~km}$ deste complexo e com ärea aproximada de $330 \mathrm{~km}^{2}$ (Wernick, 1972c). Expansões semelhantes, relacionadas ao Complexo Pinhal, ocorrem na sua porção $N$ e $N E$, nas proximidades de São Jose do Rio Pardo (SP) e Machado (MG).

0 Grupo Pinhal è uma unidade granitico-migmatitica, de idade brasiliana, resultante de profusa intrusão de grani töides, em rochas do Grupo Amparo, constituîndo grandes complexos. Os granitōides são de natureza variävel, incluindo termos equigranulares, finos e grosseiros, rosados, cinzentos ou esbran quiçados, e rochas porfirōides, isotrōpicas ou gnaissificadas. 
Sua composição varia globalmente de granitica a quartzo-dioritica, incluindo termos sieniticos. Entre os termos equigranulares são comuns rochas com grandes cristais arredondados de quartzo, indicando origem subplutônica. Nas rochas porfirōides os megacristais são predominantemente de microclinio, ao lado de menores quantidades de oligoclásio. São de cor rosada, cinzenta ou esbranquiçada. Podem alcançar atē $15 \mathrm{~cm}$ e são retangulares, ovalados ou irregulares. Estão inseridos numa matriz hipautomōrfica granutar mēdia a grosseira, de composição quartzo-dioritica a granitica, incluindo termos leucocráticos a mesocräticos. A composição mëdia global predominante das rochas é adamelitica. Des crições das rochas graniticas da região em foco são devidas a Wernick (1972 b,c), Wernick et al. (1976c) e Wernick e Penalva (1980). As intrusões são controladas por falhas e estruturas dobradas. Aos termos plutônicos e sub-plutōnicos associam-se diques de granitos pórfiros, pegmatitos e quartzo, cujo alojamento é controlado por fraturas e falhas.

os migmatitos são,na sua maioria, de cor rosa com estrutura acamada, agmatitica, de "schollen" e "schlieren", nebulitica, homofànica, dobrada e oftalmitica. Em alguns casos è possivel estabelecer-se um arranjo concêntrico dos migmatitos em torno das intrusões graniticas, com anel central de migmatitos homofânicos, nebuliticos ou de "schlieren", uma zona intermediäria com migmatitos "schollen" a agmatiticos e um anel externo de migmatitos acamados. A espessura e a configuração de cada ane é variāvel de acordo com a natureza da rocha migmatizada, podendo mesmo faltar. Pela interferëncia de värios corpos graniticos com aurēolas de migmatitos resultam complicados complexos granītico-migmatĩticos. A migmatização ē acompanhada de processos metassomäticos mais ou menos intensos que afetam não sö os diferen tes tipos de migmatitos mas tambëm as intercalações de rochas do Grupo Amparo, isentas de injeções de material granitico. 0 processo da blastese é controlado pela natureza das rochas e pelas estruturas locais e regionais.

Alëm dos trabalhos acima mencionados, descrições de algumas feições petrogrāficas e mineralógicas do Grupo Pinhal são devidas a Wernick (1972a), Wernick e Fernandes (1972), Wernick e Penalva (1974 a, 1978), Oliveira (1973), 01iveira e Alves (1974) e Gomes et al. (1976), bem como à elaboração de uma sỉnte 
se do referido Grupo por Wernick e Penalva (1980).

\section{Formações Eleutērio e Pouso Alegre}

Suas descrições, ainda incompletas, são devidas a Leonardos Jr. et al. (1971), Ebert (1974), Wernick e Penalva (1974b) e Rodrigues (1976). A Formação Eleutērio ocorre sob a forma de uma estreita faixa com direção NE-ENE/SW-WSW, medindo cerca de $11 \times 1 \mathrm{~km}$, iniciando-se nas imediações de Eleutērio e terminando na altura de Jacutinga $(M G)$, cerca de $5 \mathrm{~km} \mathrm{a}$ leste desta cidade. Seus limites, na porção ocidental, são predominantemente tectónicos, colocando-o em contato com o Bloco pinhal atravēs da falha de Jacutinga e, ao sul, em contato com o Grupo Amparo atravēs da brecha dos Machados. A Formação Pouso Alegre, a noroeste da cidade mineira homōnima, com espessura de 500 metros, acha-se embutida no Grupo Amparo atravēs de contatos eminentemente tectōnicos. Apenas em alguns lugares ē observada nīti da discordāncia angular em relação ao embasamento cristalino cir cundante.

Trata-se de sequëncias metassedimentares anquimetamōrficas a epimetamörficas, constitü̈das essencialmente por arenitos arcosianos e arcósios, localmente conglomeräticos e sili cificados. Associam-se meta-argilitos e meta-margas com clivagem ardosiana, brechas e conglomerados. As brechas e conglomerados são tanto oligomiticos, com seixos e fragmentos de meta- argilitos ou quartzo em matriz arcosiana, como polimiticos, com seixos de muscovita quartzitos, gnaisses e quartzo em matriz meta-psami tica a metampelitica.

A litologia e as estruturas sedimentares sugerem uma sedimentação em ambiente com energia altamente variāvel,clas sificada por Leonardos Jr. et a1.(1971) de deltäico, com estrutu ras de planicies de inundação, deltas propriamente dito e canais as sociados.

os dados ora disponiveis indicam que a: Formação Pouso Alegre ē algo mais metamōrfica que a Formação Eleutērio.Em ambas as unidades as camadas são inclinadas desde 450 atē verticais com direção em torno de N60E-S60W na Formação Eleutērio e em torno de $E-W$ na Formação Pouso Alegre. 
Ebert $(1971,1974)$ sugeriu que a Formação Eleuterio seria equivalente ao Grupo Itajaí e outros depōsitos ...molassōides ligados ao Ciclo Brasiliano. Tal interpretação foi confir mada por recentes dados geocronolögicos obtidos para calco- xistos (meta-margas) da Formação Pouso Alegre (Hama e Cunha, 1977). Entretanto, os dados de campo não puderam confirmar a : hipötese de Ebert (1971) de que a formação Eleutërio, depositada em bacia tectōnica, pudesse ser correlacionada com as camadas basais do Grupo Bambuĩ.

\section{E. Maciço Alcalino de Poços de Caldas}

- Maciço Alcalino de Poços de Caldas correspande a uma ampla cratera ovalada $(35 \times 30 \mathrm{~km})$ composta por uma associação variada de rochas alcalinas plutōnicas, hipo-abissais, efu sivas e piroclästicas. Nas suas imediações (e.g. arredores de Aguas da Prata e Pocinho do Rio Verde) e no seu interior (e.g.na Cachoeira Vëu de Noiva) ocorrem intercalações de sedimentos refe ríveis ao Grupo Tubarão. O maciço referido ao Terciārio Inferior corta o maciço sienitico de Pedra Branca que aflora junto à sua borda SE e que è referido ao Ciclo Brasiliano (Winters e :Ebert, 1978). O mapeamento e a descrição petrogräfica deste complexo, são devidas principalmente a Ellert (1959), Ellert et al. (1959) e Ulbrich et al. (1977).

\section{- Rochas Sedimentares da Bacia do Paranā}

As rochas sedimentares correspondem à borda nordeste da Bacia do Paranā em contato com o Embasamento :Cristalino, e pertencentes ao Grupo Tubarão.

A estratigrafia do Grupo Tubarão tem sido objeto de diversas pesquisas e constitui um problema de dificil solução. A subdivisão inicial em Formaçōes Itararē e Tatuĭ, para o Estado de São Paulo, como glacial e pös-glacial respectivamente, è a mais aceita (Washlurne, 1930; Mendes, 1962; Petri, 1964; Rocha Campos, 1967; Soares, 1972; Landim, 1973). Os trabalhos mais importantes na divisão estratigrāfica do Tubarão do Estado de Säo Paulo foram os de Barbosa e Almeida (1949) e Almeida e Barbo sa (1953), nos quais o pacote de sedimentos com contribuição gla 
cial $\bar{e}$ subdividido nas formaçöes: Itu, Capivari, Gramadinho e Tie têe, posteriormente acrescidas da Formação Elias Fausto (Barbosa e Gomes, 1958); e à sequência pōs-glacial foi dado o nome da Formação Itapetininga. Esta estratigrafia pode ser resumida da seguin te forma:

Formação Itu

- Arenitos grosseiros a finos, conglomerāt cos; varvitos, folhelhos e siltitos, diamictitos prōximo a base.

Formação Elias Fausto - Tilitos, arenitos.

Formação Capivari - Arenitos e siltitos, intercalações de foThelhos; conglomerados locais e seixos pingados.

Formação Gramadinho - Dois conjuntos de tilitos, separados por arenitos, folhelhos e varvitos; seixos pingados.

Formação Tietê

- Arenitos grosseiros a finos, siltitos e folhelhos, localmente conglomeräticos; ten tes de calcärio e camadas de carvão; diamictitos pröximo ao tōpo.

Formação Itapetininga - Membro Tatuĩ: arenitos finos e siltitos micäceos; silex de cor verde. Membro Tupi: arenitos e siltitos argilosos, com frequente estratificação cruzada; seixos e blocos; cor vermelho chocolate.

0 valor dessa divisão estä no fato de haver caracterizado distintos pacotes e lhes haver atribuido nomes; mas a inexistência de continuidade lateral de alguns pacotes e a ausencia de limites definidos entre um e outro, para merecer a designa ção de formações, constitui seu aspecto negativo. A falta de cama das guias, a densidade e a variabilidade de litologias que permitam estabelecer a equivalēncia dos corpos litolögicos aflorantes em pontos distintos, põe em dūvida a classificação desses autores.

Os aspectos estratigräficos regionais da bacia foram revistos recentemente por Soares e Landim (1973) e Soares et a1. (1977), à luz dos mapeamentos sistemäticos realizados no Esta 
do de São Paulo (Andrade e Soares, 1971; Soares et al.,1973; Soares 1974). A grande diversidade litolögica e a ausēncia de camadas guias que dificultam extremamente sua divisão em formações mapeäveis, levaram esses autores a considerar a divisão do Grupo Tubarão, no Estado de São Paulo, em Formação Tatuĩ (atribuĩdo ao Permiano mëdio por Soares, 1972) e Subgrupo Itararē (de idade Carbonifera superior; Petri, 1964); ou Permiana segundo Rocha Campos (1969), Amaral e Rocha Campos (1969). Por outro lado, notaram uma maior frequéncia de corpos arenosos na metade inferior e nos $\vec{u} l t i m o s ~ 100-200$ metros do Subgrupo Itarare (Este representa um pacote com aproximadamente $1000 \mathrm{~m}$ de espessura), que permitiu, com base na porcentagem de arenitos, subdividi-lo em tres pacotes. Assim, o "pacote inferior" corresponderia aproxima damente ā Formação Itu, com folhelhos rítmicos e ritmitos, subsi diariamente diamictitos, conglomerados e arenitos conglomerāticos na parte inferior, e arenitos texturalmente imaturos ou estratificados, com teor de matriz muito variāvel, grãos brilhan tes e angulosos, intercalando corpos de diamictitos, na parte su perior. 0 "pacote médio", corresponderia às Formaçöes Elias Faus to, Capivari e Gramadinho, caracterizado pela predominancia de siltitos, ritmitos e diamictitos. 0 "pacote superior" à Formação Tieté, sendo constituĩdo essencialmente de arenitos grosseiros e conglomerados, ocorrendo tambem diamictitos, etc. Todavia, os re feridos autores ressaltam que todas essas litologias ocorrem em todos os pacotes e nisso reside a dificuldade de, diante de um ou dois afloramentos, dizer em que nĩvel do Itararé se estaria. Portanto a designação de "formação" a esses pacotes deve aguardar trabalhos de mapeamentos, em āreas maiores, que esclareçam melhor os contatos entre uma e outra unidade. 


\section{ESBOÇO GEOMORFOLOGICO}

Com exceção de uma estreita faixa de rochas sedimentares da Bacia do Paranä no limite ocidental, correspondendo a Depressão Perifērica, a ārea abordada situa-se na zona Cristalina do Norte, segundo a classificação de Almeida (1964). Nesta ürtima, podem ainda ser distinguidas as superficies erosivas Itaguă e Ja$p i$.

A Superfīcie Itagua $\vec{a}$, amplamente predominante ärea estudada, que se inicia a $w$ da linha da Serra Aguas ClarasSerra dos Coutos, merguina suavemente (cerca de $25 \mathrm{~m} / \mathrm{Km}$ ) por baixo das rochas sedimentares da Bacia do Parană, sendo continuamente e xumada pela remoção da cobertura sedimentar permo-carbonifera.

A Superficie Japi ou das Cristas Mëdias, estaria representada por uma pequena faixa a partir da Serra das Aguas Claras na porção SE, que contorna o limite oriental da ärea atē seu retorno na Serra dos Coutos, acompanhando aproximadamente o limite dos Estados de São Paulo e Minas Gerais atē a nascente do Rio Eleutērio, prolongando-se alēm da ärea.

A ārea correspondente à Bacia do Paranā, constitu da, na porção focalizada, por sedimentos glaciais, caracteriza-se por um relévo plano ou ligeiramente ondulado, com vales amplos e rasos e uma drenagem pouco densa, irregular, e que não reflete a estrutura infra-sedimentar. Devido à pequena espessura das rochas sedimentares, a maioria dos leitos dos cursos d'ägua situam-se em rochas cristalinas. Tambëm pela remoção de sua cobertura, as rochas cristalinas afloram nas partes topogräficas mais altas, circundadas pelas sedimentares. Como incremento do processo erosivo, as rochas cristalinas vão sendo sucessivamente exumadas ficando as rochas sedimentares 1 imitadas ā äreas deprimidas. Estes restos de sedimentos podem, pela regressão continua da orla da Bacia do Parană, afastar-se da mesma por longos trechos. Assim Martin et a]. (1959), descreveram a ocorrēncia de restos de depösitos fluvio-glaciais, afastados em mais de $30 \mathrm{~km}$ do limite atual da Bacia do Paranā.

0 relévo suavemente ondulado que caracteriza

ärea das rochas sedimentares permo-carboniferas, estende-se tambēm por uma larga faixa no terreno gnäissico circunvizinho, resul 
tando em vales amplos e poucos profundos, com espessa $\therefore$ cobertura de regolitos, dificultando o estudo da geologia local.

Apenas com o aumento das cotas, que se dā de modo geral de oeste para leste, é que o substrato cristalino começa a refletir-se nitidamente na geomorfologia, ao mesmo tempo que a drenagem se torna mais densa e sofre um pronunciado controle estrutural, quer pela gnaissificação e juntas quer por fenōmenos tectōnicos mais recentes. Assim, na faixa oeste da ārea, as altitudes variam de $600 \mathrm{~m}$, no Vale do Rio Mogi-Guaçu, a cerca de $700 \mathrm{~m}$, na altura da Fazenda Calunga, mais ao sul, com as maiores elevações à leste ostentadas pelas Serras dos Coutos e do Malheiro com altitudes mäximas de $1.000 \mathrm{~m}$ e a Serra do Matāo com $1.200 \mathrm{~m}$.

A configuração geral da topografia, a amplitude do relèvo e a altitude a que se elevam os morros são determinados pela natureza litolögica e pela situação relativa das superficies de aplainamento Itaguā e Japi, aliadas às deformações que elas so freram. Os altos topogräficos da região são representados princjpalmente pelos leitos mais ou menos possantes de rochas quartziticas, que ocorrem intercalados com as rochas gnäissicas e, subor dinamente, pelos gnaisses porfiroblāsticos e migmatíticos como a nordeste e sul do Bairro da Ponte Nova.

Em termos gerais, o relēvo exibe um nitido escalonamento positivo em forma de meia lua, segundo um eixo central na ārea no sentido de SSW para NNE, caracterizando movimentos tectönicos atuais que estariam afetando diretamente os blocos pela rea tivação das antigas falhas com orientação aproximada NNW-SSE. Este fato encontra apoio em Soares e Landim (1975), onde concluíram que toda a região nordeste do Estado de São Paulo e sul de Minas Gerais estā submetida a altas taxas de soerguimento com consequen
te basculamento dos blocos para norte.

Considerando-se a pequena dimensão da ärea focajizada, a orientação exibida pelas elevações ë bastante variävel.Na faixa oeste, embora de pequena expressão topogrāfica, as elevaçöes apresentam disposição geral N-S. Jä nas partes nordeste e leste da ärea, as saliēncias topogräficas, inicialmente com orien taçäo geral NNW, infletem para $N$ e finalmente para $N E \bar{a}$ medida que se caminha para a faixa milonitico-cataclästica de Jacutinga ao norte da ärea. Esta variação na orientação das elevaçōes ē nitidamente devida à rotação de blocos tectônicos ao longo dos pla- 
nos das principais falhas geolögicas que retalham a região.Ainda a Teste da cidade de Itapira, destaca-se na topografia o "nariz" da Estrutura Sinformal de Itapira, com seu traço axial aproximadamente $N 40 E$ e vergēncia para $S W$, modelado pela presença de possantes camadas de rochas quartziticas.

A rede de drenagem na região dos metamorfitos apresenta um forte condicionamento estrutural. Na ärea, ela $\bar{e}$ representada por dois rios principais: o Rio do Peixe e o Eleuterio, com sentido geral de escoamento NW, sendo ambos afluentes da margem esquerda do Rio Mogi-Guaçu. O Rio do Peixe, com um cur so caracterizado por certa variabilidade na sua orientação, encontra-se ora controlado pelas linhas de falhas com disposição NW-SE, ora pelas linhas de falhas NE-SW. Apresenta vale profundo e bem encaixado com algumas corredeiras, faltando depösitos aluvionares de monta atē a altura da Fazenda São Jerōnimo, a partir de onde passa a exibir vale chato e amplo, de natureza meândrica e com considerāvel quantidade de depōsito aluvial. Entre os afluentes de sua margem esquerda destaca-se o Ribeirão da Penha, que percorre a parte sul da ärea, com seu curso controlado basicamente pela foliação metamōrfica aproximadamente N-S,passan do a apresentar um trajeto mais irregular de leste da cidade de Itapira atē sua desembocadura, onde è controlado essencialmente por linhas de falhas. Outros afluentes menos expressivos, da mar gem esquerda de oeste para leste: os Cörregos da Fazenda Velha, da Agua Choca, dos Morais e, pela margem direita, os Cōrregos do Barreiro, 0legävio, do Recreio, dos Coutos, das Aguas Quentes e do Barracão. A densidade da drenagem ao sul do Rio do Peixe é pouco densa, irregular e, com exceção do Cörrego da Água Choca, não reflete um controle estrutural pronunciado, resultando no conjunto um padrão de natureza mais dendritica. Por outro lado, na parte norte a densidade da drenagem è alta, com forte condicionamento estrutural, padrão caracteristicamente retangular, com vales profundamente encaixados em forma de $V$ fechado e apresentando frequentemente corredeiras e pequenas cachoeiras como resultado do maior declive dos blocos.

O Rio Eleutërio que nasce ao norte das Serras do Malheiro e dos Coutos na parte nordeste da ārea, apresenta seu curso controlado basicamente pelas linhas de falhas com orientação NW-SE atē a altura do Vilarejo de Sapucaĩ, onde sofre uma in 
flexão para $W$, mantendo esta orientação atē deixar a ārea ao norte, apresentando neste trecho um curso perpendicular às estruturas e sō localmente paralelo. Os seus principais afluentes de prí meira ordem correm sempre concordantes com a orientação nordeste das estruturas. Estes afluentes se constituem em grandes calhas entre as serras, na porção norte da ärea, tambēm alinhadas na direção nordeste. Os afluentes de segunda ordem da drenagem principal, são perpendiculares ã orientação nordeste de seus coletores e são os responsāveis pelos intensos ravinamentos que rompem as encostas dos morros,produzindo no conjunto um padrão retangular muito nitido, que foi imposto pela estrutura.

Com relação aos depōsitos sedimentares cenozöicos, chamou-nos a atenção, o fato de, quando presentes, estando sempre situados no lado sul dos vales com disposição geral E-W. Neste sentido foi possivel notar uma nïtida relação entre estes depös tos e a forma topogräfica das encostas. Assim as encostas do lado sul dos vales exibem predominantemente terraços com inclinações suaves, favorecendo a preservação dos referidos depösitos, enquan to que do lado norte são ingremes, abruptos, normalmente nuas e com extensas exposições de rocha sã. Este fato vem confirmar, uma vez mais, as evidēncias de que movimentos tectōnicos atuais estariam afetando diferencialmente os blocos pela reativação das faThas antigas, provocando adernamento para $N$ ou NE, responsävel pe la epirogênese positiva que a região vem experimentando desde o Terciārio. Segundo o Professor Dr. J.M.V.Coutinho (informação ver ba1), esta relação dos depōsitos cenozōicos com as encostas situa das a sul dos vales, è uma constāncia em escala regional, sendo ob servadas em toda a regiäo norte e leste do Estado de São Paulo e sul de Minas Gerais.

A ocorrência de planícies aluvionares, são relativamente expressivas na parte centro-oeste da ārea. As principais situam-se ao longo de boa parte do Rio do Peixe e ao longo de toda extensão do Ribeirão da Penha (conforme mapa litolögico-estrutural anexo), que podem localmente atingir ate $1,5 \mathrm{~km}$ de largura. Caracterizam-se, estas ocorrências, por faixas extremamente planas, cobertas por vegetaçäo de pequeno porte, com rios meandran. tes e de tonalidades cinza escuro em fotografias aéreas. São cons tituidas por sedimentos recentes, assentados sobre o embasamento cristalino normalmente atravēs de fina camada de seixos. 


\section{DESCRIÇAO DAS LITOLOGIAS}

Os principais aspectos geolōgicos da ārea abordada, estão expressos no mapa litolögico-estrutural anexo, na escala $1: 50.000$. Não se acham representadas as esparsas ocorrências dos sedimentos neo-cenozóicos da Formação Rio Claro, que aparecem.geralmente capeando os interfiūvios.

De imediato ressaltam algumas āreas que constituem compartimentos litológicos estruturais perfeitamente caracterizados, ou seja, äreas correspondentes à ocorrēncia das rochas referĩveis à Bacia do Parană, à dos granitöides e à dos metamorfitos, sendo estes ültimos amplamente dominantes em extensão. Alēm da existência de depösitos recentes que ocorrem associados aos prin cipais vales.

\section{IV.1. Rochas Sedimentares}

Na região de Itapira, as rochas sedimentares da $\mathrm{Ba}-$ cia do Paranā acham-se pouco desenvolvidas e suas ocorrências 1ocalizam-se na parte $S W$ e $W$ da ārea estudada. São representadas por argilitos, siltitos e arenitos grosseiros a finos, localmente conglomeräticos. Estes podem ser observados na antiga estrada que liga Itapira a Mogi-Mirim, logo depois do contato com o cristalino. Segundo Soares et al. (1977), estas rochas devem ser referidas ao Subgrupo Itararē (do Grupo Tubarão), de idade Permo-Carbonifera. os raros afloramentos exibem mergulhos sub-horizontais, preferencialmente para oeste, apresentando-se pouco perturbados.

Estas rochas representam, na ārea em foco, uma delgada capa assentada sobre o embasamento cristalino. Isto pode ser constatado pelo fato da maioria dos leitos dos cursos d'ägua situaram-se em rochas cristalinas, e pela remoção da cobertura sedimentar afloram, nos lugares mais altos, rochas cristalinas circundadas por rochas sedimentares.

Ao lado dos sedimentos permo-carboniferos ocorrem tambëm, nas proximidades de Itapira, sedimentos neo-cenozóicos, re ferĩveis à Formação Rio Claro (Bjornberg e Landim, 1966a) capeando geralmente os interflüvios. Dada a sua pequena expressão geogräfica, estas rochas sedimentares não foram assinaladas na carta geolögica. 
Os sedimentos recentes ocorrem principalmente em extensas e alongadas planicies aluviais, acompanhando os princi pais cursos d'āgua da região em foco, e depōsitos de encostas;es tes $\bar{u} 1$ timos não foram mapeados.

Uma sucinta descrição destes tipos 1itolōgicos ē a presentada logo a seguir, no capitulo $\mathrm{V}$.

IV.2. Granitöides Cataclasados

Na ārea focalizada, estas rochas encontram-se restritas a uma ünica ocorrēncia na porção oeste, extendendo- se alēm dos limites $N$ e $W$ do mapa. Seu contato leste com as rochas metamörficas ē essencialmente tectōnico e a sudoeste :encontramse encobertas pelas rochas sedimentares da Bacia do Paranā.

A denominação de rochas granitöides cataclasados ē devida ao seu pronunciado estado cataclästico que mascara a natu reza granular tão característica para os granitos.

Aparentemente correspondem às rochas granitöides do Grupo Pinhal descritas por Wernick $(1972 b, c)$ e Wernick e Penalva (1980), de idade Brasiliana, e tambëm frequentemente encontradas na faixa milonitico-cataclästica de Jacutinga. Apesar do aspecto fortemente cataclästico, năo foram enquadradas na referida faixa milonitico-cataclästica pelo fato de estarem deslo cadas para sul em relação a mesma, e por constituirem um corpo relativamente homogēneo, com rochas essencialmente quartzo-felds päticas de granulação mëdia a grossa, revelando ainda sua nature za granitōide.

\section{IV.3. Rochas Metamörficas}

As rochas metamörficas, que foram o objetivo principal de nossos trabalhos, são as amplamente predominantes na ārea estudada. Os trabalhos de mapeamento, na região dos metamor fitos, permitiram a individualização das seguintes unidades ou associações litolögicas:

1. Cataclasitos e milonitos

Estas rochas são freqüentes ao longo das inūmeras falhas que retalham praticamente toda a região. Apresentam espes 
suras extremamente variāveis, desde submëtricas, a maioria, ate algumas dezenas de metros. Entretanto, podem atingir äreas consideräveis, como ē o caso da faixa com disposição geral NE-SW, situada a noroeste da ärea, onde constitui parte do sistema de falhamento de Jacutinga, cuja espessura local atinge cerca de $3 \mathrm{~km}$. Estas rochas cataclästicas e minolīticas são representadas por litologias regionais que sofreram intenso ...metamorfismo dinämico, resultando num maior ou menor grau de fraturamento e moagem. As falhas que afetaram tanto os granitöides do Grupo Pinhal como as demais litologias são referiveis à fase final do Ciclo Brasiliano (Rodrigues, 1976; Wernick et al., 1976b).

No mapa litolögico-estrutural anexo, estão representadas, como unidades individuais, apenas a faixa correspondente ã zona de falhamento de Jacutinga à NW da ärea e uma menos expressiva ao norte da Usina Nossa Senhora Aparecida, com orientação NNE-SSW.

\section{Rochas metamōrficas de baixo grau}

Correspondem a uma sequência metassedimentar anqüimetamörfica, referīvel à Formação Eleutērio de Ebert (1971) que ocupa, na ārea investigada, uma faixa de aproximadamente $5 \times 1 \mathrm{~km}$. Estā embutida tectonicamente entre as rochas miloniti zadas da falha de Jacutinga, ao norte, e as rochas metamōrficas de grau muito mais elevado, ao sul.

3. Rochas metamōrficas de mëdio a alto grau

Dentro das rochas metamörficas de mëdio a alto grau, foram passĩveis de caracterização as seguintes associaçöes litolögicas:

Associação Litolōgica - A

(Biotita elou hornblenda gnaisses e biotita xistos com intercalações de anfibolitos e gonditos - $\mathrm{BH}_{9} \mathrm{~A}$ )

Essa associação litolögica ocorre em compartimentos com distribuição mais ou menos alinhados que corresponde aproximadamente a uma faixa central, abrangendo quase toda a ex- 
tensão da ärea, com disposição geral NE-SW. Trata-se de uma unidade bastante homogênea, tendo como principais representantes o biotita e o hornblenda gnaisses, que ocorrem em quantidades apro ximadamente equivalentes ao sul, e predominando ligeiramente o biotita gnaisse ao norte da ārea. O biotita xisto, embora sempre presente constituindo camadas, leitos ou bandas com espessu ras mētricas e submëtricas, ë pouco expressivo em relação às duas outras litologias. Os contatos entre as rochas acima refer das são essencialmente transicionais.

As intercalações anfiboliticas são de dimensões muito variāveis, desde pouco decímetros a algumas dezenas de metros de largura, e estendem-se por atē värias centenas de metros. São geralmente concordantes ou levemente discordantes com os gnaisses, com os quais exibem contatos bruscos. A concentração dos anfibolitos, nesta unidade, è muito variāvel. Assim, são bastante frequentes no compartimento situado ao sul da ārea, tor nando-se cada vez mais raros a medida que caminharmos para os compartimentos localizados mais ao norte. Quanto aos gonditos,apresentam sua maior concentração exatamente nesta unidade, onde constituem corpos lenticulares de dimensões centimētricas e mais raramente submētricas, associados a fäcies gnäissicas mais quartzosas. Estão basicamente limitados ao terço sul deste conjunto.

Esta associação litolōgica apresenta-se, de modo geral, como uma das mais intensamente afetadas pelos agentes intempēricos, com espesso manto de regolito.

Associação Litolögica-B

(Biotita e/ou hornblenda gnaisses com intercalações de quartzitos variados, biotita xistos, anfibolitos, biotita gnaisses porfiroblāsticos, gnaisses graniticos e raros gonditos - BHgP)

Dentre as värias associações, esta è, sem dūvida,a que apresenta maior variedade litolögica. Ocorre constituindo grosseiramente duas faixas irregulares com disposição geral NESW bordejando praticamente toda a associação litolōgica anterior. Embora seu arcabouço rochoso seja representado por uma as- 
sociação intima entre o biotita e o hornblenda gnaisse, com conmina largamente sobre o segundo.

Entre as intercalações, as de quartzitos variados com espessuras que vão desde decimētricas a vārias dezenas de metros, são os mais frequlentes, estando presentes em toda a unidade. Contudo, sua concentração diminui gradativamente de noroeste para sudeste. Jā os gonditos são um tanto raros, estando limitados na porção centro-sul constituindo diminutos corpos lenticulares associados principalmente aos leitos quartziticos.

As intercalações de anfibolitos apresentam basicamente as mesmas caracteristicas descritas na associação litolögica anterior. Sua frequéncia parece diminuir tanto para norte quan to para oeste. Por outro lado, os biotita gnaisses porfiroblästicos e os gnaisses graniticos apresentam distribuição mais ou menos homogēnea por toda a unidade, com espessuras mäximas de pou-
cas dezenas de metros.

Os contatos das intercalações com as rochas constituem o arcabouço são essencialmente gradacionais, exceto nos biotita gnaisses porfiroblästicos e nos anfibolitos, que são normalmente abruptos mas concordantes com as mesmas.

Associação Litolögica - C

Quartzitos variados associados com biotita e/ou hornblenda gnaisses, biotita xistos, anfibolitos e gonditos - Q)

ocorre constituindo tanto faixas continuas, como na parte NW da ärea, quanto corpos alongados de dimensões variāveis, na maioria das vezes ondulados ou dobrados. A leste de Itapira ocorre um espesso pacote arqueado representando o "nariz" de um grande sinforme. Esta associação pode apresentar-se tanto de forma isolada, como as ocorrēncias a NW da ärea e no "nariz" do referido sinforme, quanto englobada por outras associações litolo gicas, refletindo possivveis variações faciolögicas do material prē-metamörfico. Como pode ser notado na carta geolögica, esta unidade decresce em dimensão e frequencia de oeste para leste. 
E composta por intercalações de quartzitos com bio tita e hornblenda gnaisses, contendo leitos ou lentes de biotita xistos, gonditos e anfibolitos. Embora os quartzitos tenham sido realçados na associação litolögica, os gnaisses o superam em quantidades. Pudemos notar, em vārias secções perpendiculares às estruturas das rochas, um comportamento bastante homogēneo com relação à distribuição destas litologias dentro da associação,re velando, de forma mais ou menos constante, uma certa ritmicida de. Assim, em uma secção realizada imediatamente ao sul de Itap ra, esta associação litolögica mostra esquematicamente a seguinte distribuição:

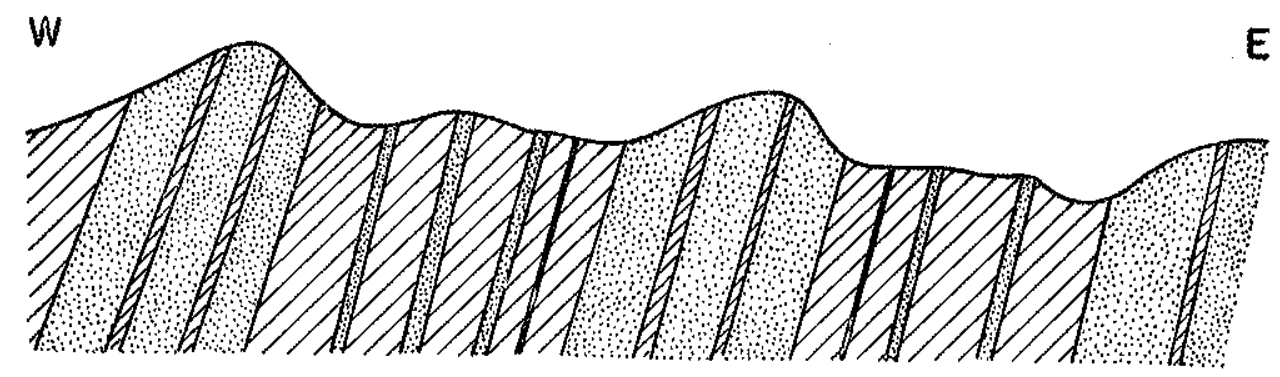

LEGENDA

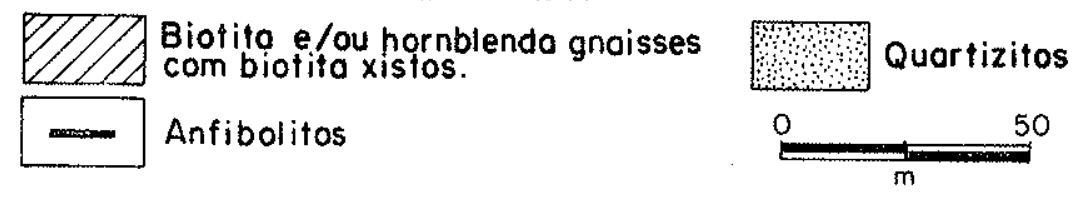

Nestas intercalações, que persistem em toda a şeccão, ora predominam os quartzitos com leitos delgados de gnaisses ou biotita xistos, ora os gnaisses com biotita xistos, anfibolitos e leitos delgados de quartzitos. A ritmicidade parece ser uma constante para todos os corpos desta associação, variando, no entanto, as espessuras que podem atingir no māximo uma centena de metros.

A maior concentração de anfibolitos ocorre no paco te situado junto à sinclinal, a leste de Itapira, sendo relativa mente raros nos demais. 0 biotita xisto apresenta-se pouco desen volvido em toda a unidade.

os gonditos, sob forma de diminutas lentes, são re lativamente frequentes nos corpos da associação litolögica localizada na metade inferior da ārea, principalmente a oeste. 
(Biotita gnaisses com intercalações frequentes de quart zitos variados,biotita xistos e gonditos - BgQ)

Corresponde a uma faixa com disposição N-S, na parte oeste da ärea. Grande parte estā em contato com as rochas sedimentares da Bacia do Paranā. E representada basicamente pelo biotita gnaisse com a presença freqüente de camadas, leitos ou lentes de quartzitos puros e impuros distribuidos heterogeneamente por toda a unidade. Os biotita xistos, embora frequentes, formam leitos de espessuras reduzidas e são pouco expressivos. Os gonditos são comuns a NW de Itapira, quase sempre constituindo mi núsculos leitos associados aos quartzitos.

Associação Litolögica - E

(Biotita gnaisses com intercalações de anfibolitos biotita xistos - BgX)

Estä restrita à extremidade NE da ärea. E constitu da essencialmente por biotita gnaisses com concentrações, em värios locais, de intercalações de biotita xistos localmente enriquecidos em hornblenda. Estas concentrações representam vārios leitos, mais ou menos continuos, com espessuras desde submētricas até uma ou duas dezenas de metros, separados concordantemente pelos biotita gnaisses com os quais exibem contatos tanto gradacionais quanto abruptos.

0s anfibolitos tem relativa frequência na parte les te da unidade, constituĩndo dimensões reduzidas e sō muito raramente, como a SE da Fazenda do Bom Cafē, podem chegar a uma dezena de metros de espessura. São concordantes ou levemente discordantes com o biotita gnaisse, apresentando, com estes, contatos abruptos.

Associação Litolögica-F

(Gnaisses pegmatiticos)

Trata-se do gnaisse regional com granulação mais grossa que o normal, apresentando faixas continuas ou descontínuas, bolsões ovalados, nödulos e concreções constituĩdas pela 
concentração principalmente de feldspatos e quartzo de granulação grossa. Estas concentrações conferem uma textura pegmatĩtica às rochas. Distribuem-se irregularmente acompanhando a foliação geral das rochas gnäissicas regionais, com as quais exibem contatos normalmente dirusos pela gradual redução no tamanho dos grãos.

Suas principais ocorrências situam-se nos arredores da Fazenda Fortaleza, a E da ārea, e na margem esquerda do Rio do Peixe, a NE da fazenda São Jerónimo, estando alojados ras associações litolögicas (B) e (L).

Associação Litolōgica-G

$$
\text { (Biotita } \pm \text { granada xistos - BX) }
$$

Estas rochas foram passiveis de serem mapeadas nas partes $E$ e SE da ārea. Constituem corpos aparentemente homogēneos, que se encontram profundamente afetados pelos agentes intempēricos, desenvolvendo espessos mantos de regolito, dificultarido sobremaneira seu detalhamento. O corpo localizado a NE da Fazenda São Luiz e portador de granadas que podem atingir ate $1 \mathrm{~cm}$ de dia Associação Litolögica-H

(Hornblenda gnaisses e anfibolitos - HgA)

Esta associação litolögica estä restrita a duas ocorrēncias na rodovia Itapira-Lindöia, prōximo à margem esquerda do Rio do Peixe, e uma menor, ao sul da mesma rodovia, na margem esquerda do Ribeirão da Penha. De um modo geral $0 .$. hornblenda gnaisse, que $\bar{e}$ a litologia predominante, gradaciona para corpos anfiboliticos de estrutura xistosa a compacta. Na ocorrēncia cortada pela rodovia, o corpo anfibolitico atinge cerca de $100 \mathrm{~m}$ de espessura e se dispõe concordantemente às estruturas do hornblenda gnaisse envolvente. Nas duas outras ocorrēncias, os anfiboli tos constituem lentes ou camadas concordantes ou levemente discor 
(Gonditos - G)

Os gonditos apresentam alguns horizontes individua lizados a SE de Itapira, embutidos em biotita gnaisses, e a NW da mesma cidade, encaixados em muscovita quartzitos e biotita gnaisses. Estes corpos são geralmente constituĩdos por vārios ho rizontes ou camadas, chegando alguns deles a atingir at $\bar{e} ; 0 \mathrm{~m}$ de espessura, intercaiados com suas rochas encaixantes. Os contatos entre os horizontes de gonditos e as rochas encaixantes são pre-
dominantemente gradacionais.

Associação Litolögica-J (Märmores calcäticos com intercalações de biotita xis-
tos - CC)

Encontra-se restrita a duas ocorrências: uma na Fazenda da Fortaleza, a mais expressiva, e a outra na divisa dos Estados de São Paulo e Minas Gerais, ambas a E da ārea. Os märmores apresentam-se alternados com leitos mëtricos de biotita xistos, com os quais exibem contatos abruptos.

Associação Litolōgica-K

(Meta-hornblenditos e meta-ultramafitos - HU)

concentrações de corpos de meta-horno litolögica estā representada por tos embutidos nos gnaisses. como discordantes, geralmente constituem corpos tanto concordantes riāveis, desde poucos decĩmetros tabulares, com dimensões muito vade espessura e podendo estender-se por mais de tros. Apresentam contatos bruscos em relacão uma centena de me nais.

Os meta-hornblenditos são muito mais frequentes. As maiores concentrações de meta-ultramafitos ocorrem a $W$ da Fazen- 
(Biotita gnaisses e gnaisses graniticos - BgG)

Trata-se de uma associação bastante homogēneo loca lizada a SE da ärea. Embora as duas litologias ocorram associadas, os gnaisses graniticos são mais comuns ao longo da faixa situada mais a oeste. 0 biotita gnaisse, normalmente mais pobre em mäficos que o normal, ainda è a litologia predominante, exibindo, com o anterior, contatos predominantemente transicionais e poucas vezes abruptos, mas sempre concordantes entre si.

Associação Litolögica - M

(Gnaisses graniticos com intercalações de biotita e/ou hornblenda gnaisses - $G G$ )

Estā representada por duas ocorrēncias situadas a NW e NE da ārea, compostas essencialmente pelos gnaisses graniti cos com aleatörias intercalações de biotita e hornblenda gnaisses exibindo poucas dezenas de metros de espessura. 0s contatos entre estas litologias são tanto gradacionais quanto abruptos.

Associação Litológica - N (Biotita e/ou hornblenda gnaisses anatexiticos e migma
titicos - AM)

Apresenta um corpo com forma ligeiramente ovalada, na extremidade SE da ārea. E constituĩdo pelos biotita e hornblenda gnaisses regionais que, pelo inicio e aumento de mobiliza cão dos leitos claros, passam progressivamente a gnaisses anatexiticos, constituídos de leucossoma quartzo-feldspätico e melanossoma rico em biotita e hornblenda. 0 processo $\bar{e}$ acompanhado pelo desenvolvimento de estruturas migmatiticas. Ainda nas partes central e sul do referido corpo, estes biotita e hornblenda gnaisses anatexiticos apresentam nūcleos que sofreram infiltração de material granitico mais novo, caracterizando a migmatização . 
(Biotita e/ou hornblenda gnaisses porfiroblästicos com intercalações de gnaisses não porfiroblästicos - BgP)

Representa äreas de major concentração de biatita e hornblenda gnaisses porfiroblāsticos, cujas principais ocorrēn cias situam-se na parte leste da ärea estudada. Associados a estes, ocorrem intercalações de biotita e hornblenda gnaisses, além de gnaisses graniticos, isentos de megacristais. A predominância entre um e outro tipo è de difĭcil determinação, devido principalmente ao intemperismo pronunciado e à configuração mujto acidentada do relevo, o que tornam estes locais de difícil acesso. Contudo, ainda parecem predominar os gnaisses desprovidos de megacristais. A passagem dos gnaisses porfiroblästicos para os não porfiroblāsticos se dā normalmente de forma abrupta e, em poucos casos, se processa por uma redução na sua intensidade atë o desaparecimento total.

os contatos entre as diversas associações litolögi cas supra descritas podem ser tectōnicos, gradacionais e, mais raramente, abruptos. Os primeiros são predominantes principalmen te no terço norte da ärea a medida que se aproxima da zona de fa Thamento transcorrente de Jacutinga.

As associações litolögicas de "A" atē "K" são aqui consideradas como sendo totalmente referíveis ao Grupo ... Amparo, por serem constituĩdas de seqüencias nitidamente meta-sedimentares ao lado de quantidades variāveis de corpos meta-ĭgneos bāsi. cos e ultramäficos associados, conforme descritas por Wernick (1967, 1972c, 1978a,b), Fiori (1979) e Fiori et a1. (1978,1980).

As associações litolögicas de "L até 0 ", que predó minam na parte $S E$ da ārea mapeada, foram referidas, tentativamen te, ao Embasamento do Grupo Amparo. A atribuição destas 1itologias ao Arqueano baseou-se principalmente nas seguintes evidēncias: ausência de sequencias nitidamente reconheciveis como sendo meta-sedimentares; deformações mais complexas, com as rochas exibindo frequentemente texturas do tipo "fluidal", e pelo supor te geocronolögico (capitulo VII). Estas considerações coadunam se com as descritas por Fiori (1979) e Fiori et al. (1979,1980).

Na associação litolögica "N" afloram nūcleos migma 
tîticos de idade brasiliana (capitulo VII) enquadrāveis no Grupo Pinhal.

0 padrão estrutural destas associações ē complexo, com evidências de dobramentos, redobramentos e transposições. As direções estruturais, cọo podem ser observados no mapa litológ co-estrutural anexo, apresentam a oeste de Itapira, direções pre dominantemente $\mathrm{N}-\mathrm{S}$ e, a leste da mesma, uma estrutura sinclinal com disposição geral NE-SW. A leste da ārea, as direções estrutu rais evidenciam tendências para N-NW, flexionando gradativamente para $N$ e posteriormente NE a medida que se caminha para norte, re fletindo a disposição geral apresentada pelos grandes alinhamentos tectônicos da faixa de transcorrēncia de Jacutinga. A gnaissificação apresenta mergulhos acentuados, quase sempre superiores a 450, principalmente para W e NW, com variações para SW.

Em capitulos subsequentes serão tratadas mais deta Thadamente as características petrogräficas e estruturais da ărea mapeada, tendo sido dada especial atenção aos metamorfitos. 


\section{PETROGRAFIA}

\section{V.1. Rochas Sedimentares}

As rochas sedimentares da região abordada concentram-se principalmente na sua parte $S W$ e $W$, e os sedimentos incon solidados ao longo dos principais cursos d'ägua. Estão presentes tanto rochas permo-carbonīferas quanto neo-cenozōicas, caracterizando-se as pós-permianas por seu estado mais ou menos inconsolidado.

\section{V.1.1. Rochas sedimentares do Grupo Tubarão (permo-carbo- niferas)}

Ocupam uma faixa a SW e $W$ da ārea mapeada, e constituem, no campo, afloramentos tênues de argilitos, siltitos e arenitos localmente conglomeräticos, aparentemente cinza claro,po rëm, com predomināncia das cores amareladas e avermelhadas resultantes do intemperismo. os arenitos, constituem a litologia predo minante, sendo de granulação mēdia a fina, geralmente friāveis, predominando os tipos de regular seleção. Localmente são levemente conglomeráticos, resultando num aspecto mais grosseiro. Tanto os conglomeräticos quanto aos demais arenitos são quartzosos, com grãos subangulares a angulares, constituídos por matriz argilosa e exibindo, de modo geral, discreta estratificação plano-paralela. Os argilitos e siltitos foram encontrados ao sul da Fazenda Calunga, situada na parte $S W$ da ärea. Ocorrem intercalados nos arenitos na forma de delgadas lentes de aspectos maciços ou com incipiente laminação.

As rochas sedimentares constituem, em seu conjunto, um pacote pouco perturbado que mergulha suavemente para o interior da Bacia do Parană. E característica a descontinuidade destas rochas junto ao contato com o embasamento cristalino, jā que a erosão tende a exumar cada vez mais o assoalho prē-glacial.

V.1.2. Rochas sedimentares da Formação Rio Claro (neo-cenozöico) 
As poucas ocorrências encontram-se na parte ociden tal da ārea estudada, capeando as rochas sedimentares do Gnupo Tubarão onde ocupam geralmente os interflūvios, e a $N$ e $N E$ da Cidade de Itapira, $j \bar{a}$ no cristalino, principalmente em terraços do Rio do Peixe. São depösitos incipientemente consolidados, cons tituidos principalmente por areias, cascalhos e argilas, pobres em estruturas sedimentares e apresentando geralmente rāpidas mudanças litolögicas no sentido vertical bem como normalmente baixo grau de seleção. E comum ocorrer, na base destes depósitos, uma linha de seixos que, localmente, pode ampliar-se para pequenas cascalheiras de atë um metro. São ruditos mal selecionados, constituidos por seixos pouco rolados, angulares a subangulares e de composição variāvel de acordo com sua localização geogrāfica. Assim, por exemplo, em uma das melhores exposições situada na rodovia Itapira-Jacutinga, prōximo ao Rio do Peixe, estes sej xos são de quartzo de vieiro, bem como de quartzitos, muscovita quartzitos e mesmo de biotita gnaisses, demonstrando indubita velmente, serem oriundas das rochas circunvizinhas. Esta relação pode ser constatada em värios depösitos desta natureza situados tanto na ārea cristalina quanto na ärea das rochas sedimentares permo-carboniferas, denotando, desta forma, que as fontes destes depösitos são as pröprias rochas ocorrentes nas suas vizinhanças. Os depösitos neo-cenozöicos foram estudados por värios autores (Bjornberg, 1965, 1969; Bjornberg e Landim,1966a, 1966b; Penalva, 1964; Melfi et a1. 1966; Christofoletti e Queiroz Neto, 1966; Carvalho et a1. 1967; Penteado, 1969), quanto às suas caracteristicas mineralögicas, granulomëtricas e pedológi-
cas.

A origem dos sedimentos neo-cenozóicos tem sido ad mitida pela maioria dos autores acima referidos como sendo pedimentar, se bem que Fülfaro e Suguio (1968) Thes atribuem origem ligada a causas tectónicas.

\section{V.1.3. Sedimentos recentes}

Os sedimentos recentes correspondem a depỏsitos atuais dos cursos d'ägua e aos coluviais. Os primeiros são expres sivos ao longo da major extensão do Rio do peixe e em todo percurso do Ribeirão da Penha. Acham-se embutidos em uma ārea rela- 
tivamente plana, sem grandes expressões topogräficas, constituindo extensas e alongadas planĩcies aluviais. Säo

representados principalmente por argila e areias de grã mëdia a grosseira, com certas quantidades de matēria orgānica, resultando, no conjunto, a predominância de cor cinza-escura. Em äreas de relevo mais pronunciado, são frequentes os nïveis conglomerāticos lenticulares, constituídos por seixos angulares e heterogêneos, tendo como fonte as rochas circunvizinhas. Esses sedimentos são ricos em estruturas lenticulares, de corte e preenchimento, e exibem a $a ̈ p i d a s$ mudanças litolögicas no sentido vertical.

Os depōsitos coluviais são resultantes principalmen te de ação da gravidade, e estão associados a fases de dissecação das encostas e acümulo nos sopës das vertentes com elevado suprimento de clästicos. Embora estes sedimentos sejam frequlentes em toda a ārea, não foram mapeados devido às pequenas expressões geo gräficas que apresentam.

\section{V.2. Granitöides Cataclasados}

Generalidades

Essas rochas são idênticas aos granitōides cảtaclās ticos encontrados na zona de falhamento de Jacutinga. Ambos são considerados como pertencentes ao Grupo Pinhal. Foram mapeadas co mo um tipo litolögico a parte pelo fato de estarem aparentemente deslocadas para sul em relação à zona de falhamento de Jacutinga, e pela homogeneidade composicjonal granitica da rocha afetada.

0correm nas imediações do Rio Mogi-Guaçu, na altura da sua confluência com o Rio do Peixe, a oeste da ärea, desaparecendo logo ao sul sob as rochas sedimentares da Bacia do paranā. Constitui, no local, uma ārea muito plana, intensamente intemperi zada e totalmente cultivada, sendo muito pobre em afloramentos.

Trata-se de uma faixa com direções estruturais de dificil determinação por serem os afloramentos constituidos prati camente só por blocos. Pela fotointerpretação parecem predominar as com orientação NNE-SSW com variações para N-S, o que representaria um certo ângulo entre as suas direções estruturais e as da zona de falhamento de Jacutinga localizada mais a NE da ärea. 


\section{Descrição}

São rochas de composição granïtica, com cores rosa das e aspecto foliado. Exibem amplas variações estruturais e tex turais que refletem o maior ou menor efeito da cataclase. Aflora mentos constituídos por milonitos e ultramilonitos são extremamente raros nesta faixa, sendo observados praticamente apenas ca taclasitos. Estes são constituídos por leitos ou agregados minerais lentiformes, pouco afetados, envolvidos por uma massa cataclāstica muito fina, (Foto 1 ).



Foto 1 - Granitōide cataclasado. Margem esquerda do Cōrrego da Fazenda Velha, prōximo à sua confluência com o Rio Mogi Guaçu.

A textura predominante destes granitóides cataclās ticos é tanto do tipo mortar quanto do flaser. Os agregados mine rais são constituïdos principalmente por feldspatos, predominando entre estes o microclīnio, e subordinadamente o quartzo. Todos estes minerais apresentam sinais dos efeitos cataclāsticos, tais como: microfraturamento, extinção ondulante e planos de geminação deformados. 0 microclīnio é pertītico e inclui frequente 
mente grãos de plagioclāsio sericitizados. E possivel que a persistência dos feldspatos se relacione com a prōpria heterogeneidade da granulação das rochas cristalinas (granitos porfirōides).: As texturas porfiröides podem ter influido no desenvolvimento dos cataclasitos e milonitos, favorecendo a maior preservação dos feldspatos.

A massa cataclästica que cimenta os agregados de cristais parcialmente fraturados e deformados, ē predominantemen te quartzo-feldspätica e parcialmente recristalizada. Nestes lei tos se concentram os mäficos, representados dominantemente por hornblenda, seguida pela biotita, clorita e epidoto. A.hornb.lenda apresenta grãos irregulares, quebradiços, intimamente associada à biotita, clorita e epĩdoto, com os quais constitui um intercrescimento emaranhado com contatos quase sempre difusos. A bioti ta, bastante cloritizada, apresenta-se com lamelas deformadas, con torcidas e, muitas vezes, em fiapos irregulares finamente esfare lado.0 epidoto, quase sempre, formado às custas do plagioclāsio e da hornblenda, ocorre sob a forma de pequenos cristais irregulares, ameböides.e, por vezes, como ramificações tambëm irregula res.

Os acessórios são representados pelos opacos, que se encontram pulverizados, cristais de titania fraturados e disseminados associados à hornblenda, a lēm de grãos arredondados de apatita e raros cristais de granada fragmentados.

\section{Considerações Finais}

Embora estes granitōides cataclasados sejam muito semelhantes aos encontrados em grande parte do falhamento de Jacutinga, chama a atenção o fato de sua localização ser um pouco mais ao sul, refletindo um leve deslocamento em relação ao alinhamento geral do referido fathamento. Este fato poderia represen tar uma inflexão mais ou menos pronunciada para o sul, da zona de falhamento de Jacutinga, ou um deslocamento de suas rochas cataclasadas por meio de movimentos ao longo de planos de falhas pos teriores, que truncariam suas estruturas. Uma outra explicação,tal vez mais remota, poderia ser dada em termos de uma bifurcação da zona de falhamento principal. Entretanto, para se esclarecer este fenōmeno, são necessārios estudos mais detalhados das rochas e suas relações estruturais envolvendo uma faixa adicional ao nor- 
te da ärea mapeada.

\section{V.3. Rochas Metamörficas}

As diferentes litologias metamörficas foram definidas utilizando critērios mineralögicos e estruturais, tanto no campo quanto em lāminas delgadas. Embora na ārea de domīnio dos metamorfitos, como ficou evidenciado no capitulo precedente,ocorram āreas que constituem compartimentos litolögicos estruturais perfeitamente caracterizados, tais como as ocupadas pelos gnaisses, e outras menores de migmatitos e de metassedimentos anquimetamōrficos, refletindo condições genëticas diversas, elas serão tratadas conjuntamente em um mesmo subcapitulo.

Pela prōpria sistemätica de mapeamento, isto $\bar{e}$, em unidades constituĩdas por diferentes associaçöes litolögicas, um mesmo tipo litolögico pode ocorrer em duas ou mais unidades diferentes. Desta forma, a descrição serā efetuada por tipos litolögi cos, na seguinte sequência:

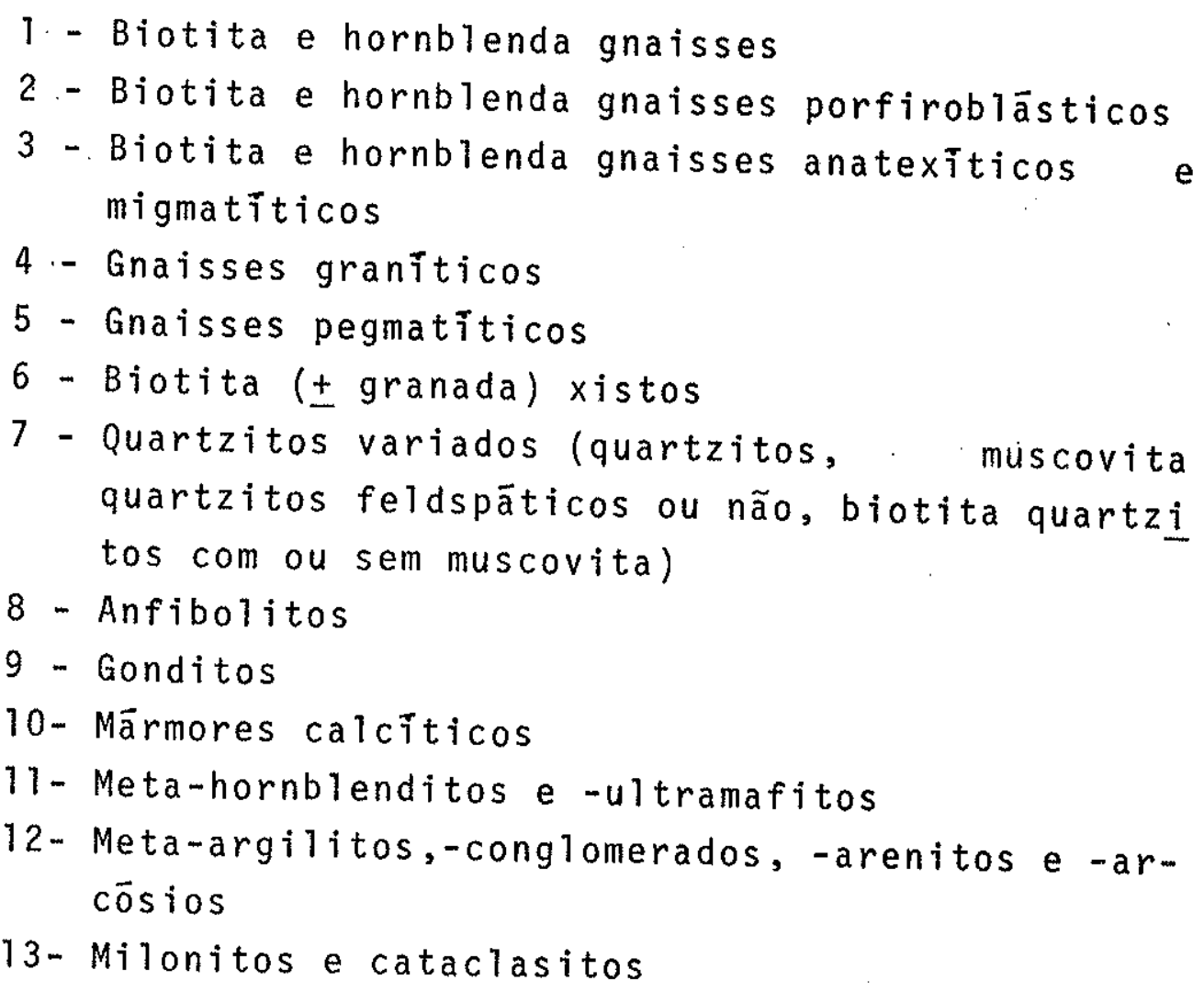

1. Biotita e hornblenda gnaisses

Constituem a litologia mais freqüente da ārea foca 
lizada, com o biotita gnaisse predominando amplamente sobre o hornblenda gnaisse. A descrição conjunta destes dois tipos 1ito10̈gicos deve-se ao fato de o segundo ocorrer quase sempre intima mente associado ao primeiro, constituindo intercalações contjnuas ou não, na forma de camadas, leitos ou lentes, de espessuras geralmente reduzidas, mas de forma persistente.

As intercalações de hornblenda gnaisses são frequentes na faixa central a leste de Itapira, com disposição NNESSW, representada pela unidade constituida pelo biotita: e/ou hornblenda gnaisses e biotita xistos com intercalações de anfibo litos e gonditos, estando praticamente ausente na borda oeste da ārea em contato com a Bacia do Paranā. Tambēm decresce gradualmente para leste. As melhores exposições desse gnaisse são encontradas numa pedreira abandonada pröximo à margem : esquerda do Rio do Peixe, a leste da rodovia Itapira-Jacutinga, bem como no $\mathrm{km} 35,3$ da rodovia Itapira-Lindóia, e ao sul desta mesma rodo via entre a Fazenda do Jardim e o Cörrego do Bom Retiro.

Jä o biotita gnaisse, como pode ser visto na carta geolögica anexa, estā presente em quase todas as unidades e normalmente constitui a litologia predominante. Suas melhores exposições localizam-se a sudeste da ärea nas proximidades da Serra das Aguas Claras, no Rio do Peixe, ao sul do Bairro Ponte Preta, e nas proximidades da Fazenda da Fortaleza.

\section{Estruturas}

Estas rochas exibem, de modo geral, estrutura gnäis sica nitida, caracterizada por uma alternāncia de leitos claros e escuros, geralmente persistentes ao nivel de afloramento, e que resultam, no conjunto, em estruturas bandadas, fitadas ou listradas (Foto 2 e 3 ). Macroscopicamente, os leitos escuros são cinza esverdeados a verde acastanhados e os claros são cinza esbranquiçados. Por intemperismo as rochas adquirem cores castanho avermelhadas ou castanho-amareladas a esverdeadas.

A alternāncia dos leitos claros e escuros apresen ta composição e passagens variadas, que podem ser resumidos da seguinte forma:

- Os leitos e bancos são persistentes no sentido 


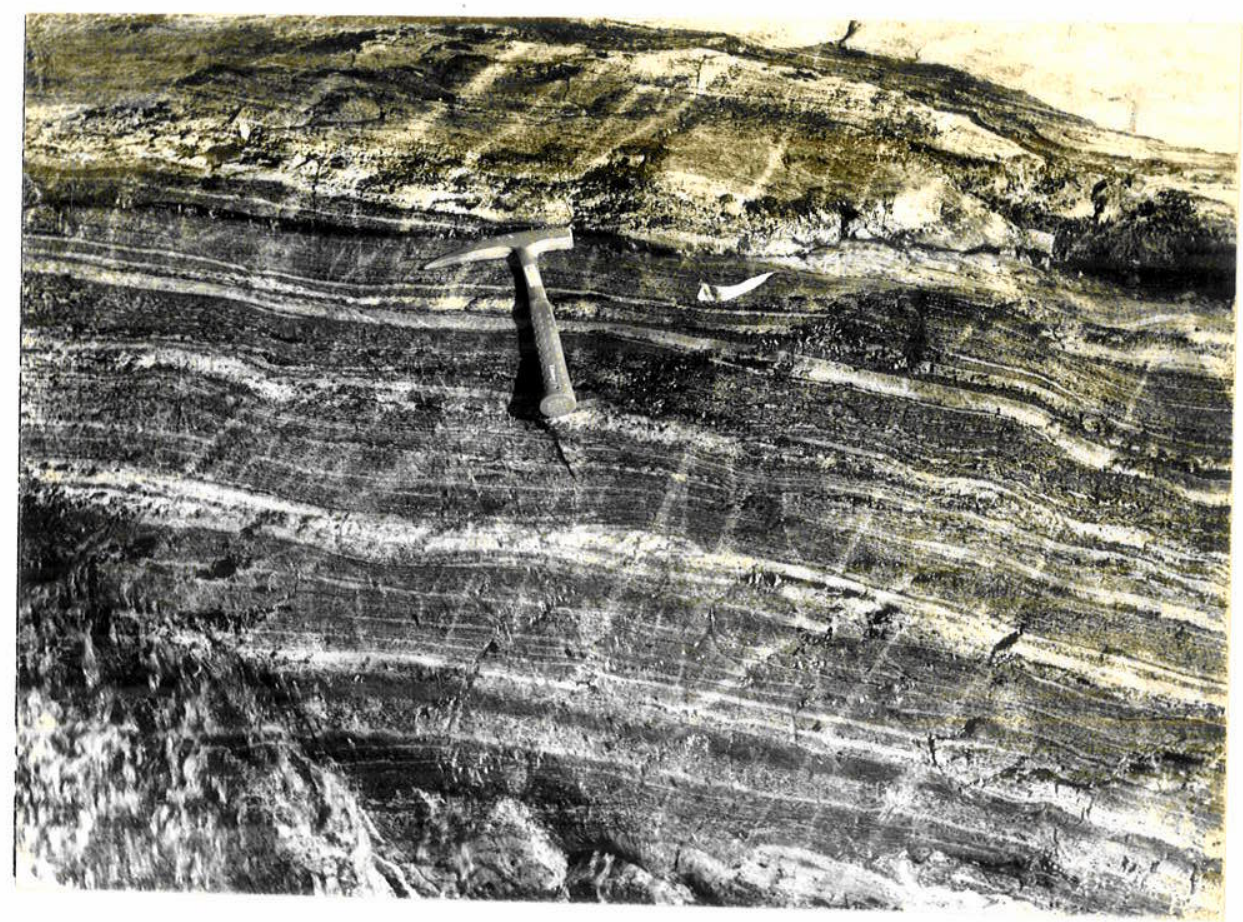

Foto 2 - Biotita hornblenda gnaisse bandeado a fitado. Fazenda do Matão.

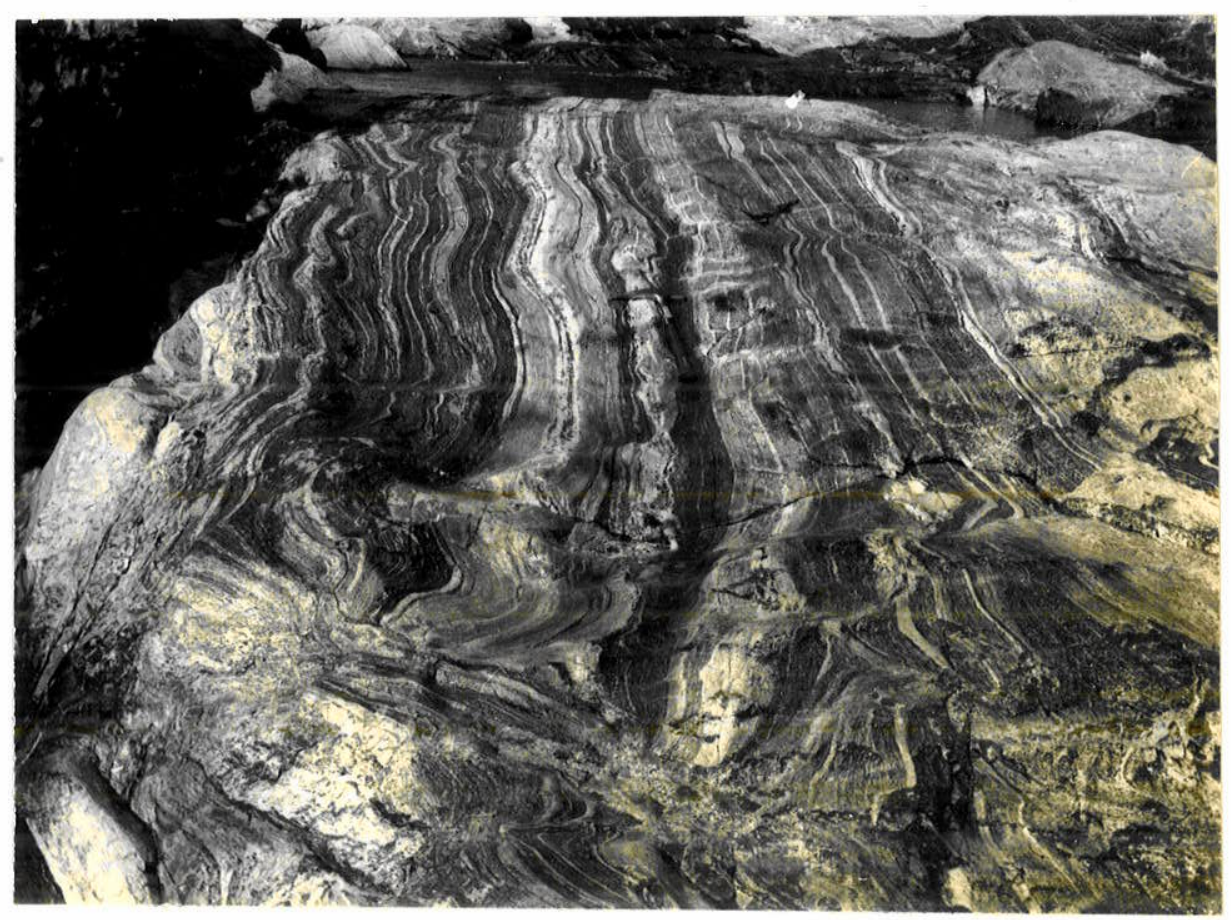

Foto 3 - Biotita gnaisse bandeado.Cōrrego da Cristāitia a oeste da Fazenda Cristālia. 
da direção da foliação e os contatos entre eles se caracterizam por passagens gradativas. A composição e granulação das rochas e. variāvel ocorrendo entre os leitos claros ora rochas onde quartzo e o mineral siālico predominante, ora rochas onde 0 feldspato ē o mineral essencial. Os lejtos escuros tambēm são de composição muito variāvel, sucedendo-se rochas de indice de colo ração variāvel assim como rochas portadoras sō de biotita, biotí ta e hornblenda, hornblenda, alēm de outras associações destes minerais com granada, epidoto, diopsidio, etc., como minerais co loridos. E comum, num mesmo corpo rochoso, a alternäncia de leitos escuros, portadores sō de biotita ou sō de hornblenda, com leitos intermediarios transicionais compostos pelos dois minerais, separados pelos leitos quartzo-feldspaticos.

- A alternāncia entre leitos claros e escuros $\bar{e}$ feito por intercalações de composição anfibolitica, exibindo con tatos bruscos. A granulação e a composição dos leitos escuros são homogêneos e estão representada por andesina anfibolitos de grã mēdia.

- Os leitos são mais finos e menos persistentes, ob servando-se nitidamente, nos afloramentos, um aumento do indice de coloração dos leitos escuros pela segregação dos minerais sia licos, que constituem camadas de aspecto aplitico e pegmatitico, e que se caracterizam, ao conträrio dos primeiros, por apresentar uma textura ligeiramente pegmatiticas.

\section{Texturas}

De um modo geral, predomina amplamente a textura granoblästica mais ou menos cataclästica e apenas em rochas de alto indice de coloração ocorrem texturas lepidoblásticas e nema toblästicas, restritas a leitos milimëtricos que se alternam com leitos de textura granoblästica.

Em quase todas as amostras, hã evidēncias de efeitos cataclästicos de grau variāvel, com recristalizaçäo. Essas e vidências acham-se representadas por deformações, fraturamentos e microgranulação, principalmente dos grãos de quartzo e feldspa tos. E frequente a ocorrēncia de textura blastomilonitica com leitos microdobrados, indicando que a recristalização foi acompa nhada de forte deformação tectōnica, tendo aquela superado esta. 
A elevada plasticidade atingida por estas rochas, durante a defor mação, pode ser evidenciada pelo desenvolvimento de textura "flui dal" presente nas rochas mais afetadas (Microfoto 1).

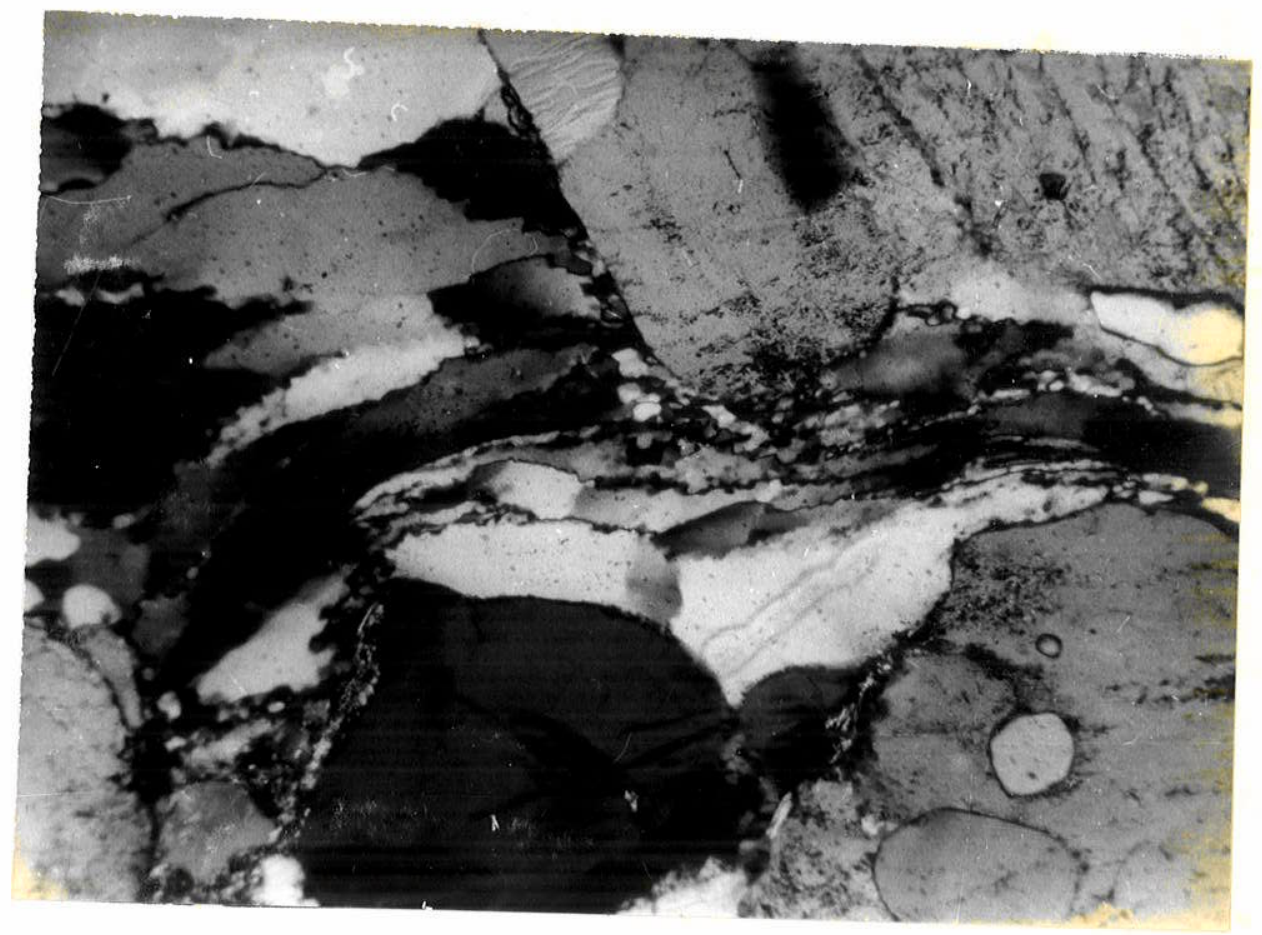

Microfoto 1 - Textura "fluidal" em leitos quartzo-feldspáticos de biotita hornblenda gnaisse. Nicois $x$, aumento $25 x$.

Tambēm chama a atenção, nesses gnaisses, a freqüente variação de orientação dos minerais biotita e hornblenda em relação à direção preferencial dos leitos, com a qual formam um ângulo aproximado de 300 . Essa orientação secundāria refere-se a uma discreta recristalização ao longo de micro-fraturas resultantes, provavelmente, dos esforços tectōnicos pōs-cristalinos ocorridos na fase final do Ciclo Brasiliano.

Mineralogia

Como jā ficou exposto, o biotita e o hornblenda gnaisses apresentam composição bastante variāvel. Os leitos claros são constituĩdos essencialmente por quartzo e plagioclāsio e subordinadamente por microclīnio. Ocorrem todas as proporções entre quartzo e plagiociāsio, predominando ora este, caso mais frequente, ora aquele mineral. o microclīnio, nem sempre presente, ra ramente predomina sobre o plagioclásio. Entre os máficos a biotita $\bar{e}$ o mais comum, seguida pela hornblenda, ocorrendo ainda epido to, clinozoisita, granada, clorita, muscovita, diopsídio, etc.,em 
proporções variadas.

0 quartzo ocorre quase sempre recristalizado, constituindo cristais irregulares a ovalados, sendo comuns as formas estiradas ou laminadas, com bordas microgranulados atingindo atē dimensões centimētricas. o contato entre grãos vizinhos ē predomi nantemente do tipo suturado. A extinção ondulante estā quase sempre presente, ao lado de fraturas e cordões de inclusão aproximadamente perpendiculares à maior dimensão. 0s cordões de inclusão tem sido interpretados como fraturas cicatrizadas (Tuttle, 1949) correspondendo à fase de deformação para-cristalina. Por outro la do, a constante presença de extinção ondulante e de fraturas ind cam que praticamente todo o gnaisse sofreu deformações pōs-cristá linas. 0 quartzo é pobre em inclusões, porēm, não é rara a sua ocorrēncia, sob esta forma, em outros minerais.

0 plagioclásio é do tipo sōdico, representado essen cialmente pelo oligoclásio chegando às vezes à andesina sōdica. Em bora possa ocorrer geminação polissintētica cerrada segundo a 1e Albita, apresenta-se comumente sem geminação, em grãos tanto sube drais quanto ovóides e arredondados. Pode aparecer na forma de ān tipertita, com quantidades de feldspato potāssico incluso perfä zendo no mäximo $5 \%$ do hospedeiro. São comuns inclusões de quartzo arredondado e mais raramente de biotita, hornblenda e apatita, principalmente na sua zona externa, denotando crescimento metamör fico. Não rara é a transformação do plagioclāsio em epĩdoto, bem como um grau variāvel de sericitização.

0s cristais apresentam, frequentemente, planos de geminação deformados, bordas microgranuladas e fraturas, estando estas preenchidas ou não por epỉdoto ou clorita. As vezes mostram extinção ondulante.

0 microclinio è predominantemente anēdrico, em vārios casos arredondado, sendo raras as formas subēdricas. Assume dimensões muito variāveis, podendo atingir $3,5 \mathrm{~mm}$ ao 1 ongo de sua extensão māxima. Os cristais são quase sempre pertīticos, com pertitas em filme, veios e manchas, indicando, as primeiras, tempera tura de gênese relativamente alta. Há casos em que a quantidade de albita presente na estrutura chega perfazer quase a metade do indivĩduo hospedeiro. Quanto à geminação, ocorrem as seguintes combinações: microclīnio desprovido de gemináção; microclīnio com ge 
minação em grade por todo o cristal; e microclīnio com geminação em grade em parte do cristal. Neste último caso, a parte gemina da forma quase sempre um anel externo de espessura variāvel, envolvendo um nūcleo desprovido de geminação. No contato entre microclinio e oligoclásio pode ocorrer mirmequita, quase sempre em forma de leque, com a convexidade voltada para o microclinio.

Inclusões são raras, ocorrendo grãos arredondados de quartzo e de plagioclásio, na maioria das vezes sericitizados. Tambēm hä evidências de deformações com recristalização,bem como deformações pōs-cristalinas.

A biotita é o mäfico mais frequente nestas rochas, ocorrendo tanto sob a forma de cristais tabulares, quanto consti tuindo fiapos irregulares nas rochas mais afetadas tectonicamente. Aparece como cristais isolados ou agregados orientados subpa ralelamente em linhas continnuas ou descontinuas, podendo esta intimamente associada à hornblenda, ocorrendo lado a lado ou in. tercrescidas, com contatos tanto nitidos quanto difusos.

Ao lado da förmula pleocrōica dominante, X-amare10 pälido, Z-castanho escuro, ocorre tambëm a variedade marrom avermelhada e vermelha acastanhada.

E relativamente frequente a cloritização da biotita, que pode iniciar nas bordas ou ao longo dos planos de clivagem desenvolvendo-se progressivamente por meio de ramificaçóes, chegando a transformar totalmente o filossilicato. Em muitas amostras essa transformação $\bar{e}$ total, resultando apenas a clorita.

A hornblenda è o segundo mineral mäfico em importância, representado principalmente pela variedade verde, fortemente pleocröica, com X-verde amarelado, Y-verde azulado e Z-ver de escuro, e pela castanha, mais rara. Prodominam as formas subedrajs, que podem atingir atē $4 \mathrm{~mm}$ ao longo de $c$, se bem que, de modo geral, se situem entre 0,5 e $0,7 \mathrm{~mm}$, podendo entretanto ocorrer hornblenda lamelar.

Constataram-se as seguintes particularidades com relação à hornblenda:

- Localmente forma-se às custas do diopsidio, observando-se todas as passagens entre a reação inicial e a transformação quase total de diopsîdio em hormblenda, (Microfoto 2). A 
reação pode iniciar tanto no interior do piroxênio quanto nas bordas. No primeiro caso, o inīcio da transformação pode dar-se num só ponto com o subsequente crescimento da hornblenda, ou en
tão, em vārios pontos concomitantes ocorrendo posteriormente a sua aglutinação. A hornblenda neo-formada é mais cinzenta que as demais, a clivagem menos desenvolvida e os contatos mais irregu1 ares.



Microfoto 2 - Hornblenda diopsīdio gnaisse. Reação diopsîdio-horn blenda. Nicois//, aumento $32 x$.

- E comum a transformação parcial da hornblenda em biotita e desta para clorita, ou diretamente tanto para clorita como para epĩdoto. Localmente, da reação hornblenda-biotita resul ta uma concentração de minerais de titanita, indicando hornblenda com alto teor em titanio.

- Em algumas amostras ocorre a presença de hornblen da castanha envolvida por hornblenda verde. volvendo a hornblenda:

Portanto, foram encontradas as seguintes reações en

Diopsĩdio $\rightarrow$ hornblenda

Hornblenda castanha $\rightarrow$ hornblenda verde $\rightarrow$ clorita

Hornblenda $\rightarrow$ biotita $\rightarrow$ clorita

Hornblenda $\rightarrow$ epĩdoto

Hornblenda $\rightarrow$ biotita $\rightarrow$ titanita 
Todas essas sēries de reações indicam, de

a lguma forma, uma diminuição de temperatura uma vez atingido o climax metamōrfico.

A hornblenda ē rica em inclusões de quartzo e de plagiocläsio arredondados, de titanita euedral e, menos frequen te, de apatita, opacos e biotita.

Epidoto e clinozoisita, são predominantemente anedrais a subedrais, equidimensionais, com tamanho mëdio de 0,2 a $0,3 \mathrm{~mm}$, apresentando cores verde-cinzentas a verde-amareladas. A separação entre os dois baseou-se na coloração mais intensa, sinal öptico negativo e cores de birrefringëncia vivas, para o epĩ doto, enquanto a clinozoisita $\bar{e}$ opticamente positiva e mostra co res de birrefringēncia anōmalas.

A presença do epidoto e da clinozoisita com teores variāveis, ē generalizada nesses gnaisses, contudo, muito rara mente ultrapassa a $5 \%$ da rocha. Entre ambos observam-se as seguintes relações, em ordem crescente: de frequēncia:

- Os cristais são constituĩdos por um nücleo de clinozoisita envolvido por uma capa de epĩdoto, (Microfoto 3); tercrescidos;

- Epidoto e clinozoisita ocorrem irregularmente in

- As duas variedades não ocorrem intercrescidas.

Em relação aos outros minerais, epidoto e clinozoi sita ocorrem sob três formas distintas:

nitidas;

- Como cristais isolados, não evidenciando reações

- Intimamente associados à biotita e à hornblenda. Neste caso, quanto maior a transformação da biotita em clorita,e da hornblenda em biotita, tambēm major serā o teor de epidoto e clinozoisita associado a esses minerais.

- Formando-se às custas do plagiocläsio. o epídoto desenvolve-se tanto nas bordas quanto no nücleo do plagioclāsio constituindo cristais irreguiares, amebóides, que se desenvolvem progressivamente por meio de ramificações irregulares em värios sentidos, mas preferencialmente ao longo dos planos da ge minação do plagioclāsio. 




Microfoto 3 - Epídoto zonado. Nicois X, aumento 100x.

0 diopsidio pode estar localmente presente nestes gnaisses. Foi registrada sua presença em alguns leitos na parte norte da área, pouco acima do vilarejo de Barão de Ataliba Nogueira e nas proximidades do vilarejo de Eleutērio, bem como a leste da ārea entre a Fazenda da Fortaleza e a divisa de estado. Nestes casos, o clinopiroxēnio ocupa leitos centimétricos, que se alternam com leitos ricos principalmente em hornblenda e algumas vezes com biotita, dos quais são normalmente separados por leitos predominantementé siālicos (Microfoto 4). Esta alternān cia entre leitos ricos em diopsídio e hornblenda ou biotita pode ser interpretada como um relicto da estrutura sedimentar pré- me tamörfica, com os diferentes horizontes representando fases de variação quĩmica durante a deposição de sedimentos.

o diopsîdio é neutro ou levemente esverdeado, neste caso desprovido de pleocroísmo. Ocorre sob a forma de cristais subedrais a anedrais, equlidimensionais, às vezes exibindo cliva gem segundo (100). O tamanho dos cristais, ao longo de $c$, situase quase sempre entre 0,5 e $0,7 \mathrm{~mm}$. 0 piroxēnio caracteriza- se por sua maior ou menor transformação em hornblenda, parecendo o- 


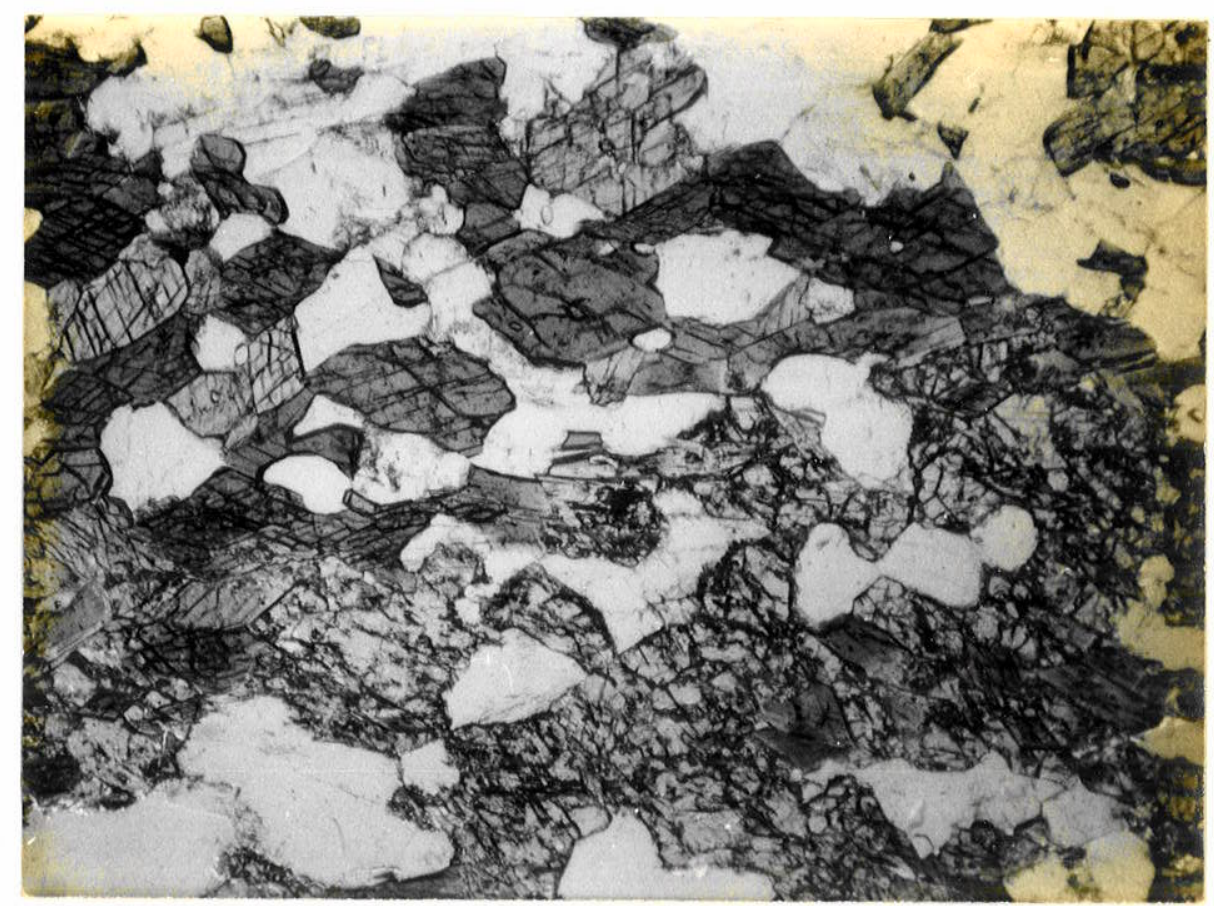

Microfoto 4 - Hornblenda diopsídio gnaisse. Contato entre leito rico em diopsídio (claro,parte inferior) e leito rico em hornblenda (escuro). Nicois//, aumento 10x.

correr, em alguns casos, uma passagem direta para epjidoto.

A granada é incolor a rosada em secções delgadas, onde constitui pequenos e raros cristais de forma subēdrica, qua se sempre deformados e fraturados, estando as fraturas abertas ou preenchidas por quartzo e biotita. Pode ocorrer associada à biotita, mas normalmenté não mostra relações com outros minerais, e geralmente estā isenta de inclusões. A magnetita, presente em pequena quantidade, com formas normalmente irregulares, esqueléticas e mesmo disseminadas, estā quase sempre associada à bioti ta. A muscovita é muito rara, ocorrendo sob a forma de pequenos cristais tabulares em rochas ricas em quartzo. Como acessōrios o correm: titanita, que chega constituir cristais de vārios milīme tros, cristais arredondados e subedrais de apatita, alēm de zircão, turmalina e alguma allanita. 
Os contatos entre o biotita e o hornblenda gnaisses, acima descritos, são predominantemente gradacionais. Em re lação às outras rochas metamōrficas neles presentes sob a for. ma de intercalações, ou lentes e camadas menores, os contatos são tanto transicionais, pelo incremento ou diminuição de um determinado mineral ou associação mineralögica, quanto abruptos.

Natureza prē-metamōrfica

Entre os vārios indícios, a nítida alternāncia en tre leitos claros e escuros,a variação observada na granulação e composição dos leitos no que tange à relação hornblenda/bioti. ta e quartzo/feldspato, e a presença de contatos gradacionais com rochas indubitavelmente para-metamörficas, sugerem que estes gnaisses resultem do metamorfismo de uma sequência sedimen tar arenosa-pelitica impura, possivelmente incluindo leitos tufosos.

2. Biotita e hornblenda gnaisses porfiroblästicos

São muito semelhantes aos gnaisses supradescritos no que tange a sua estrutura e composiçäo, diferindo dos mesmos pela presença de megacristais de feldspato potässico.

ocorrēncia

Estão presentes na forma de camadas, bandas ou lentes concordantes em relação aos gnaisses do arcabouço, com espessuras geralmente submëtricas, podendo, entretanto, atingir ate algumas dezenas de metros. Apresentam-se constituindo tanto concentrações particularmente grandes quanto ocorrēncias isoladas. No primeiro caso estão as situadas a SW da ārea : mapeada, a E de Barão Ataliba Nogueira e a SW de Eleutērio, que se encontram demarcadas no mapa litológico-estrutural anexo.No segundo caso constituindo pequenos corpos encaixados mais frequlentemente na associação litolögica (B), descrita no capitu10 anterior. As melhores exposições situam-se no äpice do corpo dobrado, a leste da ārea, localizado a NW da Fazenda dos Coutos, bem como no $\mathrm{Km} 35,3$ da rodovia Itapira-Lindōia e na 
rodovia Itapira-Jacutinga prōximo a entrada para Barão de Ataliba Nogueira, apresentando os dois primeiros matriz de biotita hornblenda gnaisses, e o último matriz de biotita ou hornblenda gnaisses.

\section{Descrição macroscópica}

As rochas que representam a matriz, exibem estrutu ra gnāissica, representada pela alternäncia de leitos escuros de granulação fina e leitos claros de granulação mëdia, ostentando as mesmas caracteristicas dos biotita e hornblenda gnaisses ante riormente descritos. Os porfiroblastos de microclïnio são rosa dos e estão concentrados nos leitos claros dos gnaisses. Estes im primem aos leitos claros uma cor rosada e, por intemperismo, pro duzem um material caolinitico esbranquiçado, diverso da rocha matriz.

Os megacristais são de dimensões variāveis, de 1 a $5 \mathrm{~cm}$, ao longo do seu eixo maior, e tamanho mëdio entre 2 e 3 $\mathrm{cm}$. Suas formas são predominantemente alongadas, ovaladas, poden do localmente ser prismäticas e, com menor freqüência, exibir formas irregulares, discóides ou arredondadas. Quase sempre mostram nittida geminação segundo a lei Carlsbard. E freqüente ocor rer concentrações de mäficos, principalmente de biotita, constituindo uma cinta que circunda parcialmente os megablastos. Estas concentrações foram interpretadas como resultante de segregação metamōrfica.

No que diz respeito à distribuiçăo dos megacris tais, podem ocorrer as seguintes relações:

- Variação dentro do mesmo lejto, tanto na lateral quanto ao longo do leito, ora exibindo baixa densidade, com os megacristais bem individualizados, ora alta densidade, estando mesmo soldados, constituindo linhas continuas ou estranguladas lembrando um rosärio, perdendo, com isso, sua individualidade.

- Densidade muito variāvel de fenoblastos de uma banda para outra, apresentando leitos de reduzidas. espessuras com elevada densidade, intercaladas com faixas de vārios decïmetros fracamente porfiroblāsticas, podendo estar separadas por leitos escuros. 
- Em dobras de pequena amplitude,principalmente do tipo isoclinal, a densidade dos porfiroblastos $\overline{\mathrm{e}}$. nitidamente maior nas partes convexas do que nos seus flancos.

- Os leitos representados pelos mäficos, normalmen te estão desprovidos de porfiroblastos.

os porfiroblastos de microciinio estão com maior dimensão orientadas paralelamente à gnaissificação. Localmente acham-se orientados segundo duas ou mesmo trēs direções. Neste caso a direção paralela à gnaissificação $\bar{e}$ inteiramente predominante, formando, com as direções secundārias,ângulos freqüentemente em torno de 300 . As direçōes secundārias não são per sistentes, adaptando-se posteriormente à direção principal pelo curvamento do plano de orientação secundāria. De modo geral, a foliação tende a moldar-se de forma a contornar os megablastos.

Nas zonas de intensa deformação pōs-cristalina, os porfiroblastos exibem orientação segundo os plianos de cisalhamen to e mostram-se fragmentados ou fusiformes, por fricção tectôni$\mathrm{ca}$.

\section{Descrição microscōpica}

Estas rochas apresentam texturas porfiroblästicas, com megacristais de microcīinio numa matriz de granulação mëdia a fina, granoblästico-cataclästica parcialmente recristalizada. As evidências dos efeitos cataclästicos de grau variāvel, com recristalização apresentada pelos gnaisses da matriz, estão menos pronunciadas nos megacristais de microclinio: Contudo, os efeitos cataclāsticos pös-cristalino afetaram tanto a matriz quanto os megacristais que se encontram fragmentados, estrangulados ou estirados.

Como jă dissemos, a mineralogia $\bar{e}$ semelhante aos biotita e hornblenda gnaisses anteriormente descritos, com a diferença destes apresentarem fenoblastos de microclinio. 0 microclinio ocorre tanto constituindo os porfiroblastos como fazendo parte da matriz, neste caso é sempre xenomōrfico. Microscopicamente os porfiroblastos apresentam bordas irregulares, e normalmente se encontram microgranulados com as fraturas geralmente abertas e preenchidas por quartzo e biotita cloritizada. A micro 
granulação e mais intensa nas suas bordas. São quase sempre pertiticos, com pertitas em filme, veios e manchas, chegando,em alguns casos, a perfazer mais da metade do hospedeiro (meso-pertita). A geminação em grade estā presente em quase todos os porfiroblastos, podendo ocorrer por todo o cristal, ou em parte deles. Neste $\bar{u}$ ltimo caso, a parte geminada pode ocorrer tanto nas bordas, constituĩndo um semi anel externo, como em manchas dispersas pelo interior do cristal. E comum a ocorréncia de mirmequita nos contatos entre o oligocläsio e os porfiroblastos de mi croclinio, normalmente em forma de leque, com a convexidade voltada para o microciinio.

Inclusões nos porfiroblastos são abundantes,princi palmente de quartzo, plagioclāsio e biotita. Os grãos de quartzo são geralmente arredondados de tamanhos mais ou menos uniformes. A biotita, na forma de pequenas lamelas, concentra-se principalmente nas bordas dos megablastos. Os plagiocläsios, quase sempre sericitizados, são xenomōrficos, de dimensōes variāveis e encontram-se distribujdos regularmente pelo cristal.

Relação de contato

os contatos entre as faixas ou bandas constituidas pelos gnaisses porfiroblästicos, intercalados com os não porfiro blästicos, são predominantemente bruscos, e sō excepcionalmente processam-se por uma redução na intensidade dos fenoblastos atē - seu desaparecimento total. Contatos abruptos entre estes gnais ses podem ser observados no $\mathrm{km} 35,3 \mathrm{da}$ rodovia Itapira-Lindöia e na rodovia Itapira-jacutinga próximo à entrada para o vilarejo Barão Ataliba Nogueira. O segundo caso pode ser notado numa estrada de terra que corta o äpice da ocorrência dobrada a $S W$ da ārea, onde o biotita gnaisse apresenta uma faixa porfiroblästica que a partir de um plano começa a sofrer visĩvel redução no teor dos porfiroblastos, podendo ser encontrado's alguns deles disper sos atē quase 10 metros distante da ärea de maior concentração.

Origem

Levando-se em consideração que:

- os gnaisses porfiroblästicos ocorrem intercala- 
dos, constituindo camadas, leitos e lentes, com gnaisses desprovi dos de porfiroblastos, com os quais exibem contatos abruptos, não
tectónicos;

- os gnaisses porfiroblästicos estão afastados das āreas de influência dos granitos brasilianos;

- a matriz dos gnaisses porfiroblästicos è similar estrutural e mineralogicamente aos biotita e hornblenda gnaisses descritos no item anterior, e interpretados como sendo de origem sedimentar;

- os fenoblastos de microclinio apresentam a mesma idade dos gnaisses que compõem sua matriz, como serä demonstrado no capĩtulo VII referente ã geocronologia;

as seguintes conclusões:

essas evidēncias permitem, em linhas gerais, tecer

A - Descartar uma origem a partir de processos metassomäticos para estes gnaisses porfiroblästicos.

B - Que os porfiroblastos de microclinio tenham se originado por crescimento metamōrfico diferencial a partir de uma variação faciolögica, rica em potässio, do sedimento original.

3. Biotita e hornblenda gnaisses anatexiticos e migmatiti $\cos$

A utilização dos termos migmatîticos e anatexīticos, teve por base a definição clássica de Sederholm (1907), ou seja, os migmatitos são rochas hỉbridas resultantes da infiltração de material granitico mais novo (neossoma) numa rocha metamörfica prë-existente (paleossoma). Na Finländia, onde Sederholm criou o termo, o paleossoma ē representado por gnaisses de idade prē- cam briana mëdia e o neossoma por material granitico de intrusōes tar di-tectōnicas. Desta maneira, os migmatitos representam um sistema aberto no qual o material introduzido e sensivelmente mais jovem que a rocha invadida. Sob este aspecto, os migmatitos distin guem-se nitidamente dos anatexitos que resultam de uma mobilização "in situ" de material leucocrätico (leucossoma) acompanhado de consequlente concentração local de material mäfico (melanossoma). Anatexitos são, portanto, sistemas fechados nos quais o leu- 
co- e o paleossoma são de mesma idade. Quando o material remobilizado nos anatexitos è substancial, permitindo a concentração de grandes massas granīticas (palingênese) que são introduzidas ou injetadas em rochas metamörficas situadas a um nivel superior ao da palingēnese, tambēm ocorre a formação de migmatitos.

A SW da ārea mapeada, com base em observações de campo e nos dados geocronolögicos por nōs obtidos (ver capitulo referente a geocronologia), foi possivel caracterizar gnaisses que sofreram efeitos de anatexia parcial, com posterior infiltra ção de material granitico mais jovem.

Biotita e hornblenda gnaisses anatexiticos

ocorrēncia

A maior ocorrēncia encontra-se a $S W$ da ārea mapeada, constituindo um corpo de forma ligeiramente ovalado que se estende ao longo da rodovia Itapira-Lindōia, desde as proximida des da Fazenda Cristālia atē ao sul, onde deixa a ārea. Uma ocor rência incipientemente anatexitica, de carāter local e não repre sentada na carta geolögica, situa-se na rodovia Itapira-Jacutinga, a NE de Sapucai, jā no Estado de Minas Gerais. As meThores exposições situam-se nos cortes da rodovia Itapira-Lindöia, na entrada da Fazenda Cristália e na entrada para o Bairro da Ponte Nova.

\section{Estruturas}

As rochas afetadas pela anatexia parcial são bioti ta e hornblenda gnaisses fitados e bandeados semelhantes aos do arcabouço rochoso da região mapeada. Estão presentes tambēm,prōximo a Fazenda Cristälia, lentes de espessuras decimētricas de anfibolitos concordantes ou ligeiramente discordantes com a gnaissificação, e que não estão afetados pela anatexia.

o processo è iniciado pela segregação das rochas "in situ", passando por estägios de anatexia incipiente atē chegar a um estägio mais avançado. Pelo início e aumento de mobilização dos leitos claros, os gnaisses fitados e bandeados passam 
progressivamente a gnaisses anatexiticos, desenvolvendo leucosso ma quartzo-feldspätico e melanossoma rico em biotita e hornblenda. Num estāgio inicial, como pode ser observado em corte da rodovia na entrada para o Bairro da Ponte Nova, o leucossoma mantēm-se paralelo com as estruturas acamadas e às vezes exibe boudinagem. Neste estāgio, o material nitidamente mobilizado corres ponde a menos de $10 \%$ da rocha, sendo os contatos leucossoma-mela nossoma predominantemente nitidos. Por outro lado, no caso de maior intensidade de anatexia, os gnaisses são acompanhados de estruturas migmatiticas do tipo dobradas, ptigmaticas e fleb $\overrightarrow{j-}$ ticas (Mehnert, 1968), com contatos leuco-melanossoma às vezes difusos. Este ūitimo caso pode ser observado na entrada para a Fazenda Cristälia.

Os leitos de leucossoma são brancos a esbranquiçados, aferindo às rochas cores cinzentas que, pelo intemperismo, riginam um material argilo-arenoso, de cor branca.

\section{Textura}

As bandas leucocrāticas resultantes do efeito da anatexia parcial sobre os gnaisses do arcabouço, mostram uma ten dência no sentido da transformação das texturas granoblästica e blastomilonitica, características dos gnaisses, em textura grani tica. Assim, as bandas leucossomāticas são rochas predominante mente equligranulares, exibindo texturas xenoblästicas, de granulação mëdia a fina. E comum, em secções delgadas, incipiente foliação ressaltada por raros cristais de biotita e muscovita isoorientados paralelamente entre si. Localmente apresentam textura milonitica com grãos minerais deformados, fraturados e rodeados por material de granulação mais fina (textura em moldura). A textura lepidoblāstica e nematoblästica nos leitos escuros são mais evidentes do que nos gnaisses regionais, devido à concentra ção principalmente da biotita, seguida pela hornblenda.

\section{Mineralogia}

A mineralogia desses gnaisses è relativamente simples, sendo o melanossoma constituido pelos mesmos minerais dos biotita e hornblenda gnaisses do arcabouço rochoso, enriquecidos 
em biotita e hornblenda pela maior ou menor mobilização dos leitos claros. 0 leucossoma é representado basicamente por plagioclä sio e quartzo em proporções semelhantes, podendo predominar um ou outro. 0 microclinio pode ou não estar presente, representando no mäximo cerca de $5 \%$ destes leitos. Ocorrem, tambëm, quantidades me nores de biotita, muscovita e raras hornblendas.

0 quartzo aparece na forma de grãos irregulares a lobulados, com dimensões de 0,7-0,3 mm e se caracteriza por sua extinção ondulante. Os contatos entre os grãos são predominante mente do tipo suturado.

Os plagioclásios do tipo oligoclāsio bāsico a andesina äcida, são eqlidimensionais, xenomörficos e mais raramente hipidiomörficos, com dimensão mēdia de $0,8 \mathrm{~mm}$. Apresentam-se comu mente desprovidos de geminação, e praticamente sem inclusões. Podem estar parcialmente sericitizados.

0 microclinio, de ocorrência reduzida, constitui cristais xenomōrficos de pequenas dimensões. Geminação em grade quase sempre presente, assim como pertita em filmes e veios. Podem ocorrer algumas inclusões de plagioclāsio e quartzo arredonda dos.

A biotita, contendo raros opacos disseminados, $\bar{e}$ lamelar e fracamente cloritizada. A muscovita, tambëm lamelar, po de ocorrer concentrada localmente, estando frequentemente associa da à biotita, com a qual pode estar intercrescida, exibindo conta tos normalmente nïtidos. A hornbienda, representada pela varieda de verde, ē bastante rara. Podem ocorrér ainda minūsculos cristais de epĩdoto associados à biotita. Esses minerais estão distri buifos heterogeneamente no leucossoma, estando predominantemente iso-orientados.

Migmatitos

Ocorrência

Os biotita e hornblenda gnaisses anatexiticos, ante riormente descritos, podem estar localmente afetados por fenōme nos de migmatização. Estes locais correspondem a alguns nücleos pröximos à Fazenda Santo Antonio e ao longo da rodovia Itapira - 
Lindōia, ao sul do referido corpo, representando, estes ūitimos:, as melhores exposições. Os afloramentos frescos são de pequeno porte, estando a maior parte deles totalmente alterados e cober tos pela vegetação, impossibilitando maiores observações.

\section{Descrição Macroscōpica}

São rochas macroscopicamente compostas, constituin do duas partes petrograficamente diferentes: o paleossoma, repre sentado pelos gnaisses anatexiticos supra descritos, e o neosso ma, por material granitōide.

0 aspecto marcante destes migmatitos è sua genēri ca cor rosada, que é a cor do neossoma granitico injetado profusamente nos gnaisses anatexiticos de cores cinzento-esbranquiçados, provocando a sua migmatização (Foto 4). Estruturalmente, ocorrem, nos raros afloramentos os tipos acamados, flebiticos e dobrados, observando-se apenas localmente a predomināncia do ne ossoma sobre o paleossoma (Foto 5). Os limites entre o neo- e pa leossoma são normalmente nitidos, e às vezes um pouco difusos. No ültimo caso parece ocorrer a recristalização de uma fina faixa do paleossoma diretamente em contato com o neossoma, a qual se mostra enriquecida em māficos, denotando provāvel segregação de certa taxa de quartzo e feldspato do paleossoma para o interior do neossoma.

Textura e Composição

Ainda que a maioria das amostras examinadas exibam ao microscópio sinais de acentuada deformação pōs-cristalina, em certos casos as rochas do neossoma apresentam típica textura granular, xenomörfica, de granulação mēdia. Sua composição e- extremamente simples, sendo constituida essencialmente por microclínio, oligocläsio e biotita, faltando praticamente hornblenda. 0 microclinio predomina levemente sobre o oligocläsio, e o quart zo perfaz cerca de $20 \%$ destas rochas. 0 microclinnio apresenta-se normalmente com geminação em grade e ë pertítico. 0 oligocläsio e predominantemente xenomörfico, quase sempre desprovido de gemi nação e pouco sericitizado. Tanto o microclínio como o oligocla sio estão praticamente isentos de inclusões. A biotita, pouco 


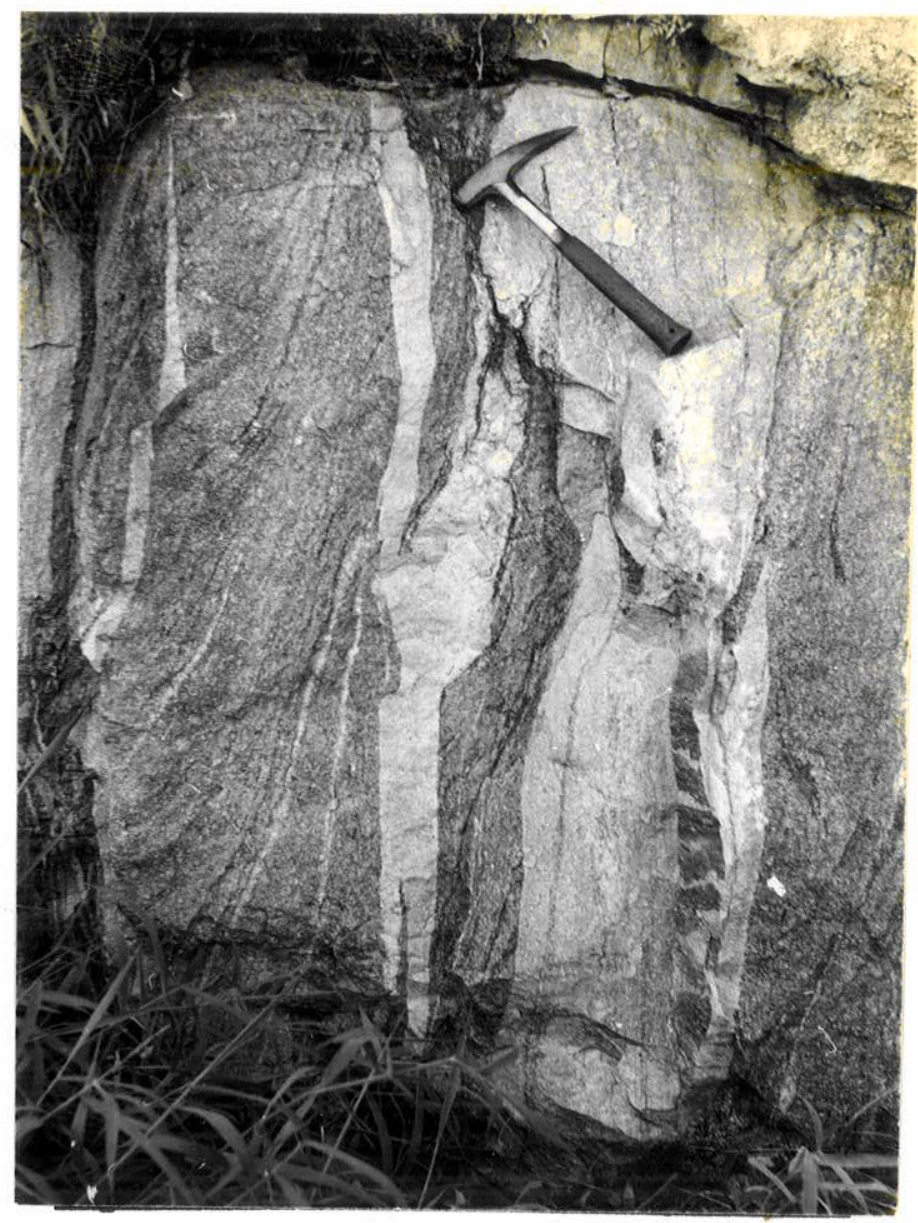

Foto 4 - Migmatito. Neossoma discordando levemente da foliação do paleossoma, com contatos nîtidos. Rodovia Itapira Lindōia, Km 26.

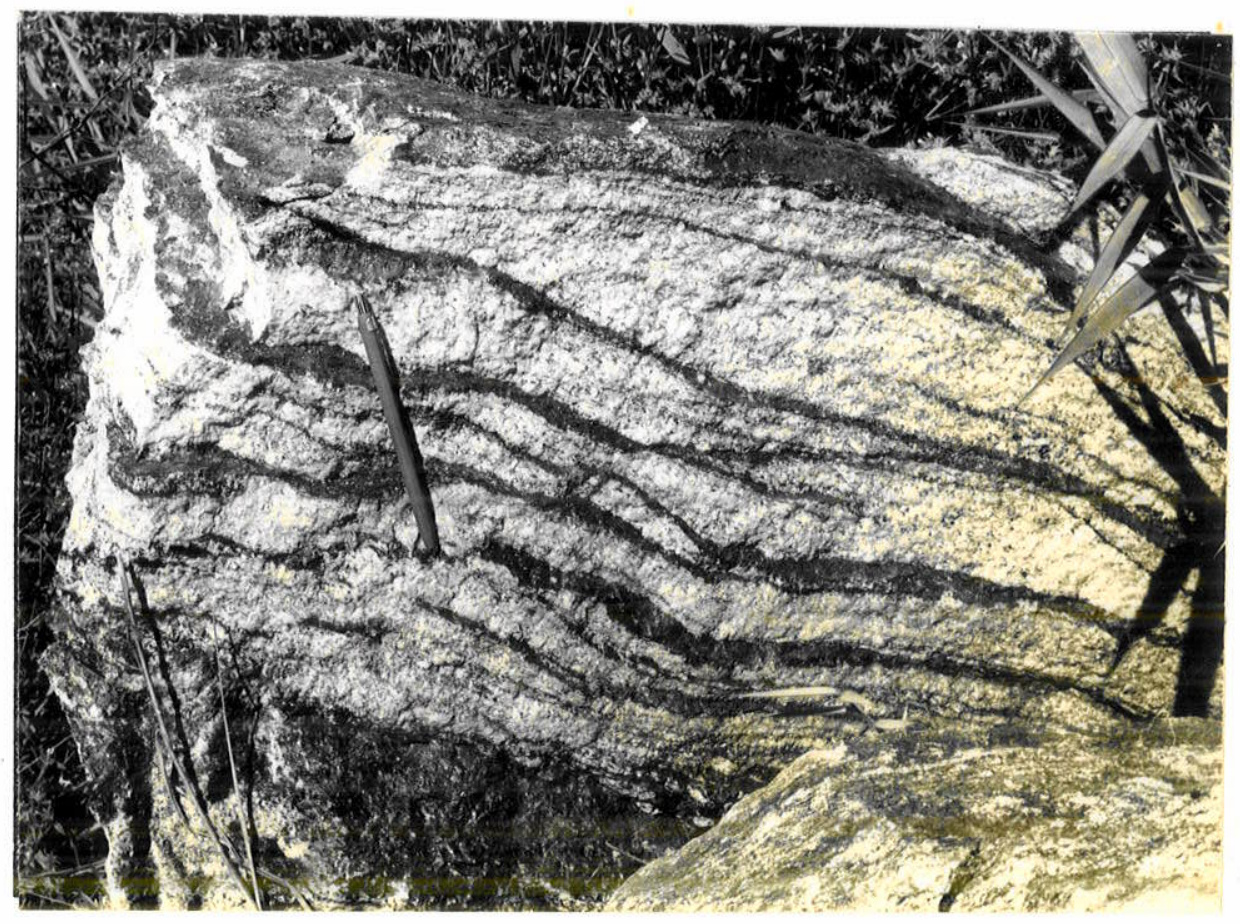

Foto 5 - Migmatito. Predominância do neossoma sobre o paleossoma. Rodovia Itapira-Lindóia, Km 26. 
freqüente, mostra orientação irregular, geralmente alterada para clorita, ocorrendo este mineral tanto em intercrescimento paralelo com a biotita quanto substituindo-a completamente. Os acessörios estão representados por minerais opacos. Apatita e zircão são raros.

0 paleossoma, como jā citado, ē representado pelo biotita e hornblenda gnaisses anatexiticos, pouco modificados de acordo com o tipo estrutural do migmatito.

\section{Considerações Finais}

As observações acima expostas para estas rochas, bem como os dados geocronolögicos apresentados no capitulo VII, revelaram que:

- a passagem progressiva dos gnaisses fitados e ban deados para os gnaisses anatexiticos se dä pelo inĩcio:e aumento de mobilização dos leitos claros;

- os leitos e veios do leucossoma dos gnaisses anatexiticos, apresentam baixo teor de microclinio, normalmente infe riores a $5 \%$;

- o biotita gnaisse anatexitico situado a NE do vilarejo de Sapucai e similar aos gnaisses anatexiticos que sofreram migmatização a SW da ārea mapeada, apresentou isōcrona verdadeira com $2.230 \pm 39 \mathrm{~m} . \mathrm{a}$. (Figura 22);

- o plagioclásio e o microclīnio praticamente se equivalem em volume no neossoma dos migmatitos;

- os migmatitos apresentaram isōcrona de referēncia com $600 \pm 30 \mathrm{~m} . \mathrm{a}$. (Figura 24);

Estas consideraçōes levam-nos a sugerir que os referidos biotita e hornblenda gnaisses são o produto de metamorfis mo crescente que atingiu, em condições favoräveis, o desenvolvimento de uma anatexia parcial "in situ". Esta fase estaria rela cionada ao Ciclo Transamazōnico, ou, mais provavelmente, a ciclos mais antigos, conforme descrito por Fiori (1979), para a, região Pouso Alegre-Machado (MG). Posteriormente, durante a fase tardi-o rogênica do Ciclo Brasiliano, estas litologias sofreram localmente penetração de material grañ̈tico. 
4. Gnaisses Graniticos

Constituem litologias relativamente frequente ārea abordada, encontrando-se distribuídos da seguinte forma:

- Constituindo lentes ou camadas com espessuras que podem atingir at $\vec{e}$ algumas dezenas de metros, embutidos concordantemente nos biotita e hornblenda gnaisses da associação litolögica (B), com os quais exibem contatos tanto transicionais quanto abruptos. Embora de distribuição relativamente homogênea em toda a unidade, estes gnaisses graniticos são subordinados e pouco expressivos. Boas exposições podem ser vistas no $\mathrm{km} 35,3$ da rodovia Itapira-Lindōia e no leito do Cōrrego do 0legārio, ao sul da Fazenda Santo Amaro.

- Constituindo, juntamente com os biotita gnaisses, a associação litolōgica (L) a SE da ärea. Nesta associação, os gnaisses graniticos se intercalam concordantemente com os biotita gnaisses, exibindo contatos predominantemente transicionais e, às vezes, abruptos. Os gnaisses granïticos são mais frequentes na porção $W$ da associação, principalmente na sua parte superior,ocor rendo a NW do Cörrego do Recreio, ao $S$ da rodovia Itapira-Lindöia, estendendo-se para $E$ atē a Serra das Aguas Claras. Na faixa $E$ da unidade, os gnaisses graniticos podem ser observados em värios trechos ao longo do Cörrego do Barrocão, na parte $S$ da ārea, e no limite dos Estados de São Paulo e Minas Gerais, a N da associação.

- Representando duas ocorrências onde se constitui nos tipos litolögicos amplamente dominantes, situados a NW e E da ärea. Nestas, os gnaisses granīticos apresentam intercalações menores e concordantes de biotita e hornblenda gnaisses,onde os con tatos são ora gradacionais, ora abruptos. Seus contatos com as un dades vizinhas são eminentemente tectōnicos.

\section{Estruturas}

Embora de relativa homogeneidade, os gnaisses grani ticos apresentam uma discreta estrutura foliada tendendo a gnaissica. Esta feição e determinada pela presença de leitos ora enriquecidos em quartzo, podendo ocorrer grandes cristais alongados, ora pela predomināncia de feldspatos de cores esbranquiçadas e rosa 
das, e pela presença de mäficos isomorientados. A granulação tambëm pode apresentar variações, exibindo delgados leitos paralelos entre si, de maior ou menor granulação.

As cores destas rochas estão na dependēncia do tipo e proporção dos feldspatos que apresentam, sendo na maioria das vezes róseos, devido à riqueza em feldspato potāssico rōseo. Contudo, na associação litológica (L), constituĩda pelos gnaisses graniticos e biotita gnaisses, a SE da ärea, ocorre uma grande va riação na proporção entre os feldspatos potässicos e plagiocläsios, manifestando-se numa variação das cores destas rochas. Neste caso, predomina a cor cinza-esbranquiçada pela riqueza em plagiocläsios. De modo geral, pelo intemperismo, estas rochas produzem um material areno-argiloso esbranquiçado.

Devido à sua maior homogeneidade, săo mais resisten tes à erosão e formam morros ovalados ou irregulares.

\section{Textura}

A textura destas rochas ē essencialmente granoblāstica, mais ou menos cataclästica. A granulação é mēdia, com varia ções locais tanto para fina quanto para grossa. Apresentam caracterīsticas de recristalização metamörfica, falta de idiomorfismo da maior parte dos minerais componentes e bom engrenamento dos cristais. Os grãos de quartzo nas concentrações monominerälicas são um tanto alongados e se dispõem paralelamente às camadas. Os leitos de quartzo exibem, de maneira mais comum, textura granoblästica pavimentosa com justaposição perfeita dos grãos. 0 alongamento nos demais minerais não ē pronunciado, com exceção das biotitas e raros anfibōlios que ressaltam a foliação das rochas. Algumas vezes as biotitas se mostram orientadas segundo duas $\therefore$ orientações, o que atesta superposição de pelo menos duas fases de eventos tecto-termais nas mesmas rochas.

Tambëm nos gnaisses graniticos, o aspecto geral sugere que houve milonitização antiga com posterior recristalização, ou que a recristalização foi acompanhada de fortes deformações tectónicas, tendo aquela superado esta. Tanto nos gnaisses graniticos como nos biotita gnaisses da unidade situada a SE da ārea,a textura reflete uma histōria geolögica um tanto diferente das demais rochas. E frequente, em secções delgadas, a presença 
grãos de quartzo microdobrados, associados à textura de f ] $u \times 0$ (Microfoto 1), evidenciando um meio de elevada plasticidade.

Evidēncias de cataclase pōs-cristalina são frequen tes e se manifestam principalmente pela microgranulação, extinção ondulante anormalmente forte, deformações de geminação,micro falhas, epidotização e cloritização.

\section{Mineralogia}

Estas rochas são diferenciadas mineralogicamente dos demais gnaisses, por apresentarem baixo teor em mäficos, nor malmente inferior a $5 \%$. São compostas essencialmente por quartzo, plagiocläsio e microclïnio, sendo característica a sua rique za em quartzo. A proporção entre plagiocläsio e microcĩnio ē va riāvel, ora havendo uma equivalēncia entre ambos, ou leve predomỉnio do microclínio, ora prevalecendo o plagiocläsio. Este ūltị mo caso pode ser observado principalmente nos gnaisses graniticos na unidade a SE da ärea. Os minerais mäficos comuns são a biotita cloritizada, a hornblenda e, subordinadamente, epidoto, clinozoisita, titanita, diopsidio, calcita, granada, opacos, tur malina, apatita e zircão.

o quartzo dos gnaisses graniticos apresenta-se de duas formas. Nas camadas monominerālicas mostra granulação mais grosseira, quase sempre recristalizado, constituindo cristais xe nomōrficos, alongados e de dimensões atē centimëtricas. A extin ção ondulante estā quase sempre presente, evoluindo localmente para bandas de deformação, ao lado de fraturas e cordões de inclusões aproximadamente perpendiculares à sua maior dimensão. Uma segunda forma de apresentação do quartzo è a de grãos minūsculos, quase sempre arredondados e espalhados em pequena quantidade pela matriz feldspätica. A extinção ondulante ë menos pronunciada para estes ūltimos grãos. 0 quartzo ē pobre em inclusões.

0 plagiociásio è do tipo sōdico e estä representado essencialmente pelo oligoclāsio. As vezes pode chegar à andesina södica. Seus grãos são predominantemente xenomörficos, mais ou menos equidimensionais e com bordas irregulares. Suas dimensões são um tanto variāveis, mas quase sempre inferiores a 1,0 mil. A geminação polissintētica cerrada, segundo a lei Albita, $\bar{e}$ 
menos freqüente que a dos biotita gnaisses anteriormente descr $\underline{j}$ tos, e, quando presente, exibe, muitas vezes, deformações no plano (010). O grau de sericitização ë bastante variävel, estando praticamente ausente em algumas amostras e sendo intensa em outras, principalmente nos cristais de dimensões maiores. In clusões são raras, estando presentes algumas de quartzo arredon dado.

0 microciinio constitui cristais xenomörficos, com dimensões variāveis, podendo atingir atē $3,0 \mathrm{~mm}$, mas em mēdia inferiores a $1,0 \mathrm{~mm}$. Äs vezes pode apresentar-se sob a forma de metablastos subedrais, raramente ultrapassando $1,0 \mathrm{~cm}$ na maior extensão. A geminação em grade estā quase sempre presente, prin cipalmente nos metablastos. De modo geral são pouco pertiticos, predominando os tipos filme e veio. Pode tambëm ocorrer inter crescimento mirmequītico nas interfācies com o oligoclásio, qua se sempre na forma de leque, com a convexidade dirigida para microcitinio.

As inclusões são raras, podendo ocorrer as de plagioclásios sericitizados e quartzo, ambos arredondados. Nos raros fenoblastos ocorrem, ainda, inclusões de biotita e opacos.

A biotita ocorre tanto sob a forma de cristais tabulares, quanto constituindo fiapos irregulares nos termos deformados. Praticamente todos os cristais de biotita encontram se totalmente transformados em clorita. Estas são de coloração verde escura, bastante homogênea, acompanhadas. frequlentemente por minüsculos agregados de epidoto e clinozoisita. A transformação pode iniciar nas bordas ou ao longo dos planos de clivagem desenvolvendo-se progressivamente por meio de ramificações, chegando a transformar totalmente os filossilicatos. A biotita e a clorita apresentam-se distribuidas heterogeneamente em pequenos agregados iso-orientados.

A hornblenda constitui cristais pequenos, irregu lares, de aspecto disseminado, em pequena quantidade, podendo mesmo estar ausente. Apresenta as mesmas caracteristicas observadas nos biotita e hornblenda gnaisses do arcabouço rochoso. E representada principalmente pela variedade verde, fortemente pleocröica. Localmente forma-se às custas do diopsidio, poden- 
do observar-se todas as passagens entre a reação inicial e a transformação quase total do diopsĩdio em honblenda. Esta hornblenda neo-formada è mais cinzenta que as demais. Tambēm è comum a transformação parcial da hornblenda em biotita, e desta para clorita, ou diretamente para clorita e epidoto. Todas estas transformações evidenciam uma vez mais o retrometamorfismo que afetou toda a ārea.

Epidoto e clinozoisita, ocorrem principalmente co mo produtos de transformação do plagioclāsio, e subordinadamente da hornblenda. Constituem cristais anedrais a suedrais, equj dimensionais, com tamanho mëdio de $0,2 \mathrm{~mm}$. As relações entre epidoto e a clinozoisita, e destes com os outros minerais, são as mesmas descritas anteriormente para os biotita e hornblenda gnaisses.

0 diopsidio, representado por raros cristais sub edrais e anedrais, foram verificados em algumas amostras oriundas das proximidades da Serra das Aguas Claras. 0 tamanho dos cristais, ao longo de $c$, situa-se ao redor de $0,3 \mathrm{~mm}$. 0 diopsidio e neutro ou levemente esverdeado, neste caso desprovido de pleocroismo, caracterizando-se pela maior ou menor transformação em hornblenda.

A calcita, tambēm presente em amostras provenien tes das proximidades da Serra das Aguas Claras, representa menos de $1 \%$ das amostras. Os cristais são anedrais, de atē $0,3 \mathrm{~mm}$, e ocorrem associados principalmente aos plagiocläsios, ou em forma de preenchimento ao longo dos planos de clivagem da hornblenda, ou dos planos de geminação dos plagioclāsios. A sua ocorrência limita-se a āreas de minerais alterados ou exibindo adiantada fase de transformação metamórfica. Neste caso sugere tratar-se de mineral liberado pelas reaçōes metamōrficas.

Titanita e opacos. São acessōrios comuns, predom nando quase sempre a titanita. Os opacos são representados pela magnetita sob a forma de pequenos cristais sub-e anedrais. Ja na titanita são comuns as formas euedrais e a geminação polissintētica. Ocorrem tanto sob a forma de cristais independentes quanto intimamente associados à horblenda e ao epídoto.

A granada $\overrightarrow{\mathrm{e}} \cdot \mathrm{do}$ tipo almandina, rosa em. secções delgadas, onde constitui pequenos e raros cristais, algumas ve- 
zes deformados, geralmente isentos de inclusões. Ocorre preferen cialmente associada ā biotita. A muscovita $\overrightarrow{\mathrm{e}}$ muito rara, aparecendo sob a forma de pequenos cristais tabulares.

ocorrem ainda cristais subedrais a anedrais de apa tita, alēm de zircão, turmalina e alguma allanita.

Origem

Os gnaisses graniticos, que se apresentam intercalados com as rochas tipicamente metassedimentares da associação litologica (B), devem ter-se originado a partir de material sedimentar. Esta conclusão encontra apoio no fato destes gnaisses graniticos se apresentarem sob a forma de lentes ou camadas dispostas concordantemente com as demais rochas metassedimentares, com as quais exibem, muitas vezes, contatos gradacionais. A alta percentagem de microclīnio para alguns destes corpos, o que näo ë normal para as litologias do Grupo Amparo, pode representar uma variação faciolögica da rocha sedimentar original. Poderia tambēm representar o efeito de uma feldspatização potássica, como no caso do gnaisse granitico do $\mathrm{km} 35,3$ da rodovia Itapira Lindöia, que encontra-se em contato com biotita gnaisse porfiroblästico aparentemente afetado por metassomatismo potässico. Este gnaisse granitico apresentou idade de $2.085 \pm 88 \mathrm{~m}$.a. (Figura 19).

No caso dos gnaisses graniticos integrantes das associações litolögicas (L) e (M), torna-se dificil tecer considerações a respeito de seu material original. Estas associações litolögicas caracterizam-se pela ausência de sequências nitidamente metassedimentares. A presença de corpos com equivalência, ou mesmo predominância do microclīnio em relação ao plagioclásio, deve refletir materiais originais diferentes. A falta de idiomor fismo dos minerais, principalmente do plagiocläsio, tambēm não deve servir como critērio para determinar sua origem, tendo- se em vista a complexa histōria metamörfica destas rochas. Portanto, atê o momento, não e possīvel dizer se os gnaisses graniti cos destas associações litolögicas, originaram-se a partir de rochas puramente sedimentares, ou em parte igneas. 


\section{Generalidades}

Recebem esta designação pelo fato de apreșentarem uma granulação mais grosseira que o gnaisse normal da ärea, conferindo um aspecto pegmatitico a estas rochas. Não : constituem massas maiores, estando as ocorrências limitadas, na maioria das vezes, a concentrações de pequenas manchas, associadas principal mente aos gnaisses graniticos. Excepcionalmente, constituem faixas continuas ou descontinuas, de forma mais ou menos irregular, com dimensões de uma a duas dezenas de metros de espessura e algumas centenas de metros de extensão, como no caso da ocorrência situada prōximo ä margem esquerda do Rio do Peixe, a NE da Fazen da São Jerōnimo. Assumem a configuração de pequenas lentes, nō los, concreções e bolsões ovalados a irreguitares, com algumas dé zenas de metros. Estas rochas foram observadas principalmente nos arredores da Fazenda da Fortaleza. Uma das ocorrēncias,situa da na encosta $E$ da Serra do Matão, encontra-se atualmente em fase de pesquisa para verificar sua viabilidade econōmica.

\section{Descrição}

Estas rochas são esbranquiçadas e, às vezes, com tonalidades rosadas. A nivel de afloramento é bem visivel uma es trutura gnaĩsica. São compostas essencialmente por quartzo e feldspatos. Os mäficos acham-se concentrados sob a forma de delgados leitos descontīnuos ou agregados nodulares achatados, cons tituidos pela hornblenda e alguma biotita. Resultam provavelmente da segregação metamōrfica dos minerais siālicos. Estes lejtos encontram-se mais ou menos paralelos entre si, ressaltando a gnaissificação da rocha.

A textura $\vec{e}$ do tipo granoblästica, com granulação variando entre 0,5 e $1,0 \mathrm{~cm}$ para o quartzo e os feldspatos, sendo menor para os mäficos. Näo ocorre uma individualização de le tos ricos em quartzo e ricos em feldspatos, mas uma distribuição heterogênea entre estes minerais. Macroscopicamente, os feldspatos constituem, na maioria das vezes, äreas continuas e muito ho mogēneas onde os cristais perdem a sua individualidade. Tambēm a textura cataciästica è frequente nestas rochas.

A passagem dos termos grosseiros para os de granula 
ção normal $\bar{e}$ geralmente difusa, raramente abrupta, e se dä por uma gradativa redução na dimensão dos cristais de quartzo feldspatos.

0 material resultante do intemperismo $\overline{\mathrm{e}}$ de um brạ co caracteristico, de composição caolinittica e contendo grãos de quartzo.

Composição

São rochas de composição extremamente simples, cons tituidas basicamente por quartzo e feldspatos, com concentrações principalmente de hornblenda e filmes de biotita. Entre os felds patos hă uma leve predomināncia do microclínio sobre o plagiocla sio, situação esta que se inverte prōximo aos contatos. Os acessōrios são: apatita, titanita, opacos e epídoto.

Descrição dos principais componentes

0 microciinio constitui cristais xenomörficos, irre gulares, tendendo a formas laminadas, com dimensöes frequentemen te maiores que $5,0 \mathrm{~mm}$. A geminação em grade $\bar{e}$ comum, assim como pertita em filme e veios. São frequentes as inclusões de plagiocläsio e quartzo arredondados, e mesmo de hornblenda. E comum - intercrescimento mirmequitico no contato entre microclínio e oligoclāsio, com quartzo vermicular estendendo-se praticamente por todo o cristal de oligoclásio.

o plagiocläsio, representado pelo oligocläsio, for ma cristais xenomörficos a irregulares, com dimensöes pouco meno res que os de microclínio. Encontra-se quase sempre desprovido de geminação, e invariavelmente com sinais de sericitização e pontos de epidotização. E pobres em inclusões.

0 quartzo ocorre sob a forma de cristais irregulares a ovalados, tendendo a formas laminadas, com dimensões muito variāveis, atingindo ate $4,0 \mathrm{~mm}$ ou mais, e raramente constituem leitos continuos. Caracteriza-se pela extinção ondulante. 0 contato entre os grãos vizinhos è suturado. Mostra-se frequentemen te fraturado e microgranulado. De modo geral, não apresenta in clusōes de outros minerais. 
A hoxnblenda constitui cristais prismāticos, com bordas irregulares e aspecto corroido. Pode atingir ate mais de $3,0 \mathrm{~mm}$ ao longo de $c$. Estā representada pela variedade verde, for temente pleocröica. Em certos locais ocorre em associação iatima com a biotita, podendo haver interpenetração mütua, com contatos nitidos, ou intercrescimento paralelo, com contatos difusos, o que denota sua passagem para biotita. Tambëm pode apresentar- se intercrescida internamente com clorita. São frequentes as inclu sões de quartzo e titanita.

A biotita ocorre sob a forma de cristais tabulares, quando intimamente associada à hornblenda, e constituīndo fiapos, quanto isoladas. Os cristais deformados encontram-se intensamente cloritizados. A biotita apresenta fraco pleocroismo e mastra disposição subparalela segundo $S$.

Como acessórios ocorrem a titanita subedral a anedral, com dimensões māximas de $0,5 \mathrm{~mm}$, preferencialmente inclusa nas bordas da hornblenda. Raros cristais pseudo-hexagonais de apatita e opacos aparecem disseminados em associação com biotita. 0 epidoto se apresenta como pequenos grãos arredondados, na maioria das vezes associados ao plagiocläsio e ä hornblenda.

\section{Considerações Finais}

Observando-se a localização destes tipos grosseiros na ärea, nota-se que eles ocorrem preferencialmente prōximo aos āpices de faixas dobradas, que representam äreas de maior aIĩvio de pressão. Macroscopicamente, nota-se a presença de concentrações de mäficos com contatos difusos em relação aos fēlsicos que apresentam textura pegmatitica. Os corpos são na maioria das vezes de pequenas dimensões e gradacionam lateralmente para rochas de granulação normal, ao mesmo tempo que parece haver um decrëscimo no teor de feldspato potässico.

Esses fatores, aliados à ausência de corpos magmäticos nas proximidades, sugerem, para esses gnaisses pegmatiti cos, uma origem a partir de uma segregação metamōrfica. Esta,por sua vez, seria acompanhada da migração local de ions de potāssio por meio de soluções que teriam fluĩdo de äreas de maior pressão com direção às de menor, devido a esforços compressivos durante uma fase de dobramento, acompanhada de recristalização. 
6. Biotita ( \pm granada) xistos

Generalidades

Estas rochas, embora pouco expressivas em volume, são comuns em grande parte da ārea abordada. Foram observadas as seguintes relações de campo:

- Lentes ou leitos intercalados. concardantemente com os biotita gnaisses, biotita-hornblenda gnaisses, quartzitos e märmores calcīticos, principalmente das associações litolögicas $(A),(B),(C),(D),(E)$ e (J) que abrangem a maior extensão da ärea em foco. Estas ocorrências são de espessuras reduzidas, nor malmente submëtricas e distribuỉdas irregularmente nas värias unj dades. Sö excepcionalmente, como na associação litolögica (E)cons tituida pelos biotita gnaisses com intercalações de anfibolitos e biotita xistos, alguns leitos atingem espessuras entre uma e duas dezenas de metros. Nesta unidade, as melhores exposições situam se no Cörrego do Cerro Azul, a SW da Fazenda do Bom Café. Entre outras, podem ser vistas boas exposições na Fazenda da Fortaleza, onde estas rochas ocorrem intercaladas com os märmores calcjticos.

- Constituindo alguns corpos mapeãveis a E e SE da ärea. Representam locais bastante intemperizados, com topografias que se destacam pela sua maior suavidade. o contato desses corpos com outras litologias pode ser tanto tectónico quanto transicional. No ültimo caso, a transição se dā, de modo especial, pela re dução da biotita e enriquecimento em feldspatos. Alguns afloramen tos pouco alterados podem ser observados no corpo situado a $E$ da Serra dos Coutos, jă no Estado de Minas Gerais.

Nomenclatura

A classificação destas rochas como xistos, foi baseada na nomenclatura apresentada por Winkler (1976, pp. 326), on de os filossilicatos constituem mais de $50 \%$ da rocha e os feldspa tos menos de $20 \%$, alëm de sua tipica clivagem xistosa.

Descrição macroscōpica

Os biotita xistos caracterizam-se pelo acentuado de 
senvolvimento da estrutura xistosa, que thes imprime feições onduladas e corrugadas. São rochas cinza escuras ou cinza esverdea das, exibindo granulação de mëdia a grossa. Alguns leitos ricos em metablastos de granadas com atē mais de $1,0 \mathrm{~cm}$ de diāmetro, fo ram observados unicamente no corpo a $E$ da Fazenda dos Coutos, ao longo da estrada que leva para a referida Fazenda.

Sempre acompanhando a xistosidade destas rochas, $\bar{e}$ comum a ocorrēncia de leitos de quartzo de segregação metamōrfica, com espessuras variando desde $1-2 \mathrm{~cm}$ atē quase uma dezena de centimetros. Estes leitos pode se apresentar lentiformes e re gulares, continuos ou esparsos e, muitas vezes, com microdobramentos e "boudinage".

Acompanhando ou não a xistosidade e como uma conse quência da segregação metamōrfica, encontram-se ainda em certos locais, leitos pegmatiticos de 5 a $20 \mathrm{~cm}$ de espessura, contendo quartzo, feldspatos e biotita.

0 material de alteração intempērica $\bar{e}$ de cor verme Tha e às vezes com tonalidades amareladas, predominantemente argiloso e um tanto rico em grãos de quartzo.

\section{Composição e Textura}

A composição dos biotita xistos ē relativamente simples, predominando amplamente a biotita entre os mäficos, po dendo em muitos casos ser o ünico mäfico presente. A hornblenda, tambēm bastante comum, apresenta teores muito variāveis, podendo mesmo estar ausente. Localmente, ocorrem alternāncias continuas entre leitos milimétricos de biotita e de hornblenda. Entre os fēlsicos o quartzo $\overline{\mathrm{e}}$ o mineral principal, sendo o feldspato representado essencialmente pelo plagiocläsio e raramente pelo mi croclinio. Ocorrem ainda granada, opacos, titanita, apatita e epidoto.

No seu conjunto, a textura destas rochas ē lepidoblästica, porém as zonas mais quartzosas, quando examinadas ind vidualmente, mostram seu caräter granoblästico. Textura porfiroblästica $\vec{e}$ de carater local e restrita e alguns leitos com fenoblastos de granada, no corpo a $E$ da Fazenda dos Coutos. Em quase todas as amostras examinadas a biotita mostra-se frequentemen 
te esmagada e o quartzo com acentuada recristalização e deforma ção.

\section{Descrição dos principais componentes}

A biotita estā representada principalmente por cristais tabulares, com dimensões bastante variāveis, podendo atingir atē $2,0 \mathrm{~cm}$, mas em mëdia entre $0,4 \mathrm{e} .0,7 \mathrm{~mm}$. Fortemente pleocröica, com X - castanho-amarelado e Z - castanho-escuro. Na presença da textura porfirobiástica, a biotita amolda-se ao redor dos metablastos de granada e exibe-se sob a forma de fiapos de tamanho variāvel, frequentemente deformadas.

Algumas vezes, a biotita ocorre intercrescida transversalmente com a hornblenda, o que pode indicar uma certa recristalização pōs-tectōnica. Nas ocorrēncias ricas em hornblen $\mathrm{da}$, ê frequente uma acentuada biotitização deste mineral. Observam-se todas as passagens entre uma reação incipiente e uma transformação quase total da hornblenda em biotita. A biotita neo-formada apresenta menor pleocroismo e formas mais irregula res. Este fenōmeno foi observado em amostras provenientes princi palmente de leitos xistosos, situados ao $S$ da Fazenda da Fortale za.

O intercrescimento paralelo com a clorita $\bar{e}$ pouco pronunciado. Subordinadamente, as biotitas se mostram orientadas segundo duas direções, com um āngulo de aproximadamente 300 enm tre si.

E um mineral pobre em inclusões, podendo apresentar pequenos cristais de hornblenda, titanitas euedrais, principalmente nas biotitas cloritizadas, e opacos sob a forma de pequenos grãos disseminados.

A hornbzenda constitui normalmente cristais de häbito lamelar, com dimensöes que podem ultrapassar 4,0 mm na sua maior extensão. E representada pela variedade verde, de forte pleocroĩsmo. Pode apresentar inclusões de quartzo arredondado e menos frequlentemente grãos de plagiocläsio, apatita e titanita.

A granada, de um vermelho vivo em amostras de mão, mostra tons rosados em secções delgadas. E um mineral raro, ocor rendo principalmente sob a forma de pequenos cristais geralmente 
euedrais, arredondados, contendo ou não inclusões. Localmente, co mo no corpo situado a $E$ da Fazenda dos Coutos, ocorre sob a forma de fenoblastos arredondados, atingindo até mais de $1,0 \mathrm{~cm}$ de diâmetro. A granada ocorre concentrada nos leitos mais biotiti cos e os seus fenoblastos geralmente deslocam a biotita que então se amolda ao seu redor. Raramente inclui parte de biotita. Ao longo das fraturas das granadas ocorrem, com freqüencia, finos veios de clorita, tornando-se dificil estabelecer se trata-se de fenômenos de intemperismo ou de reação metamōrfica.

0 quartzo, quase sempre recristalizado, $\overrightarrow{\mathrm{e}}$ xenoblās tico, com formas irregulares, amebóides ou mesmo laminados, exibindo em todas as formas a extinção ondulante. Estes ūitimos,qua se sempre com bandas de deformação e bordas serrilhadas, atingem dimensões atē centimëtricas. Gräos recristalizados com extinção ondulante implicam em, pelo menos, duas fases de deformação tectônica, uma levando à formação dos metablastos e a outra deformando-os. Nos cristais maiores, o quartzo engloba pequenas lamelas de biotita ao recristalizar.

Entre os fezdspatos predomina o plagioclāsio do ti po oligocläsio cālcico. Estes são xenomörficos com dimensões mēdias de $0,5-0,6 \mathrm{~mm}$ e quase sempre desprovidos de geminação. Em certos locais, mostram acentuada serecitização e pontos de epido tização. Apresentam inclusões de quartzo arredondado e raros cristais de biotita e hornblenda principalmente nas bordas. 0 mi crociinio e bastante raro e constitui cristais anedrais de peque nas dimensões, associados aos leitos mais quartzosos. Podem ou não apresentar geminação e são pobres em inclusões.

A titanita ocorre como cristais euedrais ou disseminadas em pequenos grānulos. Os cristais maiores chegam a atingir atē $1,0 \mathrm{~cm}$ e estão freqüentemente associados à biotita ou à hornblenda. Os opacos são abundantes, exibindo formas irregula res, esquelēticas e grãos disseminados associados principalmente à biotita. 0 epidoto, na forma de pequenos grãos arredondados,ocorre principalmente como produto da transformação do plagiociäsio e subordinadamente da hornblenda. A apatita $\vec{e}$ de ocorrência restrita.

Natureza pré-metamörfica

A natureza destas rochas, representada pela alta 
percentagem de biotita associada ao elevado teor de quartzo, não deixa dūvidas quanto à origem sedimentar prē-metamōrfica para os biotita xistos. A presença de faixas com teores variāveis de hornblenda, indica que estas rochas se formaram como produto do metamorfismo regional agindo sobre rochas peliticas com porcões de grauvacas.

7. Quartzitos

Generalidades

Em grande parte da ārea abordada, ē comum a ocorrēn: cia de quartzitos mais ou menos feldspäticos. Estão distribuidos da seguinte forma:

- Constituindo numerosas lentes ou leitos de dimen sões variäveis, de decimëtricas a mētricas, encaixadas concordan temente com os biotita e hornblenda gnaisses do arcabouço. Estas são abundantes nas associações litolögicas (B) e (D),estando pra ticamente ausentes nas demais. Pelas suas dimensões não foram re presentadas na carta geolögica, mas incluĩdas na associação lito lögica da unidade correspondente.

- Constituindo horizontes mais ou menos continuos, que vão desde algumas dezenas atē uma centena de metros de espes sura, ritmicamente intercalados com as rochas do arcabouço. Esses horizontes são concordantes com a estrutura regional e paralelos entre si. Devido à sua maior resistência ao intemperismo sobressaem na topografia, chegando a desenvolver serras escarpadas nos leitos mais possantes.

As ocorrēncias mais expressivas estão representadas respectivamente por uma faixa continua com disposição geral $N E-S W$, na parte $N-N W$ da ärea, e na sequéncia dobrada representan do o nariz do sinclinal a E-NE da cidade de Itapira. Alëm destas, estão presentes värias outras seqüências de maior ou menor : expressão, tambëm representadas no mapa geolögico-estrutural anexo, que guardam estreita relação com determinadas associações $1 \underline{i}$ tolögicas, no caso, principalmente as representadas pelas associações (B) e (D).

Os quartzitos freqüentemente mostram boas expos 
ções. Dentre elas podemos citar a situada logo à esquerda da rodovia Mogi-Mirim-Itapira, cerca de 1 quilometro da borda leste da ārea; as presentes na rodovia Itapira-Jacutinga; em: muitos trechos das estradas de fazendas que cortam perpendicularmente as estruturas da sequéncia dobrada a NE de Itapira, bem como em muitos trechos de quase todas as estradas de terra que cortam a faixa situada a $N-N W$ da àrea.

A taxa de quartzitos sofre uma redução progressiva de oeste para leste, fato este confirmado tambëm por incursões realizadas alēm da ārea mapeada, o que vem corroborar as afirmações de Wernick (1967) e Wernick e Penalva (1973).

\section{Relação de contato}

Invariavelmente, tanto os leitos delgados quanto os horizontes mais possantes acham-se dispostos concordantemente com os gnaisses fitados e bandeados. No campo, observa-se uma ni tida passagem gradativa entre os quartzitos e os gnaisses do arcabouço, que se dá pelo surgimento e/ou incremento principalmente de biotita e feldspatos, e desaparecimento progressivo da mus covita nos quartzitos portadores deste mineral. Muito raramente - contato é abrupto, podendo no entanto a sequéncia ser interrom pida muitas vezes por falhamentos. Fato curioso foi notado com relação aos horizontes mais espessos, que, muitas vezes, apresen tam lateralmente intercalações quartzïticas com espessuras cada vez mais reduzidas, refletindo uma transição, em escala maior, das faixas quartzosas para os gnaisses. Nestes casos a distribui ção dos leitos não è simētrica, estando os horizontes mais possantes deslocados para um ou para outro lado.

0 contato de transição pode ser observado, tambēm no sentido longitudinal, nos corpos não interrompidos tectonicamente. Assim nos corpos situados ao sul, a leste e a noroeste de Itapira, bem como o corpo localizado na metade inferior do mapa, a leste da Fazenda do Jardim, os horizontes ou leitos vão sofren do redução nas suas espessuras até diluirem-se nos gnaisses do arcabouço. 
Tendo em vista os contatos gradacionais com os : outros tipos litolōgicos e a heterogeneidade apresentada por estas rochas na sua composição, incluĩmos sob o termo quartzito todas as rochas contendo mais de $60 \%$ de quartzo. A determinação de tal porcentagem foi realizada de forma estimativa, tanto no campo como no laboratōrio, em amostras de mão e secções delgadas.

\section{Descrịção}

Os quartzitos da região de Itapira apresentam aspec tos gnäissicos e caracterizam-se pela heterogeneidade, tanto no tocante à composição quanto à granulação. Assim ocorrem quartzitos puros, representando a fração menor, ocupando normalmente as partes centrais dos horizontes mais espessos; muscovita quartiitos, como os tipos litológicos mais frequentes, podendo ou não ser feldspāticos, e biotita quartzitos feldspäticos com ou sem muscovita. Estes ūttimos foram verificados nas zonas de transição com os gnaisses. Nos quartzitos feldspāticos o teor do feldspato varia de leito para leito, podendo corresponder ao componente mais importante. Os leitos são de dimensões variāveis, desde centime-tricos a mëtricos, e a granulação varia de fina a grossa. A musco vita, mineral freqliente, ocorre em linhas milimëtricas descontinuas, orientadas sub-paralelamente ressaltando a foliação. 0 espa çamento dessas linhas de muscovita $\vec{e}$ bastante variāvel, desde cer rada atē dezenas de centímetros.

A cor tambëm ë muito variävel, ocorrendo tanto tipos esbranquiçados, quanto cinzentos e amarelados. Os termos alte rados apresentam-se manchados devido à alteração do feldspato.como efeito da milonitização, que muitos quartzitos exibem, são comuns os termos vĩtreos. Estes quanto decompostos, dão origem a um material quartzoso muito fino. E o caso de certas faixas quartziticas situadas no corpo a NW da ārea, prōximo ā zona de transcorrência de Jacutinga mais intensamente afetadas pelo tectonismo.

\section{Textura e mineralogia}

Os quartzitos apresentam textura granoblästica elongada (Spry, 1974, pp. 263), resultante de uma recristalização total do quartzo que deve ter-se processado por um longo perĩodo 
de tempo, sob influēncia de esforços de compressão. o desenvolvimento subparalelo dos cristais alongados de quartzo reflete a foliação apresentada por estas rochas. Por outro lado, estas litolo gias exibem, com frequēncia, um acentuado efeito cataclāstico pōs cristalino com incipiente recristalização, evidenciado principalmente por grãos de quartzo com extinção ondulante, fraturas, zonas de esmagamento com grãos laminados e textura em pacote (Micro foto 5), alëm de muscovitas sob a forma de fiapos.



Microfoto 5 - Muscovita quartzito com grãos de quartzo fraturados, extinção ondulante e bandas de deformação. Nicois $x$, aumento $10 x$.

Como mencionado, os quartzitos são rochas constituj das predominantemente por quartzo, podendo, em muitos casos, ser - único mineral presente. Os feldspatos são representados, tanto pela variedade potässica, sob a forma de microclīnio, quando södi co-cālcica sob a forma de oligoclásio bāsico. observa-se a presen ça generalizada de muscovita em quantidades variāveis, nunca uttrapassando a $10 \%$ do total das amostras. Como acessörios ocorrem ainda: biotita, restrita às faixas de transição dos quartzitos,opacos, zircão e epĩdoto.

0 quartzo, fortemente recristalizado, è quase sem- 
pre alongado, com dimensões mëdias entre 0,7 a $0,9 \mathrm{~mm}$ segundo a maior extensão, podendo localmente atingir dimensões centimētricas em grãos laminados. Os contatos entre grãos vizinhos são ser rilhados a suturados, podendo mesmo ser sub-planares com frequen tes junções de pontos tríplices. Cordões de inclusões, aproximadamente perpendiculares à maior dimensão, são localmente comuns, devendo ser interpretados como fraturas cicatrizadas

(Tutt) , 1949), correspondendo à deformação para-cristalina. A frequlente presença de extinção ondulante e de grãos deformados indica que os quartzitos sofreram deformações pōs-cristalina.

$0 \mathrm{~s}$ cristais de quartzo apresentam comumente inclu sões de minūsculas lamelas de muscovita, iso-orientadas paralela mente à sua maior extensão, e raros opacos disseminados.

0 oligocläsio constitui cristais anedrais sub-arredondados, quase sempre desprovidos de geminação, intensamente sericitizados e frequlentemente epidotizados. São raras as inclusões de quartzo arredondado.

0 microclinio, em cristais anedrais irregulares a subarredondados, mostra discreta geminação cruzada, compondo,jun tamente com o oligoclásio, os leitos feldspáticos. 0 tamanho dos grãos dos feldspatos é mais ou menos igual e normalmente maior que o do quartzo. O microclinnio è pouco pertītico e pobre em inclusões.

A muscovita ocorre na forma de delgadas lamelas alongadas, constituíndo pequenos agregados isomorientados, exibin do frequlentemente duas direções. A direção paralela à foliação geral dos quartzitos $\vec{e}$ inteiramente predominante. A segunda orientação forma com a primeira āngulos normalmente em torno de 300. A intensidade e dimensão das lamelas variam segundo a localização geogräfica das amostras examinadas. Assim, a oeste, são mais abundantes e de maiores dimensões, podendo atingir 3 a $4 \mathrm{~mm}$, diminuindo de intensidade e tamanho para leste, onde culmi nam com minúsculas lamelas que dificilmente ultrapassam a $0,3 \mathrm{~mm}$. De modo geral, exibem major ou menor efeito de esforços tectônicos, apresentando-se curvadas, fraturadas, cisalhadas e mesmo re duzidas a fiapos.

A biotita ocorre praticamente restrita aos leitos de transição dos horizontes mais espessos de quartzitos para os 
gnaisses. Mostra-se tectonicamente esmagada e intensamente cloritizada. Os acessórios são representados pelos opacos, em grãos alongados ou esquelēticos associados predominantemente $\bar{a}$ : muscovita, pelo epídoto, disseminado no oligocläsio, e por, raros cristais ovais a arredondados de zircão.

\section{Natureza prë-metamōrfica}

Como descrito anteriormente, nota-se que estas rochas apresentam uma sērie de características, quais sejam:

- presença ou ausência de feldspatos;

- leitos com teores variäveis em feldspatos;

- aparecimento mais ou menos generalizado de muscovita;

- contatos geralmente gradacionais com os biotita e hornblenda gnaisses, com os quais exibem nitida ritmicidade.

Estes dados sugerem que o material prē-metamörfico era constituido por arenitos mais puros alternados com leitos de arenitos feldspāticos, ambos com matriz pouco argilosa e interaca mados com espessas sequencias areno-peliticas impuras.

\section{Anfibolitos}

Generalidades

Em toda ārea estudada, ē comum a ocorrēncia de anfí bolitos que guardam as seguintes relações de campo:

- Anfibolitos cortando as outras rochas metamörf cas. São pouco expressivos e raros, sendo observados geralmente compondo corpos tabulares com espessuras inferiores a um metro. As melhores exposições situam-se ao sul da Fazenda do Bom Cafē, na estrada de terra que liga esta ā Fazenda Santa Maria; a NE: da ärea, e na rodovia Itapira-Lindōia, na Fazenda Cristälia, em fren te à Clínica de Repouso.

- Corpos concordantes ou ligeiramente discordantes, geralmente tabulares embutidos em outras rochas metamörficas. Os 
jazimentos são de dimensões muito variāveis, desde poucos decỉme tros a värias dezenas de metros de espessura e estendem-se por ate värias centenas de metros. Estes corpos apresentam contatos bruscos em relação às outras rochas, com exceção de um corpo em forma de lente, situado no $\mathrm{km} 34$ da Rodovia Itapira-Lindöia, que gradaciona para hornblenda gnaisse. A concentração destes anfibo litos, na ārea, ē muito variāvel. Assim, em certos locais . são bastante raros, enquanto que em outros ocorrem em quantidades razoāveis. Tambēm parecem diminuir em intensidade tanto de sul para norte quanto de oeste para leste, a partir das imediações de Itapira. Concentrações particularmente grandes encontram- se ao sul da rodovia Itapira-Lindōia, à esquerda do Ribeirão da Penha; ao sul da Fazenda do Jardim, pröximo à parte terminal do na riz do sinclinal a NE de Itapira, e imediatamente ao $N$ da pedre ra localizada na Fazenda da Fortaleza. Bonitas exposições indivi duais de corpos tabulares podem ser observados na rodovia Itapira-Lindōia, onde o Rio do Peixe se aproxima pela primeira vez da rodovia, no $\mathrm{km} 35,3$, e na mina situada a $W$ da Fazenda Cristalia, alēm de numerosas outras ocorrências.

\section{Descrição macroscōpica}

Os anfibolitos são rochas densas, verde escuras, de grã variāvel entre fina e mëdia, sendo esta predominante. Raras vezes observa-se uma mudança da granulação numa mesma amostra. Quando intemperizados exibem cor verde amarelada ou ocre caracte rística. A textura è predominantemente nematoblästica e a estrutura freqlientemente $x$ istosa, principalmente nos termos mais ricos em hornblenda.

\section{Descrição microscōpica}

dois grupos:

Os anfibolitos examinados podem ser separados em
A. Andesina anfibolitos
B. Diopsídio andesina anfibolitos

A. Andesina anfibolitos 
Estas rochas exibem, de modo geral, grande homoge neidade nas caracterīsticas mineralōgicas em toda a ārea estuda da. São rochas de textura granoblāstica, observando-se quase sem pre vestīgios de uma textura granular prē-metamōrfica (Microfoto $6)$.

São compostos essencialmente por hornblenda e plagioclāsio. A hornbzenda é fortemente pleocrōica com X-verde amare 1o, Y-verde castanho ou verde e Z-verde. 0 teor de hornblenda varia aproximadamente entre 45 e $70 \%$. Constitui cristais subedrais e anedrais, estes subordinadamente de tamanho constante entre 0,4 e $0,5 \mathrm{~mm}$ ao longo de $c$. Em alguns casos o tamanho dos cristais de hornblenda pode variar de leito para leito, (Microfoto 7.). Estes cristais apresentam-se iso-orientados. Inclusões, geralmente de opacos, e intercrescimento com plagioclāsio são raros. Quan do ocorre clorita, este mineral exibe relações de reação com a hornblenda.



Microfoto 6 - Andesina anfibolito, notando-se vestigios de textura granular. Nicois//, aumento $25 x$.

0 plagioclásio è o segundo mineral em importāncia, podendo mesmo tornar-se o mais freqliente.'O tipo de ipragiociásio 




Microfoto 7 - Andesina anfibolito. Contato entre leitos de cristais grandes e pequenos de hornblenda. Nicois//, a $\underline{u}$ mento $10 x$.

varia aproximadamente entre oligoclāsio bāsico e andesina bāsica, mas com predominância em andesina ācida. Com frequência, o plagio clāsio se mostra sericitizado, principalmente nas amostras portadoras de clorita, e quase sempre geminado segundo a lei Albita. In clusões são raras. 0 contato com hornblenda e andesina dā-se por justaposição ou raramente por intercrescimento.

0 quartzo constitui cristais anedrais, exibindo fra ca extinção ondulante. Seu teor é muito variāvel, sempre inferior a $10 \%$, podendo mesmo estar ausente. Quando falta geminação no pla gioclásio, os cristais diminutos facilmente se confundèm com os do quartzo.

A clorita estā presente em raros casos. Pleocroísmo intenso com X-verde amarelo e Z-verde vivo. Extinção reta e cor de birrefringência anômala cinza-azul clara. A clorita forma, em alguns casos, grandes metablastos de disposição radial. Pequenas inclusões de titanita são raras.

0s cristais de epidoto são raros, anedrais, verde amarelados, fracamente pleocróicos e mostram cores de birrefrin 
gência anômalas. Ocorrem quase sempre associados à hornblenda em amostras com plagioclásios sericitizados. Não se pode estabelecer com precisão se o epīdoto faz parte da paragēnese primāria ou se corresponde a um mineral originado da transformação da hornblenda.

Titanita e opacos ocorrem em teores variāveis, ten do sido observados anfibolitos praticamente isentos destes minerais, anfibolitos portadores somente de titanita ou somente de opacos e anfibolitos apresentando os dois minerais.

0s opacos ocorrem quase sempre sob a forma de cris tais anedrais, e, em alguns casos, com formas esquelēticas atingindo atē $1,0 \mathrm{~mm}$. Entre a titanita formas euedrais são comuns.

Sericita é muito rara, sendo proveniente da transformação do plagioclāsio.

\section{B. Diopsĩdio andesina anfibolitos}

Estão presentes em nümero muito inferior ao dos andesina anfibolitos, e estão aparentemente restritos a algumas ocorrências a oeste e sudoeste da Fazenda Cristāita.

os diopsídios-andesina anfibolitos diferem dos anteriores apenas pela presença de um piroxênio neutro ou levemente esverdeado. Os cristais são subedrais e anedrais e ligeiramen te maiores que os de hornblenda. Esta é a mesma dos andesina anfibolitos. 0 plagioclāsio estā representado essencialmente pèra andesina ācida. Sericitização e geminação segundo a lei da Albita são comuns. Quartzo ocorre em teores variāveis, sempre em pequenos cristais anedrais. Epĩdoto e clorita não foram verificados. Titanita e opacos são raros, ocorrendo sob a forma de diminutos cristais ovalados a irregulares. Microclínio, constituīndo raros cristais irregulares, só foi encontrado em uma amostra na mina, a E da Fazenda Cristälia.

A textura dos diopsīdio-andesina anfibolitos è mais irregular que a dos andesina anfibolitos. A disposição dos cristais é mais caōtica e os contatos são mais irregulares.

A principal caracteristica destas rochas consiste na transformação do diopsỉdio em hornblenda. A reação pode 
iniciar-se tanto nas bordas quanto no interior do piroxênio. Geralmente ocorrem vārios nücleos de reação dispostos freqüentemen te ao longo de planos de clivagem do diopsidio. Esta transformação ē acompanhada pela sericitização do plagioclāsio.

\section{Material prē-metamörfico dos anfibolitos}

Tanto os anfibolitos concordantes quanto os discor dantes caracterizam-se por uma composição mineralōgica bastan te homogēnea, granulação predominantemente fina a mëdia e por vestigios de textura granular prë-metamörfica. Estes fatores adicionadas aos contatos essencialmente abruptos ém relação às ou tras rochas, permitem considerā-las como correspondendo ao produ to metamörfico de lavas ou rochas hipo-abissais bäsicas da fase ofiolitica do ciclo orogenētico.

\section{Gonditos}

\section{Generalidades}

Embora os gonditos apareçam como integrantes de vārias unidades 1 itolōgicas que abrangem a maior extensão da ārea mapeada, eles são mais frequentes a $W$, a $S$ e SW da ärea,sen do relativamente raros nas partes centro-norte e centro-leste. Apresentam a seguinte distribuição:

- Constituindo na maioria das vezes diminutos leitos ou corpos lenticulares com espessuras desde centimētricas a mētricas, encaixadas concordantemente nos muscovita quartzitos 'e biotita gnaisses. Estes tipos de jazimentos estão presentes, em ordem decrescente de frequência,como integrantes das associaçöes litolögicas (A), (D), (C) e (B). A distribuição destes gonditos dentro de uma mesma unidade ē bastante heterogênea, constituíndo normalmente äreas de concentrações que, devido às suas reduzidas espessuras, são pouco expressivas. As melhores exposições situam se na Rodovia Itapira-Lindōia, logo depois do trevo de Amparo, e em vārios pontos da antiga estrada que liga Itapira a Mogi-Mirim, entre Itapira e as rochas da Bacia do Paranā.

- Concentrações de horizontes relativamente possan 
tes, com espessuras de algumas dezenas de metros, atingindo ... no mäximo cerca de $50 \mathrm{~m}$ de espessura, como no corpo situado mais ao sul da ārea e a SE da Fazenda do Retiro. Estas concentrações estão representadas na carta geológica, sendo que as localizadas a SE de Itapira apresentam-se intercaladas concordantemente nos biotita gnaisses fitados e bandeados da associação litolögica (A), e as situados a NW de Itapira estão encaixadas em muscovita quartzitos e biotita gnaisses da associação litolögica (D). Estes $\bar{u} 1$ timos foram estudados por Wernick et al. (1976a) e são de caracterização mais dificil dada a ausēncia de bons afloramentos. Essas ocorrēncias refletem dois horizontes descontinuos com dire ções gerais respectivamente NE-SW e NW-SE.

Tanto os gonditos constituintes dos leitos ou len... tes de espessuras reduzidas quanto os dos horizontes mais espessos, gradacionam lateralmente para as rochas encaixantes. A tran sição para os biotita gnaisses se dā pelo incremento sucessivo de feldspato e biotita, e, para os quartzitos, via granada quart zitos, estando estes, por sua vez, intercalados concordantemente nos biotita e hornblenda gnaisses. As lentes gonditicas-quartziticas mais possantes ressaltam na topografia como pequenas serras retilineas, mais resistentes à erosäo.

\section{Descrição macroscōpica}

Os gonditos são rochas compostas essencialmente por quartzo e granada. São caracterizados por uma estrutura ritmica, persistente, com leitos de espessura variävel, geralmente centimëtricos a decimëtricos, ora predominantemente quartziticos, ora muito enriquecidos em granada, ou de composição mista. A gra nada $\bar{e}$ vermelha-rōsea ou vermelha-castanha, enquanto o quartzo $\bar{e}$ quase sempre cinzento. A granulação varia de fina a média, poden do localmente ocorrer concentrações de cristais de granada euedrais subcentimētricos. Estas rochas mostram-se quase sempre alteradas para um material quartzoso, pulverulento, rico em öxidos e hidröxidos de manganēs.

\section{Descrição microscōpica}

Os gonditos são de composição muito simples, cons- 
tituídos essencialmente por granada e quartzo. Raramente ocorrem associados magnetita e plagioclāsio. As rochas ostentam textura granoblästica, predominantemente eqüigranular, tanto de mosaico quanto por interpenetração do tipo serrilhado, predominando esta nas rochas ricas em quartzo e aquela nas mais ricas em granada.

0 quartzo ocorre:normalmente constituindo cristais pequenos, arredondados, de granulação constante, ao redor de $0,1 \mathrm{~mm}$, com contatos geralmente por justaposição. Nos leitos mais ricos em quartzo, este é ovalado, com extinção ondulante, contatos denceados e medindo em mëdia $0,4 \mathrm{~mm}$. Encontram-se frequentemente esmagado, com formas alongadas, intensamente fratura do e parcialmente recristalizado. Nos leitos mais ricos em grana da o quartzo assume forma intersticial.

A granada ostenta dimensões variāveis, de leito para leito, podendo localmente atingir alguns milimetros de diāmetro. As formas anedrais predominam amplamente e nos cristais maiores são comuns as inclusões de quartzo. As granadas tambëm exibem deformação de grau variāvel, evidenciada pela sucessão de leitos microscōpicos a centimētricos constituídos por: grana das sem fraturas; granadas com fraturas fechadas; granadas com fraturas abertas e preenchidas por quartzo; e granadas fragmenta das, onde o cristal original $\bar{e}$ dividido em numerosos fragmentos angulosos e cimentados por quartzo.

Sob a ação do intemperismo a granada libera uma mistura de öxidos e hidrōxidos de manganês. observações microscō picas revelam que o processo se inicia ao.longo das fraturas: e zonas de esmagamento nas granadas. Os produtos tiberados propagam-se pelas rochas, ao longo das fissuras existentes nos mine rais, constituindo pequenos veios, ou ao longo dos contatos entre os grãos de quartzo.

Wernick et al. (1976a) determinaram, para os gonditos de Socorro e Itapira, as seguinte composição em granadas: $41 \%$ de espersatita, $34 \%$ de almandina e $25 \%$ de piropo. Verificaram, tambēm, ampla variaçăo no teor de manganês, de $7,14 \%$ a $29,89 \%$, se bem que, localmente, possa atingir concentrações de $53 \%$ de manganēs metālico. Estes valores são comparāveis aos dados fornecidos por Pires et al. (1970) para ocorrências semelhan tes na região de Careaçu (MG), cujos minërios mais ricos ostentam teores entre $32,3-47 \%$ de manganês. 
0correm ainda, subordinadamente, cristais subedrais de magnetita, de tamanho variävel entre 0,01 e $0,5 \mathrm{~mm}$, quase sempre isolados, e raros cristais anedrais de plagiocläsio (andesina cälcica (?) sericitizado.

\section{Natureza prë-metamörfica}

os leitos, lentes ou horizontes dos gonditos compos tos essencialmente pelo quartzo e granada, associados aos quartzitos e biotita gnaisses fitados e bandeados do arcabouço rocho so, com as quais exibem contatos predominantemente transicionais, indicam que os gonditos são rochas resultantes do metamorfismo re gional sobre arenitos manganesíferos.

\section{Märmores Calcïticos}

\section{Ocorrēncia}

As rochas carbonäticas estão restritas a duas ocorrēncias pouco expressivas inseridas nos biotita e ?hornblenda gnaisses do arcabouço rochoso. A principal delas localizada na Fa zenda da Fortaleza, a leste da ärea, constitui um corpo de forma lenticular compostos por quatro leitos, intercalados com biotita xistos. O major deles chega a atingir cerca de $15 \mathrm{~m}$ de espessura. No mesmo corpo ocorrem outros leitos descontĩnuos de dimensões desprezĩveis. Os contatos dos märmores com os metamorfitos são abruptos. Esta ocorrēncia encontra-se em exploração hä mais: de duas dēcadas.

A outra ocorrência ē representada por apenas dois leitos respectivamente com cerca de 1 e 2 metros de espessura e com aproximadamente uma dezena de metros de extensão. Situa- se às margens do Cörrego da Mata, no limite dos Estados de São Paulo e Minas Gerais, ā leste da ārea. Ela foi explorada e atualmente encontra-se abandonada devido à reduzicia quantidade das rochas carbonaticas.

Caracteres Texturais e Estruturais 
sentando-se de modo geral com coloração branca homogênea a branca acinzentada. A fratura e predominantemente conchoidal a plana ou irregular. A superficie da rocha mostra aspecto sacaróide e a coe rência entre os grãos é muito forte.

Estruturalmente, os märmores são concordantes com os demais metamorfitos, exibindo, em escala de afloramento, um va go bandeamento com espaçamento irregular. Em amostras de mão, são relativamente homogêneos, mostrando, às vezes, uma discreta folia ção perceptĩvel pela variação no tamanho dos grãos.

Microscopicamente, os märmores mostram uma textura predominantemente granoblästica mëdia, com arranjo em mosaico, granulometria relativamente homogênea, fortemente recristalizada, e com tamanhos compreendidos entre 0,5 a $2,0 \mathrm{~mm}$, esporadicamente atingindo $0,3 \mathrm{~mm}$. São comuns evidências de deformações tectōnicas, produzindo localmente deligados leitos descontīnuos de esmagamen tos e parcialmente recristalizados.

As implicações intergranulares normalmente são sutu radas, raramente planas, com moderada a forte imbricação e interpenetrações superficiais atē profundas (mais comuns) dos cristais.

\section{Mineralogia}

Os märmores são de natureza calcītica, com teores entre $\mathrm{T}$ e $2 \%$ de MgO (informação verbal da Mineração Fortaleza), a presentando boa efervescencia ao äcido clorídrico diluĩdo. A composição mineralögica destas rochas è extremamente simples, sendo constituida essencialmente pelos minerais carbonäticos. 0s minerais de quartzo, flogopitta, tremolita e talco perfazem 1 a $2 \%$ do total.

Os grãos dos carbonatos (calcita e dolomita). são normalmente anēdricos, raros subēdricos, com bordas irregulares. Macroscopicamente, são de coloração branca e incolor, localmente acinzentados, e microscopicamente ligeiramente turvos. os cris tais de calcita apresentam-se comumente microfraturados, com maclamentos polissintéticos finos, geralmente deformados e encurvados.

0 quartzo, em quantidades bastante reduzidas, cons- 
titui pequenos grãos arredondados ou levemente alongados e raros anëdricos. E incolor e lïmpido, estando a extinção ondulante qua se sempre presente. ocorre disseminado na rocha ou preenchendo vênulos, juntamente com os carbonatos.

A flogopita, na forma de delgadas lamelas incolo res com dimensōes mäximas de $0,4 \mathrm{~mm}, \vec{e}$ relativamente comum em uma das amostras examinadas. 0corre iso-orientada principalmente ao longo das interfäcies dos carbonatos, acentuando a discreta foliação apresentada por estas rochas. Localmente as palhetas de flogopita mostram duas orientações, formando, com a orientação principal, um ângulo de aproximadamente 30 .

A tremolita $\bar{e}$ muito rara, ocorrendo sob a forma de pequenos cristais fibrosos, incolores a levemente esverdeados.

0 talco, tambëm raro, constitui agregados mais ou menos circulares, lembrando flocos, dispersos na massa carbonāti ca, com dimensões entre 0,2 e $0,3 \mathrm{~mm}$. E acinzentado e com $2 \mathrm{~V}$ pra ticamente de 0 .

Natureza prë-metamörfica

A presença de leitos de märmores calciticos, inter calados predominantemente com biotia xistos,sugere, para estas rochas, uma origem prē-metamōrfica representada por uma sequén cia de calcärios relativamente puros intercalados com material pelítico.

11. Meta-hornblenditos e -ultramafitos

Generalidades

Os meta-hornblenditos e meta-ultramafitos ocorrem constituindo concentrações locais de corpos tabulares ou lenticu lares, embutidos tanto concordantemente quanto discordantemente nos biotita e hornblenda gnaisses, com os quais exibem contatos iminentemente abruptos. De modo geral, são relativamente raros na ärea estudada, tendo sido observadas cinco concentrações respectivamente a NE da ārea, logo ao nortedo rio do Peixe; a NE de Itapira, pröximo ao Rio do Peixe; a NE da Fazenda da Fortale- 
za; a W-SW da Fazenda Cristälia e W da Fazenda Santo Antonio. Os meta-hornblenditos são muito mais frequlentes que os meta-ultrama fitos. Os jazimentos são de dimensões muito variāveis, normalmen te entre poucos decimetros a alguns metros de espessura, e s $\overrightarrow{0}$ muito raramente atingem algumas dezenas de metros. Estendem- se por mais de uma centena de metros. Os jazimentos mais expressivos de meta-hornblenditos ocorrem nas duas concentrações situadas a NE de Itapira, entre a rodovia Itapira-Jacutinga e o Rio do Peixe.

Os meta-ultramafitos ocorrem associados aos metahornblenditos nas concentrações a NE da Fazenda da Fortaleza e a W-SW da Fazenda Cristälia, predominando os primeiros. Na ūltima concentração estä sendo atualmente explorado amianto.

os meta-hornblenditos e meta-ultramafitos da ārea de Itapira podem ser agrupados nos seguintes tipos litolögicos:

A. Meta-hornblenditos

A.1. Meta-hornblenditos propriamente ditos

A.2. Diopsidio meta-hornblenditos

B. Meta-ultramafitos

B.1. Meta-piroxenitos

B.2. Meta-peridotitos

Descrição das 1 itologias

A. Meta-hornblenditos

São rochas macroscopicamente muito homogēneas, com estrutura predominantemente xistosa, cor verde escura e de grã mëia. Encontram-se freqüentemente intemperizadas, neste caso com cores verde-clara a verde-amarelada.

\section{A.1. Meta-hornblenditos propriamente ditos}

São constituídos quase totalmente por hornblenda. Como acessōrios ocorrem plagiocläsio, quartzo e opacos. As rochas exibem textura nematoblästica, por justaposição (Microfoto 
8). A hornblenda constitui cristais predominantemente subedrais, e se caracteriza por sua pobreza em inclusões, quase sempre de opacos. Predomina amplamente a hornblenda com forte pleocroismo, sendo X-verde amarelado, Y-verde castanho e Z-verde escuro, e subordinadamente a variedade fracamente pleocróica (Actinolita) com X-verde pālido a incolor, Y-verde amarelado e Z-verde claro.



Microfoto 8 - Meta-hornblendito. Textura nematoblástica por justaposição. Nicois//, aumento 10x.

As duas variedades de hornblenda coexistem em aparente equilíbrio, não se observando reações entre elas. Em algu mas amostras foram observados delgados leitos da variedade clara com cristais ripiformes entre a hornblenda escura.

0 quartzo e o plagioclāsio constituem cristais pequenos, xenormóficos, situados nos interstīcios dos cristais de hornblenda. 0 quartzo não exibe extinção ondulante e o plagioclá sio é do tipo andesina ăcida e raramente com geminação polissintëtica. Os grãos de opacos são diminutos e anedrais. Em apenas uma amostra foram verificadas raras e diminutas lamelas de biotita com contatos difusos em relação à hornblenda. 
Estes são extremamente raros, e foram observados a] gumas lentes nas proximidades da mina de calcārio localizada a W da Fazenda Cristālia. São constituj̃dos predominantemente por hornblenda fortemente pleocrōica, com no mäximo $5 \%$ de diopsĩdio.

A hornblenda constitui cristais quase sempre sube drais, com o eixo c fortemente iso-orientado, e tamanho mëdio de $0,4-0,5 \mathrm{~mm}$ ao longo de $c$, originando textura nematoblästica.

0 diopsĩdio apresenta-se sob a forma de cristais ir regulares, com atē $1,0 \mathrm{~mm}$ na sua maior extensão, e rico em inclu sões de hornblenda e opacos. Ocorrem tambëm raros cristais irregu lares de quartzo e plagiocläsio, ambos intersticiais.

\section{B. Meta-ultramafitos}

Devido à composição mineralögica destas rochas, que são facilmente alteradas pelos agentes intempēricos, praticamente faltam afloramentos frescos. Este fato dificulta tanto a delimita ção precisa dos corpos, bem como o estudo destas rochas.

\section{B.1. Meta-piroxenitos}

São rochas de granulação mëdia, homogêneas compactas, escuras e, pelo intemperismo, exibem cor ocre característica. Aparentemente estão restritas a um corpo de forma lenticular, situado na ärea delimitada a SW da Fazenda Cristälia. Apresentam composição simples, predominantemente clinopiroxēnio (90\% da amostra), hornblenda e raros cristais de opacos e serpentina.

0 piroxënio e levemente rosado, sem pleocroismo, ocorrendo sob a forma de cristais euedrais a subedrais que atingem até $1,0 \mathrm{~mm}$ ao longo de c. 0 contato entre os cristais ē quase sem pre irregular, sendo rara a interpenetração. Em raros casos a cli vagem (100)acha-se fracamente desenvolvida.

A hornblenda $\vec{e}$ da variedade castanha, pouco pleocröica, constituindo cristais quase sempre anedrais e subedrais, com dimensöes mäximas de $0,4 \mathrm{~mm}$ ao longo de $c$. Aparentemente a hornblenda formou-se às custas do piroxênio. E comum a ocorrēncia de intercrescimento paralelo e a presença de cristais irregulares 
de anfibolio no piroxênio, com contatos difusos.

os opacos, em grãos irregulares, e a serpentina, em pequenas e alongadas fibras, são bastante raras.

\section{B.2. Meta-peridotitos}

Os meta-peridotitos são de granulação mëdia a gros sa, preto-esverdeados geralmente intemperizados, e que pelo meta morfismo, sofreram uma transformação quase que total da mineralo gia primäria. Estas rochas estão restritas à concentração situada a W-SW da Fazenda Cristália, constituĩndo delgadas lentes ou pequenos corpos arredondados com diāmetros de no mäximo alguns metros. Sua importância na ärea reside na ocorrência de tremolita que estä sendo explorada. Rochas similares foram registradas por Wernick (1967) na região de Amparo, a S-SW da ārea ora inves tigada.

Da rocha original são muito mal observados raros cristais de olivina e de piroxênios. A olivina exibe cor neutra, ocorrendo sob a forma de nūcleos irregulares, que atingem 0,2 $0,3 \mathrm{~mm}$. Esta encontra-se sempre envolvida pelos piroxēnios. Os piroxênios são predominantemente clinopiroxênios e constituem pe quenos cristais subedrais.

A fração metamörfica ē amplamente dominante, sendo composta por tramolita que constitui cristais com atē $2,0 \mathrm{~mm}$ na sua maior extensão, imersos numa matriz de talco cujas fibras atingem localmente mais de $1,0 \mathrm{~mm}$. São comuns nōdulos que : apenas raramente ultrapassam $0,7 \mathrm{~mm}$ de serpentina distribuỉdos homogeneamente por toda a rocha. São freqüentes finos grānulos de opacos dispersos e associados ao talco.

Uma das amostras examinada ē composta essencialmen te por clorita, contendo ainda cerca de $5 \%$ de vermiculita e raros cristais de opacos e epidoto. Apresenta estrutura xistosa e textura lepidoblästica. A clorita forma lamelas orientadas com atë 2,0 mm na maior dimensão. A vermiculita de distribuição caótica não mostra orientação e constitü lamelas que atingem atē $3,0 \mathrm{~mm}$ de tamanho. Opacos e epĩdoto representam minūsculos grãos irregulares associados à clorita.

A classificação da rocha original como peridotito, 
baseou-se na observação dos restitos acima descritos, ainda pré. servados, no material resultante da transformação, bem como no fato de terem sido descritas rochas semelhantes por Wernick.(1967) na região de Amparo, contígua ā ärea atualmente em foco.

\section{Meta-argititos, -conglomerados, -arenitos e -arcösios} Generalidades

Como mencionado em capituio precedente, trata- se de uma sequência metassedimentar anquimetamōrfica, bastante decomposta e pertencente à Formação Eleutērio. Corresponde a uma estreita fajxa que atinge, na ārea investigada, uma extensão de $5 \times 1 \mathrm{~km}$, com orientação geral NE-SW; situada cerca de $2 \mathrm{~km}$ a oeste do vilarejo de Eleutērio, na parte norte da ārea. Seus $1 \mathbf{i -}$ mites são eminentemente tectōnicos, estando a parte ocidental em contato com as rochas cataclasadas e milonitizadas da $\cdot$ : falha transcorrente de Jacutinga; a borda oriental, com os muscovita quartzitos e biotita hornblenda gnaisses da associação litológica (C). Na extremidade sul, de difícil observação, o contato é tambëm abrupto e faz-se com os gnaisses graniticos. Embora este jam em contato com as rochas milonitizadas da falha de transcorrência de Jacutinga, os metassedimentos da Formação. Eleutério não foram afetados pela milonitização.

As rochas desta Formação mostram a mesma posição espacial que os metassedimentos adjacentes, embora a intensidade do metamorfismo e as litologias sejam muito diferentes. 0 aca mamento exibe direção geral NE, variando o mergulho entre 450 e 90 p para SW.

\section{Descrição dos tipos litolögicos}

Essa sequēncia metassedimentar ê composta $\quad$ essen cialmente por meta-arenitos e meta-arcōsios de vārios tipos, ten do associados meta-argilitos, meta-conglomerados e meta-brechas. Destacam-se as seguintes considerações a respeito dos tipos lito. Tögicos: 
amplamente predominantes. São rochas de granulação mēdia, selecionadas e de cor branca-acinzentada. A estrutura $\vec{e}$ frequentemente maciça, porēm, não faltam estratificações plano paralelas e localmente cruzadas. São compostos essencialmente.. por gräos arredondados a subarredondados de quartzo e fragmentos angulosos de feldspatos. Exibem räpidas variações locais tanto na granulometria, adquirindo às vezes aspecto conglomerātico, quanto na proporção quartzo-feldspato. Estas rochas encontram-se muj to descompostas produzindo um material quartzo-caolinitico branco.

Os meta-argizitos ocorrem associados às litologias anteriores sob 3 formas:

a) Como camadas espessas que podem atingir ate mais de 50 metros de espessura estando praticamente isentas de intercalações de outros metassedimentos. Normalmente estas camadas são precedidas lateralmente por outras de mesma natureza e de espessuras reduzidas. Seus contatos com os meta-arcösios são abruptos. Localmente são um pouco siltosas, com cores predominan temente castanho-avermelhadas com faixas amareladas. Exibem pronunciada clivagem ardosiana levemente discordante do acamamento. Uma das melhores exposições situa-se no contato oriental do corpo, onde é cortado por uma estrada de terra que sai de Eleutério em direção ã Fazenda do Salto. Este afloramento mostra um cerrado sistema de fraturamento, evidenciando o efeito de esforços tectônicos.

b) Como delgados leitos, camadas e lentes no metaarcösio, com o qual exibem contatos abruptos. 0correm constituin do quase sempre concentrações que resultam em uma alternāncia en tre meta-arcósios e meta-argititos. Localmente os leitos dos meta-argilitos acham-se deformados e brechados. São rochas maciças e às vezes com discreta clivagem ardosiana. A cor pode ser tanto cinza quanto castanha-avermelhada.

c) Como seixos subarredondados a angulosos, sendo camuns os alongados, com dimensões variáveis, atingindo no māximo $10 \mathrm{~cm}$ ao longo de sua maior dimensão. Ocorrem concentrados nos meta-arcōsios principalmente nas vizinhanças das camadas, leitos ou lentes dos meta-argilitos anteriormente mencionados. Sua densidade $\vec{e}$ baixa, com distribuiçăo heterogênea na matriz, mostran- 
do orientação aproximadamente paralela ao acamamento. Em alguns locais apresentam-se levemente achatados. A matriz, que é consti tuĩda pelos meta-arcōsios, apresenta granulação tanto mais grosseira quanto major a concentração destes seixos.

Os meta-conglomerados e meta-brechas mostram uma certa relação entre as dimensões dos seixos ou fragmentos com a posição geogräfica que ocupam dentro do corpo. Assim, podem ser distinguidos os seguintes tipos de rochas conglomeräticas:

a) Constituido por fragmentos angulosos a subangulosos, atē mëtricos, de muscovita quartzitos e gnaisses, cimenta dos por matriz tanto arenosa quanto argilosa. Estas rochas estão situadas na metade inferior do corpo, constituindo uma faixa irregular pröximo ao seu contato oriental. A constituição dos frag mentos de muscovita quartzitos e gnajsses é idēntica a das rochas inediatamente a leste do corpo.

b) Representados por pequenos seixos subangulosos de muscovita quartzitos e gnaisses, que atingem no máximo 4 a 5 cm e se mostram discretamente orientados em matriz predominantemente arenosa. Constituem tanto leitos contīnuos de espessuras a të decimétricas, quanto lentes e bolsões pouco expressivos. Embo ra tenham sido observados em praticamente todo o corpo, a inten sidade destas ocorréncias diminui de leste para oeste.

c) Formado por concentrações locais de fragmentos subangulosos a angulosos de meta-argilitos no meta-arcōsio,prōximos das camadas e lentes dos meta-argilitos anteriormente descritos. Seixos de muscovita quartzitos e de gnaisses podem ocorrer associados.

\section{Considerações Finais}

As rochas de granulação mais grosseira desta Forma ção ocorrem na parte oriental do corpo. Assim, hā uma diminuição geral da granulometria destas rochas e o consequente incremento de meta-argilitos para a borda ocidental. os meta-conglomerados e meta-brechas, que são freqlentes na borda oriental, tornam- se raros na parte ocidental e säo compostos por seixos de dimensões reduzidas. Essa variação na granulometria dos metassedimentos po de indicar que a fonte do material original provavelmente estava 
a leste do corpo e o movimento se deu para oeste. Por outro lado, a posição elevada das camadas que mergulham para NW, sugere uma deposição em regime de maior energia para a base com dimir. nuição progressiva em direção ao topo.

A hipōtese proposta por Wernick e Penalva (1974b) de que a Formação Eleutërio trata-se de um depōsito molassōide, gerado por regime torrencial a partir das rochas metamörficas situadas imediatamente a leste, encontra apoio nas nossas verificações de campo. Os meta-argilitos indicam que localmente o regime evoluiu para planícies de inundação.

Merece destaque o fato desses metassedimentos apresentarem seixos e fragmentos de muscovita quartzitos e de gnaisses do Bloco Jundiai, estando ausentes seixos dos migmatitos e granitöides pertencentes ao Grupo Pinhal, situado imediatamente a oeste do corpo metassedimentar.

Dados geocronolögicos para calco-xistos (meta-mar gas) da Formação Pouso Alegre, situada nas proximidades da cidá de homônima e equivalentes à Formação Eleutērio, revelaram idá des compativeis com a fase final do Ciclo Brasiliano (Hama e Cunha, 1977).

Embora sejam necessārios estudos mais detalhados, as evidencias acima citadas, podem indicar que:

a) Durante a fase final do Ciclo Brasiliano,estes sedimentos molassóides, depositados em bacias tectónicas, foram fracamente metamorfizados, Wernick (1978a).

b) Estes metassedimentos teriam sido preservados por fortes subsidencias do tipo "graben", resultantes de värias fases de soerguimentos mais ou menos intensas, desta faixa da borda da Bacia do Paranā, pela reativação de velhas linhas estruturais que teriam ocorrido durante todo, o Fanerozóico.

Estes movimentos teriam sido a causa da inclinação das camadas de metassedimentos e do seu contato com as rochas do Grupo Pinhal.

\section{Milonitos e Cataclasitos}


Nestes grupos estão incluĩdas rochas que sofreram deformação pōs-cristalina por ação de metamorfismo dominantemen te dinâmico. O termo milonito refere-se a uma rocha de granuiação fina, laminada, formada por extrema microbrechação e moagem de rochas durante o movimento em superficies de falhas, com pequeno ou nenhum crescimento de novos minerais (Apud American Geo logical Institute, 1973, acepção de Lapworth, 1885). Quando houve recristalização a rocha passa a denominar-se filonito. o cata clasito é uma rocha que se forma por fragmentação num processo menos intenso que no caso do milonito, sendo ainda reconhecivel a natureza da rocha primitiva (Williams et al., 1970, p.219).

os milonitos e cataclasitos são bastante frequentes ao longo de inümeras falhas que retalham praticamente toda a ārea estudada, com espessuras muito variāveis, raramente ating in do uma ou duas dezenas de metros. Contudo, no canto superior NW da ärea encontra-se uma faixa que atinge cerca de $3 \mathrm{~km}$ de espessura, constituindo pequena parte da zona de Transcorrência de Jacutinga. Segundo Ebert (1968, p. 222), a zona de falhamento de Jacutinga se estende comprovadamente de Itapira (SP) atē Ipuiuna (MG) e provavelmente atē São Gonçalo (MG), Figura 4. Merece destaque, tambëm, uma faixa ao norte da Usina Nossa Senhora Apareci da com aproximadamente 80 metros de espessura e com orientação geral NNE-SSW.

Essas rochas são os produtos de deformações cataclästicas, em maior ou menor grau, de todas as litologias previa mente descritas, com exceção dos metassedimentos da Formação. Eleutērio. Na zona de transcorrência de Jacutinga os efeitos cataclásticos se manifestam principalmente em rochas graniticas do Grupo Pinhal. Esses granitóides que ocorrem a norte da zona de falhamento, fora da ärea mapeada, são acinzentados, constituĩdos essencialmente por quartzo, plagioclāsio, microclïnio e biotita. São frequentemente porfiroblāsticos, com cristais prismäticos ou ocelares de microclinio róseo orientados nas rochas, atingindo a té $6 \mathrm{~cm}$ na sua maior dimensão. Para descrições mais detathadas destas rochas ver capitulo referente à geologia regional e, sobretudo, Wernick (1977, 1978 a,b) e Wernick e Penalva (1980). 
Os milonitos que normalmente ocupam a parte central das faixas cataclasadas, gradacionam para cataclasitos e destas para outras rochas que não mostram efejtos de tectonismo. Nas fai xas mais espessas, e invariavelmente ao longo da zona de falhamen to a NW da ārea, as rochas afetadas se dispõem em faixas alternadas mostrando cisalhamento em graus variāveis. Nas faixas onde os esforços cisalhantes foram intensos, são encontrados milonitos e filonitos que se alternam com faixas onde a cataclase foi menos intensa. Essas faixas apresentam espessuras variāveis, podendo ser de escala milimētrica atë mais de uma dezena de metros.

Uma das feições cataclásticas que permite fäcil verificação na zona do falhamento de Jacutinga, ē a presença muito constante, ao longo das descontinuidades, de cataclasitos com cristais remanescentes. Trata-se de uma rocha onde o fraturamento do material foi muito intenso, ocasionando a formação de matriz muito fina. Destacam-se, nessa massa, cristais maiores, sen do muito freqlentes os de feldspato róseo, que possibilitam identificar o caräter granitico da rocha original.

Com relação à natureza petrogrä́fica da rocha primitiva pode-se notar diferenças acentuadas dos efeitos catacjāst cos. Em função da textura, estrutura e composição mineralógica,as rochas que melhor registram os esforços do metamorfismo são os quartzitos, gnaisses, migmatitos e granitos, devido à sua granula ção grosseira primitiva e tambēm à sua constituição quartzosa e quartzo-feldspätica que favorece o fraturamento. Quando as rochas. afetadas apresentam caracteristicas plästicas, como o caso de mui tos afloramentos de biotita xisto, os efeitos da movimentação direcional são dificeis de serem percebidos.

0 desenvolvimento de bandas de minerais muito finos se constitui no efeito cataclästico mais marcante em rochas cristalinas. Nos cataclasitos, as bandas são espaçadas e pouco orientadas, envolvendo fragmentos angulosos a lenticulares de rochas pouco afetadas. Nos milonitos, as bandas são menos espaçadas, che gando a coalescerem. A diminuição gradativa dos fragmentos de rochas, desenvolve bandas melhor orientadas. Os milonitos porfiro clāsticos se caracterizam por apresentar fragmentos remanescentes de cristais de feldspatos, e subordinadamente de quartzo, arredon dados a subarredondados, envolvidos por uma matriz rochosa : com bandeamento encurvados nas proximidades dos porfiroclastos. 
Nos Jocais em que a "moagem" das rochas afetadas.pę los esforços foi muito intensa, aparecem milonitos evoluídos, nos quais a foliação é proeminente, imprimindo um aspecto de filito ao menor sinal de intemperismo. Este fenōmeno pode ser visto na falha de Jacutinga, na estrada de terra, cerca de 500 metros, a oeste da Fazenda do Salto, e mesmo em outras falhas de menon expressão, como no caso da falha com disposição NW-SE, ào sul da Fazenda do Matão, e no alinhamento que tangencia o Rio Eleutërio.

Nos casos extremos de moagem, produzem-se rochas ultramiloniticas, de granulação extremamente fina e densa, macros copicamente de aspecto maciço, assemelhando-se muito a felsitos. Estas rochas são brancas a amareladas ou cinzentas, podendo-se no tar, entre muitas, bonitas exposições na parte central da faixa situada entre a Usina Nossa Senhora Aparecida e o Rio do Peixe, bem como no leito do cörrego da Boa Vista, a NE da Fazenda do Sa to. Nestas ocorrências, o ultramilonito chega a atingir espessuras de quase uma dezena de metros.

Descrição microscōpica

Estas rochas exibem uma variação na textura de acor do com a intensidade de deformação. Surgem, assim, primeiramente os cataclasitos com textura "mortar", constituijdos por uma fina massa cataciāstica, predominantemente quartzosa, que cimenta cris tais de feldspatos parcialmente fraturados e deformados. : Estes cristais de feldspatos exibem fraturas nas bordas, envolvendo os fragmentos do nücleo que resistiram a deformação, (Microfoto 9).

No segundo tipo, tem-se cataclasitos com textura "flaser". A orientação das bandas $\bar{e}$ mais saliente, separando agre gados minerais ou cristais de feldspatos que exibem formas fusiformes ou ovaladas, resultantes de forte movimento diferencial.

Muitos milonitos possuem uma textura laminada, na qual as läminas individuais se assinalam por diferenças no :tamanho dos grānulos e na cor. Na textura ultramilonitica, tanto o quartzo quanto o feldspato acham-se totalmente esmagados, o mesmo ocorrendo com a biotita, associada ao epidoto.

A composição destas rochas estä na dependēncia da rocha primäria, sendo mais comuns as constituidas basicamente por quartzo, e as quartzo-feldspäticas combiotita, epidoto e rara 


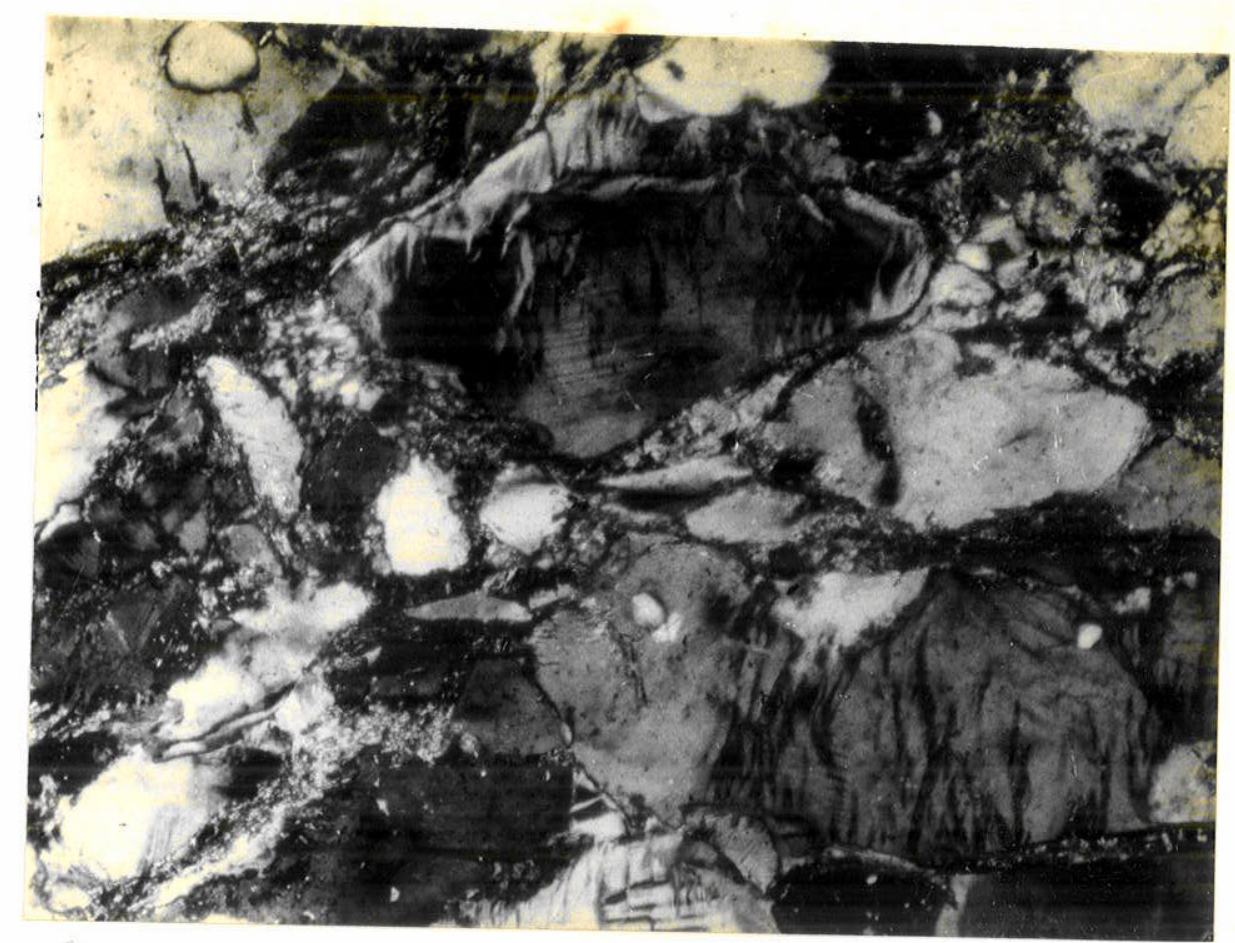

Microfoto 9 - Cataclasito com textura "mortar". Nicois X, aumento $25 x$.

hornblenda. Os acessōrios são: granada, apatita,zircão e opacos.

0 quartzo exibe-se fraturado, esmagado, parcialmen te recristalizado e constitui, quase sempre, a maior parte da fina massa cataclāstica. Nos cristais maiores são comuns: extinção ondulante, fraturas, zonas de esmagamento e textura em pacote.

0 plagiocläsio, mais resistente à deformação, exibe cristais angulosos, fraturados, fusiformes ou ovalados. Os planos de geminação albita encontram-se comumente deformados e encurvados, freqüentemente com extinção ondulante. Devido à intensa moagem a que foram submetidas as rochas, facilitando assim os processos de alteração, os cristais de plagioclāsio apresentam pronunciada sericitização e epidotização.

0 microclinio exibe feições semelhantes às do plagioclāsio. Na falha de Jacutinga, ele predomina sobre o plagiocläsio, constituindo a maior parte dos porfiroclastos. E quase sempre micropertỉtico, com frequentes inclusões de plagioclásio sericitizado.

A biotita parcialmente ou totalmente cloritizada, 
constitui fiapos irregulares muitas vezes finamente esfarelados, com planos de clivagem deformados que se amoldam nos planos de ci zalhamento. A hornbzenda torna-se quebradica, irregular e normalmente alterada para epidoto.

0 epidoto, formado principalmente às custas do plagiocläsio e da hornblenda, ocorre sob a forma de pequenos: cris tais subedrais isolados, ou constituindo faixas epidotizadas nos planos de fraturamento, sendo este caso muito comum em lâminas delgadas de milonitos e cataclasitos.

Entre os acessóxios, ocorrem grānulos fragmentados de granada e titanita envolvidos pela matriz de granulação fina. Aparecem ainda apatita e zircão, com formas subedrais, e opacos
disseminados na matriz.

\section{Considerações finais}

0 exame das rochas cataclasadas, principalmente da faixa transcorrente de Jacutinga, permitiu observar uma sērie de variações texturais e estruturais, a medida que as rochas foram submetidas a esforços cisalhantes cada vez mais pronunciados. Re-
sumimos a seguir:

1. Os primeiros efeitos de fragmentação se refletem no micro-fraturamento do quartzo, enquanto os feldspatos não exibem fraturamento ou o fazem de modo discreto. Os cristais de feldspato mais fragmentados apresentam sericitização e epidotizaçăo. Ao microscöpio, ainda não ser observa ban deamentos e è pouco frequente a recristalização de quartzo.

2. Num estägio mais avançado de cataclase, a presen ça de bandeamento e muito frequente e a recrista lização de quartzo ē mais pronunciada. Os cataclasitos exibem inicialmente textura mortar, seguida pela textura flaser indicadora de maior intensidade dos fenōmenos cataclästicos.

3. Em algumas bandas dos milonitos, a recristalização do quartzo é total. As bandas de agregados minerais imprimem à rocha uma textura orientada. 
Os milonitos porfirociásticos apresentam fragmentos angulosos re manescentes, principalmente de microclinnio. Nas faixas onde apa recem milonitos evoluidos, associam-se os ultramilonitos.

\section{V.3.1. Estudo quĩmico de muscovitas}

0 uso da muscovita como mineral indicador petrogenético vem sendo, recentemente, objeto de detalhadas investigações. Isto, deve-se ao fato deste mineral admitir a substituição de numerosos ions em sua estrutura, constituindo diversas solu ções sōidas altamente complexas. Dentre as principais substitui ções ionnicas destacam-se:

- A substituição do $\mathrm{K}^{+}$interlamelar pelo $\mathrm{Na}^{+}$originando uma solução sōlida com os membros extremos representados pela muscovita e paragonita. As relações entre estes dois membros finais encontram-se bem detalhadas nos trabalhos de Eugster e Yoder (1955) e Eugster et al. (1972).

- A substituição do $\mathrm{Al}^{3+}$ octaedral pelos ions $\mathrm{Fe}^{2+}$ e $\mathrm{Mg}^{2+}$, e a do $\mathrm{Al}^{3+}$, contido nas camadas tetragonais, pelo $\mathrm{Si}^{4+}$, desenvolvendo-se outra solução sōlida entre a muscovita e o hipo tético membro final celadonita, apresentando como termo intermediārio a fengita.

- Ainda pela substituição do $A 1^{3+}$ octaedral pelo $\mathrm{Fe}^{3+}$, constituem-se duas outras soluções sólidas representadas pelos membros finais muscovita e ferromuscovita, e pela fengita e ferro-fengita.

Diversos autores tem demonstrado particular interesse no estudo da variação da composição na muscovita em função do grau metamōrfico e da composição quïmica da rocha total.0 maior nümero de dados provēm de estudos sobre espécies dos Alpes Italianos e Suifcos devidos principalmente a Graeser e Niggli (1967), Wenk (1970), Sassi (1972) e Cipriani et al. (1971), e sobre a ärea de Maine, nos Estados Unidos da América do Norțe, por Guidotti (1973, 1978a, 1978b). O trabalho de Cipriani et al. reunindo todas as referēncias mais importantes atē aquela ëpoca, mostra, de maneira bastante compreensiva, a influência das cond $\underline{i}$ ções ambientais sobre a composição da muscovita durante a recris talização metamörfica. Estes mesmos autores, apōs desenvolverem 
diversos diagramas para mostrar relativamente o efeito das poss $\mathbf{j}$ veis variāveis durante o metamorfismo, defendem que a composição da muscovita $\bar{e}$ controlada predominantemente pelas condições de temperatura e pressão, enquanto que a influência de outros fato res (composição quîmica da rocha e/ou assemblēia mineralōgica,fá ses fluĩdas, etc.), embora não insignificante, são de importāncia secundāria.

Trabalhos posteriores, principalmente de Guidotti e Sassi (1976), Guidotti (1973, 1978b), indicam que a extensão das värias soluções sölidas, apresentadas pela muscovita, dependem. Targamente dos parâmetros temperatura e pressão, tornando- a um mineral de grande utilidade para se obter informações qualita tivas e semi-quantitativas destes parāmetros em āreas metamōrficas. Entretanto, a composição quīmica da rocha e/ou assemblēia mineralögica, exerce um efeito significativo sobre estas soluções sölidas. Contrapondo Ciprianj et al. (op.cit.), os autores supra citados, sustentam que o uso da muscovita, como indicador petrogenētico, sö pode apresentar resultados satisfatörios atravēs de um rigoroso controle dessas variāveis.

Numerosos trabalios tem contribuido grandemente pa ra se conhecer o comportamento das soluções sōlidas, envolvendo a muscovita, em função das condições metamörficas, destacando-se os de Eugster e Yoder (1955), Velde (1965, 1967, 1972), Seki (1973), Guidotti (1966, 1969, 1974), Thompson (1974), e muitos ou
tros.

Nosso estudo apresenta uma tentativa de verificar possiveis variações nas condições fisicas do metamorfismo (tempe ratura e pressão), na região de Itapira, atravēs da anālise da composição quĩmica da muscovita.

As anälises foram efetuadas em doze amostras de quartzitos contendo percentagens variadas de muscovita. Foram utilizados os quartzitos, por serem a ünica litologia que contēm suficiente quantidade de muscovita em sua assemblëia mineralógica.

A amostragem, que tambëm depende da ocorrēncia dos quartzitos, foi feita de forma a englobar toda a extensão da ärea mapeada, nos sentidos $N-S$ e E-W, (ver mapa de localização dos afloramentos em anexo). 
A assemblēia mineralōgica, com exceção dos minerais opacos que estão ausentes na amostra 301, localizada a W da ärea, permanece praticamente a mesma em todas as amostras, apresentando Quartzo + 0ligocläsio + Feldspato potässico + Muscovita + (Opacos). No entanto, a percentagem destes minerais varia cons $\mathbf{j}$ deravelmente: a oeste, ocorrem quartzitos feldspäticos ricos em muscovita, tornando-se gradativamente mais puros para leste, onde, de forma mais ou menos repentina, se mostram extremamente empobre cidos nestes minerais. Os minerais opacos, embora acessōrios, apresentam a mesma tendēncia.

\section{V.3.1.1. Resultados e discussão}

As anälises quimicas das muscovitas foram realizadas, como jämencionado no capituio I, utilizando-se a tēcnica da microssonda eletrónica, sendo os dados obtidos apresentados na Ta bela 1. Por problemas tēcnicos, todo o Fe da muscovita foi determinado como sendo $\mathrm{Fe}^{2+}$. Esses valores representam a mēdia resultando da anālise de cem pontos em cada amostra. Deve-se ressaltar que, durante as anālises, foram excluỉdas as muscovitas que apresentavam orientação divergente à da foliação principal da rocha, por suspeitar-se da existência de majs de uma fase de recristalização destes minerais. Os dados referentes à förmula quïmica, expressa na base de 22 ätomos de oxigēnio, acham-se resumidos na Ta bela 2 .

Para estabelecer-se um controle da composição da muscovita em. função da composição quïmica da rocha total, foi ela borado o diagrama da Figura 5 , correlacionando a $\%\left(M g 0+\right.$ FeO $\left._{\text {tot. }}\right)$ das micas (Tabela T) e a \% (MgO + Fe0 tot.) da rocha total (Tabela 3). Nota-se, primeiramente, que hä uma relação direta no conteūdo desses ōxidos na composição da muscovita em função do seu teor na rocha total. Apenas o ponto 346 apresenta-se um tanto anōmalo, refletindo, provavelmente, uma recristalização em desiquilïbrio. Ainda, apesar da baixa densidade de pontos, parece clara a presença de uma unica linha regressiva no diagrama, indicando que as ro chas se formaram sob as mesmas caracteristicas metamörficas regio nais, o que possibilita a correlação entre as mesmas.

A fim de proporcionar uma melhor caracterização das anälises das muscovitas, elaboramos, com base em Cipriani et al. 
TABELA

COMPOSICAO QUTMICA PARCIAL DE MUSCOVITAS DOS MUSCOVITA QUARTZITOS DA REGIAO DE ITAPIRA-SP.

$\begin{array}{lrrrrrrrrrrrr} & 1 & 14 & 28 & 44 & 100 & 150 & 135 & 248 & 275 & 301 & 346 & 356 \\ \mathrm{SlO}_{2} & 45,64 & 46,56 & 45,67 & 45,69 & 47,40 & 44,68 & 45,99 & 46,63 & 45,19 & 46,76 & 45,74 & 45,59 \\ \mathrm{FeO}^{*} & 4,63 & 4,55 & 4,67 & 4,92 & 1,12 & 5,06 & 1,49 & 5,63 & 4,66 & 1,28 & 5,77 & 5,52 \\ \mathrm{MgO} & 1,10 & 0,94 & 0,90 & 1,01 & 1,00 & 0,79 & 1,15 & 1,93 & 1,23 & 0,97 & 0,79 & 2,25 \\ \mathrm{Al}_{2} \mathrm{O} 3 & 32,21 & 32,84 & 33,56 & 33,00 & 36,21 & 32,20 & 32,99 & 28,56 & 30,94 & 33,69 & 30,05 & 29,66 \\ \mathrm{~K}_{2} \mathrm{O} & 12,14 & 11,2,8 & 11,64 & 11,14 & 10,44 & 10,79 & 10,89 & 10,84 & 10,86 & 10,59 & 10,70 & 10,64 \\ \mathrm{Na}_{2} \mathrm{O} & 0,71 & 0,51 & 0,55 & 0,62 & 0,86 & 0,48 & 0,49 & 0,43 & 0,53 & 0,74 & 0,51 & 0,39 \\ \mathrm{Total} & 96,43 & 96,68 & 96,99 & 96,38 & 97,03 & 94,00 & 93,00 & 94,02 & 93,41 & 94,03 & 93,56 & 93,05 \\ \mathrm{EMgOHFO} & 5,73 & 5,49 & 5,57 & 5,93 & 2,12 & 5,85 & 2,64 & 7,56 & 5,89 & 2,25 & 6,56 & 7,77\end{array}$

TABELA 2

FORMULA ESTRUTURAL, EXPRESSA NA BASE DE 22 ATOMOS DE OXIGENIO.DAS MUSCOVITAS DOS MUSCOVITA QUARTZITOS DA REGIAO DE ITAPIRA-SP

$\begin{array}{lcccccccccccc} & 1 & 14 & 28 & 44 & 100 & 150 & 135 & 248 & 275 & 301 & 346 & 356 \\ \mathrm{Si} & 6,191 & 6,243 & 6,130 & 6,165 & 6,181 & 6,181 & 6,301 & 6,463 & 6,284 & 6,308 & 6,377 & 6,317 \\ \mathrm{AI}^{\mathrm{IV}} & 1,809 & 1,757 & 1,870 & 1,835 & 1,819 & 1,819 & 1,699 & 1,537 & 1,716 & 1,692 & 1,623 & 1,683 \\ \mathrm{AI} & 3,342 & 3,433 & 3,440 & 3,413 & 3,745 & 3,431 & 3,625 & 3,134 & 3,353 & 3,665 & 3,317 & 3,162 \\ \mathrm{Fe} & 0,525 & 0,510 & 0,525 & 0,555 & 0,122 & 0,586 & 0,171 & 0,653 & 0,542 & 0,144 & 0,651 & 0,641 \\ \mathrm{Mg} & 0,223 & 0,188 & 0,181 & 0,204 & 0,194 & 0,162 & 0,232 & 0,398 & 0,256 & 0,195 & 0,164 & 0,466 \\ \mathrm{~K} & 2,100 & 1,929 & 1,994 & 1,918 & 1,736 & 1,904 & 1,891 & 1,915 & 1,922 & 1,824 & 1,903 & 1,877 \\ \mathrm{Ka} & 0,188 & 0,134 & 0,144 & 0,161 & 0,217 & 0,128 & 0,129 & 0,115 & 0,140 & 0,194 & 0,137 & 0,105\end{array}$

TABELA 3

DETERMINACAO DOS TEORES DE FEO O MgO DOS MUSCOVITA QUARTZITOS DA REGIAO DE ITAPIRA-SP

\begin{tabular}{|c|c|c|c|c|c|c|c|c|c|c|c|c|}
\hline & 1 & 14 & 28 & 44 & 100 & 150 & 135 & 248 & 275 & 301 & 346 & 356 \\
\hline $\mathrm{FeO}^{*}$ & 0,643 & 0,463 & 0.630 & 0,399 & 0,064 & 0,540 & 0.052 & 0.720 & 0,610 & 0,050 & 0,309 & 0,913 \\
\hline $\mathrm{MgO}$ & 0,149 & 0,083 & 0.149 & 0.099 & 0,033 & 0,149 & 0,083 & 0,282 & 0,182 & 0.017 & 0,050 & 0,265 \\
\hline $\mathrm{FeO}+\mathrm{MgO}$ & 0.792 & 0,546 & 0,779 & 0,498 & 0,097 & 0,689 & 0,135 & 1,002 & 0,792 & 0.067 & 0,359 & 1.178 \\
\hline
\end{tabular}

* Fe calculado como feo 


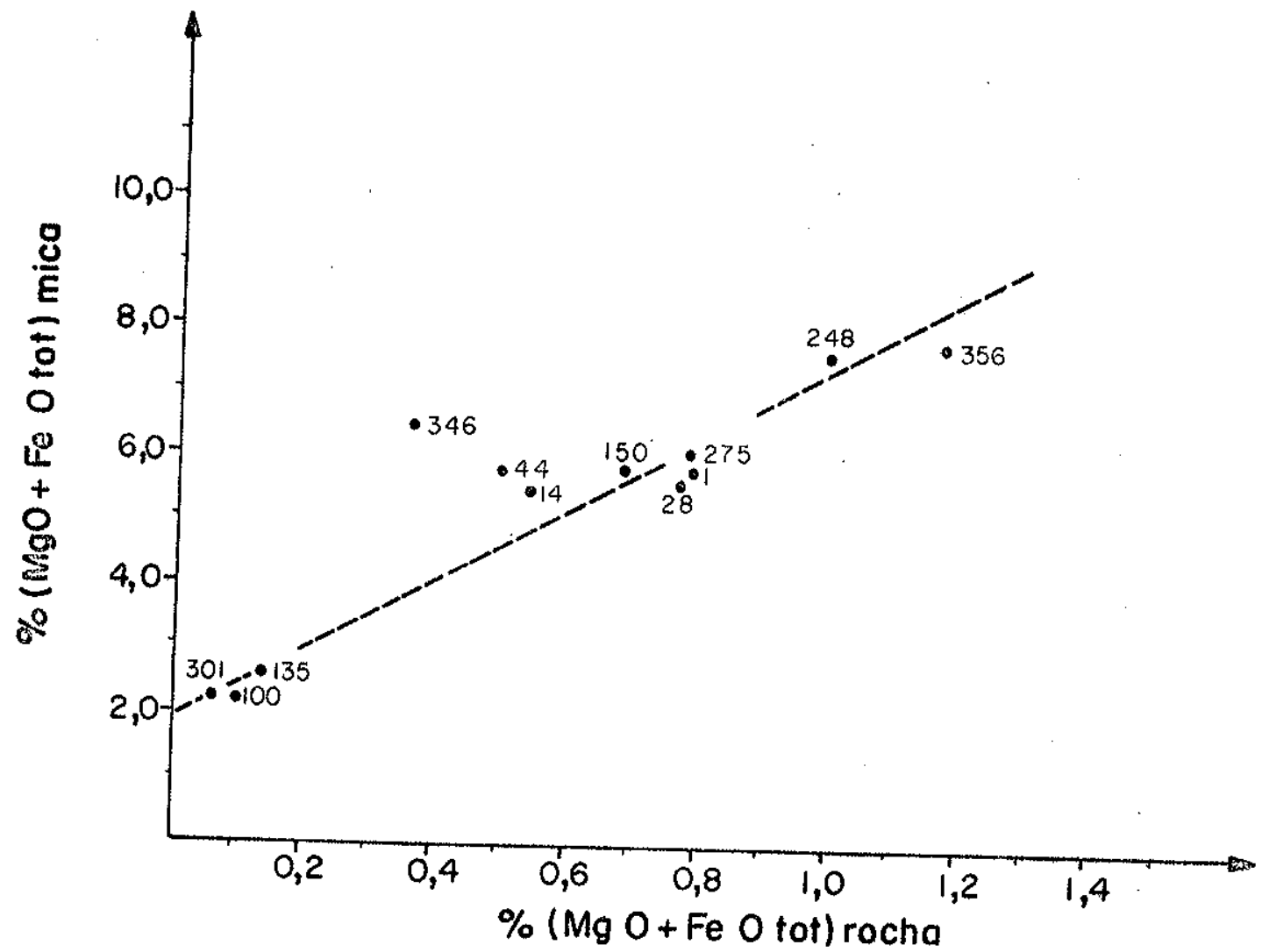

Figura 5 - Relação entre a $\%\left(\right.$ MgO $\left.+\mathrm{FeO}_{\text {tot }}\right)$ da muscovita e a $\%$ $\left(\mathrm{MgO}+\mathrm{FeO}_{\text {tot }}\right)$ da rocha total para os muscovita quart zitos da região de Itapira - SP.

(1971), os diagramas das Figuras 6,7 e 8 , resultantes da projeção dos dados contidos na Tabela 2.

A Figura 6, relacionando o conteūdo de Fe e Mg das muscovitas em função da temperatura, apresenta, em termos gerais, uma correlação positiva entre os dois cations, ao mesmo tempo que evidência uma tendência negativa entre a temperatura e us conteūdos tanto da abscissa quanto da ordenada. Esta tendēncia negativa indica uma redução no conteūdo fengita, que deve representar um incremento da temperatura metamörfica, ocasionando a substituição dos cātions $\mathrm{Fe}^{2+}$ e $\mathrm{Mg}^{2+}$ das camadas octaedrais pelo Al, conduzindo a mica para a composição teōrica da muscovita.

$\mathrm{Na}$ Figura 7 , onde os cátions interlamelares tambēm são considerados, o diagrama tem por finalidade uma melhor carac terização da solução sōlida mais pobre no conteūdo fengita. Segun do Cipriani et al. (op.cit., p. 274), a medida que o conteūdo 
fengita diminui pelo incremento do grau metamōrfico, o conteūdo paragonita aumenta gradativamente atē certo ponto (representado no diagrama pela curva da temperatura), e então cai rapidamente com o aumento de poucas dezenas de graus centigrados.

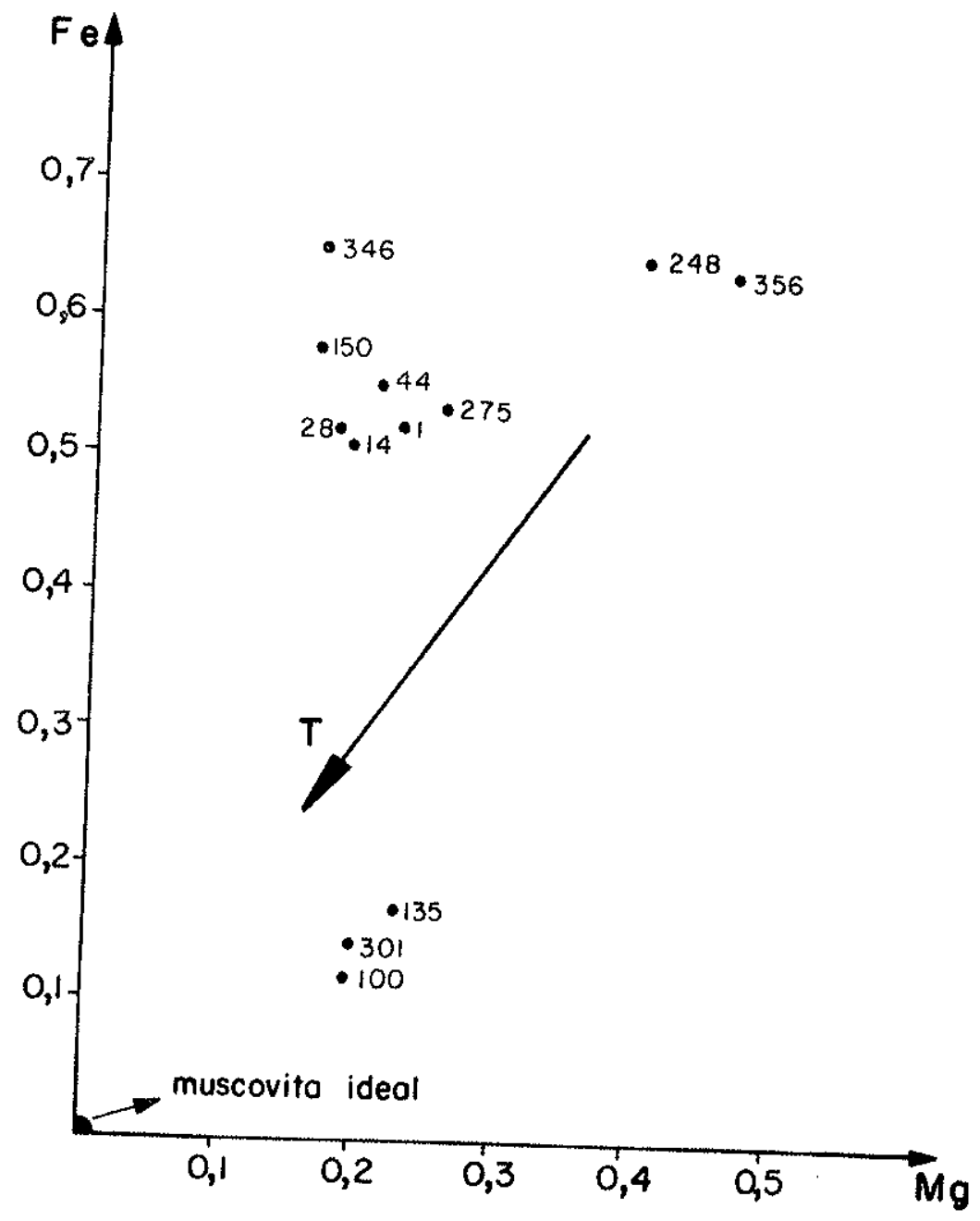

Figura 6 - Relação entre os ïons de Fe e Mg das camadas octaedrais das muscovitas em função da temperatura

A figura 8 correlaciona o conteūdo fengita com a variação de pressão. A construção do diagrama $\vec{e}$ realizada de forma que o efeito da temperatura ocorra principalmente ao iongo da abscissa, e o da pressão essencialmente ao longo da ordenada. As relações da composição da muscovita com a pressão, encontram amplo apoio em estudos experimentais, teöricos e empïri cos, (ver citações em Guidotti e Sassi, 1976, p.12). Numerosos dados mineralögicos e petrolögicos mostram a presença bastante comum de muscovita celadonitica em cinturões metamörficos de al 


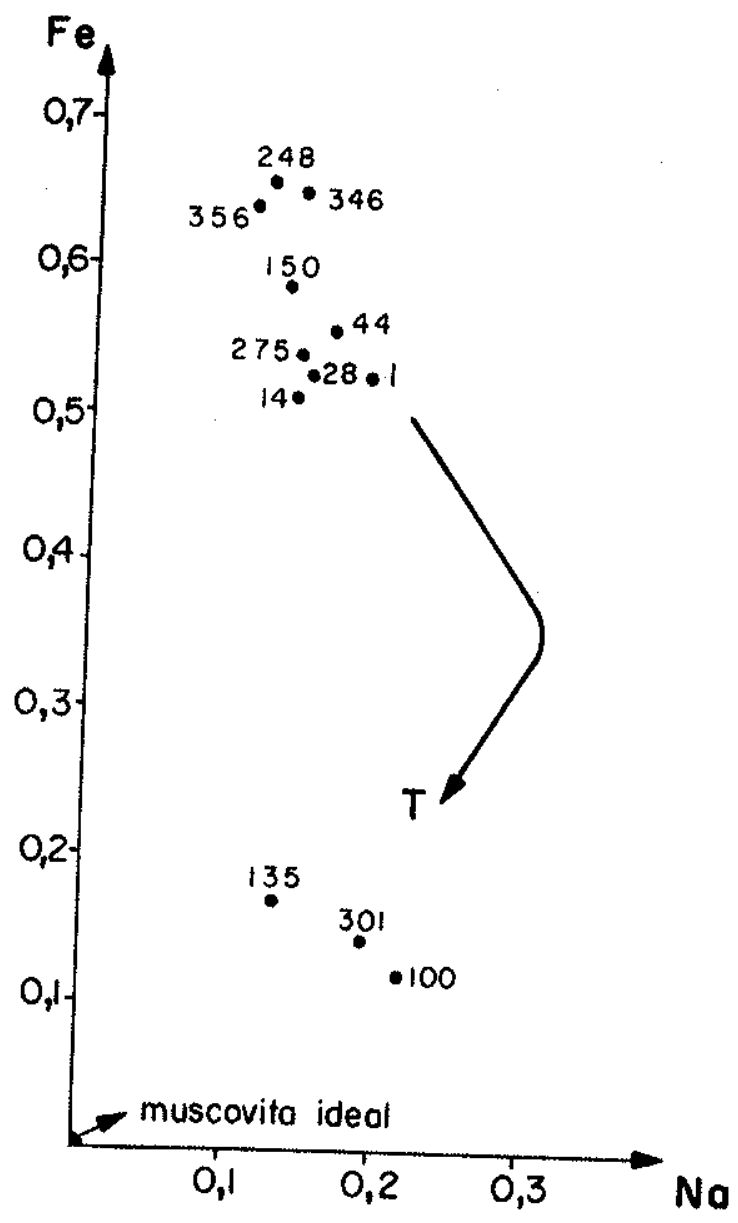

Figura 7 - Relação entre os ions de Fe das camadas octaedrais e de $\mathrm{Na}$ das posições interlamelares das muscovitas em função da temperatura.

ta pressão e baixa temperatura, (entre outros, Miyashiro, 1962 ; Velde, 1965; Sassi, 1972), verificando-se, por outro lado, um continuo decrēscimo da celadonita, na muscovita natural, pela redução da pressão (Cipriani et al., 1971; Seki, 1973, Tabelas 1 e 2). 0 crescente teor do Mg coin o aumento da pressão, deve- se ao fato da fengita apresentar uma estrutura cristalina mais densa que a muscovita ideal, sendo sua formação e sua solução sōlida favorecidas pelas condições de alta pressão.

Encontram-se representados na Figura 8 , os campos determinados por Ciprianj et al. (1971, p.270) com base em cerca de 400 anālises quïmicas de muscovitas disponỉveis na literatura, correspondendo respectivamente a: MA - pressões muito altas (fácies do glaucofãnio xistos); A - pressões altas (fäcies xistos 


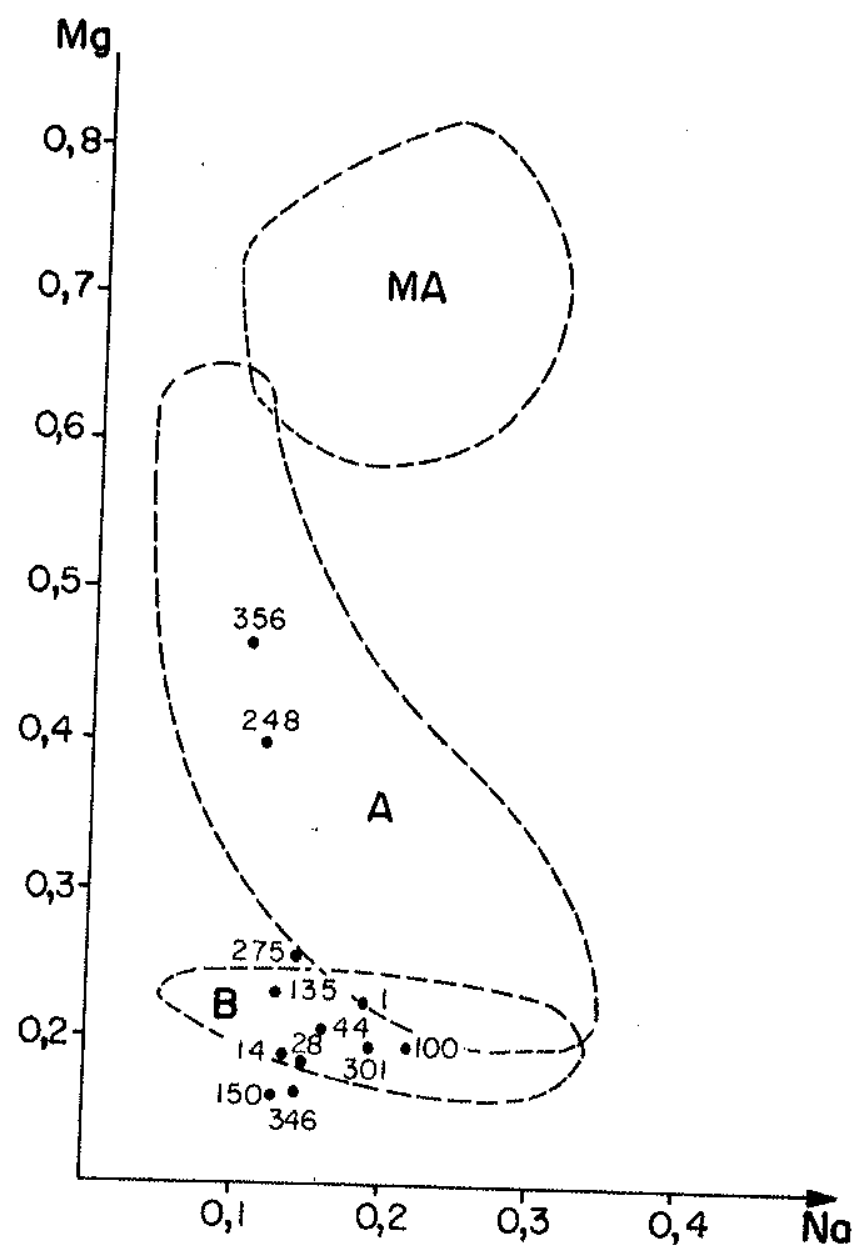

Figura 8 - Relação entre o Mg das camadas octaedrais e o $\mathrm{Na}$ das posições interlamelares como indicador barométrico.os campos representados por MA (pressão muito alta), A (pressão alta) e B (pressão baixa), foram determinados por Cipriani et a1. (1971, p.270).

verdes); e B - pressões baixas (sēries faciais de baixa pressão).

Embora os autores supra citados tenham utilizado praticamente todos os dados disponiveis atē então na literatura, os campos a $\mathfrak{i}$ delimitados não podem ser considerados como de âmb to universal, pois estudos mais recentes, como por exempio, na região de Maine (USA), apresentados por Guidotti (1973,Tabela 1; 1978b, Tabela 2) com paragéneses minerais por eles determinadas como equivalentes ao ponto trïplice da cianita-andaluzita-sillimanita, demonstram que as muscovitas possuem teores de Mg ao redor de $0,1 \%$, isto $\bar{e}$, bastante inferiores ao campo de baixa pres- 
são do referido diagrama. Sendo assim, as informações fornecidas pela Figura 8 , devem ser consideradas apenas como dados relativos à variação da pressão.

0 exame das Figuras 6 e 7 revela, de imediato, que os pontos 100,135 e 301 se aproximam mais da composição da musco vita ideal, o que poderia significar uma temperatura mais elevada para estas rochas localizadas a $W$ da ārea focalizada.

Por outro lado, os demais pontos ocupam uma posição demasiadamente elevada nestes diagramas, formando um extenso hiato em relaçäo aos anteriores, manifestando um enriquecimento pronunciado de Fe naquelas muscovitas. Ainda pela Figura 6, com exceção dos pontos 248 e 356 , aquele mesmo grupo apresenta certa deficiência de $\mathrm{Mg}$ em relação ao Fe.

Como todo o Fe foi calculado como sendo $\mathrm{Fe}^{2+}$, poderia estar havendo uma influência do $\mathrm{Fe}^{3+}$ que participa da solução sōlida fengita-ferro fengita, contribuindo para a elevação destes pontos. Outrossim, a aparente deficiência em Mg poderia estar relacionada ao mesmo fenómeno, ou ainda, segundo Velde (1965, Figura 1), ser devida ao menor envolvimento do $\mathrm{Mg}$ em relação ao $\mathrm{Fe}^{2+}$, em determinadas pressões, aumentando seu envolvimento com o incre mento deste parāmetro. Esta ültima consideração encontra apoió nas posições ocupadas pelos pontos 248 e 356 , nos diagramas das Figuras 6 e 8 .

Comparando-se a distribuição dos pontos nas Figuras 6 e 7 , com a posição dos mesmos na Figura 5, notamos que hā uma correspondēncia fiel entre os trēs diagramas, levando a crer que - conteūdo fengita, nas muscovitas destas rochas, reflete sofrer uma influência direta da composição quỉmica da rocha total.

A observação da Figura 9, tambëm conduz parcialmente a mesma conclusão. Assim, as relações isomōrficas e a passagem para a fengita atravës do mecanismo Si $+M g\left(o u \mathrm{Fe}^{2+}\right) \rightleftharpoons A I^{\mathrm{IV}}+$ $A{ }^{V I}$, deveria provocar um enriquecimento substancial de Al IV nas camadas tetragonais das muscovitas mais pobres em fengita (pontos 100,135 e 301 , que representariam maior temperatura), o que não $\bar{e}$ satisfeito. Isto deve-se ao fato destas rochas : constituirem quartzitos praticamente puros, indicando que o sedimento original era pobre em argila e, consequentemente, com deficiência em alum $\vec{I}$ nio. 


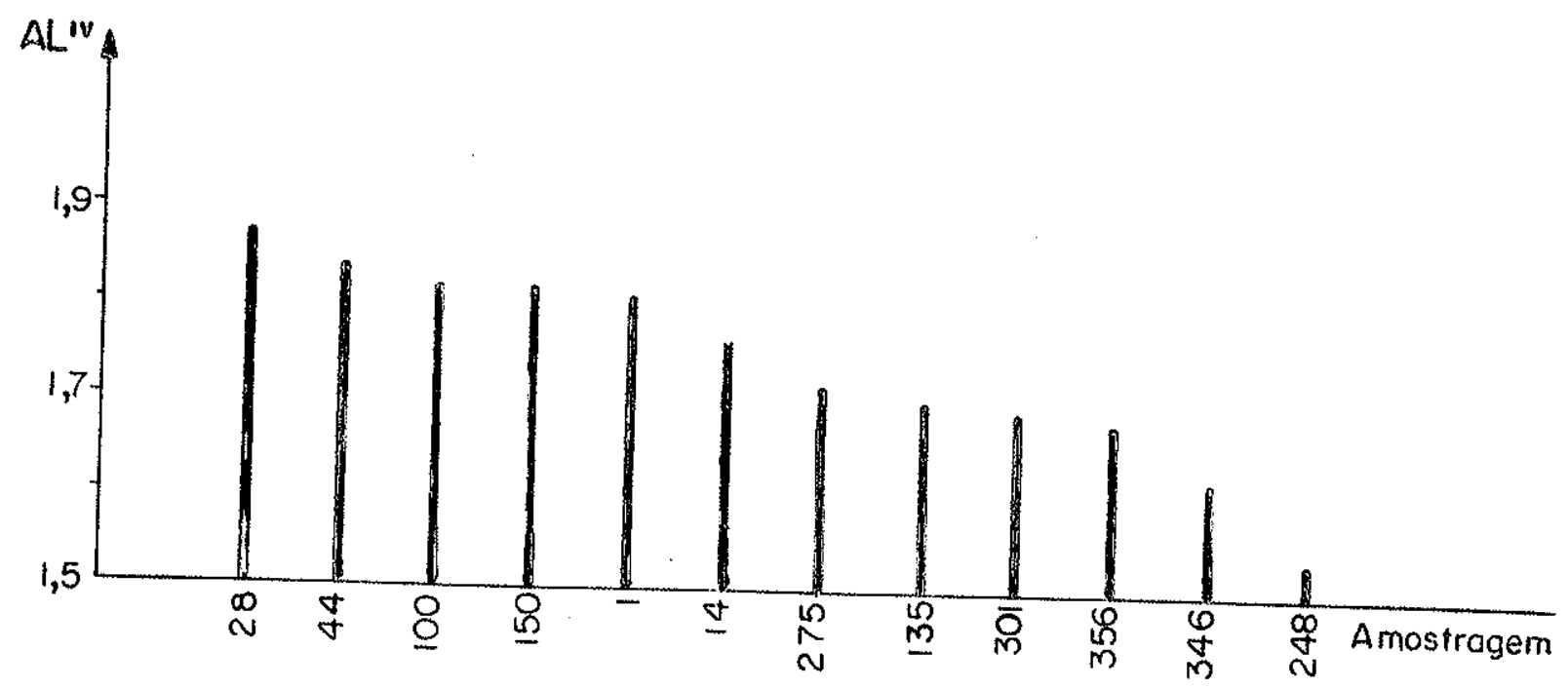

Figura 9 - Variação do alumīnio de coordenação tetraēdrica nas muscovitas da região de Itapira-SP. Cada barra repre senta a mëdia de 100 determinações.

A pressão relativa revelada pela figura 8 , parece ser mais ou menos homogênea em toda a ārea. Apenas os pontos 356 e 248 oriundos de amostras localizadas próximo à falha de jacutinga e de uma de suas subsidiārias, respectivamente, indicam uma provāvel recristalização a pressões mais elevadas e temperaturas menores que as demais amostras.

Pelas considerações acima, torna-se difícil dizer se o conteūdo fengita nas muscovitas, revelado pelos referidos diagramas, reflete realmente um acrēscimo do gradiente metamörfi co no sentido de oeste para leste na região de Itapira. Franco e Coutinho (1957, p.311) estudando um perfil entre Arcadas e Socor ro, situado ao sul da ärea ora em foco, tambēm determinaram que o grau metamörfico na região aumenta de oeste para leste. Contudo, não pode ser descartada a hipōtese de que as litologias de maior grau metamörfico, descritas pelos referidos autores, per tençam ao embasamento do Grupo Amparo.

De qualquer forma, fica demonstrado uma vez mais, que o emprego da muscovita como mineral îndice em āreas metamörficas, não pode ser desvinculado de certas precauções, principal 

mente no que diz respeito à composição da rocha total e/ou sua as
semblēia mineralógica.

\section{V.3.2. Fācies de metamorfismo e evolução petrogenētica}

0 exame das paragēneses das rochas metamōrficas, da ärea em foco, permite estabelecer pelo menos duas fases nituidas de metamorfismo. A predominante, gerada por metamorfismo regional crescente, ē enquadrada seguramente na fäcies anfibolītica, e a outra è resultante de um declinio deste metamorfismo regional com sinais de diaftorese em toda a ārea, chegando a atingir a parte superior da fäcies xistos verdes.

A fäcies anfibolitica manifesta-se nas diversas $1 i-$ tologias pelas seguintes paragêneses tïpicas:

1. Nos biotita e hornblenda gnaisses predomina a as sociação hornblenda-biotita-oligoclāsio (intermediārio a bäsico)epĩdoto-quartzo \pm microciinnio. Subordinadamente, nas porções $\mathrm{N}$ e E da ārea, bem como nos gnaisses granīticos a SE, aparece a associação diopsỉdio-hornblenda-(e/ou biotita)-andesina intermediaria - epidoto-quartzo \pm microclīnio. A presença de diopsidio, a média alcalinidade dos plagioclásios e a frequência com que aparece ep $\mathbf{i}$ doto acompanhando oligoclāsio e andesina, indicam, para estas rochas, condições brandas a no māximo mēdias da fācies anfibolītica.

2. Nos diopsidio meta-hornblenditos situados a $S W$ da Fazenda Cristālia, a associação hornblenda-diopsídio é caracte rỉstica para a parte média à alta da fācies anfibolïtica (Miyashi ro, 1975, p. 260), jā que o diopsỉdio não se desenvolve em metaultramafitos nas condições mais brandas desta fäcies. Por “outro lado, a presença de andesina anfibolitos, que tambēm ocorrem nestes locais com a paragēnese andesina-hornblenda \pm biotita \pm titani ta \pm (epidoto), exclui a possibilidade de tratarmse da parte mais alta da fäcies anfibolitica, ou metamorfismo de grau alto de Winkler (1976), que permite enquadrä-las como sendo, possivelmente da parte mēdia da fäcies anfibolitica.

3. As rochas quartzĩticas são bastante "frequentes na região. Embora tenham composição um tanto variāvel, com a asso ciação quartzo-muscovita \pm oligoclāsio \pm microclīnio, são rochas pouco sensîueis às reações metamörficas. Contudo, sua alternãncia 
com os biotita e hornblenda gnaisses regionais e a frequente asso ciação com leitos e lentes de anfibolitos e mesmo meta-hornblendi tos, principalmente na sinclinal a NE de Itapira, permite : concluir que os quartzitos foram tambëm gerados na fäcies anfiboliti ca. A não observāncia de sillimanita em sua paragênese, ;indica que estas rochas não atingiram a parte mais elevada da fäcies anfibolitica, ou o metamorfismo de grau alto de Winkler (1976).

4. A constatação de inicio de anatexia nos biotita e hornblenda gnaisses a $S W$ e $N$ da àrea mapeada, evidencia que 0 metamorfismo nestes locais atingiu as condições mais enērgicas da fäcies anfibolitica. Embora a muscovita seja um mineral raro: nos gnaisses regionais sua preserça $\bar{e}$ relativamente frequente no mela nossoma destes gnaisses anatexiticos, o que indica segundo Winkler (1976, p.63), que a pressão d'ägua excedeu a $3,5 \mathrm{~kb}$, e que a temperatura nesta pressão ē de aproximadamente $6609 \mathrm{C}$.

A diaftorese sobreposta ao metamorfismo mais energi co, afetando toda a região de Itapira, pode ser constatada nas ro chas gnäissicas de um modo geral por numerosas reações, tais como: diopsidio $\rightarrow$ hornblenda, hornblenda castanha $\rightarrow$ hornblenda verde $\rightarrow$ clorita, hornblenda $\rightarrow$ biotita, hornblenda $\rightarrow$ clorita, biotita $\rightarrow$ clo rita, granada $\rightarrow$ clorita, etc. Estas reações que estão : acompanha das de generalizada sericitização do plagiocläsio, indicam que o metamorfismo retrōgrado atingiu parcialmente as condições da fācies xistos verdes. Tambēm os anfibolitos exibem sinais de retrometamorfose com o desenvolvimento de clorita e plagioclásio sericitizado, seguido da formação de epĩdoto. Ainda, nos diopsĩdio an fibolitos è característica a transformação do diopsidio em horn-
blenda.

como è o caso dos meta-pecão tremolita-talco em rochas magnesianas, segundo Deer et al (1977 tos verdes, o que vem confirmar a hipótese da região, ter sido afetada por fenōmenos de diaftorese, apōs ter sofrido um metamorfismo de grau mais elevado.

As observações petrogrāficas das rochas metamōrficas da região de Itapira, evidenciam que as mesmas foram geradas por metamorfismo progressivo na fäcies anfibolitica, com alguns nücleos atingindo inicio de anatexia no Ciclo Transamazōnico, ou 

nologia). Este metamorfismo progressivo foi acompanhado de forte deformação tectónica, a qual foi superada pela recristalização.

freram as seguintes influencias: no Ciclo Brasiliano, as rochas so-

- Localmente, a migmatização por injeção de material granitico.

- Formação de biotita, a partir de mäficos prē-exis tentes, e de hornblenda a partir de piroxēnios.

- Retrometamorfismo generalizado que atingiu parcialmente a fäcies xistos verdes.

- Intensa deformaçăo pös-cristalina que levou à for mação de cataclasitos, milonitos e ultramilonitos.

Tais derivações coadunam-se com as descritas por Wernick (1967, 1977, 1978a) para äreas circunvizinhas de Itapira. 


\section{ASPECTOS ESTRUTURAIS}

No contexto regiona1, a ärea mapeada pertence a faixa de rochas metassedimentares situadas entre o complexo granitico-migmatitico de Pinhal (Ebert, 1971), localizado no Bloco Pinhal (Penalva e Wernick, 1973b) ao norte,e o de Socorro (Wernick, 1967) pertencente ao Bloco Juridiai (Hennies et al., 1967 ; Hasui et al., 1969; Wernick e Penalva, 1973), ao Sul (Figura 4).

0 limite desta faixa com o bloco de Pinhal e feito por uma zona de falhamento verificado por Ebert (1968) e denominada Falhamento de Jacutinga por Wernick e Penalva (1973) e Ebert (1974), com direção geral N 70-80E. Constitui o limite entre os blocos de Jundiaí e de Pinhal.

0 limite sul da faixa metassedimentar, com o comple xo de Socorro, $\vec{e}$ considerado por Ebert (1968) como tectónico atravēs do Falhamento de Socorro, com direção NNE a oeste do complexo, infletindo para $E-W$ entre Ouro Fino e Pouso Alegre, a nor
te do Complexo.

\section{VI.1. Fases de Dobramento}

Fiori et al. (1978, 1980), Fiori (1979), Wernick e Fiori (1979) e Wernick et al. (1979) trabalhando na região nordeste do Estado de São Paulo e no sul do Estado de Minas Gerais, apresentaram, para a região, uma evolução estrutural policiclĩca com a caracterização de pelo menos trēs fases regionais de dobra mento com direções estruturais ENE-EW; N-NW e NNE - NE, atribuĩdas, respectivamente, aos Ciclos Transamazōnico, Uruaçuano e Bra siliano. Principalmente em Fiori (1979), encontram-se descritos detalhadamente os padrões de interferência resultantes desta superposição estrutural.

Com o intuito de integrar a região, ora mapeada, no contexto da evolução estrutural regional, serä feita breve carac terização das diversas fases de dobramentos que a afetaram.

Assim, na ärea de Itapira, foi possível o reconhecimento nitido de 3 fases de dobramento e, com ressalvas, de mais uma. Estão excluidas destas 4 fases, consideradas de caräter regional, fases subsidiärias tais como: dobras de arrasto, "kinking", etc. As 3 fases acima mencionadas, são facilmente re- 
conhecidas a nivel da carta geolōgica, nas associações litolōgicas que apresentam intercalações de leitos ou camadas de quartzi tos, como pode ser visto no mapa litolögico-estrutural anexo.

1. A fase de dobramento duvidosa refere-se aos gnaisses anatexiticos com isōcrona verdadeira de $2.230 \pm 39 \mathrm{~m}$. a. (Figura 22), localizada na rodovia Itapira-Jacutinga a nordeste do Vilarejo de Sapucai, podendo tratar-se de possiveis eventos referíveis ao Ciclo jequié. Estes gnaisses anatexiticos exibem dobras irregulares, com zona apical espessada, e denotam orjgem dominantemente por fluxo num meio de elevada plasticidade.Ao nível atual dos conhecimentos adquiridos na ārea, não ē ainda possivel decidir se esta fase de dobramento ē anterior à segunda fa se de deformação ou se resulta da anatexia que a sucedeu. Contú do, Fiori (1979, p.93 e seguintes) menciona rochas anatexiticas do Complexo de Silvianöpolis, localizadas nos arredores da cidade homōnima no sul do Estado de Minas Gerais, como representando, possivelmente, o embasamento do Grupo Amparo. Ai, o referido autor descreve gnaisses fitados e bandeados em contatos bruscos com gnaisses anatexiticos, sem falhamentos, onde pode-se notar que a estrutura migmatitica prē-existente ē nitidamente transpos ta por uma foliação mais nova, originada nos metassedimentos do Ciclo Transamazōnico.

A resolução deste problema, na ārea em foco, repre sentarā estudos adicionais geocronolōgicos e estruturais de deta The, estes ültimos destinados a verificar se estas rochas foram cisalhadas e transpostas por ação da segunda fase de dobramento.

2. A segunda fase de dobramento, a mais intensa da ärea, caracteriza-se pelo desenvolvimento de dobras isoclinais. Conforme jā descrito em capitulos precedentes, distingue-se por toda a ärea uma foliação metamōrfica bem desenvolvida, paralela ao acamamento, podendo ser denominada de xistosidade, gnaissificação ou simplesmente foliação, conforme o tipo litolōgico em que ocorre. Essa foliação, tida como desenvolvida nesta fase, originou-se por dobramento isoclinal, o qual deu origem a uma fo liação plano-axial paralela ao antigo acamamento sedimentar. Tra ta-se, portanto, de uma foliação de transposição, conferindo às rochas um carāter cataclāstico generalizado, bem evidenciado pela cataclase e estiramento dos cristais, principalmente de quart zo e feldspato, ao longo dos planos de foliação. Entretanto, 10- 
calmente, as rochas exibem sinais mais ou menos patentes de recristalização, com desenvolvimento de textura blasto-cataclästica indicando que o fluxo de calor superou a fase principal de de formação cataclästica. o mecanismo que originou essa foliação de transposição, encontra-se bem elucidado no trabalho de fiori (1979, p.66 e seguintes).

Os sinais deste dobramento estão preservados principal mente sob a forma de pequenas dobras isoclinais, caracterizadas por um forte espessamento dos āpices e um consequente adelgaçamento nos flancos. Neste ültimo caso, originaram-se dobras intra foliares disruptas. 0s āpices dessas dobras apresentam ainda uma crenulação bem desenvolvida, paralela à superfície axial, sendo concordantes com a foliação observada nas rochas adjacentes. Assim, os traços axiais desta fase de dobramento são paralelos à foliação das rochas da ārea.

Dobras desta fase, em escala de afloramento, não são muito comuns, ocorrendo de uma forma isolada e esparsa, devendose limpar cuidadosamente os afloramentos, perpendicularmente a foljação, para que sejam descobertas.

A superficie axial dessas dobras não apresenta uma inclinação definida, tendo-se visto dobras com a superficie axial variando de horizontal atē vertical, devido ao redobramento a que foram submetidas. São dobras desenhadas pelo antigo acamamen to sedimentar, possivel ainda de ser identificada pela alternância de camadas de composição, granulometria e constituição diferentes.

Seus traços axiais, que correspondem ao traço da folia ção e do acamamento no mapa litolögico-estrutural anexo, variam bastante na direçăo, devido não somente aos redobramentos posteriores, como tambëm pela rotação de blocos causados por uma intensa tectónica ruptural.

3. Em algumas partes da ārea em foco, uma terceira fase de dobramento provocou o redobramento da foliação gnāissica plano axial da fase de dobramento anterior.

A Figura 10 mostra a forma de uma estrutura a leste da Fazenda do Jardim, situada ao sul da rodovia Itapira-Lindóia. Co mo pode-se notar, os traços axiais da $3 a$. e da $2 a$. fases de dobramento, dispõem-se quase paralelamente, a não ser no äpice da 
3a. fase, quando o traço axial da 2 a. cruza com o traço da $3 a$. for mando um āngulo de quase 900 entre si. 0 paralelismo entre os traços axiais sugere que o redobramento foi intenso, produzindo dobras do tipo fechadas a isoclinais. Portanto, a superposição da 3a. fase de dobramento sobre a $2 a$., tambēm de carāter isoclinal, deu-se em uma direção aproximadamente ortogonal em relação a $2 a$. fase.

Mesmo a nĩvel de fotointerpretação pode-se observar, na referida estrutura, a natureza isoclinal do dobramento da 3a. fase, com flancos inclinados para sudoeste. Estes fatos encon tram apoio nos dados de campo, tendo-se verificado dobras isoclinais da $3 a$. fase, a nivel de afloramento. Ainda pelas fotografias aēreas, os traços da $2 a$. fase são identificados por seu aspecto algo mais irregular e por se dobrarem em torno dos traços da $3 a$. fase. Na verdade, o traço axial da 2 a. fase pode ser observado acompanhando-se os flancos da estrutura, pois ē paralela à foliaçăo gnaíssica, enquanto que o traço axial da $3 a$. fase praticamente divide a estrutura em sua parte mëdia, com o traço axial da 2a. fase dobrada à sua volta.

os planos e traços axiais das dobras desenvolvidas nesta fase, tēm direção em torno de NNW-NW, às vezes mais ou menos deslocada, devido a movimentos de rotação dos blocos tectônicos. No caso da estrutura da Figura 10, a orientação geral de seu plano axial foi estimada como sendo N10W/75SW, com o eixo merguThando 75 para SW.

Entre outras estruturas similares presentes ärea, destaca-se a situada a sudoeste da Fazenda da Fortaleza.Dobras a nĩvel de afloramento, desta $3 a$.fase, são extremamente raras na ārea e mostram orientação um tanto variāvel, embora parecam predominar aquelas com planos axiais orientados segundo o qua

Sabe-se que o dobramento em questão è da $3 a$. fase, porque estas são desenhadas pela foliação de transposição, dispos ta paralelamente ao bandeamento de origem sedimentar, e resultante de dobramento isoclinal em fase anterior, denominada de $2 a$. fa se. Dessa forma, fica patente o redobramento, caracterizando uma evolução pelo menos polifásica para as rochas da ärea. Como o dobramento da $3 \mathrm{a}$. fase tambēm ē de natureza isoclinal, ē de se espe 


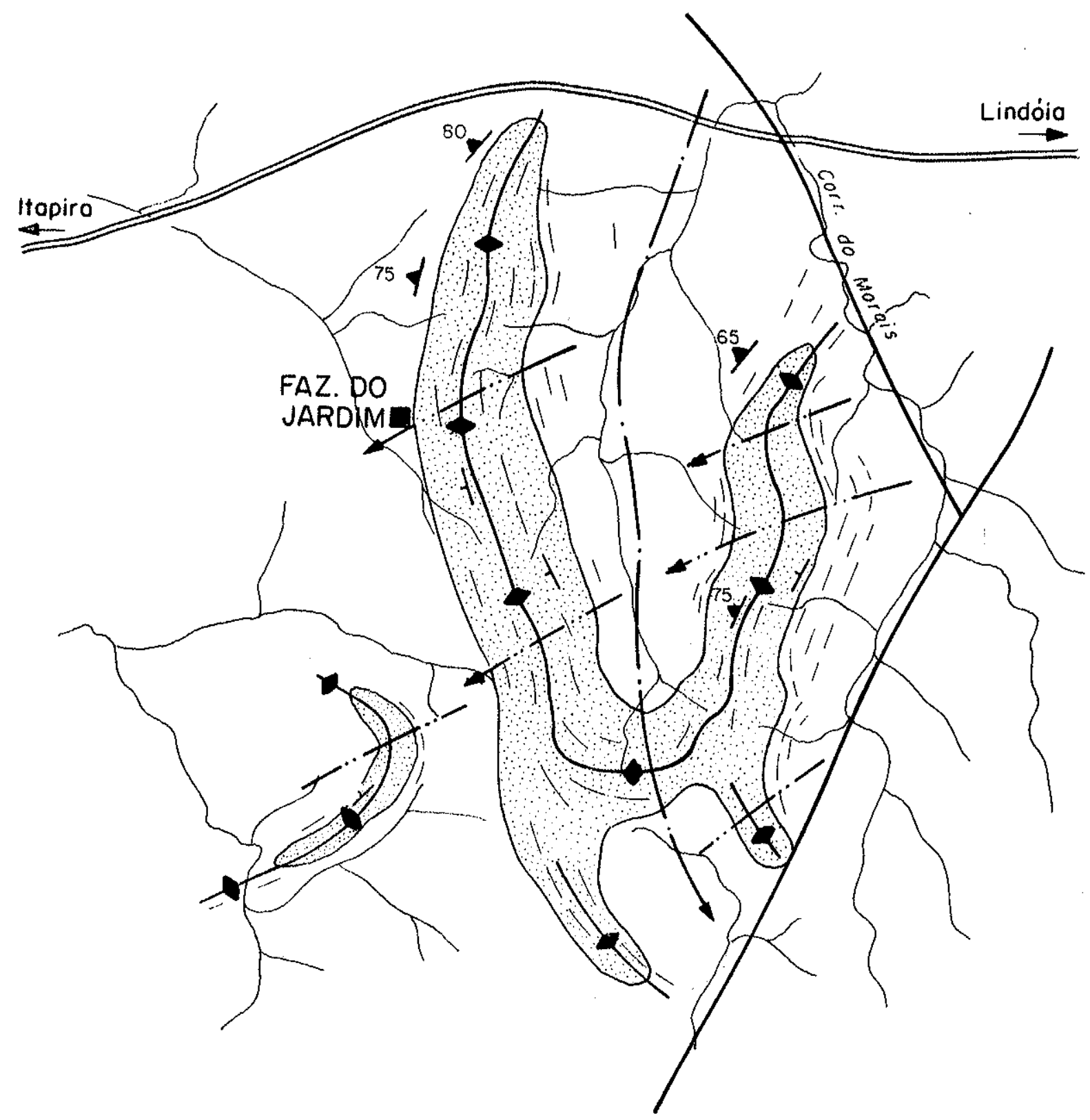

LEGENDA

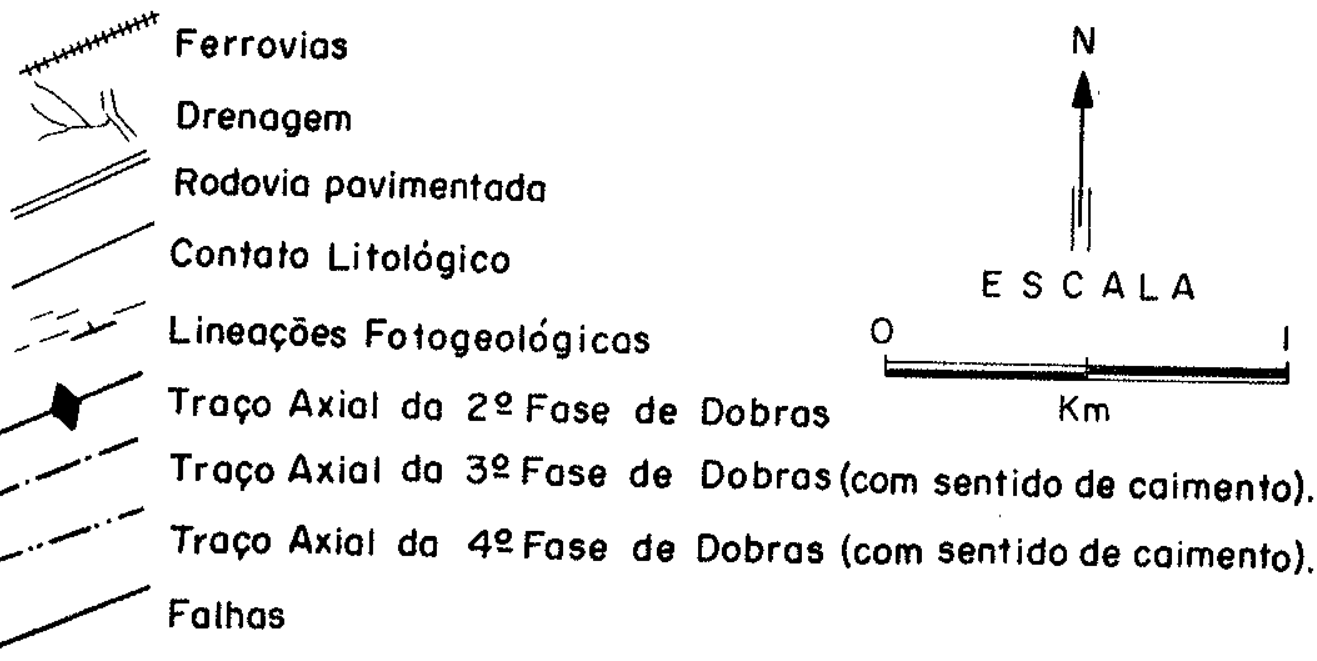

Quartzitos variados associados com biotita e/ou hornblenda gnaisses, biotita xistos e gonditos. 
rar que tenha, originado por sua vez, uma foliação paralela à su perficie axial. Entretanto, não foi verificado o desenvolvimento de foliação plano axial nĩtida, nem patente recristalização pōsdeformacional, sugerindo ter a deformação superado a fase de flu xo de calor. Provavelmente, em outras äreas onde ocorram rochas de granulação mais fina como, por exemplo, meta-siltitos e metaargilitos, uma nova foliação plano axial tenha se desenvolvido de forma mais evidente.

Na estrutura da figura 10 , e em outras da mesma fa se, pode-se observar ainda um outro tipo de dobra afetando tanto os traços axiais da $2 a$. como os da $3 a$. fase de dobramento. Säo dobras mais recentes, reieríveis à $4 a$. fase de dobramento, pois afetam as duas sēries anteriores, produzindo pequenas ondulações nos flancos das dobras da $2 a$. e $3 a$. fases.

Estas estruturas ressaltam no relevo por apresenta rem normalmente camadas mais ou menos espessas de quartzitos, que ocorrem intercalados concordantemente com os biotita e/ou hornblenda gnaisses, tornando-se facilmente identificäveis em foto grafias aēreas, ou mesmo no campo.

4. Uma quarta fase de dobramento bastante evidente em toda ärea mapeada, pode ser verificada a nīvel do mapa 1 itoló gico-estrutural anexo, seja atravēs de dobras suaves produzindo ondulações nos flancos de fases anteriores, seja atravēs de dobras denotando maior intensidade, originando diversos sinformes e antiformes. Esta fase de deformação plāstica gerou dobras com direção NE-SW.

As ondulações que se manifestam nos flancos tanto das dobras da $2 a$. como da $3 a$. fase (como pode facilmente ser verificado na estrutura a leste da Fazenda do Jardim, Figura 10), são do tipo concēntricas e abertas. Devido à elevada inclinação regional da foliação metamōrfica das rochas, essas dobras apresentam o eixo com forte caimento, tanto para NE como SW, conforme o flanco das dobras anteriores em que se situem. Como reflexo de sua pequena intensidade, os eixos destas ondulações são trans versais em relação aos eixos da $2 a$. fase de dobramento. Embora a direção preferencial do traço axial destas inflexões seja $N E$, elas apresentam variações ou para $N-S$ ou $E-W$, devido à movimenta ção de blocos por influẽncia das diversas falhas que cortam toda a ärea. No mapa litológico-estrutural anexo, essas dobras aber- 
tas podem ser notadas pelas ondulações das linhas de forma estru tural deduzidas da fotointerpretação,principalmente quando estão presentes leitos de quartzitos.

As estruturas sinformes e antiformes, de expressão variāvel na ārea, resultam de dobras tambēm de natureza concēntrica, geradas por processo flexural. Dentre estas, o exemplo mais expressivo $\bar{e}$ a estrutura sinforme de Itapira (Fig.11), situada imediatamente a leste da cidade homōnima.

A constatação de dobras da $2 a$. e $4 a$. fase e tarefa bastante facilitada, mesmo no campo, quando se tem em mente que as dobras da $4 a$. fase são desenhadas pela foliação de transposição da $2 a$. fase. Conforme jā referido anteriormente, a foliação de transposição foi gerada por um dobramento isoclinal intenso, tendo-se desenvolvido paralelamente à superfïcie axial das dobras da $2 a$. fase. Assim, as dobras da $4 a$. fase são obtidas pelo dobramento da superfície axial e dos flancos das dobras da $2 a$. fa se.

A forma da zona periclinal da estrutura sinforme de Itapira, esquematizada na Figura 11 , deve-se à inclinação relativamente elevada do eixo da $4 \mathrm{a}$. fase de dobramento, estimada graficamente em 500 para SW. Aí, o traço axial da 2 a. fase de do bramento que acompanha a foliação metamörfica, apresenta-se irre gular e fragmentado, enquanto o traço axial da $4 a$. fase ē bastan te constante e regular na sua direção. Considerando-se o paralelismo entre os traços axiais da $2 a$. e $4 a$. fases de dobramento, que ocorre ao sul do "nariz" da referida estrutura, e tendo- se em vista que a $2 a$. fase é de natureza isoclinal e a $4 a$. ë do tipo aberta e concēntrica, somos levados a admitir que o dobramento da $4 a$. fase é coaxial em relação ao da $2 a$. fase. Assim,a pronunciada perpendicularidade entre os referidos traços axiais no "nariz" do sinforme, nada mais é do que um reflexo da elevada in clinação do eixo da $4 a$. fase. Esta conclusão de redobramento coá xial ē compatĩvel com as observações de Fiori (1979, p.96) para a região de Silvianōpolis, no extremo sul do Estado de Minas Gerais.

A natureza flexural desta $4 a$. fase de dobramento pode ser constatada no pröprio sinforme da Itapira, onde foi efe tuado um corte de talude, na rodovia, para a construção do novo trevo de Itapira. Aĩ, acompanhando as superfícies dos planos de 



Ferrovias

Drenagem

Rodovia povimentodo

Contoto Geológico

Contato Geológico Inferido

Folha

Falho Inferido

Lineaçōes Fotogeológicas

E S C A LA

Atitude de Foliaçōo Metamórfico

Traço Axial da 20 Fose de Dobras
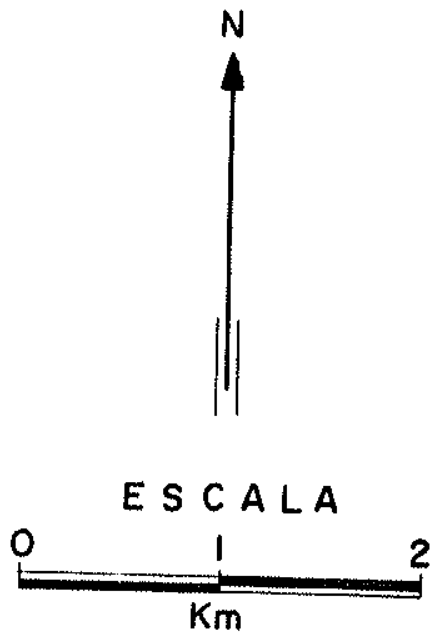

$\mathrm{Km}$

Axial Sinformal da $4 \%$ Fase de Dobras (com sentido de caimento).

Aluviōo e Eluviōo.

Quartzitos variados associados com biotita e/ou hornblenda gnoisses, biotito xistos a gonditos.

Biotita e/ou hornblenda gnaisses com intercalacōes de quartzitos variodos, cos e raros g, anfibolitos, biotita gnaisses porfiroblásticos, gnaisses graniti-

Biotito e/ou hornblenda gnoisses e biotito xistos com intercoloçōes de onfibolitos e gonditos.

Meta-hornblenditos e ultramáficas. 
gnaissificação dos muscovita quartzitos, ocorrem estrias de des1 izamento flexural com ate $0,5 \mathrm{~cm}$ de profundidade, apresentando direções entre N20-30E, com inclinação entre 90 e 150 para SW.

Aparentemente, nesta ūitima fase de dobramento tam bëm năo ocorre conspīcuo desenvolvimento de foliação plano axial e recristalização pós-deformacional. As paragēneses das rochas afetadas, da fäcies xistos verdes, são indicativas de um baixo fluxo de calor e o padrão de deformaçăo denota certa rigidez das rochas deformadas. Na estrutura sinforme de Itapira, foi verificado localmente, um cerrado fraturamento do muscovita quartzito paralelamente ao plano axial destas dobras, com alguns minerais de muscovita mostrando a mesmo orientação. Portanto, um estudo mais detalhado em äpices de dobras em biotita xistos, que ocorrem intercalados nos muscovita quartzitos, pode revelar o desenvolvimento de tal foliaçăo.

Medidas realizadas nas raras dobras a nivel de afloramento no sinforme de Itapira, apresentaram atitudes bastante variaveis, com planos axiais entre N20-60E, com altos mergulhos tanto para NW quanto para SE. Os ejxos apresentam inclina ção entre 30 e 500 para SW.

A 4 a. fase de dobramento, como no caso da anterior, è mais facilmente percebida devido às intercalações de quartzitos que sobressaem na topografia.

0 reconhecimento de possivelmente 4 fases de dobra mento com caracteristicas distintas sugere, para a ärea de Itapi ra, a existência de uma evolução tectônica policĩclica. Embora coadune-se com os resultados obtidos por Fiori et al. (1978) e Fiori (1979) ao nĩvel regional, no qual a ärea em foco se acha inserida, não pode ser descartada a hipötese de que algumas fam ses de dobramento sejam, em realidade, deformações polifäsicas ligadas a um ou mais ciclos, como sugerido por Hasui e Sadowski (1976) para a região de são Paulo, jä que a sequēncia das 4 fases de deformação são compatīveis com dobramentos que ocorrem em sistemas rochosos caracterizados por um enrijecimento progressivo. Entretanto, o caräter polimetamörfico das rochas sucessivamente deformadas, $\bar{e}$ indicativo de vārios fluxos de calor de carä ter regional, sob regimes de temperatura e pressão distintas, que encontram os seus reflexos em isōcronas $\mathrm{Rb} / \mathrm{Sr}$ e datações $\mathrm{K} / \mathrm{Ar}$ re 
feríveis a värios ciclos (capĩtulo VII).

Assim, a $2 a$. fase de dobramento, que è a responsāvel pela foliação de transposição das rochas metamōrficas da fācies anfibolitica, $\vec{e}$ comprovadamente de idade transamazōnica. Jä a $4 a$. fase de deformação, que provoca o redobramento das $2 a$. e $3 a$. fases, afetando rochas com paragēnese tambēm dos xistos verdes (cuja fäcies, corresponde, conforme datações K/Ar, ao metamorfismo retrógrado ocorrido no Brasiliano), é possivel de ser enquadrada como desenvolvida no Ciclo Brasiliano.

A deformação plästjca que gerou as dobras da 4 a. fase de dobramento, com direção geral NE-SW, foi seguida por deformações rígidas que originaram, entre outras, o falhamento transcorrente de Jacutinga.

A la.fase que seria a mais antiga e de carāter duvidoso, correlacionada tentativamente ao Ciclo Jequiē, embora tenha sido constatada por Fiori (1979) no Complexo de Silvianōpo lis ao norte da area ora mapeada, requer estudos adicionais estruturais e geocronolōgicos de detalhe para a sua comprovação no referido Ciclo.

A $3 a$. fase de dobramento, que redobrou a $2 a$. fase e foi afetada pela 4 a, não mostra evidēncias de recristalização pós-deformacional, dificultando a sua correlação com possíveis ciclos metamörficos. No entanto, sua direção geral NW-SE, caracteristica de uma fase de dobramento de ámbito regional, correlacionada tentativamente ao Ciclo Uruaçuano por Fiori et al. (1978), adicionada às datações $\mathrm{Rb}-\mathrm{Sr}$ realizadas na estrutura situada a SW da Fazenda Fortaleza, que apresentaramidades ao redor de $1.140 \pm 88 \mathrm{~m} . \mathrm{a}$. (Figura 23), sugerem a possibilidade desta fase estar relacionada a um evento intermediärio aos ciclos Transamazónico e Brasiliano.

\section{VI.2. Estruturas Locais}

\section{VI.2.1. Procedimento de campo e tratamento dos dados}

Os dados estruturais resultantes do mapeamento da ärea em questão, evidenciam padrões de deformação muito complica dos. Isto resulta, provavelmente, do caräter polifásico e tambëm 
do magmatismo, migmatização e fraturamento intenso que afetaram as rochas regionais.

Tendo-se em vista o grande nūmero de pequenos blocos resultantes do intenso falhamento que afetou a ārea, o que por värios motivos impossibilita a anälise de cada dominio individualmente, optou-se embora de modo precārio, pela subdivisão da ärea em setores. Assim, o mapa litolögico-estrutural foi divi dido em 4 setores (Figura 12) com dimensões aproximadamente simi lares, representando de forma global os principais dominios estruturais da ārea em foco.

Conforme pode-se ver na Figura 12, o Setor 1 repre senta a faixa que bordeja as rochas sedimentares da Bacia do $\mathrm{Pa}-$ ranä; o Setor 2, a faixa centro-sul, envolvendo o sinforme e demais estruturas a leste de Itapira; o setor 3 , a faixa a leste da ärea; e o setor 4, a porção norte, mais diretamente afetada pelo falhamento de Jacutinga.

Aproximadamente 1884 medidas estruturais foram obtidas na ārea mapeada, sendo estes valores tratados de maneira a facilitar o estudo do padrão tectōnico da região. 0 inventārio dos parāmetros estruturais foi feito sistematicamente, quando possivel, em todos os afloramentos, sendo agrupados nas seguintes categorias: foliação, acamamento, juntas, falhas principais e subsidiārias, foliação em milonitos, planos axiais, eixos de dobras e veios de quartzo e pegmatitos. Em particular, a foliação (gnaissificação, xistosidade e foliação de transposição) e as juntas para cada setor, além dos veios de quartzo e pegmati tos, falhas e foliação em milonitos de toda a ārea, tiveram seus polos lançados em diagramas de igual ärea (Schmidt-Lambert). A avaliação estatīstica dos dados foi feita pelo mëtodo gräfico, sendo os diagramas de contorno no hemisfërio inferior, obtidos a partir da rede de integração LAMPRO 212 de Braun (Braun, 1969).

\section{VI.2.2. Elementos estruturais}

\section{Fol i ação}

Os metamorfitos da região de Itapira exibem, como referido anteriormente, concordancia entre o acamamento original e a foliação de transposição. Boas exposições de concordância en 


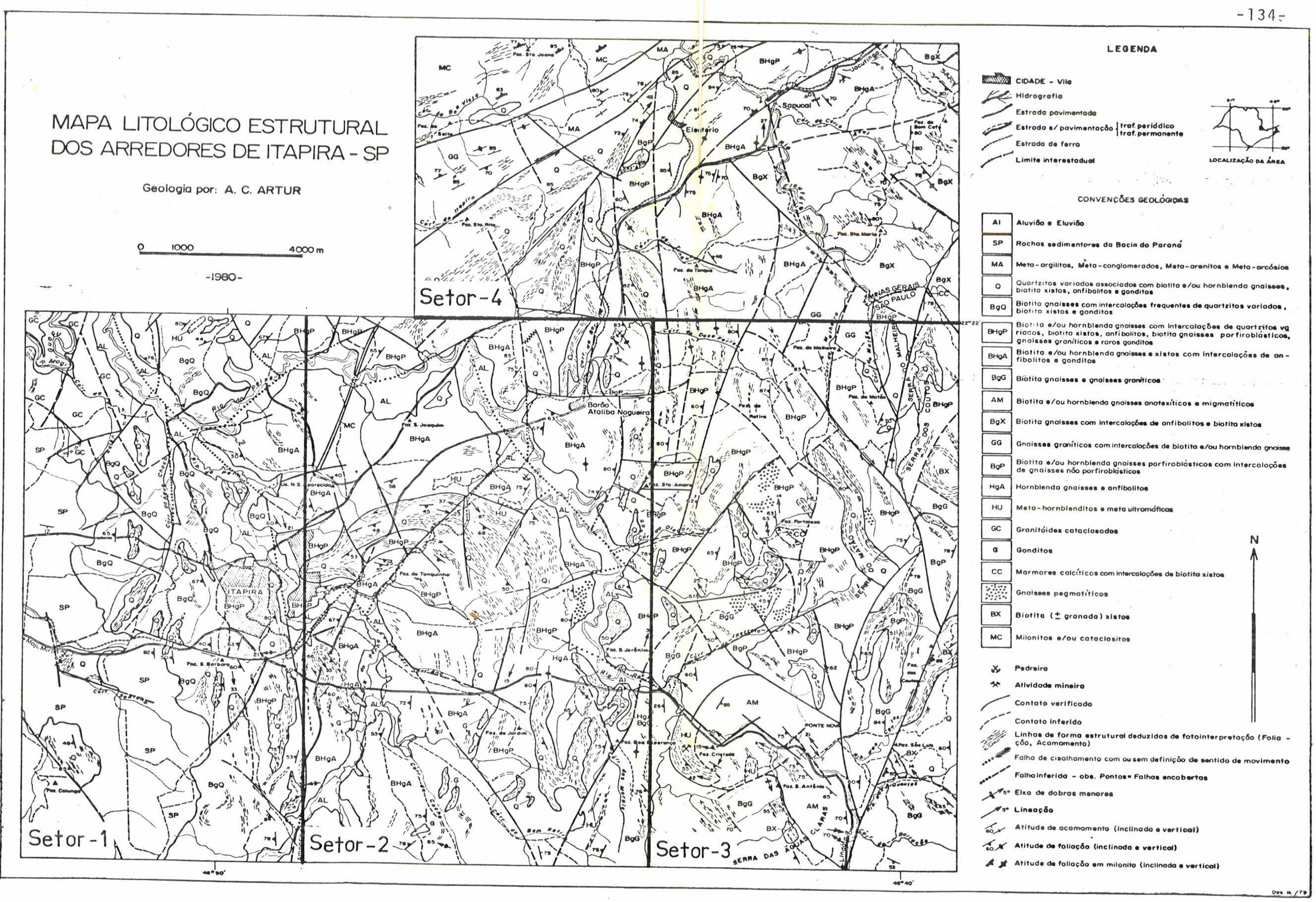

figura 12 - divisá da Area mapeada "Em setores", para fins de caracterizaçao de elementos estruturais ( L Limite entre setores) 
tre o acamamento e a foliação podem ser vistos, principalmente nas associações litológicas (B), (C) e (D), onde os contatos entre leitos e camadas de quartzitos, gnaisses graniticos, biotita xistos e gonditos com o gnaisse regional são bastante frequentes.

Para auxiliar na interpretação da atitude preferen cial da foliação, foram elaborados os diagramas de contorno presentes nas Figuras 13 e 14, com os diversos māximos deduzidos 1 istados em ordem de frequência para cada Setor na Tabela 4. Estão excluídos, evidentemente, o acamamento e a estratificação das rochas sedimentares da Bacia do Paraná, bem como a clivagem ardosiana dos metassedimentos da Formação Eleutērio.

os dados obtidos pela integração dos mäximos deduzidos dos diagramas de contorno (Tabela 4), mais as informações fornecidas pelo mapa litológico-estrutural anexo e pelas fases de dobramentos anteriormente descritas, evidenciam uma pronuncia da variação na orientação da foliação para a ārea de Itapira.

Assim, o estereograma do Setor 1, visto como um todo, apresenta simetria triclīnica, o que é tîpico de āreas de redobramento. 0 māximo I, exibindo uma ūnica concentração de pólos, e com atitude da foliação NS/55W, é sugestivo de dobramento isoclinal simétrico, devendo representar a $2 a$. fase de dobramento, responsāvel pelo desenvolvimento da foliação plano axial, des crita anteriormente. 0 māximo II com a atitude da foliação N60E/ $56 \mathrm{NW}$, e o máximo III com N38W/78 NE e N45W/39NE respectivamente, poderiam representar a reorientação da foliação causada pela 4 a. fase de dobramento, que teria produzido inflexões nos flancos das dobras da $2 \mathrm{a}$. fase, jā que não foram reconhecidas dobras seguramente da $3 \mathrm{a}$. fase de dobramento neste setor 1. Portanto, as dobras da $2 \mathrm{a}$. fase apresentariam ondulações nos seus flancos, com orientação da foliação variando aproximadamente entre N60E a N45W, com mergulhos respectivamente para NW e NE.

Pelo exame do mapa 1itológico-estrutural, nota- se ainda, que o Setor 1 encontra-se representado por um grande nūme ro de pequenos blocos tectônicos apresentando leve rotação e pos sivelmente com basculamentos. Desta forma, a atitude da foliação deve variar de bloco para bloco, de acordo com o grau de movimen tação, sendo em grande parte responsāvel pela variação geral ex 



Figura 13 - Diagramas de contorno de pólos das normais (obtidos na rede Schmidt-Lambert,
Hemisfério Inferior) a Foliações dos Setores 1 e 2. 

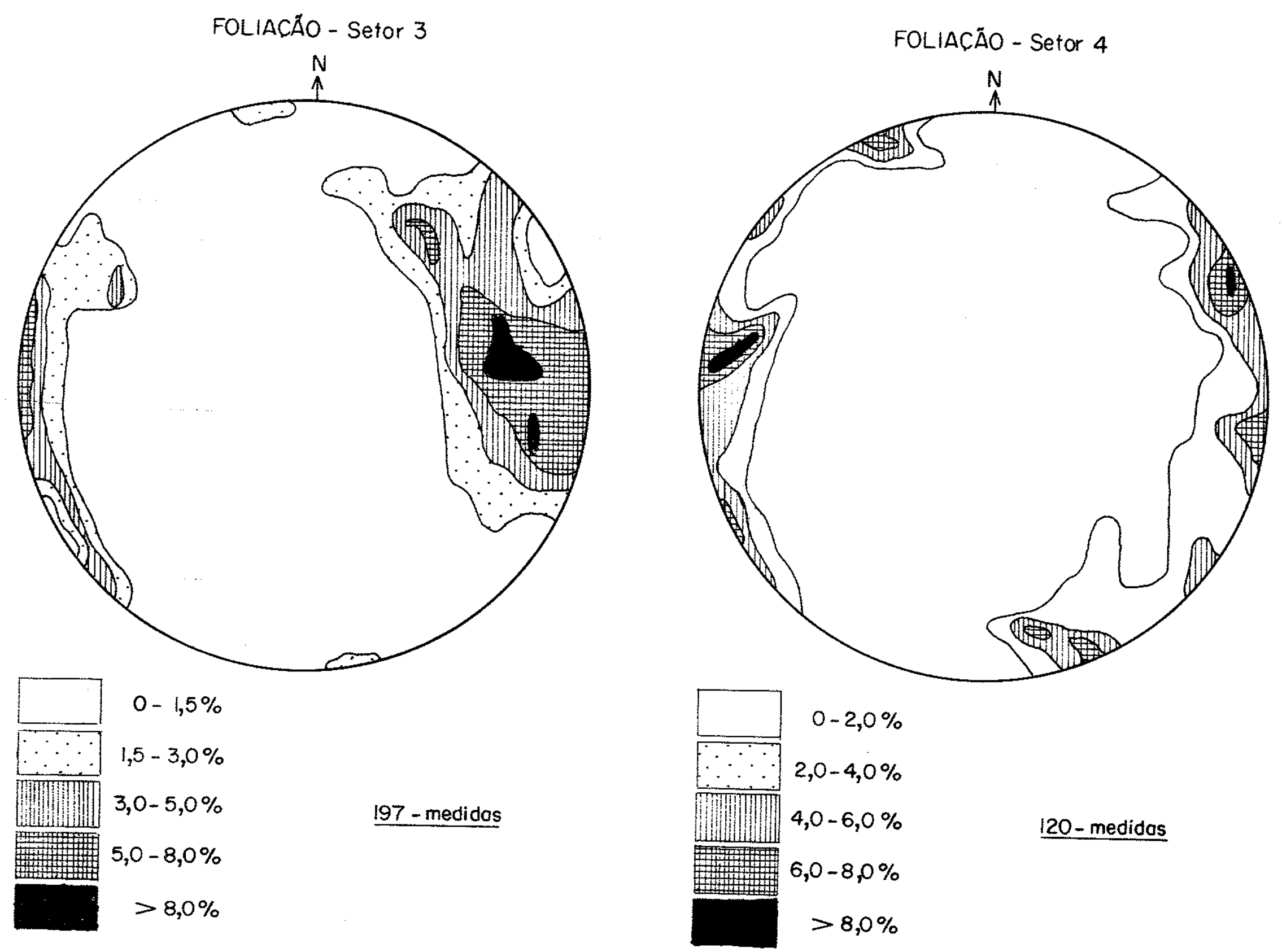

Figura 14 - Diagramas de contorno de pólos das normais (obtidos na rede Schmidt-Lambert,
Hemisfério Inferior) a Foliações dos Setores 3 e 4 . 


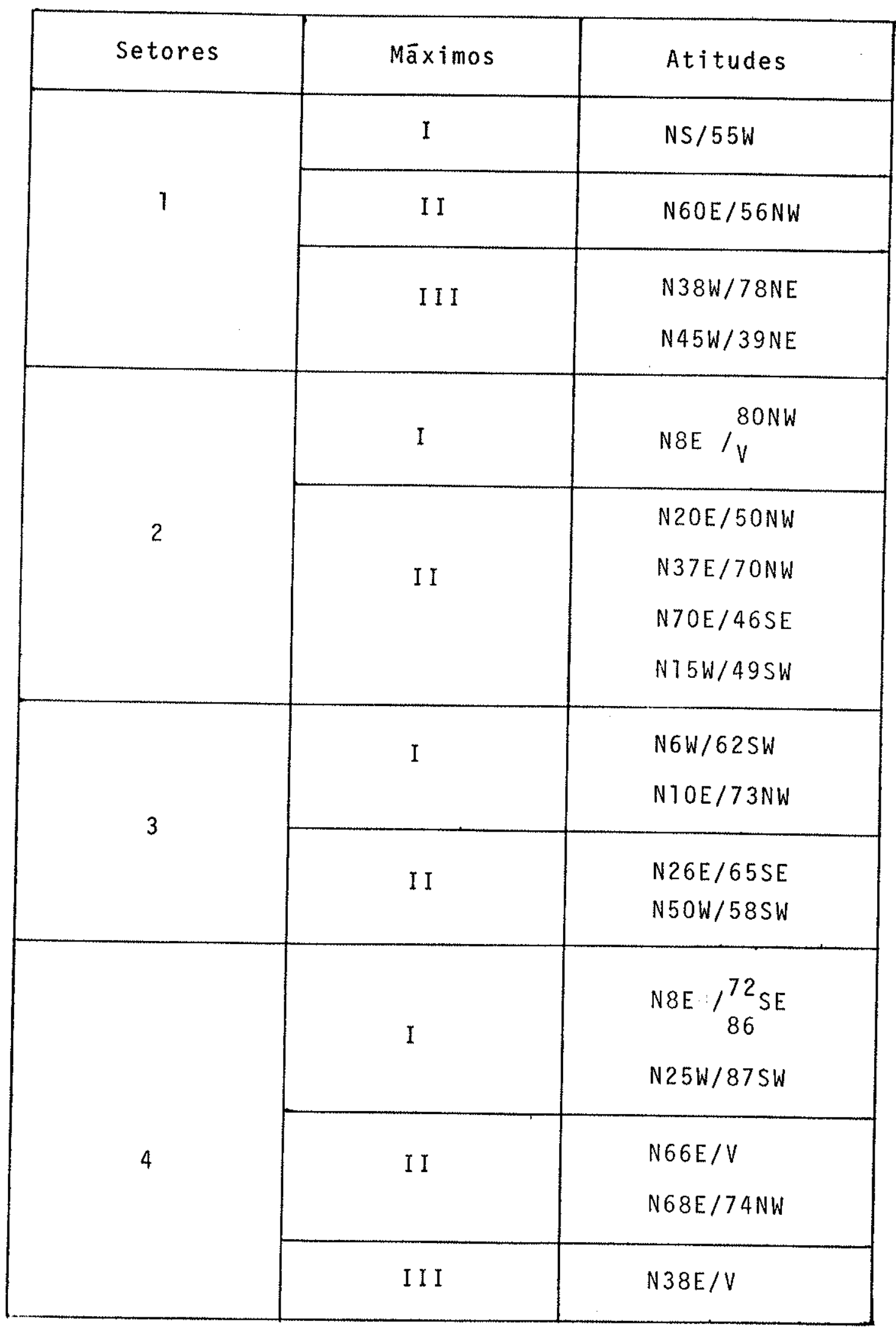

Tabela 4 - Máximos em ordem de frequẽncia obtidos a partir dos diagramas de contorno das figuras 13 e 14 para atitudes de foliação dos setores $1,2,3$ e 4 dos Arredores de Itapira - SP. 
bida pelos māximos. Assim, o estudo estatīstico para a variação da atitude da foliação relacionada às fases de dobramento, deve ser efetuado em blocos (dominios) individuais.

0 estereograma do Setor 2 , visto como um todo, reflete de imediato, o "nariz" da estrutura sinforme a leste de Itapira. O māximo 1, com a foliação mostrando atitude N8E/Subv., refere-se provavelmente à orientação preferencial da foliação plano axial desenvolvida na $2 a$. fase de dobramento, bem como aos flancos das dobras da $4 a$. fase que seriam coaxiais em relação à 2a. fase.0 māximo II, com as seguintes orientações da foliação: N20E, N37E, N70E e N15W, resultando uma quirlanda completa, indi cam o redobramento da foliação plano axial da $2 a$. fase em torno do eixo da 4a.fase de dobramento. A 3a. fase de dobramento, que pode ser verificada na parte sudoeste do Setor 2 , no flanco direito da estrutura sinforme de Itapira, não ē percebida no estereograma, por apresentar seus flancos com orientação praticamente N-S, e pela superposição da 4 a. fase de dobramento bastante intensa no referido Setor.

As concentrações de pólos no estereograma do setor 3, não mostram tendēncia à distribuição em guirlanda. Os māximos I, com atitudes de foliação N10E/73NW e N6W/62SW, indicam, para a mesma, uma orientação mëdia N-S, e os mäximos II, com atitudes N26E/65SE e N50W/58SW, refletem variações para NNE-SSW e para NW-SE, respectivamente. A ausēncia de um ponto māximo bem defini do e a impossibilidade de se obter qualquer tipo de guirlanda com pleta, são caracterĩsticas de äreas com dobramentos superpostos. Nestas, a foliação originada em uma fase de dobramento, sofre ro tação ao longo de cada eixo das dobras superpostas (na ārea em questão são reconhecidas pelo menos trēs fases de dobramentos su cessivos), ocasionando uma dispersão dos valores que se traduz, no diagrama, por uma impossibilidade de se relacionar a orientação da foliação à uma dada faseide dobramento. Ainda, observando se $o$ intenso fraturamento apresentado no mapa litológico-estrutü ral anexo (ou na Figura 12), percebe-se que a acentuada variação na atual atitude da foliação no setor 3 é, em grande parte, resultante do rotacionamento e basculamento dos blocos por falhamentos.

O diagrama de pólos de superfícies 5 do Setor 4, na parte norte da ārea, apresenta à semelhança do anterior, uma dis 
persão dos valores,originando uma sērie de māximos. Assim, as concentrações de pólos apresentam os mäximos I com N8E/Subv. e N25W/Subv., māximos II com N66E/V e N68E/74NW, e māximo III com N38E/V. Com exceção do mäximo I, cuja orientação da foìação N25W representa em verdade a parte sudeste do Setor 4 (Figura 12), todos os demais mäximos apresentam como orientação da foliação o quadrante NE. A grande variação da orientação da folia ção, preferencialmente dentro do quadrante NE, sem a definição de um ünico mäximo, impossibilita a correlação com qualquer fase de dobramento. Observando-se a Figura 12, nota-se no setor 4 uma sërie de falhas com direção geral NE-SW, inclusive a unidade MC (milonitos e/ou cataclasitos) no extremo norte, constituindo parcialmente a zona de transcorrência de Jacutinga com foliação milonĩtico-cataclāstica tambëm orientada para NE. Assim, a foliação gnäissica acima referida, adquire essa orientação NE-SW em toda porção noroeste do setor 4 , pelo deslocamento e consequente rotação dos blocos tectónicos ao longo dos planos de deslizamento que produzem a zona de falhamento de Jacutinga.

Levando-se em consideração que o rejeito total ao longo do falhamento de Jacutinga deva ultrapassar a casa dos $100 \mathrm{~km}$ (Rodrigues, 1976; p.33), torna-se possivel imaginar a sua influēncia nas rochas adjacentes. Alēm disso, a foliação com orientação NW, na parte sudeste do Setor 4, que se inflete para NE à medida que se aproxima da falha de Jacutinga, a noroeste do referido setor, $\bar{e}$ bastante nitida, deixando claro que sua atual orientação è uma influēncia direta dos falhamentos.

Portanto, a ārea mapeada, que à primeira vista apresenta uma foliação com direção global N-S e mergulhos elevados, normalmente superiores a 500 , revela quando examinada por partes, uma considerāvel variação na sua orientação. Este fenōmeno ē devido não somente à reorientação causada pelas fases de dobramentos superpostos, mas, em grande parte, à influência dos falhamentos. Assim, pelo deslocamento e rotação dos blocos, a foliação com orientação NW-SE no extremo sudeste da ārea, apresenta tendências a adquirir reorientação $N-S$, à medida que se caminha tanto para oeste como para norte, com consequente e acentuada inflexão para $N E$ nas proximidades da zona de falhamento de Jacutinga, a noroeste da ārea. 


\section{Juntas}

Os diagramas estruturais correspondentes às juntas foram tambēm elaborados individualmente para cada setor, conforme subdivisão apresentada na Figura 12. Os diagramas de contorno estão representados nas Figura 15 e 16 , com os diferentes māximos deduzidos, contidos na Tabela 5 .

os mäximos obtidos para os diversos setores (Tabela 5), denotam a existēncia de um grande espalhamento de pontos, não configurando uma homogeneidade dos valores entre os diversos setores. Mesmo a nivel de setor, torna-se dificil correlacionar os sistemas de juntas a uma estrutura definida. Considerando- se que a ärea apresenta pelo menos três fases de dobramento sucessi vos, a orientação dos sistemas de juntas relacionados às dobras, pode variar de um setor para outro de acordo com a major intens dade local de uma ou mais fases de dobramentos.

No caso do Setor 2 , onde o maior nümero de medidas de juntas foi efetuado exatamente na estrutura sinformal de Itapira, originada na ültima fase de dobramento, parece haver uma ligeira correspondência entre a referida estrutura e os sistemas de juntas. Neste caso, a estrutura apresentando traço axial com orientação aproximada de N45E, mostraria o seguinte conjunto de juntas: o sistema subvertical N45E correspondendo a juntas do ti po longitudina 1; o N65W à transversal, e os EW e N5E às diagonais (Loczy e Ladeira, 1976, p. 77). Tambēm estão presentes neste setor, dois sistemas com mergulhos relativamente baixos,N28W/ $17 \mathrm{SW}$ e N83E/35SE, não paralelos ao plano axial da referida estru tura. Portanto, segundo Bagdley (1959; Fig. 286) estes não estariam aparentemente relacionados à estrutura.

Alēm das fases de dobramentos, com seus proväveis conjuntos individuais de juntas, ocorre tambēm o fraturamento re sultante dos sistemas de falhamentos. A consequente movimentação dos blocos provocada pelas falhas, seja atravēs de rotação ou deslocamento na vertical, permite um maior entendimento do carä ter dispersivo na orientação dos sistemas de juntas. Isto ocorre praticamente em todos os setores, em especial no setor 4 , e $\bar{e}$ muitas vezes perceptível mesmo no mapa litolögico-estrutural ane xo. 



Figura 15 - Diagramas de contorno de pólos das normais (obtidos na rede Schmidt-Lambert,
Hemisfério Inferios) a Juntas dos Setores 

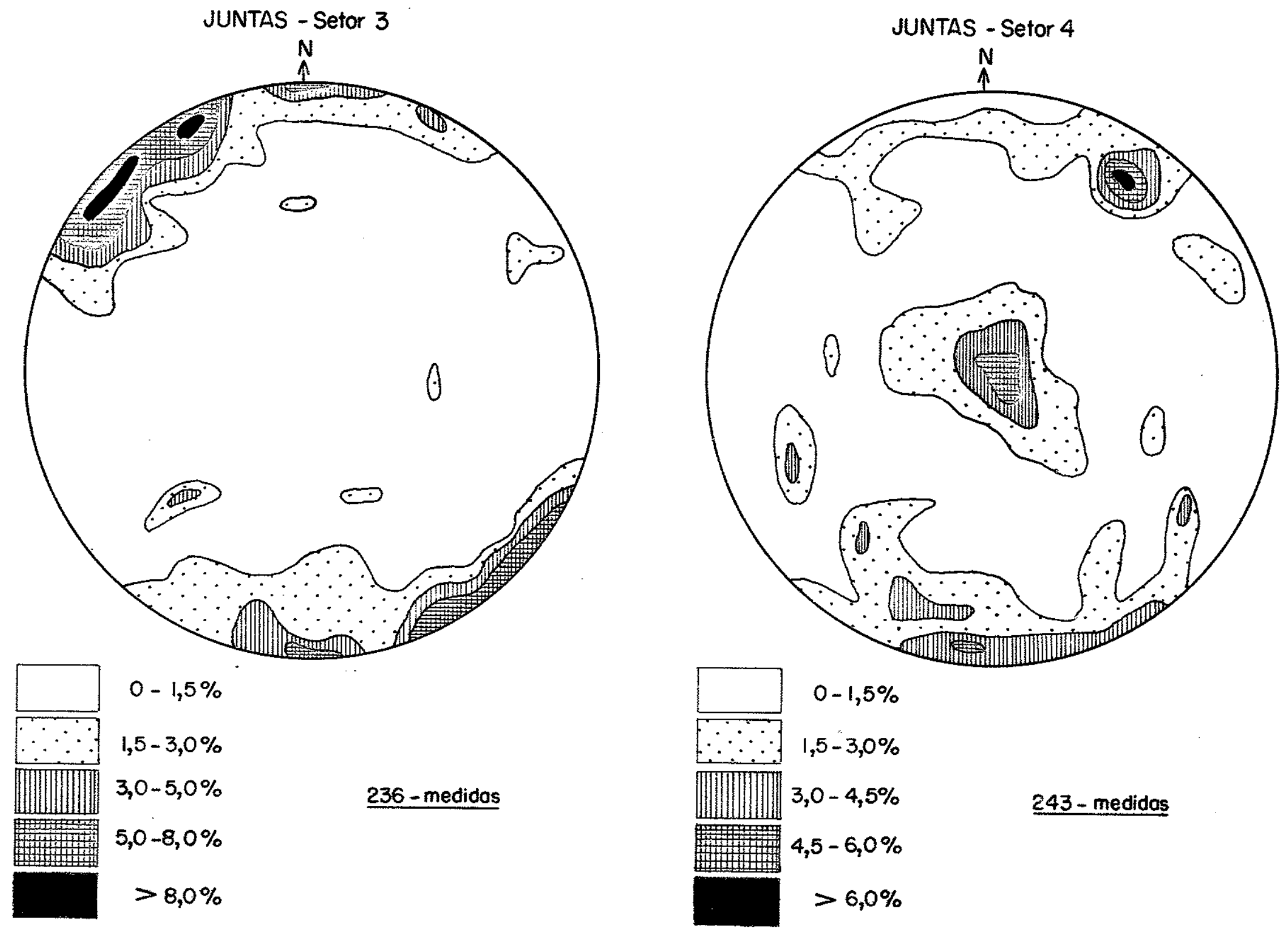

Figura 16 - Diagramas de contorno de pólos das normais (obtidos na rede de Schmidt-Lambert, Hemisfërio Inferior) a Juntas dos Setores 3 e 4. 


\begin{tabular}{|c|c|c|}
\hline Setores & Māximos & Atitudes \\
\hline \multirow{3}{*}{1} & I & $N 72 E / V$ \\
\hline & I I & $\begin{array}{l}\text { N15E/86SW } \\
\text { N80W/73NE } \\
N 75 W / 83 S W\end{array}$ \\
\hline & I I I & $\begin{array}{l}\text { N45E/22NW } \\
\text { N30E/71SE }\end{array}$ \\
\hline \multirow[b]{3}{*}{2} & I & $E W / V$ \\
\hline & I I & N45E/86SE \\
\hline & I I I & $\begin{array}{l}\text { N5E/87SE } \\
\text { N65W/84SW } \\
\text { N28W/ } 17 S W \\
N 83 E / 35 S E\end{array}$ \\
\hline \multirow{3}{*}{3} & I & $\begin{array}{l}N 63 E / 85 S E \\
N 42 E / 85 S E\end{array}$ \\
\hline & I I & $E W / V$ \\
\hline & I I I & $\begin{array}{l}N 64 W / 86 S W \\
N 46 W / 86 N E\end{array}$ \\
\hline \multirow{3}{*}{4} & I & $\mathrm{N} 56 \mathrm{~W} / 72 \mathrm{SW}$ \\
\hline & I I & $\begin{array}{l}\text { N18W/4SW } \\
N 85 W / 85 N E\end{array}$ \\
\hline & I I I & $\begin{array}{l}\text { N34E/72NW } \\
N 70 W / 75 N E \\
N 52 W / 63 N E \\
N 24 W / 66 N E\end{array}$ \\
\hline
\end{tabular}

Tabela 5 - Máximos em ordem de frequência obtidos a partir dos diagramas de contorno das figuras 15 e 16 para as at tudes de juntas dos setores $1,2,3$ e 4 dos arredores de Itapira -SP. 
0 levantamento estatistico dos sistemas de juntas permite mostrar que existe apenas um grande espalhamento, bem como, uma heterogeneidade na orientação das juntas na ārea abordada. Desta forma, o estudo em conjunto dos sistemas de juntas, ora efetuado, não permite tecer maiores considerações sobre a histöria da tectönica que afetou a região. Para tanto, demandariam trabalhos adicionais no sentido de se estudar os sistemas de juntas que ocorrem associados à cada estrutura especifica, co mo por exemplo, para cada fase de dobramento e para cada fase da tectōnica rüptil.

\section{Falhas}

As informações estruturais obtidas tanto atravēs da interpretação fotogeolögica quanto das observações de campo, demonstraram que a região $\vec{e}$ dominada não s $\vec{o}$ por falhamentos apro ximadamente retilineos e de grande extensão linear, como tambëm por falhas secundārias associadas e fraturas mais jovens.

o canto noroeste da ärea inclui pequeno trecho da gigantesca zona de Transcorrēncia de Jacutinga, que segundo Ebert (1968, pg.222), estende-se comprovadamente de Itapira (SP) atē Ipuiuna (MG) e, provavelmente, atē São Gonçalo (MG). Parte da zona de Falhamento de Jacutinga, correspondendo à continuação norte da ärea ora mapeada, encontra-se detalhadamente descrita em Rodrigues (1976). Trata-se de uma zona de cisalhamento que en globa värias falhas paralelas, com disposição geral segundo a di reção N60E e os valores de mergulhos dos planos de foliação, em milonitos, variando entre 75 a 909 , preferencialmente para NW.0s planos de fricção apresentam grande desenvolvimento de milonitos, ultramilonitos, alēm de cataclasitos, ultrapassando muitas vezes a $3 \mathrm{~km}$ de espessura. As estrias de atrito e dobras de arrasto, alëm de serem relativamente escassas no trecho correspondente, não se apresentam suficientemente claras, variando muito de atitude. Acreditamos sejam necessärios estudos adicionais, in clusive fora da ārea estudada, para a referida definição destas estruturas. 0 fato das estrias serem variāveis ē passível de explicação, pois, num falhamento de grandes proporções como o de Jacutinga, não são raros os deslocamentos relativos locais inclu sive com sentidos inversos ao do movimento geral. A pequena ex- 
tensão do referido falhamento, englobado pela ärea estudada, não permite fazer considerações sobre o valor do deslocamento. Contu do, Rodrigues $(1976, \mathrm{pg} .33)$ acredita que o rejeito total deva u 1
trapassar os $100 \mathrm{~km}$.

No limite oeste da ārea, imediatamente ao. norte das rochas Sedimentares da Bacia do Parană, faz-se presente uma faixa de granitōides cataclasados e intensamente intemperizados. Aparentemente, sua espessura ultrapassa a $2 \mathrm{~km}$. A leste apresenta-se encoberta pelos sedimentos do Rio do Peixe, e a sudeste, in terrompida por uma falha com disposição NE-SW. A ocorrência que é representada exclusivamente por blocos de dimensões variäveis, normalmente inferiores a $1,0 \mathrm{~m}$ de diämetro, revela, pela interpre tação fotogeolögica, alinhamentos estruturais que estariam dispostos perpendicularmente às estruturas do Falhamento de Jacutin ga. Ainda a tītulo de confirmação, em uma räpida caminhada reali zada por nōs mais ao norte, tivemos a impressão de que esta faixa de cataclasitos é interrompida pelo falhamento de Jacutinga.

Merece tambëm destacar a presença de alinhamentos estruturais, orientados principalmente segundo o quadrante $N E$ e que cortam as estruturas presentes na referida faixa de cataclasitos. Esses alinhamentos estruturais representariam o desenvolvimento de falhas mais jovens, que estariam sobrepostas às geradoras das texturas cataclästicas nos granitōides. Da mesma forma, nestes granitöides cataclasados, as variações na orientação das linhas de forma estrutural, deduzidas da fotointerpretação, sugerem rotação de blocos e reforçam a hipötese de duas fases ge radoras de falhas.

As demais falhas que retalham toda a extensão da ärea abordada, embora com grandes variações na orientação, revelam, pelo diagrama de contorno da Figura 17 englobando todos os setores (Figura 12), três conjuntos principais de orientação, con forme segue:

1. N65E/V

2. N30E/85SE

3. $N 57 W / 88 S W$

Assim, o conjunto com orientação $N 65 E / V$ deve estar relacionado ao sistema de falhamento de Jacutinga, e correspon- 
PLANOS DE FALHA E FOLIACÄO EM MILONITOS (todos os setores)

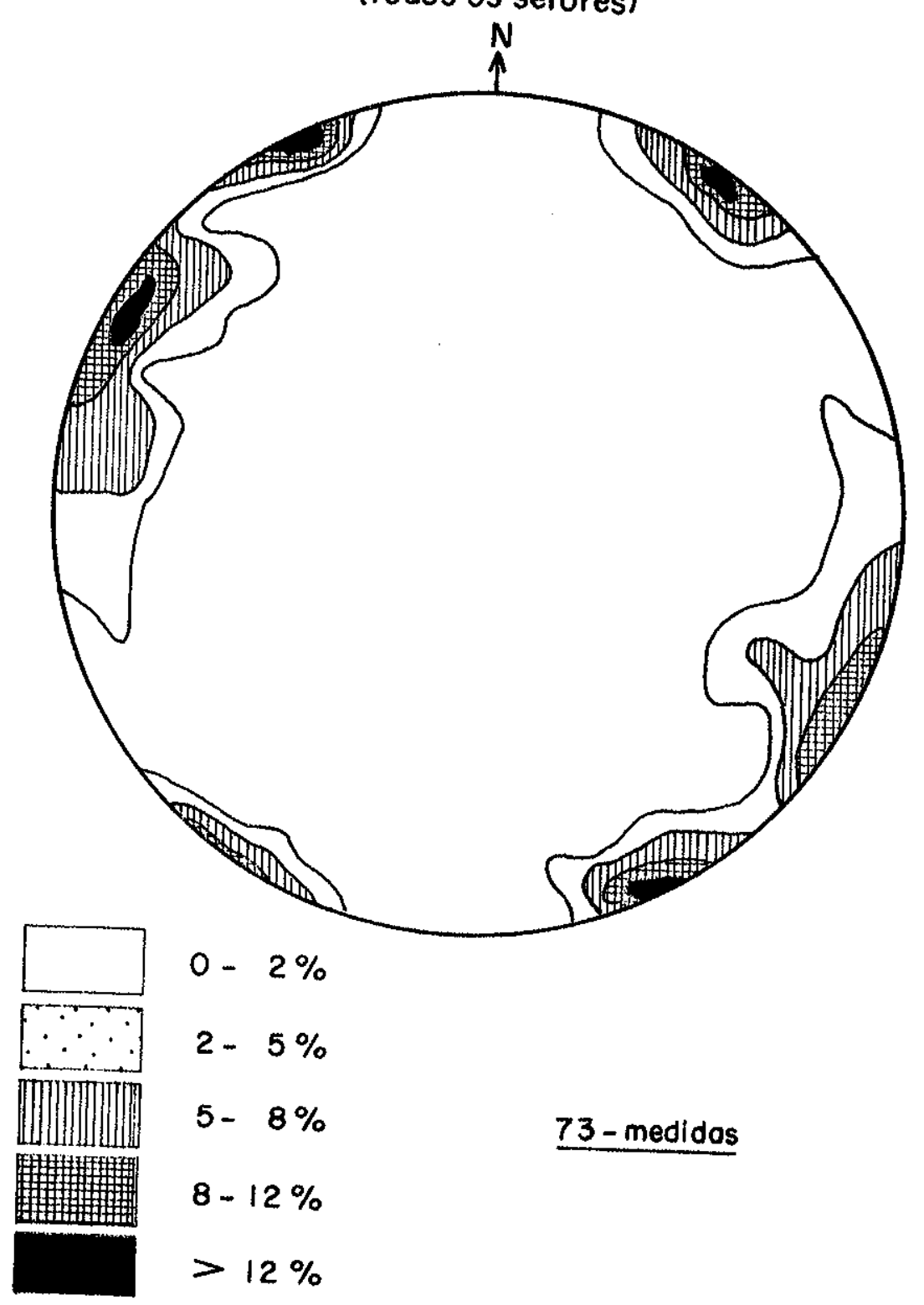

Figura 17 - Diagrama de contorno de pōlos das normais (obtidos na rede Schmidt-Lambert, Hemisfërio Inferior) aos Planos de Falhas e Planos de Foliação em milonitos, de todos os setores. 
dente ao cisalhamento primärio. 0 conjunto com orientação .N30E/ 85SE, deve representar falhas de cisalhamento de segunda ordem, tambēm de grande extensão linear, e que formam um āngulo da ordem de 350 com os planos das falhas principais.

Falhas de empurrão associadas a estas falhas, não foram bem definidas na ärea. Contudo, algumas feições como as linhas de forma estrutural ao norte da Fazenda Santa Rita, sugerem tratar-se de estruturas resultantes de falhas de empurrão as sociadas às falhas primärias. Ainda a nivel de afloramento, foi possivel constatar a presença de algumas falhas de empurrão na Rodovia Itapira-Jacutinga, um pouco ao sul da entrada para o vilarejo de Eleutērio. Estas exibem orientações muito variāveis, com planos de escorregamento sempre inferior a 450 , não permitin do qualquer correlaçäo com os dois conjuntos de falhas anteriores.

0 conjunto com orientação $N 57 W / 88$ SW, parece não estar relacionado ao falhamento de Jacutinga. Esta linha de pensamento reside no fato de que estes planos de falhas encontram se, muitas vezes interseccionados pelas falhas orientadas segundo o quadrante $N E$, como pode ser constatado no prōprio mapa lito lögico-estrutural anexo, e principalmente pela interrupção dos alinhamentos estruturais tão visĩveis em fotografias aēreas.Ainda, pela observação do mapa litolögico-estrutural, nota-se que os alinhamentos das falhas com orientação NW, sofrem uma infle$x$ ão para NE à medida que se aproximam da zona de falhamento de Jacutinga, sugerindo que esta ültima superpõe-se às primeiras.

As considerações acima, mais as observações acerca dos granitöides cataclasados, parecem realmente indicar a presen ça de duas fases distintas de tectōnica rígida para a ärea. Assim, as falhas orientadas segundo o quadrante $N E$ e associadas ao falhamento de Jacutinga, teriam sido originadas no final do Ciclo Brasiliano, conforme Rodrigues (1976, pg.37), e as falhas com orientação NW seriam mais antigas, podendo atë pertencerem a um Ciclo Prē-Brasiliano. No entanto, estas consideraçōes ... merecem, obviamente, estudos adicionais para futuras conclusões. Durante o desenvolvimento dos conjuntos de falhas do Ciclo Brasiliano, teriam ocorrido abatimentos de blocos com a consequente formação de fossas tectōnicas locais, responsāveis pela preserva ção dos sedimentos molässicos Brasilianos, como o caso da Forma- 
ção Eleutërio.

Em grande nümero de falhas, incluindo os três conjuntos mencionados, foi constatada a presença de faixas miloniti cas de espessuras variäveis, desde sub-centimëtricas a algumas dezenas de metros. Entre as estrias de atrito, nem sempre observadas, predominam as subhorizontais com inclinação mäxima ao redor de 250. As estrias subverticais, aparentemente muito mais ra ras, ocorrem normalmente afetando as subhorizontais.

A coexistēncia, em vārios planos de falhas, de estrias subhorizontais e subverticais, foi interpretada como sen do devida a uma reativação tectônica. Tambēm a presença de faThas nos sedimentos permo-carbonifferos, indica reativação tectonica das principais direções estruturais no decorrer dos tempos geolögicos. Essa reativação, tambëm descrita por Wernick (1972a) para a região de Amparo, foi considerada pelo mesmo autor como sendo equivalente à tectónica moderna ou neo-cenozōica, de carāter eminentemente epirogenëtico.

A inflexão para NE, das falhas com disposição inicial NW, tendendo atingir o paralelismo com a zona de falhamento de Jacutinga, permite sugerir para as rochas do Bloco Jundiai,na ärea, um deslocamento no sentido $S W$, qualificando o Falhamento Transcorrente de Jacutinga como sendo de carāter dextrōgiro.

\section{Veios de Quartzo e Pegmatitos}

$\mathrm{Na}$ ārea estudada ocorrem, fundamentalmente, veios de quartzo e, subordinadamente, pegmatitos compostos essencialmente por quartzo e microclinio. Entre eles predominam os de espessuras centimētricas e muito raramente os submētricos, sendo constatado um único caso na rodovia Itapira-Lindōia, pröximo ao $\mathrm{km} 34$, de um vejo de quartzo que atinge cerca de $5 \mathrm{~m}$ de espessu-
$\mathrm{ra}$.

Observando-se o diagrama de contorno de pólos na Figura 18, elaborado a partir de 78 medidas de veios de quartzo e de pegmatitos de toda a ārea, nota-se que ocorre uma dispersão dos pontos principalmente ao longo de quase toda a extensão do círculo mäximo. Portanto, os mergulhos são preferencialmente altos, acima de 700. A grande dispersão dos polos reflete o intenso fraturamento que se desenvolveu durante as diversas fases de 


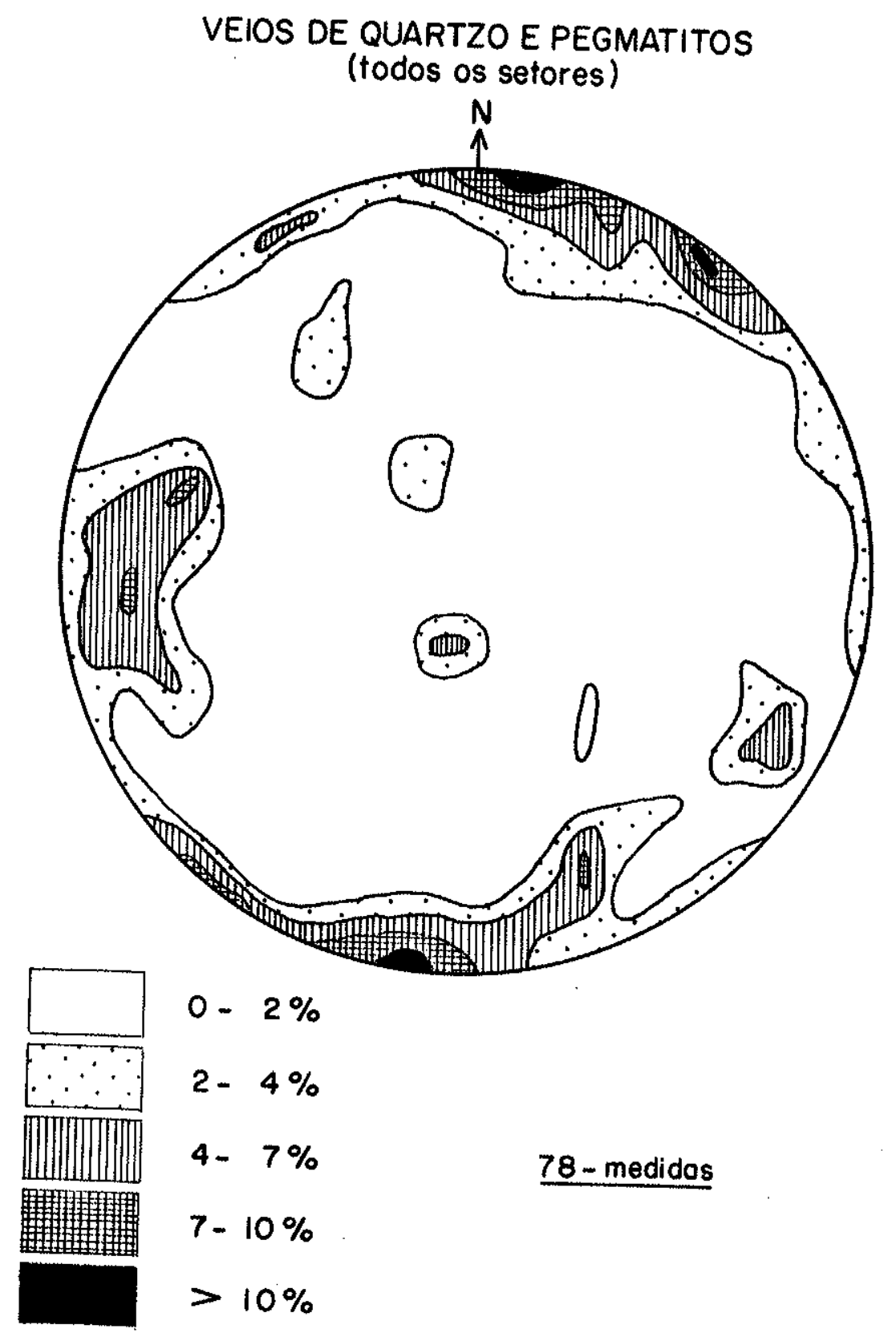

Figura 18 - Diagrama de contorno de pōtos das normais lobtidos na rede Schmidt-Lambert, Hemisfé rio Inferior) a Veios de Quartzo e Pegmatitos de todos os Setores. 
deformação que afetaram a região.

Em ordem de frequência, foram assinaladas, atravēs do diagrama, as seguintes concentrações principais de veios de quartzo e pegmatitos:

$$
\begin{aligned}
& \text { mäximos I }\left\{\begin{array}{l}
N 54 W / 87 S W \\
N 85 W / V
\end{array}\right. \\
& \text { mäximos II }\left\{\begin{array}{l}
N 15 E / 62 S E \\
N 67 E / 70 N W \\
N 5 W / 72 N E
\end{array}\right. \\
& \text { mäximos II }\left\{\begin{array}{l}
N 28 E / 78 N W \\
N 60 E / 86 S E \\
N 72 W / 76 N E
\end{array}\right.
\end{aligned}
$$

Tendo-se em vista o elevado indice de fraturamento da região e o lançamento das medidas de toda a ārea em um ünico diagrama, alēm do pequeno nümero destas medidas, torna-se djf cil fazer qualquer correlação entre a orientação dos veios de quartzo e pegmatitos com os tipos de fraturas. Pode-se dizer ape nas que foi constatada, no campo, a presença de uma sërie de veios de quartzo orientados paralelamente à foliação metamōrfica das rochas.

0 exame dos veios de quartzo revelou que os mesmos podem ser atribuídos a mais de uma geração. Assim, pode, ser notados veios cortando outros prē-existentes, fato este tambēm observado por Wernick e Penalva (1980, p.9) para as rochas do Grupo Pinhal e respectivas encaixantes. Estes podem ou não estar de formados, sendo o primeiro caso bastante raro. No caso de ambos os veios não exibirem deformações, tudo indica que sejam isöcronos sob o aspecto geológico. Por outro lado, quando uma das gera ções de vejos mostrar-se dobrada e o interceptante não, deve- se admitir certo lapso de tempo entre a formação de ambos os : corpos. Os veios dobrados indicam idade concomitante ou anterior a uma das fases de dobramentos que afetaram a ārea, enquanto que os não deformados são posteriores à ūitima fase de dobramento que teria ocorrido no Ciclo Brasiliano. Entretanto, não ē possível determinar o lapso de tempo que separa as gēneses destes veios. 


\section{DADOS GEOCRONOLOGICOS}

Do conjunto de amostras disponiveis, foram selecio nadas as mais adequadas para o estudo geocronológico, desenvolvi do mediante emprego dos métodos K-Ar e Rb-Sr. Os dados analiticos completos (10 determinações pelo mētodo K-Ar, e 36 pelo mëto do $\mathrm{Rb}-\mathrm{Sr}$ ) encontram-se respectivamente na Tabela 6 e Apêndice 1. o posicionamento geogräfico das amostras pode ser observado no mapa de localização dos afloramentos em anexo.

Para o mētodo Rb-Sr, as anālises foram executadas unicamente em rocha total, e as discussões geocronolögicas foram feitas mediante emprego de gráficos isocrônicos $\mathrm{Rb}^{87} / \mathrm{Sr}^{86}$ versus $\mathrm{Sr}^{87} / \mathrm{sr}^{86}$ de alto valor interpretativo. Cabe aqui lembrar que 0 emprego destes diagramas permite a obtenção de resultados coeren tes em termos de evolução geológica sofrida pelo material. Mesmo em rochas policiclicas, ē sabido que os isōtopos do estrôncio po dem se redistribuir durante os eventos mais novos, sem haver abertura do sistema. Portanto, anălises em amostras representativas da rocha total podem revelar, em condições ideais, inclusive a época da primeira cristalização, o que seria dificilmente obtido por anālises Rb-Sr em minerais separados ou anălises apa rentes K-Ar. As idades convencionais Rb-Sr (trata-se de idades isoladas nas quais se assume uma relação isotōpica inicial para - sistema), embora constem do Apêndice 1, praticamente não foram utilizadas neste capitulo, devido ao seu menor valor inter pretativo.

As anälises K-Ar foram efetuadas em minerais separados, preferencialmente micas e anfibólios que são conhecidos pelas propriedades favorāveis à retenção de argônio. Estas data ções devem ser encaradas como valores minnimos referentes à época do resfriamento regional e consequente fechamento do reticulo cristalino do mineral.

Desse modo, as determinações K-Ar teriam como prin cipal finalidade determinar a ocorrência do ūltimo evento termotectônico que teria ocorrido na região. Por outro lado, as deter minações Rb-Sr em rocha total teriam por objetivo situar no tempo os eventos de homogeneização isotōpica de Sr, ligados muitas vezes a prōpria formação das rochas.

os dados radiométricos fornecidos pelos métodos 
$\mathrm{K}-\mathrm{Ar}$ e Rb-Sr para as rochas da ārea mapeada, mostraram boa coerência com o padrão geocronolögico regional prë-existente (capitulo II), e indicam, para a ārea de Itapira, uma evolução comple xa e policiclica.

A seguir, os dados radiomētricos são comentados vi sando a caracterização dos provāveis ciclos geotectónicos, ou, em parte, tecto-termais, que teriam ocorrido na região.

VII. 1. Discussão dos dados radiomëtricos $K-A r$

Como pode ser visto pela Tabera 6 , com exceção da amostra 14, todas as demais apresentam idades aparentes características de eventos do Ciclo Orogenëtico Brasiliano, entre 534 e $700 \mathrm{m.a.}$, demonstrando a importãncia deste na evolução geológica regional.

Pelo menos uma rocha, o anfibolito do afloramento 14, apresenta idade K-Ar claramente prë-Brasiliana, demonstrando desde jā a existência de rochas regionais formadas em épocas anteriores. Acresce que, tratando-se de determinação K-Ar, representa apenas a idade aparente mĩnima da rocha, não sendo possível relacionă-la com o evento formador.

As idades K-Ar em hornblenda dos anfibolitos 43 e 18, respectivamente $\operatorname{com} 623 \pm 10$ e $671 \pm 8 \mathrm{~m} . \mathrm{a}$. , são semelhantes aos valores obtidos por Cordani e Bittencourt (1967) pelo mesmo mëtodo radiomëtrico para anfibolitos da região de Arcadas e Amparo. Idades pouco superiores pelo mëtodo Rb-Sr $(690 \pm 20 \mathrm{~m}$. a.) obtidas por Wernick et a1. (1976b) em rochas graniticas do Maciço Granitico de Morungaba, são encaradas pelos autores supra citados como correspondendo à principal fase do metamorfismo regional do Ciclo Orogēnico Brasiliano. Com base nas considerações acima, os anfibolitos 43 e 18 devem representar idades minimas da referida fase, apōs a mesma ter atingido resfriamento suficiente para o mineral reter o argōnio.

Curiosa è a idade de $700 \pm 8 \mathrm{~m} . \mathrm{a}$. apresentada pela muscovita da amostra 1 , que interpretamos como contemporānea à ēpoca de formação de granitos da fase sin-tectônica do Ciclo Bra siliano, conforme determinações $\mathrm{Rb}-\mathrm{Sr}$ apresentadas por Wernick et a1. (op.cit.) e Almeida et al. (1973). Esta idade pode tambëm 
Tabela 6 - Idades K-Ar de Rochas dos Arredores de Itapira - (SP)

\begin{tabular}{|c|c|c|c|c|c|c|c|}
\hline $\begin{array}{l}\text { Nọ de } \\
\text { Campo }\end{array}$ & $\begin{array}{l}\text { No de } \\
\text { Labor. }\end{array}$ & Rocha & Mineral & $\% \mathrm{~K}$ & $\begin{array}{c}\mathrm{Ar}^{40} \mathrm{rad} . \\
10^{-5} \text { ccSTP } / \mathrm{g}\end{array}$ & $\begin{array}{c}A r^{40} a t m . \\
(\%)\end{array}$ & $\begin{array}{l}\text { Idade } \\
(m \cdot a \cdot)\end{array}$ \\
\hline 1 & 3606 & Musc.Quartzito & Muscovita & 8,24 & 27,88 & 4,57 & $700 \pm 8$ \\
\hline 14 & 3600 & Anfibolito & Hornblenda & 0,74 & 4,44 & 1,46 & $1103 \pm 20$ \\
\hline 140 & 34.52 & Biot.Gn.Porfirobl. & Microclinnio & 3,40 & 8,44 & 11,77 & $539 \pm 27$ \\
\hline 18 & 3458 & Anfibolito & Hornblenda & 0,86 & 2,75 & 27,96 & $671 \pm 8$ \\
\hline $19 D$ & 3453 & Biotita Gnaisse & Biotita & 7,50 & 18,47 & 2,76 & $534 \pm 7$ \\
\hline $20 \mathrm{~A}$ & 3475 & Biotita Xisto & Biotita & 7,26 & 20,64 & 3,58 & $605 \pm 7$ \\
\hline 43 & 3599 & Anfibolito & Hornblenda & 0,39 & 1,14 & 9,22 & $623 \pm 10$ \\
\hline 100 & 3506 & Musc.Quartzito & Muscovita & 7,84 & 20,74 & 1,67 & $568 \pm 9$ \\
\hline $100 \mathrm{~A}$ & 3660 & Biotita Xisto & Biotita & 6,48 & 15,90 & 4,39 & $534 \pm 16$ \\
\hline 150 & 3476 & Musc.Quartzito & Muscovita & 8,46 & 22,33 & 3,59 & $568 \pm 20$ \\
\hline
\end{tabular}

Localidade das Amostras

1 - Pedreira, Km 49 da rodovia Mogi Mirim-Itapira

14 - Afloramento, $\mathrm{Km} 35,3$ da rodovia Itapira-Lindóia

14D - Afloramento, Km 35,3 da rodovia Itapira-Lindóia

18 - Pedreira à SE do cruzamento do Rio do Peixe com a rodovia Itapira-Jacutinga

$20 \mathrm{~A}$ - Afloramento, rodovia Itapira-Jacutinga cerca de 1 km após o Rio Eleutērio

43 - Afloramento, Km 34 Itapira-Jacutinga cerca de $700 \mathrm{~m}$ antes do Rio Eleutērio

rodovia Itapira-Lindóia

$100 \mathrm{~A}$ - Afloramento

150 - Afloramento, rodovia Itapira-jacutinga à $S$ da Fazenda da Fortaleza 
ser indicativa de uma rocha prē-Brasiliana, tendo a mica retido parcialmente seu argônio durante o pico termal da fase principal do metamorfismo regional, mantendo-se como sistema fechado em relação ao argōnio em fases posteriores de intensidade menor durante o Ciclo Brasiliano. Merece tambëm destacar o fato de que os muscovita quartzitos deste afloramento, apresentam lamelas de muscovita anormalmente desenvolvidas em relação aos demais afloramentos, com dimensões muitas vezes superiores a $1,0 \mathrm{~cm}$, o que, em verdade, tem grande influëncia na retenção do argönio.

As demais idades aparentes obtidas a partir das mi cas e de um microclīnio, ambos com poder de retentividade do argōnio menor que a hornblenda, são coerentemente mais jovens, devendo tambëm ser relacionados às fases ou episōdios termais da orogenia brasiliana.

E interessante observar que, pelo menos no: caso dos afloramentos 100 e 100A, fica demonstrada a melhor retentivi dade para o argōnio da muscovita em relação à biotita. Tal fenomeno pode tambëm explicar o fato do microclīnio 14D, ter apresen tado idade mais jovem que a maioria das biotitas. Como se sabe, a estrutura cristalina dos feldspatos favorece a difusão de argó
nio.

Admitindo-se que um ciclo orogenētico mais de um pico termal durante sua evolução,as idades apresenta reveladas pelos conjuntos de idades aparentes de $605 \pm 7$.m.a.,
$568 \pm 9 \mathrm{~m} . \mathrm{a}$. e $568 \pm 20 \mathrm{~m} . \mathrm{a}$. obtidas respectivamente das amostras $20 \mathrm{~A}, 100$ e 150 , e $534 \pm 7 \mathrm{~m}$.a., $534 \pm 16 \mathrm{~m} . \mathrm{a}$. e $539 \pm 27 \mathrm{~m}$. a. das amostras 190, $100 \mathrm{~A}$ e 14D, poderiam corresponder, com ressalvas, devido principalmente à falta de outras evidências e ao pequeno nümero de datações, a outros fluxos tērmicos que teriàm ocorrido durante a orogenia brasiliana. Desta forma, tais idades aparentes teriam uma relação com os fluxos tērmicos responsāveis pelas värias gerações de granitōides dos complexos polidiapiricos regionais (Wernick e Penalva, 1980).

A tentativa de correlacionar as idades obtidas pelo mëtodo K-Ar com diversas fases ou episödios orogenëticos durante o evento ocorrido no Ciclo Brasiliano, encontra apoio em vārios trabalhos realizados no sistema de Dobramento Ribeira e Zona Cristalina Norte de São Paulo.Cordani e Bittencourt (1967), 
Vandoros e Franco (1969), Cordani e Kawashita (1971), Hasui e Hama (1972), Cordani et a1. (1973, 1974), Wernick et a1. (1976b) e Wernick e Penalva (1978) indicam a formação de granitos sin-, tardi- e pōs-tectōnicos com idades mëdias em torno de 650,600 e $550 \mathrm{m.a}$., respectivamente. Ainda segundo Cordani e Kawashita (op. cit.), os granitos tardi-e pös-tectōnicos do Grupo Açungui, teriam seus magmas formados a partir do material do prōprio cintu rão orogênico, refletindo um aquecimento nestas ēpocas.

Assim as idades encontradas para os metamorfitos dos arredores de Itapira, aqui relacionadas às ëpocas de forma çäo dos granitos, devem representar as fases de aquecimento de caräter regional com intensidade cada vez menor do Ciclo Brasiliano.

Embora o nümero de determinações pelo mëtodo $K-A r$ seja bastante reduzido, os valores parecem indicar que a fase fi nal de levantamento epirogenëtico da cadeia montanhosa resultante do cinturão orogenētico na ārea, teria ocorrido cerca de 170 m.a. apōs a fase principal do metamorfismo regional do Ciclo Bra siliano, que seria de 700 a $530 \mathrm{~m}$.a. aproximadamente.

VII.2. Discussão dos dados radiomētricos $R b-S r$

Tendo em vista o caräter policīclico das rochas re gionais, exposto em capitulos anteriores; e em especial à suposi ção de Ebert (1971) de que o Grupo Itapira (segundo Ebert, estaria representado na ärea pela sequência metassedimentar composta pelos biotita xistos e quartzitos de composição variāvel) representaria, possivelmente, uma unidade mais jovem que o Grupo Amparo, resolveu-se tentar a realização de um bom nümero de anä1 ises $\mathrm{Rb}-\mathrm{Sr}$ em rocha total, que possuem maior valor interpretat vo.

A Figura 19 exibe a isōcrona obtida em amostras de biotita gnaisse porfiroblästico e gnaisse granitico de um mesmo afloramento (14), situado no $\mathrm{km} 35,3$ da rodovia Itapira-Lindóia. Também estā incluīda uma amostra do anfibolito 43 , distante cerca de $700 \mathrm{~m}$ do afloramento anterior no sentido de Lindöia. Nos cālculos para a obtenção da inclinação da isōcrona, não foram in cluídas as amostras 43 e 14B, devido ao fato da primeira pertencer a um afloramento diferente das demais e a segunda ocupar uma 




Figura 19 - Diagrama isocrōnico Rb/Sr do gnaisse granitico e do biotita gnaisse porfiroblastico
do afloramento 14 . 
posição anōmala na isōcrona. 0 bom alinhamento obtido, mesmo incluindo-se rochas diferentes, caracteriza uma importante homogeneização isotōpica ocorrida na ëpoca de $2085 \pm 88 \mathrm{m.a}$., que se deu provavelmente durante uma fase de feldspatização tardia do C clo Transamazônico. 0 mesmo gnaisse granitico que chega a apresen tar mais de $30 \%$ de microclīnio, o que não é normal para rochas do referido ciclo na região, reflete a intensa microcilinização local responsāvel pela homogeneização isotōpica.

A razão inicial $5 r^{87} / \mathrm{Sr}^{86}$ de $0,7033 \pm 0,0019$, pode ser considerada como confiävel, visto que os pontos analíticos es tão bem distribuĩdos no diagrama isocrōnico. Este valor relativamente baixo, sugere que a migração ionnica, responsāvel pela felds patização, teve origem profunda, em locais empobrecidos em rubidio.

Como as rochas ora datadas ocorrem intercaladas com os biotita xistos e os muscovita (biotita) quartzitos, com contatos não tectônicos e, em muitos casos, exibindo contatos gradacio nais indicativo de rochas pertencentes ã faixa do Grupo. Itapira de Ebert, torna-se sugestiva uma idade pelo menos correspondente ao Ciclo Transamazónico para o referido Grupo.

A posição anômala do ponto analitico 14B, melhor ví sualizado na Figura 20 onde se encontra ampliada parte da Figura 19 , indica uma idade aparente de $2505 \mathrm{~m}$. a. para a respectiva amostra, empregando-se a mesma razão inicial $\mathrm{sr}^{87} / \mathrm{sr}^{86}$ de 0,7033 . Tal amostra, que foi obtida no afloramento 14, trata-se de um biotita gnaisse porfiroblästico idēntico aos demais do mesmo afloramento. Para afastar a possibilidade de erro analïtico, esta anălise foi repetida, tendo sido confirmada a posição. Esta idade poderia indicar a existēncia de material anterior ao ciclo Transamazônico que, apesar de ter sido afetado por evento metamörfico dos mais intensos, de carāter catazonal, seguido de metassomatose potāssica, conseguiu manter parte de seu estrôncio radiogēnico original. Por outro lado, o mais provävel seria uma forte modificação no conteūdo de estrôncio, que teria sido concentrado pelo efeito da metassomatose tardia das rochas formadas no pröprio ciclo orogêni co Transamazönico. Contudo, tornam-se necessärios estudos geocronolögicos, estruturais e petrogräficos adicionais para maiores es clarecimentos.

0 anfibolito referente ao ponto analitico 43 , deve 


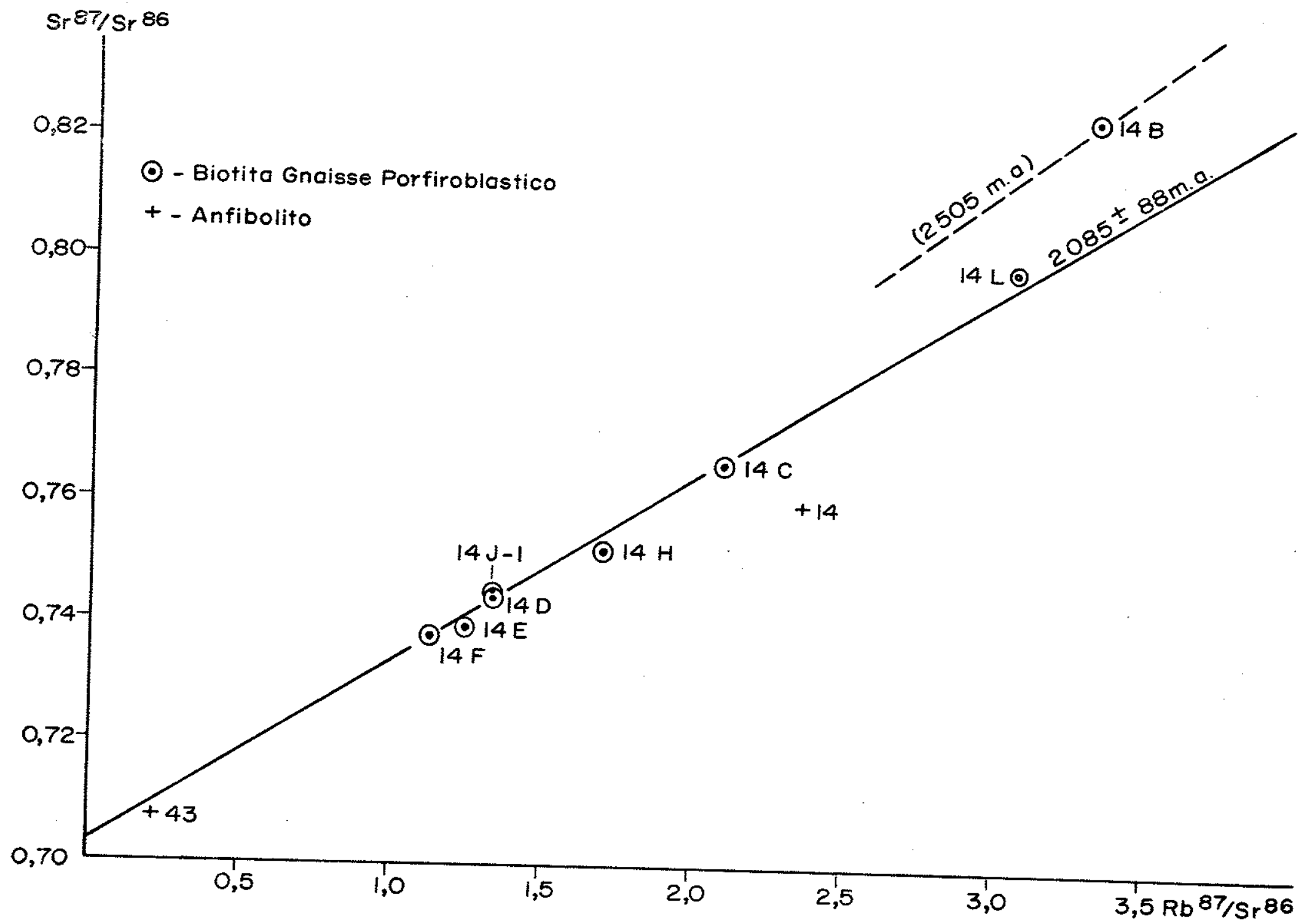

Figura 20 - Ampliação de parte do diagrama isocrōnico da Figura 19. 
corresponder, provavelmente, às manifestações do magmatismo bāsi co associado à evolução geossinclinal que resultou na orogenia transamazônica. Esta suposição estaria inteiramente de acordo com as considerações obtidas atravës das relações estruturais de campo e petrogräficas descritas nos capitulos IV e $V$.

A idade de $1918 \pm 72 \mathrm{~m} . \mathrm{a}$. apresentada pela isōcrona da Figura 2l, obtida a partir de amostras de biotita hornblen da gnaisse do tipo Amparo (afloramento 18), pode ser considerada como concordante com o valor obtido para a isōcrona da Figura 19, ou seja, correspondente ao Ciclo Transamazónico. A idade pouco inferior apresentada por estas amostras, deve estar relacionada a fenomenos de cataclase e cisalhamento, com parcial recrista lização sofrida pelas amostras. A amostra 18E, com seu ponto ana litico abaixo da isōcrona, mostra-se mais cataclasada e com razoāvel quantidade de minerais secundärios como clorita e epídoto, provocando rejuvenescimento.

Por outro lado, deparamos com a baixa relação $\mathrm{Rb}^{87}$; $\mathrm{Sr}^{86}$ do diagrama $(<2)$, o que de certa forma impossibilita enca rar o valor de $1918 \pm 72 \mathrm{~m}$. a. como definitivo, pois, amostras mais favorāveis poderão conduzir a uma modificação desse vălor.

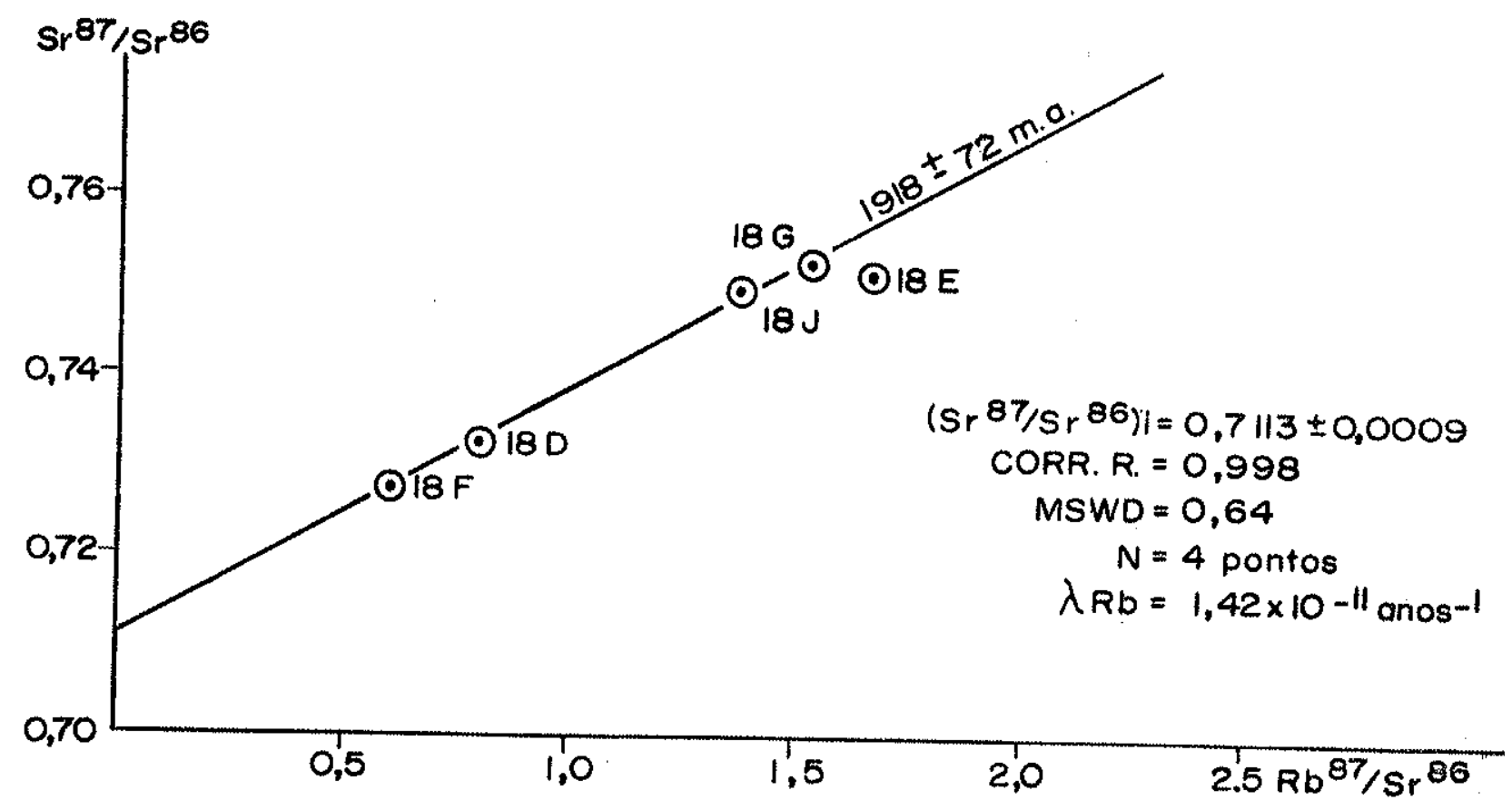

Figura 21 - Isōcrona Rb/Sr do gnaisse Amparo do afloramento 18. 
A isöcrona, da qual excluju-se o ponto analitico $18 \mathrm{E}$, definiu uma razão inicial $\mathrm{Sr}^{87} / \mathrm{Sr}^{86}$ de 0,7113 sugerindo que estas rochas sejam resultantes de material com vida crustal ante rior e retrabalhado durante o Transamazónico.

Idade semelhante às obtidas pelas duas isōcronas anteriores foi encontrada por Wernick et a1. (1976b) para rochas do Grupo Amparo na região de Socorro-Amparo. Desta forma, se a Figura 21 refere-se a rochas do Grupo Amparo, e a Figura 19 real mente à rochas do Grupo Itapira, ficaria demonstrado que estes dois Grupos são contemporâneos.

Por outro lado, as razões iniciais diferentes obti das nos dois diagramas, sugeriria materiais originais distintos para as rochas dos Grupos Amparo e Itapira.

A isöcrona da Figura 22 com idade de $2230 \pm 39 \mathrm{~m}$. a., foi obtida a partir de cinco amostras de biotita gnaisse de um mesmo afloramento localizado na rodovia Itapira-Jacutinga,cer ca de $1 \mathrm{~km}$ do Rio Eleutērio, no Estado de Minas Gerais. Este afloramento $\bar{e}$ composto por rochas de aspecto anatexitico, exibindo dobras irregulares com zona apical espessada e denotando origem dominantemente por fluxo num meio de elevada plasticidade. A idade apresentada pela isöcrona parece representar um rejuvenescimento isotópico parcial de rochas mais antigas durante o Ciclo Transamazōnico. Esta ūitima argumentação, pode ser encarada com certa credibilidade devido à sua razão inicial $\mathrm{sr}^{87} / \mathrm{sr}^{86}$ de $0,708 \pm 0,0007$, relativamente elevada. Esta razão inicial sugere que as rochas formaram-se a partir de material com vida crustal anterior, similarmente ao proposto na interpretação da isöcrona da Figura 21.

As suspeitas da presença de rochas referíveis ao embasamento do Grupo Amparo na região nordeste do Estado de São Pauto e sul de Minas Gerais, vêm crescendo com o desenvolvimento dos ūitimos trabalhos na região. Fiori et al. (1978), Fiori(1979), Wernick e Fiori (1979) e Wernick et al. (1979) estudando as regiões acima referidas, sugeriram, atravēs de relações estruturais e associação paragenëtica, a presença de rochas pertencen tes ao embasamento do Grupo Amparo. Estas rochas que . ocorrem principalmente no Complexo de Silvianōpolis, foram tambëm verifi cadas por Fiori (op.cit.), embora esparsamente, desde serrania $\underline{a}$ 




Figura 22 - Isōcrona Rb/Sr do biotita gnaisse do afloramento 19.

té Pouso Alegre, no extremo sui de Minas Gerais, situada cerca de $60 \mathrm{~km}$ a nordeste da ärea ora estudada.

Segundo o mesmo autor, as litologias e estruturas do Complexo de Silvianōpolis são muito semelhantes às do Grupo Barbacena, com idades entre 2800 e $2600 \mathrm{m.a}$. (Cordani et al. 1973), referentes ao Ciclo Orogênico Jequié. No mapa geológico do sul do Estado de Minas Gerais, organizado por Ebert (inēdito), - Complexo de Silvianópolis representa uma extensão de rochas de nominadas por aquele autor como pertencentes ao Grupo Barbacena.

Ainda conforme Fiori (informação verbal), o biotita gnaisse de aspecto anatexitico, ora datado, ē muito semelhan te aos gnaisses anatexiticos do Complexo de Silvianöpolis,o que nos conduz uma vez mais a suspeitar da presença de rochas do embasamento do Grupo Amparo na região de Itapira.

A Figura 23 exibe uma isōcrona obtida a partir de anälises de três amostras de biotita gnaisse do afloramento 22 e quatro de gnaisse granitico do afloramento 100 . Todas estas amos tras apresentam-se cisalhadas e com textura cataclästico-milonitica, alëm de intensa recristalização. As primeiras provēm da Pedreira Fortaleza, localizada na fazenda homōnima, onde ocorrem 
intercaladas com biotita xistos e mármores calcīticos. As ültimas situam-se cerca de $1,5 \mathrm{~km}$ a $S E$ da mesma fazenda e encontram- se intercaladas com muscovita quartzitos e biotita xistos. Da mesma forma que as amostras da Figura 19, estas litologias podem ser incluídas como pertencentes a faixa do Grupo Itapira.

A relativa dispersão dos pontos analîticos em relação ã isōcrona, pode, em parte, ser atribuïda ao fato das amostras pertencerem a mais de um afloramento, ou ainda, ao desequili brio isotópico devido a perturbações posteriores.

A idade de $1140 \pm 88 \mathrm{~m} . \mathrm{a}$. apresentada pela isōcrona, com razão inicial $\mathrm{Sr}^{87} / \mathrm{Sr}^{86}$ de $0,7343 \pm 0,0028$, indica que as rochas jā possuiam evolução crustal anterior à ēpoca da homogeneiza ção. Dados petrográficos não permitiram caracterizar as amostras integrantes da isōcrona como sendo cogenēticas a um evento intermediārio entre os Ciclos Transamazōnico e Brasiliano (Ciclo Uruaçuano"?",jā que são patentes sinais de recristalização e neoforma ção de minerais indicando longa histōria evolutiva metamörfica. Es tes dados e a localizaçäo das amostras, sugerem tratar-se mais de idades de rejuvenescimento, talvez vinculadas a fenômenos dinâmicos, do que a idades de formação.

Tentativamente, em Artur et a 1. (1979), essa idade foi correlacionada a um fluxo de calor que re-homogeneizou sistemas isotōpicos fechados no ciclo Transamazōnico, associado a uma tectōnica de ruptura (falhas, cisalhamento) que caracterizaria parte do Ciclo Uruaçuano. Esta interpretação toma algum impulso se considerarmos que acontecimentos geológicos crono- correlatos foram registrados em grande parte da crosta mundial, podendo ser citados entre outros, o Ciclo Tecto-magmātico Dalslandiano na Europa Oriental (Priem et al., 1971), a Orogênia Greenville no Escu do Canadense (Doig, 1977), as manifestações tecto-magmātica-metamörficas associadas a um evento tecto-genëtico do Ciclo Kibariano no continente Africano e Oriente Médio (Kröner, 1977) e uma fase de intensos falhamentos transcorrentes com o desenvolvimento de espessas faixas milonītico-cataclāsticas registradas no Escudo Guianense (Barrow, 1969; Priem et a1., 1971; Be11izzia, 1968). No Brasil tambēm ocorrem fenômenos correlatos; assim, em toda região Amazônica tem sido encontradas amplas evidēncias de um episódio milonītico-cataciāstico de extensão continental, com granitos associados, bem como uma sequência de granitos intrusivos e vulcâ- 
nicas diversas na Província Estanīfera de Rondōnia (Priem et a 1. 1971; Amara1, 1974). Os Grupos Araxā e Andrelândia, correspondentes ao Ciclo Uruaçuano, foram datados preliminarmente em pelo menos $980 \mathrm{m.a}$. (Hasui e Almeida, 1970), sendo que no substrato do primeiro ocorrem extensas faixas milonitico-cataclästi cas mais antigas (Almeida, 1978). Em Hama et al. (1979) são tecidas considerações sobre idades correlatas na região SSW de Mi nas Gerais e E do Estado de São Paulo, onde se tenta relacionälas a um evento principalmente milonitico-cataclästico associado a um estägio de evolução da crosta mundial.

Tambēm Fiori et al. (1978), Fiori (1979) e Artur et al. (1979), atravēs de relações estruturais, interpretaram tentativamente para a mesma região, um evento compressivo ocorrido nessa mesma ēpoca. Merece ainda destacar que a $3 a$. fase de dobramento, descrita em capitulo anterior, encontra-se bastante evidente na ārea onde foram coletadas as amostras da isōcrona de referência da Figura 23.

Alēm disso, duas idades K-Ar, uma com $1103 \pm 20$ m.a. apresentada pelo anfibolito do afloramento 14 e outrá de $1036 \pm 45 \mathrm{~m} . \mathrm{a}$. obtida por Hasui e Hama (1972) nas proximidades de Jundiai, poderiam estar relacionadas com a época de resfriamento de um fluxo de calor ligado a um evento tecto-termal.

Por outro lado, o valor apresentado pela isōcrona da Figura 23, poderia representar apenas uma re-homogeneização parcial de rochas mais antigas durante o Ciclo Brasiliano. Esta conclusão esbarra no bom alinhamento exibido pelos pontos anali ticos de amostras oriundas de afloramentos diferentes, ao conträrio do eque de amostras que deveria necessariamente ocorrer.

A Figura 24 apresenta uma isōcrona obtida a partir de sete amostras de migmatitos dos afloramentos 58 e 59 dis tantes entre si cerca de $500 \mathrm{~m}$, entre os $\mathrm{km} 26$ e 27 da rodovia Itapira-Lindóia. A dispersão relativa dos pontos em relação a isōcrona, pode ser considerada como sendo normal para rochas desta natureza, hỉbridas. A idade de $600 \pm 30 \mathrm{~m} . \mathrm{a}$. exibida pela isōcrona, aproxima-se, como jā descrito añteriormente nas deter minações K-Ar, da fase tardi-tectōnica do Ciclo Brasiliano.Trata-se da re-homogeneização do gnaisse regional pela profusa injeção de material granītico mais jovem. A razão inicial $\mathrm{Sr}^{87}$ / 


$$
\mathrm{Sr} / \mathrm{Sr} 86
$$

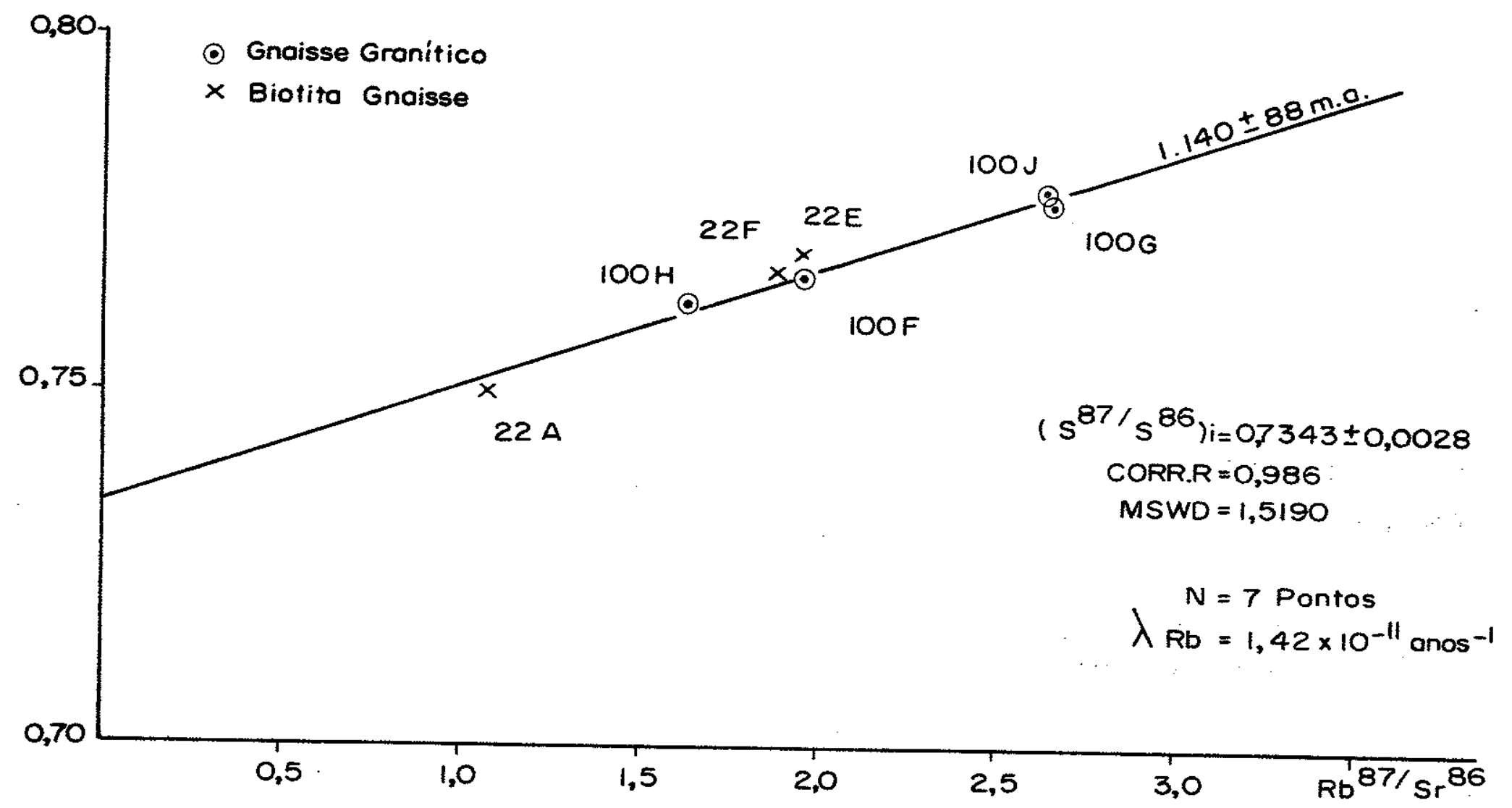

Figura 23 - Diagrama isocrónico Rb/Sr do gnaisse granitico do afloramento 100 e do biotita gnaisse do afloramento 22 . 
$\mathrm{Sr}^{86}$ de $0,7114 \pm 0,0012$ relativamente a1ta, pode ser considerada. normal para estas rochas. Estudos geoquimicos realizados por Wer nicḱ e Gomes (1977) revelaram uma origem profunda (na base da crosta) para o magma granītico do Grupo Pinhal, responsāvel tam bēm pela migmatização destas rochas regionais.

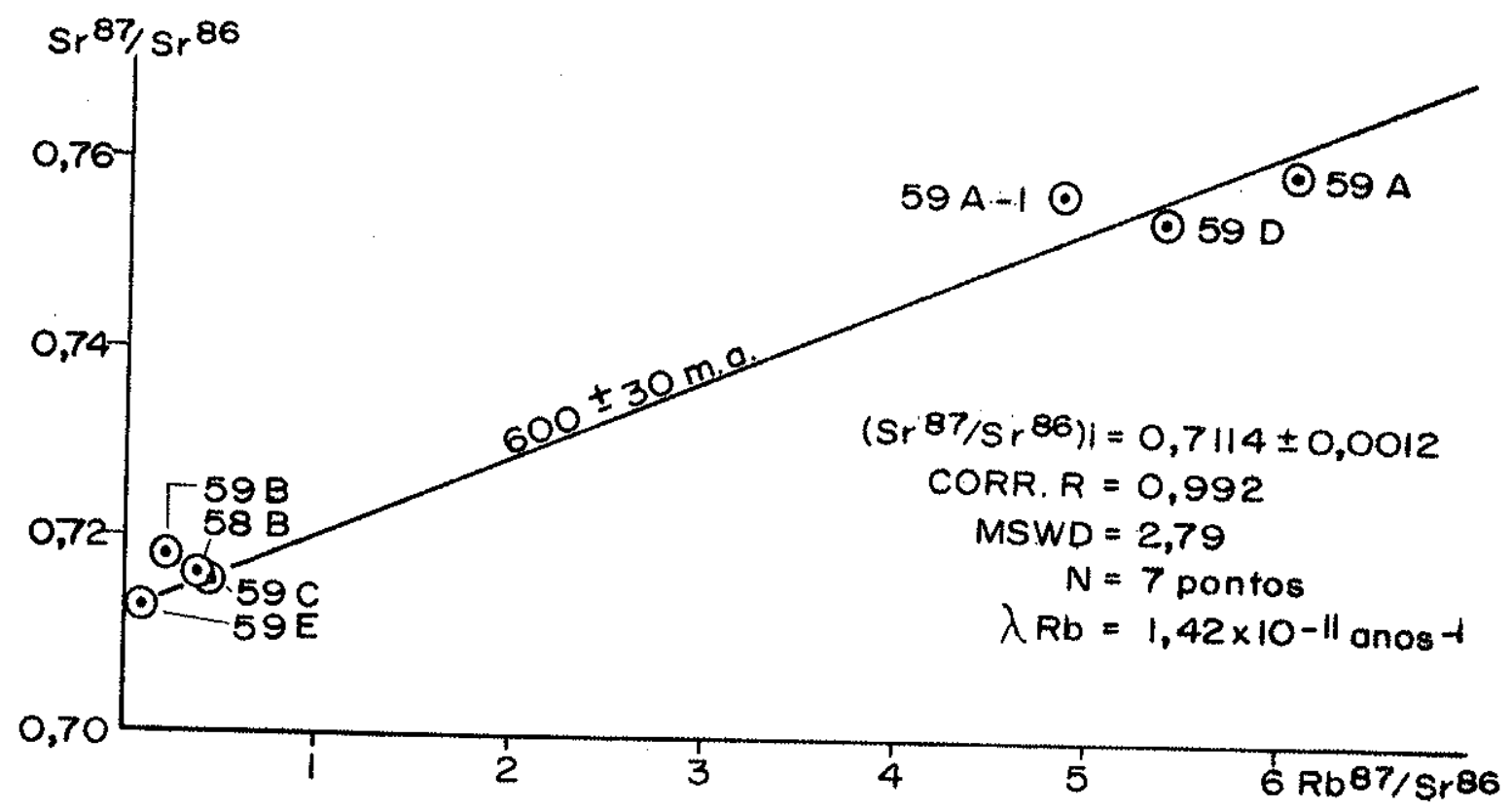

Figura 24 - Diagrama isocrōnico Rb/Sr dos migmatitos dos afloramentos 58 e 59 .

Na Figura 25 estão representadas, de forma sinōpti ca, as principais linhas isocrōnicas obtidas na ärea mapeada. os dados mostram boa coerēncia com o padrão geocronolōgico regional (capitulo II), permitindo sugerir para a ärea de Itapira eventos referiveis a 4 ciclos geotectōnicos lou, em parte, tecto- tērmicos ou mesmo apenas tectōnicos), que, associados ao reconhecimen to de possivelmente 4 fases de deformação (capĩtulo VI) com caracteristicas distintas, fornecem para a referida ārea uma evolu ção tectōnica policĩclica. Segundo esta interpretação, haveria uma vinculação entre as fases de dobramento $1,2,3$ e 4 com os ciclos Jequiē (sujeito a confirmação), Transamazōnico, Uruaçuano (?) e Brasiliano, respectivamente. Tambëm o caräter polimetamörfico das rochas (capitulo V), sucessivamente deformadas, $\bar{e}$ indicativo de vārios fluxos de calor de âmbito regional, sob regimes 
de temperatura e pressão distintas e que encontram os seus refle xos nas isōcronas $\mathrm{Rb}-\mathrm{Sr}$ e datações $\mathrm{K}$-Ar referíveis a värios ciclos. Alēm disso, os trabalhos de campo (capittulo IV) permitiram discriminar associações geolögicas nitidamente distintas, que podem ser referidas, pelo menos em parte, a diferentes eventos geradores de rochas. Contudo, não foi possĩvel a caracterização de associações litolögicas seguramente relacionäveis ao suspeito ci clo Uruaçuano, o que o tornaria, na ärea em foco, um evento com caracterīsticas de remobilização e de rejuvenescimento, e não um ciclo geotectōnico na concepção clässica. 


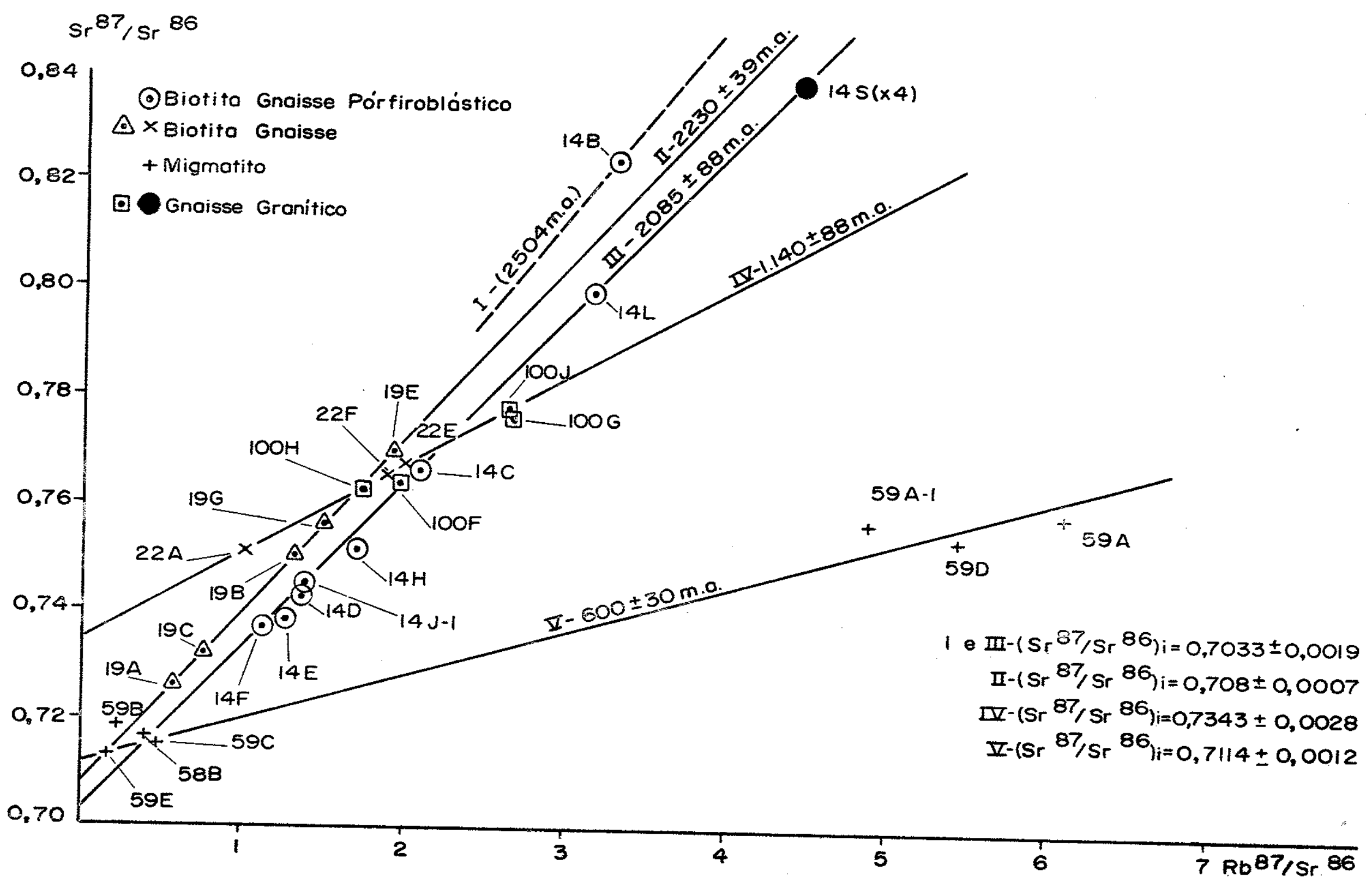

Figura 25 - Representação sinōptica das isōcronas das rochas metamörficas dos ärredores de Itapira-SP. 


\section{OCORRENCIAS DE INTERESSE ECONOMMICO}

Com exceção de alguns materiais de aplicação na indūstria de construção, a ārea ora estudada ē bastante pobre na ocorrēncia de minerais e rochas potencialmente econômicas. Menor papel é desempenhado pelas ocorrēncias de mārmore e amianto,atual mente com suas reservas praticamente esgotadas. 0s depōsitos de manganês e corpos de pegmatitos não oferecem atē o momento, condi ções minimas de rentabilidade que permitam a sua exploração.

\section{Materiais de Construção}

Restringe-se essencialmente na exploração de material para conservação de estradas, pedras britadas, areia para construção e argilas de aplicação na indūstria da cerāmica.

Duas pedreiras alojadas em biotita hornblenda gnaisses, uma à esquerda do Rio do Peixe nas proximidades da rodo via Itapira-Jacutinga e outra, na mesma rodovia, cerca de $1 \mathrm{~km}$ ao norte do vilarejo de Barão Ataliba Nogueira, serviram como fonte de pedras britadas por ocasião da pavimentação da rodovia Amparo Itapira-Jacutinga. Atualmente encontram-se abandonadas.

Na rodovia Itapira-Mogi Mirim, quase no limite oes te da ārea, situa-se uma pedreira em muscovita quartzito feldspātico decompostos, de propriedade da Estrada de Ferro FEPASA, que a 1 ém de suprir as necessidades da Companhia, é empregado na manutenção das estradas locais sem pavimentação.

Depōsitos aluvionares, constituīdos principalmente de argilas, são encontrados basicamente ao longo de boa parte do Rio do Peixe e praticamente em toda a extensão do Ribeirão da Penha, que apresentam largas planīcies de inundação. Apesar de vāa rias olarias utilizarem a argila no fabrico de tijolos e telhas,a comercializaçäo acha-se restrita ao pequeno mercado local.

A areia para a indūstria da construção civil ē retirada diretamente do Rio do Peixe por bombas de sucção, instaladas em vārios pontos de todo seu curso na ārea mapeada. A areia ali extraîda, abastece vārias cidades circunvizinhas de Itapira. São inexistentes terraços fluviais bem desenvolvidos onde a reti- 
rada pudesse ser executada a seco.

\section{Märmore Calcitico}

A maior ocorrência encontra-se na Pedreira Fortale $z a$, situada na fazenda homónima, na parte centro-leste da " ärea. Trata-se de märmore bastante homogêneo e com teores entre 1 e $2 \%$ de Mgo, pröprio para o fabrico da cal.

Sua exploração que remonta em mais de 20 anos, foi utilizada durante cerca de 15 anos para o fabrico da cal. Atualmente o märmore vem sendo moĩdo para ser aplicado como corretivo de solos. Com uma produção mensal inferior a 600 toneladas de pö, essa pedreira possui uma reserva economicamente explorāvel estima da para mais dois ou três anos apenas.

Uma outra ocorrência, extremamente restrita, encon tra-se nas margens do Cörrego da Mata no limite dos Estados de São Paulo e Minas Gerais, a leste da ärea. Esta ocorrēncia foi explorada para fabricação de cal e encontra-se atualmente abandonada devido à reduzida quantidade das rochas carbonäticas.

\section{Amianto}

0corre nos corpos de meta-peridotitos localizados à WSW da Fazenda Cristālia. O amianto compõe pequenos diques de espessura centimētrica ou concentra-se em bolsões, com dimensões atë submëtricas, inclusos na rocha matriz alterada. 0 comprimen to mëdio de suas fibras situa-se entre 1 e $2 \mathrm{~cm}$, raramente ultrapassando $3 \mathrm{~cm}$.

Sua exploração que foi abandonada e retomada vārias vezes, apresenta atualmente uma produção pequena (no māximo $1000 \mathrm{~kg}$ por mês) e extremamente irregular, sendo interrompida constantemente por falta do minērio, que é localizado na base da tentativa atravēs da abertura de poços. Esta, que é a ūnica ocorrência que vem sendo explorada em toda a região, encontra-se em vias de ser abandonada definitivamente.

4. Pegmatitos e Vejos de Quartzo 
Os veios de quartzo e pegmatitos são relativamente restritos na ārea estudada, constituĩndo pequenos corpos de forma tabular com espessuras predominantemente centimëtricas e raramente submétricas. Apenas foi constatado um caso em que um veio de quartzo leitoso atinge cerca de 5 metros de espessura. Está localizado na rodovia Itapira-Lindóia, prōximo ao $\mathrm{km} 34$. Tanto os peg matitos como os veios de quartzo guardam estreita relação com os planos de foliação das rochas regionais e com os sistemas de juntas resultantes das diversas fases de fraturamento que afetaram a àrea.

Mineralogicamente são simples, predominando os veios de quartzo leitoso, e subordinadamente os pegmatitos compos tos por quartzo, feldspato potāssico e alguma biotita. Apresentam textura grosseira com cristais variando entre as dimensões subcentimëtricas a centimētricas e intensamente fraturados.

São mais frequentes nos arredores da Fazenda Fortaleza em direção à Serra dos coutos, não sendo verificado nenhum corpo em lavra ou jă lavrado. A ūnica ocorrência em fase de pesquisa, ainda em gnaisses com textura pegmatitica, encontra-se na encosta leste da Serra do Matão, mas com pouca perspectiva de via bilidade econômica.

\section{Gonditos}

As concentrações mais expressivas constituem, como podem ser vistas no mapa litológico-estrutural anexo, uma estreita faixa descontinua a $W$ da Fazenda do Jardim, na porção sul da ărea, bem como duas a NE da cidade de Itapira. Entretanto, como $j \bar{a}$ discutido no capitulo $V$, è bastante frequente, em grande parte da ärea, a ocorrência de diminutos leitos ou corpos lenticulares, que não oferecem as minnimas condições de rentabilidade para sua exploração.

OS gonditos são rochas compostas essencialmente por granada e quartzo, caracterizados por uma estrutura ritimica, quase sempre alterados para um material pulverulento, rico em ōxi dos e hidrōxidos de manganēs.

A liberação desses compostos de ōxidos e hidrōxidos de manganềs pela ação supērgena, produz teores com grande va- 
riabilidade tanto no aspecto de intensidade como no teor. Anālises quïmicas do minërio, realizadas por Wernick et al, (1976a)pa ra gonditos de Socorro e Itapira (este ültimo, corresponde ao corpo situado mais a noroeste de Itapira), revelaram ampla varia ção no teor do manganês, de 7 a $30 \%$, podendo localmente atingir concentrações superiores a $50 \%$.

Economicamente estes gonditos podem vir a despertar interesse. Uma prospecção mais detalhada poderä fornecer dados dimensionais e estruturais de seus depósitos. A relação estrutura-corpo mineral deve ser determinada para se obter o comportamento e a distribuição espacial desses depōsitos. 


\section{TENTATIVA DE UMA SINTESE DA EVOLUÇAOO GEOLOGICA}

Neste capitulo, tentar-se-ä fazer, com base no con junto de dados apresentados nas päginas anteriores, uma sintese da evolução geolögica que moldou a região de Itapira, nos seguin tes termos:

1. Estabelecimento de um substrato de natureza siā lica de idade arqueana resultante do metamorfismo de um educto mal definido, (isōcrona da Figura 22 , com idade de $2230 \pm 39 \mathrm{~m}$. a.).

2. Soerguimento da crosta e erosão atē o nível de anatexia que, ora exposto, exibe uma fase de deformação com do bras irregulares, denotando origem dominantemente por fluxo num meio de elevada plasticidade. Tentativamente, esta deformação $\bar{e}$ atribuĩda à la fase de dobramento detectada na ārea.

3. Sobre o material erodido iniciou-se uma intensa deposição de sedimentos, durante o Ciclo Transamazônico, representada por uma sequência clasto-psamittica, de natureza arcosia na a pelitica, e grauvacas ricas em plagiocläsio, com intercalações de sedimentos clasto-químicos impuros, psamitos manganesife ros a pelitos manganesifferos impuros. Areias feldspäticas ocorrem tanto sob a forma de pequenas lentes quanto coristituindo horizontes mais espessos e persistentes. Localmente, houve deposição de sedimentos carbonāticos puros. Associados à contĩnua subsidência (que, pelas caracterīsticas dos metassedimentos, foi räpida e contĩnua, com a presença de lagos em condições favoräveis à precipitação de sedimentos quïmicos carbonāticos), ocorreram manifestaçöes de magmas bäsicos hipoabissais e efusivos, ao lado le corpos ultrabāsicos, ligados provavelmente ä primeira fase alagmätica ou fase ofiolỉtica da evolução geossinclinal.

4. Metamorfismo de alta pressão dos referidos depö sitos resultando rochas da fäcies anfibolitica (com paragêneses minerais evidenciando condições de brando a mëdio grau dentro desta fācies) e, localmente, anatexiticas, ocasionando a gēnese do Grupo Amparo durante o Ciclo Transamazōnico, (isöcronas das Figuras 19 e 21 , respectivamente com idades de $2.085 \pm 88 \mathrm{~m} . \mathrm{a}$. e $1.918 \pm 72 \mathrm{m.a.}$.

O metamorfismo foi acompanhado de forte deformação 
que, alëm de produzir um dobramento isoclinal nas rochas do Grupo Amparo, provocou um retrabalhamento mais ou menos intenso do seu embasamento. Nos metassedimentos do Grupo Amparo, as dobras são configuradas pelo antigo acamamento sedimentar, tendo-se desenvol vido uma intensa foliação em posição plano axial. Essa foliação foi caracterizada como sendo de transposição e, em toda ärea investigada, desenvolve-se paralelamente aos planos de acamamento dos metassedimentos transamazonicos. Esta fase de dobramento corresponde à 1a. fase de deformação dos referidos metassedimentos e provavelmente $\bar{a} 2$ a.fase de dobras da região. Sua direção estrutural original $\bar{e}$ de difícil determinação, devido não somente aos redobramentos posteriores, como tambēm à movimentação de blocos causada por intensa tectônica rüptil. O fluxo de calor superou, no tempo, a deformação, como bem o demonstra a existência de material recristalizado principalmente em ápices de dobras intrafolia res.

5. Redobramento no Ciclo Uruaçuano (isöcrona da Figu ra 23 , com idade de $1.140 \pm 88 \mathrm{~m} . \mathrm{a}$.$) correlacionado tentativamen-$ te a um evento tecto-tērmico ou mesmo apenas tectônico. As estruturas, representadas por dobras cujo traço axial tem direção geral NW a NNW, são de abertas a isoclinais, sem mostrar, contudo, nîtido desenvolvimento de foliação plano axial. Esta fase è seguramente posterior ā $2 a$ : fase de dobramento, pois redobra a foliação gerada na fase anterior.

Os dados petrogrāficos não apresentam evidēncias que permitam caracterizar as rochas integrantes da isöcrona da Figura 23, como sendo seguramente cogenëticas ao Ciclo Uruaçuano, jă que são patentes sinais de sucessivas cristalizações e neoformação de minerais, indicando sua longa histöria evolutiva metamörfica.Tais dados indicariam, possivelmente, a presença de mais de um fenömeno de rejuvenescimento de rochas mais antigas.

6. Metamorfismo no Ciclo Brasiliano (datações K-Ar, Tabela 6) que atingiu as condições mais altas da fäcies . xistos verdes, provocando diaftorese generalizada nos metamorfitos prē-existentes da fäcies anfibolītica. 0 metamorfismo retrögrado $\bar{e}$ caracterizado por numerosas reações, tais como: granada $\rightarrow$ clorita, diopsidio hornblenda, hornblenda castanhat hornblenda verde $\rightarrow$ clorita, hornblenda $\rightarrow$ biotita, plagiocläsio $\rightarrow$ epidoto, etc..

Acompanhando o metamorfismo ocorre a $4 \mathrm{a}$. fase de 
dobramento com direção axial geral NE-SW. Esta fase, que afeta tanto a 2a. quanto a $3 a$. fase de dobras, ē a mais recente identi ficada na ārea. As dobras são abertas, do tipo concēntricas,geradas por processo flexural e sem o desenvolvimento de foliação plano-axial.

Localmente, ocorre migmatização das rochas metamōr ficas por injeção de material granītico,que estaria associado a uma fase tardi-tectônica do Ciclo Brasiliano (isócrona da Figura 24, com idade de $600 \pm 39 \mathrm{~m} . \mathrm{a}$.$) , e alojamento de corpos magmāti-$ cos granīticos, na parte oeste da ārea, referentes ao Grupo Pinhal.

0 levantamento do cinturão orogenētico teria ocorrido a cerca de $500 \mathrm{~m} . \mathrm{a}$. atrās, (534 $\pm 7 \mathrm{~m}$.a. obtido pelo mētodo K-Ar em biotita de biotita gnaisse, Tabela 6).

7. Deposição de sedimentos molassóides em .bacias tectônicas seguidas de deformação e anquimetamorfismo no final do Ciclo Brasiliano (ao redor de $534 \pm 20 \mathrm{~m}$.a.s segundo Hama e Cunha, 1977), resultando na gênese das Formações Eleutērio e Pou so Alegre. A presença destes depōsitos molassōides é indicativa de uma certa estabilidade na região.

8. Enrijecimento regional e desenvolvimento de intensa deformação pōs-cristalina afetando toda a região, cerca de $485 \pm 15 \mathrm{~m} . \mathrm{a}$. (idade em granitos cataclasados, Hama e Cunha, 1977; Hama et al., 1979). A milonitização sobrepõe-se às principais direções estruturais dos dobramentos. Desenvolve espessas faixas milonītico-cataclásticas com a ocorrência mais expressiva da ārea representada pelo sistema de falhamento de Jacutinga com direção geral NE-SW.

9. Erosão e aplainamento sucessivos seguidos de depōsitos sedimentares, observando-se, na região, a Superfície I taguā, prē-carbonīfera, e depōsitos permo-carbonîferos de arenị tos, siltitos e argilitos flūvio-glaciais, referīveis ao Grupo Tubarão. Estão restritos à parte oeste da ārea de Itapira.

10. Novo levantamento seguido de erosão com o estabelecimento da superfície das Cristas Médias ou Japi.

11. Sedimentação dos depōsitos neo-cenozóicos, preservados na ārea principalmente na porção ao sul do vale do Rio 
do Peixe, cujas fontes dos sedimentos säo essencialmente as ro chas cristalinas circunvizinhas. São sedimentos predominantemente arenosos, mais ou menos inconsolidados e mal selecionados, se parados das rochas sotopostas por uma linha de seixos.

12. Continuo soerguimento que vem afetando a ārea desde o Terciārio Superior (Soares e Landim, 1975), com conse quente basculamento dos blocos para norte, atravës da reativação ao longo de antigos planos de falhamentos. Esta epirogēnese pos tiva $\vec{e}$ responsāvel pela intensa erosão que a ārea vem sendo submetida, com a destruição dos depōsitos permo-carbonifferos e consequente exumação do assoalho cristalino prē-glacial. Tambēm $\bar{e}$ responsāvel pela preservação de restos de sedimentos neo-cenozōi cos, sempre na parte sul dos principais vales, pelo adernamento dos blocos para norte.

Depōsitos de aluvião, constituĩdos por areia, cascalho e argila, estão restritos aos niveis de base local. Os depōsitos de argila e areia apresentam, localmente, certa importān cia econömica.

13. A atual geomorfologia da ärea è totalmente con trolada pelos tipos litolögicos presentes e pela tectónica moder na, com movimentação diferencial de blocos adernados. 


\section{$X$. CONCLUSOES}

Os estudos geolōgicos, petrogräficos, geocronolōgi cos e estruturais revelaram uma evolução nitidamente policiclica para as rochas cristalinas que bordejam a Sinecclise do paranä nos arredores de Itapira.

Os dados radiomētricos permitiram a constatação de eventos referiveis provavelmente a 4 ciclos geotectônicos ou, em parte, tecto-tērmicos ou mesmo apenas tectōnicos, com idades arqueana, representados por metatexitos localmente expostos e refe riveis ao Ciclo Jequiē (sujeito a confirmação), transamazōnica (Grupo Amparo), uruaçuana e brasiliana (Grupo Pinhal e Formação Eleutērio).

Atravēs de critërios estruturais, foi possĩvel o reconhecimento de provavelmente 4 fases de dobramento com características distintas. Da superposição das fases de dobramento 2, 3 e 4 resultaram padrões de interferēncia caracteristicos, em parte similares aos descritos por Fiori et al. (1978, Figura 2). Entre estes, destacam-se estruturas fechadas resultantes da superposição de dobras isoclinais de direções aproximadamente orto gonais (fase 3 sobre fase 2), e ondulações de traços axiais ( $f \underline{a}$ se 4 sobre fase 3 ).

Segundo esta interpretação, haveria uma vinculação entre as fases de dobramento $1,2,3$ e 4 , com Ciclos Jequiē (?), Transamazōnica, Uruaçuano e Brasiliano, respectivamente.Esta vin culação coaduna-se com os resultados obtidos por Fiori et al. (1978, 1980), Fiori (1979) e Fiori e Choudhuri (1979) ao inivel regional no qual a ārea em foco se acha inserida. Entretanto,não pode ser descartada a hipötese de que algumas fases de dobramento sejam, em realidade, deformações polifásicas ligadas a um ou mais ciclos, como sugerido por Hasui e Sadowski (1976) para a re gião de São Paulo, jā que a sequência das 4 fases de deformação são compatĩveis com dobramentos que ocorrem em sistemas rochosos caracterizados por um enrijecimento progressivo.

Não obstante, o carāter polimetamörfico das rochas sucessivamente deformadas $\bar{e}$ indicativo de vārios fluxos de calor de caräter regional, sob regimes de temperatura e pressão distin 
tos, que encontram os seus reflexos em isōcronas Rb-Sr e datações K-Ar referíveis a värios ciclos.

os trabalhos geolögicos executados permitiram discriminar, tambēm associações litolögicas nitidamente distintas (ca pitulo IV), que podem ser referidas, pelo menos em parte, a distintos eventos geradores e deformadores de rochas.

A ação do Ciclo Brasiliano não só estā retratada atravēs de atividades magmäticas grañ̄ticas (Figura 24, com $600 \pm$ 30 m.a.), mas tambēm, atravēs de numerosas datações $K-A r, o$ que $\underline{e}$ videncia um fluxo de calor suficiente para re-homogeneizar isotopicamente sistemas de filo-e inossilicatos. Tais temperaturas situam-se entre 3000 e $4000 \mathrm{C}$, e são confirmadas por evidéncias petrogräficas, dentre as quais podemos citar a ocorrência generalizada, em toda ārea, de paragēnese ligada a um metamorfismo retrögrado que atingiu a parte superior da fácies xistos verdes.

Contudo, näo foi possivel a caracterização de associações litolögicas seguramente referíveis ao Ciclo Uruaçuano, o que faz suspeitar que este evento tenha, na ārea em foco, muito mais caracteristicas de rejuvenescimento do que as de um ciclo geotectōnico na sua concepção clāssica. 


\section{$X I$. AGRADECIMENTOS}

Queremos deixar os nossos mais sinceros agradecimen tos as pessoas e entidades que direta ou indiretamente colaboraram para a realização do presente trabalho.

Cabe-nos aqui, a mais profunda gratidão ao Professor Doutor Koji Kawashita, do Departamento de Geologia Geral do Instituto de Geociēncias da Universidade de São Paulo, orientador da tese, que colaborou de maneira direta atravēs de estīmulo, sugestões e constantes críticas durante as värias etapas de prepara ção deste trabalho;

ao Professor Doutor Eberhard Wernick, do Departamen to de Mineralogia e Recursos Minerais, do Instituto de ... Geociēn cias e Ciências Exatas da UNESP, "Campus" de Rio Claro, pela dedi cação e interesse que demonstrou ao acompanhar o desenvolvimento do presente trabalho, pelas viagens ao campo e pelas longas discussões que ocasionaram o surgimento e o desenvolvimento do tema bàsico;

ao Professor Doutor Raphael Hypōlito, pela execução das anālises químicas em rochas;

ao Professor 01 avo Josē Bortolotto, da Universidade Federal de Santa Maria (RS), pōs-graduando do Departamento de Mineralogia e Petrologia do Instituto de Geociēncias da Universidade de São Paulo, pela leitura crítica e cuidadosa revisão dos manuscritos;

aos professores dos Departamentos de Mineralogia e Petrologia e de Geologia Geral, do Instituto de Geociencias da Universidade de São Paulo, que contribuiram na elaboração do presente trabalho, atravēs de sugestões, crĩticas e debates;

a todos os tēcnicos do Centro de Pesquisas Geocrono lögicas, pelo auxilio prestado durante as diversas fases analiticas requeridas nas determinações radiomētricas;

à Senhorita Itacy Kroehne, pelos trabalhos na elabo ração dos mapas e figuras;

à Senhora Melany Thereza Isauk e Senhor claudio Hopp, pela confeç̧ão das lāminas delgadas; 
trabalho de datilografia;

à Senhora Claudete Salinas Franzosi, pelo zeloso

à equipe da Seção Gräfica, particularmente em nome do Senhor Jaime Alves da Silva;

à Fundação de Amparo à Pesquisa do Estado de São Paulo (Processo no 77/533) pelo auxîlio financeiro concedido para os trabalhos de campo, e ao Conselho Nacional de Desenvolvimento Cientifico e Tecnológico pela concessão de bolsa de Mestra do, durante a vigência da qual foi realizada grande parte deste trabalho. 
XII. BIBLIOGRAFIA

ALMEIDA, F. F.M. - 1964 - Fundamentos geolögicos do relevo paulis ta. In "Geologia do Estado de São Paulo". São Paulo, Secreta ria da Agricultura, I.G.G. Bo1. no 41, pp. 169-263.

ALMEIDA, F.F.M. - 1978 - Evolução dos Cratons Amazônico e do São Francisco com a de seus homōlogos do Hemisfërio Norte. Anais do XXX Congr.Bras.Geol. Recife, Vol. 6, pp. 2393-2407.

ALMEIDA, F.F.M. e BARBOSA, 0. - 1953 - Geologia da Quadrícula de Piracicaba e Rio Claro, Estado de São Paulo. D.N.P.M/D.G.M., Bol. 43. pp.87.

ALMEIDA, F.F.M.; HASUI, Y. e NEVES, B.B.B. - 1976 - The: upper precambrian of South America. Bol. I.G.U.S.P., Vo1.7,pp.4580.

ALMEIDA, F.F.M.; AMARAL, G.; CORDANI, U.G. e KAWASHITA, K.-1973The Precambrian Evolution of the South American Cratonic Mar gin, South of the Amazon River, In "Nairn, A.G.M. e Stehli, F.G.". The 0cean Basin and Margins, Vol.1, Cap.11, pp. 411446 .

AMARAL, G. - 1974 - Geologia prē-cambriana na Região Amazônica. Tese de Livre-Docência-IGUSP (inēdita). $212 \mathrm{pp}$.

AMARAL, G. e ROCHA CAMPOS, A.C. - 1969 - Limite Permo-Triássico na América do Sul. Soc.Bras.Geo1. - Nūcleo de São Paulo.Bol. Especial no 1 (Resumo das Comunicações do XXIII Congr. Bras. Geo1.): pp. 88-89.

AMARAL, G.; CORDANI, U.G.; KAWASHITA, K. e REYNOLDS, J.H. -1966Potassium-argon dates of basaltic rocks from Southern Brazi1. Geoch.et Cosm.Acta, Vo1.30. pp. 159-189. Oxford.

ANDRADE, S.M. e SOARES, P.C. - 1971 - Geologia do Centro- Leste do Est.de São Paulo. Petrobrās-Desul, Rel. 407.

ARTUR, A.C.; WERNICK, E. e KAWASHITA, K. - 1979 - Dobramentos Su perimpostos na Região de Itapira (SP): Caracterização e crow nologia. Atas do II Simpósio Regional de Geol. (Soc. Bras. Geol. - Nücleo de São Paulo), Vol.1. pp. 59-70.

BADGLEY, P.C. - 1959 - Structural Methods for the Exploration Geologist, Harper \& Brothers, New York, $280 \mathrm{p}$. 
BARBOSA, 0. e ALMEIDA, F.F.M. - 1949 - A Sërie Tubarão na Bacià do Tietê, SP. DNPM/DGM, Notas Preliminares e Estudos, no:48, $16 \mathrm{pp}$.

BARBOSA, 0. e GOMES, F.A. - 1958 - Pesquisa de Petröleo na Bacia do Rio Corumbataî, Estado de São Paulo. DNPM/DGM - Bol. 171.

BARROW, C.N. - 1969 - K'Mudku mylonite episode notes on the Stra tigraphy of Guiana. Proc.VII Guiana Conf., Paramaribo.

BELLIZZIA, M. - 1968 - Idades isotōpicas de las rocas Venezoelanas. Min.Hidrocarburos, Bol.Geol. X(19), Caracas. pp. 356380 .

BENCE, A.E. e ALBEE, A.L. - 1968 - Empirical correction factores for the electron microanalysis of silicates and oxides. Jour nal of Geology. Vol.76. pp. 382-403.

BJORNBERG, A.J.S. - 1965 - Sedimentos Post-Cretäceos do Leste do Estado de São Paulo. Tese de Livre-Docência - IGUSP (Inēdi.. ta). $190 \mathrm{p}$.

BJORNBERG, A.J.S. - 1969 - Contribuição ao estudo do Cenozóico Paulista: Tectónica e Sedimentologia. Tese de Professor Titu lar da EESC-USP (Inëdita). $128 \mathrm{p}$.

BJORNBERG, A.J.S. e LANDIM, P.M.B. - 1966a - A Formação Rio C1aro (neo-cenozöico) no interior do Estado de São Paulo. Soc. Bras.Geol. - Nūcleo do Rio de Janeiro - no 1. pp. 67-68.

BJORNBERG, A.J.S. e LANDIM, P.M.B. - 1966b - Contribuição ao Estudo da Formação Rio Claro (Neo-cenozóico).Soc.Bras.Geol., Vol. 15, no 4. pp. 43-67.

BRAUN, G. - 1969 - Computer calculated counting nets for petrofa bric and structural analysis. N.Jb. Miner. Mh., Vol. 10, pp. 469-476.

CARVALHO, A.; MELFI, A.J.; BITTENCOURT, I.; QUEIROZ NETTO, J.P.e NAKASHIMA, R. - 1967 - Sedimentos Neo-cenozöicos na Area de Campinas. Bol.Paran.Geoc. Vol.26. pp.71-72.

CHOUDHURI, A.; FIORI, A.P.; WINTERS, A.A.M.; BETTENCOURT, J.S. e ROORIGUES, J.E. - 1978 - A note on small bodies of eclogite as inclusiones in high grade gneisses, Nort of Pouso Alegre, Miras Gerais. Rev.Bras.Geoc. Vol.8, no 1.pp. 63-68. 
CHRISTOFOLETTI, A. e QUEIROZ NETO, J.P. - 1966 - Os sedimentos da Serra de Santana. Bol. Paran. Geogr., 18/20, pp. 231-245.

CIPRIANI, C.; SASSI, F.P. e SCOLARI, A. - 1971 - Metamorphic White micas: definition of paragenëtic field. Schweiz. Miner. Petr.Mitt., Vo1.51.pp. 259-302.

CORDANI, U.G. e BITTENCOURT, I. - 1967 - Determinação de idade potāssio-argōnio em rochas do Grupo Açungui. An.XXI . Congr. Bras.Geol. Curitiba. pp. 218-233.

CORDANI, U.G. e KAWASHITA, K. - 1971 - Estudo geocronolögico pelo mëtodo $R b-S r$ de rochas graniticas intrusivas no Grupo Açungui. An. XXV Congr.Bras.Geol. São Paulo.pp. 105-110.

CORDANI, U.G.; DELHAL, J. e LEDENT, D. - 1973 - Orogēneses superposēs dans le precambrian du Brēsil Sud-Oriental (Etate de Rio de Janeiro et de Minas Gerais). Rev.Bras.Geoc.no 3.Vol.1. pp. 1-22.

CORDANI, U.G.; HALPERN, M. e BERENHOLC; M. - 1974 - Comentārios sobre as determinações geocronolögicas da Folha de Porto Alegre. In "Carta Geolögica do Brasil ao Milionësimo. Folhas Por to Alegre (SH-22) e Lagoa Mirim (SI-22). Texto explicativo", MME-DNPM, Brasilia.pp. 70-84.

DOIG, R. - 1977 - Rb/Sr Geocronology and Evolution of the Greenvi 17 Province in North Western Quebec, Canadä. Geol.Soc.Bul1., Vol.88. pp. 1843-1856.

EBERT, H. - 1955 - Pesquisas na parte sudeste do Estado de Minas Gerais e no Poliggno das Secas. DNPM Rel.An.Dir.Div.Geo1.Min. pp. $79-89$.

EBERT, H. - 1956 - Beitrag zur GTiederung des Prakambriuns in Minas Gerais. Geol. Rundschau, 45 (3): $471-521$.

EBERT, H. - 1957 - A tectönica do sul do Estado de Minas Gerais. DNPM., Rel.An.Div.Geo1. Min. 97-107; pp. 136-137.

EBERT, H. - 1958 - Discordãncias prē-cambrianas em Carandaĩ,Minas Gerais. DNPM, Bol. Div. Geol. Min., 183, $48 \mathrm{pp}$.

EBERT, H. - 1962 - Baustil und Regional-metamorphose in prakambrius Grundgebirge Brasiliens: Tscherm. Min. Petr.Mitt.,8(1): $49-81$. 
EBERT, H. - 1963 - The manganese bearing Lafaiete Formation as a guide horizont in the pre-cambrian of Minas Gerais. An.Acad. Bras.ciênc.; Vol.35.pp. 543-559.

EBERT, H. - 1971 - Os paraibides entre São João Del Rey (MG) e Itapira (SP), e a bifurcação entre Paraibides e Araxaides. Soc.Bras.Geol. - Nūcleo de São Paulo. Bol. Especial no 1 (Res mo das Comunicações do XXV Congr.Bras.Geol.) pp. 177-178.

EBERT, H. - 1974 - 0 Grupo Eleutērio e a Falha de Jacutinga (Nor deste de São Paulo). Soc.Bras.Geol. Nūcleo do Rio Grande do Sul. Bol. Especial nọ 1 (Resumo das Comunicações do: XXVIII Congr.Bras.Geo1.) pp. 726-730.

EBERT, H. e BROCHINI, M.F. - 1968 - Estudos estratigräficos . e geocronolögicos no Escudo Cristalino Brasileiro. Ciência e Cultura 20: 621-625.

ELLERT, R. - 1959 - Contribuição a geologia do Maciço de Poços de Caldas. Fac. Fil.Ciēn.Letras, USP. Bol. 237 (Geologia 18) $1-63 \mathrm{pp}$.

ELLERT, R.; BJORNBERG, A.J.S. e COUTINHO, J.M.V. - 1959 - : Mapa geolögico do Maciço Alcalino de Poços de Caldas. Dep. Geol. Paleont., Fac.Fil.Ciēnc.Letr., USP, 1:75000.

EUGSTER, H.P. e YODER, H.S. - 1955 - The join muscovite-paragonj te. Yb.Carnegie Instn.Wash., Vol.54.pp. 124-126.

EUGSTER, H.P.; ALBEE, A.L.; BENCE, A.E.; THOMPSON, J.B. e WALDBRAUN, D.R. - 1972 - The two-phase region and excess mixing properties of paragonite-muscovite crystalline solutions: Jour. Petrol. Vol. 13.pp. 147-179.

FIORI, A.P. - 1979 - Geologia da Região de Pouso Alegre - Machado: Anālises Estrutural de Dobramentos Superpostos. Tese de Doutoramento - IGUSP (Inëdita). $200 \mathrm{p}$.

FIORI, A.P. e CHOUDHURI, A. - 1979 - Fases de migmatização e dobramentos superpostos nas rochas granuliticas e nos migmatitos de Serrania e Machado (MG). Atas do II Simpōsio de Geol. Regional (Soc.Bras.Geol. - Nücleo de São Paulo). Rio Claro. Vol.1, pp. 47-58.

FIORI, A.P.; WERNICK, E. E BETTENCOURT, J.S. - 1978 - Evolução Policíclica na Região Nordeste do Estado de São Paulo. e 
äreas vizinhas do Estado de Minas Gerais. Anais do $x X X$

Congr.Bras.Ge01. Recife. Vol. 1. pp. 309-320.

FIORI, A.P.; WERNICK, E.; CHOUDHURI, A.; SOARES, P.C. e BITTENCOURT, J.S. - 1980 - Evolução geolögica da parte SW do Estado de Minas. (no prelo).

FRANCO, R.R. e COUTINHO, J.M.V. - 1957 - Charnockitos e rochas associadas no Municĩpio de Amparo e Socorro, Est.de São Pau10. An.Acad.Bras.Ciênc.Vol.28, nọ 3. pp. 303-311.

FULfaro, J.V. e SUGUIO, K. - 1968 - A Formação Rio Claro (Neo-ce nozōicol e seu Ambiente de Deposição. Bol. Inst.Geoc.Vol:20. pp. $45-60$.

GOMES, C.B.; COUTINHO, J.M.V. e OLIVEIRA, A.B. - 1966 - Paragasi ta em dolomitos metamörficos do Municĩpio de Tapiratiba, (SP). An.Acad.Bras.Ciênc. Vol. 38. pp. 39-46.

GOMES, C.B.; RUBERTI, E. e WERNICK, E. - 1976 - Caracterização quïmica de feldspatos de rochas graniticas. An.Acad... Bras. Ciènc., Vol.48.no 3. pp. 445-452.

GRASER, S. e NIGGLI, E. - 1967 - Zur Verbreitung der Phengite in den Schweizer Alpen. Ein Beitrag zur zoneographie der alpinen metamorphose. Etages Tect., Colloque de Neuchatel. Vol. 18. pp. 89-104.

GUIDOTTI, C.V. - 1966 - Variation of the basal specings of musco vit in sillimanite-bearing pelitic schists of NW Maine.Amer. Minera1., Vol.51. pp. 1778-1786.

GUIDOTTI, C.V. - 1969 - A comment on "Chimical study of minerals from the moine schists of the Ardnamurchan Area, Argyllshire Scotland" by B.C.M. Butler, and its implications for : the phengite poblem.Jour. Petrol. Vo1.10. pp. 164-170.

GUIDOTTI, C.V. - 1973 - Compositional variation of muscovite as a function of metamorphic grade and assemblage in metapelites from N.W.Maine. Contr.Minral. Petrol., Vo1.42. pp.33-42.

GUIDOTTI, C.V. - 1974 - Transition from staurolite to sillimanite zone, Rangely quadrangle, Maine. Geol.Soc. Amer., Bull. $85,475-490 \mathrm{pp}$.

GUIDOTTI, C.V. - 1978a - Muscovite and K-feldspar from two-mica adamellite in Northwestern Maine: Composition and petrogene- 
tic implications. Am.Minera1. Vo1.63, No 7-8. pp. 750-753. GUIDOTTI, C.V. - 1978b - Compositional variation of muscovite in medium-tohigh-grade metapelites of N.W. Maine. Jour.Amer. Mi nera1. Soc. Am. 63, pp. 878-884.

GUIDOTTI, C.V. e SASSI, F.P. - 1976 - Muscovite as petrogenetic indicator mineral in pelitic schists. Neues Jahrb. Mineral. Abh. 127, 92-142 pp.

HAMA, M. e CUNHA, H.C.S. - 1977 - Considerações sobre a idade ra diomētrica da Formação Pouso Alegre e dos granitos pōs- cambrianos da região sul do Estado de Minas Gerais e nordeste do Estado de São Paulo. Atas do I Simpösio de Geol. Regional (Soc.Bras.Geol. - Nūcleo de São Paulo) pp. 48-58.

HAMA, M.; ALgARTE, J.P.; KAEFER, L.Q. e ARTUR, A.C. - 1979 - Ida des $\mathrm{Rb} / \mathrm{Sr}$ e K/Ar na região sul-sudoeste de Minas Gerais e leste do Estado de São Paulo. Atas do II Simpōsio Regional de Geol. (Soc.Bras.Geol. - Nücleo de São Paulo), Rio Claro Vo1.1. pp. 71-86.

HASUI, Y. e ALMEIDA, F.F.M. - 1970 - Geocronologia do Centro-0es te Brasileiro. Bol.Soc.Bras.Geol., Vol.19, no 1. pp. 5-26.

HASUI, Y. e HAMA, M. - 1972 - Geocronologia do Grupo São Roque pelo mētodo potässio-argōnio. Rev.Bras.Geoc. Vol.2, no il. pp. $8-24$.

HASUI, Y.; PENALVA, F. e HENNIES, W.T. - 1969 - Geologia do Grupo São Roque. Anais do XXIII Congr.Bras.Geol. Salvador, pp. $101-134$.

INSTITUTO BRASILEIRO DE GEOGRAFIA E ESTATISTICA - 1972 - Folhas Topogräficas de Mogi Mirim e Aguas de Lindöia, : escala 1.50 .000 .

INSTITUTO GEOGRAFICO E GEOLOGICO - 1974 - Mapa Geolögico do Esta do de São Paulo, escala 1:1.000.000.

KRONER, A. - 1977 - The Precambrian Geotectonic Evolution ". of Africa Plate Destruction, Precambrian Res. Est.Sc.Pub1. Co., Vol.4, no 2. pp. 163-213. Amsterdam.

LANDIM, P.M.B. - 1973 - Contribuição ao estudo dos mistitos do Grupo Tubarão no Estado de São Paulo. Escola de : Engenharia de São Carlos. Bol.Geo1. Vo1.17. pp. 1-98. 
LEONARDOS Jr., O.H.; DUNHAM, A.C.; PIRES, F.R.M. E FORMAN, J.M.A. - 1971 - Nota sobre a Formação Pouso Alegre, An. Acad. Bras. Ciênc. Vol. 43 (e): 131-134.

LOCZY, L. e LADEIRA, E.A. - 1976 - Geologia Estrutural e Introdução à Geotectônica. Editora Edgard Blucher Ltda. $528 \mathrm{pp}$. MARTIN, H.; MAU, H. e BJORNBERG, A.J.S. - 1959 - Vale Prë-Glacial a Noroeste de Jundiai, SP. Bol.Soc.Bras.Geol., Vol.8, no 2. pp. $35-40$.

MEHNERT, K.R. - 1968 - Migmatites and the origin of rocks. Elsevier Pub. Comp., New York, $325 \mathrm{pp}$.

MELFI, A.J.; BETTENCOURT, I. e QUEIROZ NETO, J.P. de - 1966 - Observações sobre a Sedimentação Pōst-Cretācea na Região de Campinas, SP. Bol.Soc.Bras.Geol. - Nūcleo Rio de Janeiro,Vol. 1. pp. 83-85.

MENDES, J.C. - 1962 - Problemas paleogeogrāficos do Grupo Tubarão (Carbonifero Superior). Bol. Soc. Bras. Geol. Vol.11, no 2. pp. $71-74$.

MIYASHIRO, A. - 1962 - Notes on rock-forming minerals (22) - Common ocurrence of muscovite rich in iron and magnesium in glau cophanitic metamorphic terrains. Jour. Geol. Soc. Japan. Vol. 68. pp. 234-235.

OLIVEIRA, M.A.F. de - 1973 - Petrologia das rochas metamörficas da região de São José do Rio Pardo (SP). Rev. Bras. Geociēn cias. Vo1.3, no 2. pp. 257-278.

OLIVEIRA, M.A.F. de e ALVES, F.R. - 1974 - Geologia e Petrografia da região de Caconde (SP). Anais do XXVIII Congr. Brasileiro de Geologia. Porto Alegre, Vo1.5. pp. 133-143.

OLIVEIRA, M.A.F. de e ALVES, F.R. - 1976 - Wollastonita em associações calcicas da fácies granulito, Caconde, SP. Rev. Bras. Geol. Vol.6, no 1. pp. 43-52.

OLIVEIRA, M.A.F. de e HIPOLITO, R. - 1973 - Rochas calco-silicāti cas da região de São Josē do Rio Pardo, SP. An. do XXVIII Congr.Bras.Geo1. Porto Alegre. Vo1.5. pp. 133-143.

PENALVA, F. - 1964 - Sedimentos Neocenozötcos dos Rios Jundia 1 , A tibaia e Jaguari. Tese apresentada ao XVIII Congr.Bras.Geol., Poços de Caldas, MG. 
PENALVA, F. e WERNICK, E. - 1973a - Feições estruturais de migma titos ao norte e sul da falha de Jacutinga, leste do Estado de São Pauto. Ciência e Cultura, 25: 183.

PENALVA, F. e WERNICK, E. - 1973b - Compartimentação tectōnica em parte do Prē-Cambriano Paulista. Soc.Bras.Geol. - Nūcleo da Bahia. Boletim Especial nọ I (Resumo das Comunicações do XXVII Congr.Bras.Geol.), Aracaju. pp. 128-129.

PENTEADO, M.M. - 1969 - Novas informações a Respeito dos Pavimeñ tos Detriticos ("stone lines"). Not.Geomorf. Campinas.Vol.9, no 17. pp. 15-41.

PETRI, S. - 1964 - Grupo Tubarão: In "Geologia do Estado de São Paulo". Bol. Inst. Geogr.Geol. Vol.41. pp. 56-63.

PIRES, F.R.M.; LEONARDOS Jr, 0.H. e PARENTI COUTO, J.G. - $1970-$ Gonditos na Região de Pouso Alegre (MG). Min. e Met. 52(312): 237-239.

PRIEM, H.N.A.; BOELRIK, N.A.I.M.; HEBEDA, E.H.; VERDUMEN, E.A. th.; VERCHURE, R.H. and BON, E.H. - 1971 - Granitic comple xes and associeted tin mineralization of Greenville age in Rondonia, W Brasil. Geol. Soc. Bull. 82, 1095-1102 pp.

PROJETO SAPUCAI - 1979 - Relatōrio final de geologia do:SW do Es tado de Minas Gerais e NE do Estado de São Paulo. Ministērio das Minas e Energia - DNPM, Sërie nọ 4, Seção Bāsica :nọ 2. Brasitia. 299 p.

ROCHA CAMPOS, A.C. - 1967 - Problem in Brasilian Gondwana Geology. 2-Tubarão Group. I International Symposium on the Gondwana Stratigraphy and Palaentology. pp. 27-102.

RODRIGUES, J.E. - 1976 - 0 falhamento transcorrente de Jacutinga, Dissertação de Mestrado - IGUSP (Inēdita). 44 pp.

SASSI, F.P. - 1972 - The petrologic and geologic significance of the $b_{0}$ value of potassic white micas in low-grade metamorphic rocks. An application to the Eastern Alps. - Tschermaks Miner. Petr.Mitt. 18: 105-113.

SEDERHOLM, J.J. - 1907 - On granite and gneiss. Bu11. Comm.-Geol. Finlande, 23, $213 \mathrm{pp}$.

SEKI, Y. - 1973 - Basal Spacings of metamorphic white mica and type of metamorphism.Jour.Geo1.Soc.Japan.Vo1.79. pp.611-620. 
SOARES, P.C. - 1972 - O Limite Glacial/Pōs-Glacial do Tubarão,no Estado de São Paulo. An.Acad.Bras.Ciênc.Vol.44 (suplemento): $333-342$.

SOARES, P.C. - 1974 - Elementos estruturais da parte Nordeste da Bacia do Paranā: classificação e gênese. An.do XXVIII Congr. Bras.Ge01. Vol.4.pp. 107-122.

SOARES, P.C. (Coordenador) - 1975 - Projeto Caldas II. Convēnio DNPM/FFCLRC. Relatōrio final $46 \mathrm{pp}$.

SOARES, P.C. e FIORI, A.P. - 1976 - Lögica e sistemātica na anālise e interpretação de fotografias aéreas em geologia. Not. Geomorf. Campinas. Vol. 16, ne 32. pp. 71-104.

SOARES, P.C. e LANDIM, P.M.B. - 1973 - Aspectos regionais da Bacia do Paranā no seu flanco nordeste. Anais do XXVII Congr. Bras.Geol. Aracajü. Vol.1. pp. 243-256.

SOARES, P.C. e LANDIM, P.M.B. - 1975 - Cenozoic deposits in South Brasil.Intern. Simp.on the Quaternary. Bol.Paran. Geoc. Vo1.17, no 33. (Abstract).

SOARES, P.C.; LANDIM, P.M.B.; SINELLI, 0.; FU-TAI, W. e FIORI,A. P. - 1977 - Associações Litológicas do Subgrupo Itararē e sua interpretação ambiental. Rev.Bras.Geol., Vol.4, no 2.pp. $131-149$.

SOARES, P.C.; SINELLI, 0.; PENALVA, F.; WERNICK, E.; SOUZA, A. e CASTRO, P.R.M. - 1973 - Geologia do Nordeste do Estado: de São Paulo. Anais do XXVIII Congr.Bras.Geol., vol.1. pp. 209228.

SPRY, A. - 1974 - Metamorphic Textures. Pergamon Press Ltd. New York, $350 \mathrm{pp}$.

THOMPSON, A.B. - 1974 - Calculation of muscovite-paragonite-alka 1 i feldspar phase relations. Contr.Mineral. Petrol., Vol.44. pp. $173-194$.

TORQUATO, J.R. - 1974 - Geologia do SW de Moçãmedes e suas relações com a evolução tectónica de Angola. Tese de Doutoramento - IGUSP (inëdita). $243 \mathrm{p}$.

TUTTLE, 0.F. - 1949 - Structural petrology of planes of liquid inclusions. Journ.Geol., Vol.57, no 4. pp. 331-356. 
ULBRICH, H.H.G.J.; ULBRICH, M.N. e BAGNOLI, E. - 1977 - Contributions to the petrology of the Poços de Caldas Alkali Massif, Brasil. I: Petrography and structure of the Poços de Caldas Lujavrite. IGUSP (inēdito). 42 p.

VANDOROS, P. e FRANCO, R.R. - 1966 - Determinação de idade de granitos da região de Mogi das Cruzes, São Paulo, pelos mēto dos K-Ar e Rb-Sr. An.Acad.Bras.Ciênc. Vol.38, nọ 2. pp. 289292.

VELDE, B. - 1965 - Experimental determination of muscovite polymorph stabilities. Amer.Mineral. Vol. 50, no 4. pp. 436-449. VELDE, B. - $1967-\mathrm{Si}^{4+}$ content of natural phengites. Contr. Mineral. Petrol.Vol.14, no 2. pp. 250-258.

VELDE, B. - 1972 - Celadonite mica: Solid solution and stability. Contr.Mineral. Petrol. Vol.37, no 3. pp. 235-247.

WASHBURNE, C.W. - 1930 - Petroleum geology of State of São Pau10. Com.Geogr.Geol. de São Paulo. Bol. 22. 58 p.

WENK, E. - 1970 - Distribution of Al between coexisting micas in metamorphic rocks from the Central Alps. Contr. Mineral. and Petrol. Vol.26. pp. 50-61.

WERNICK, E. - 1967 - A geologia na região de Amparo (leste do Es tado de São Paulo). UNESP - Rio Claro. Tese de Doutoramento: $235 \mathrm{pp}$.

WERNICK, E. - 1972a - Sobre a ocorrência de rochas calco-silicāticas nas proximidades de Duas Pontas, Município de Arcadas, leste do Estado de São Paulo. Ciēnc. e Cult., Vol.24 nọ 4 . pp. 358-367.

WERNICK, E. - 1972b - Granitos pörfiros dos arredores de Serra Negra, Valinhos e Amparo e suas relações com o Maciço de Morungaba, leste do Estado de São Paulo. Rev. Bras.Geoc.Vol.2, nọ 2. pp. 129-138.

WERNICK, E. - 1972c - A geologia do maciço granǐtico de Morungaba, leste do Estado de São Paulo. Escola de Engenharia de São Carlos. Bol.Geol. Vol.16.pp. 110.

WERNICK, E. - 1977 - (Coordenador) "Projeto Ouro Fino", Relatō rio final. Convênio D.N.P.M./F.F.C.L.R.C. - Geologia. 97 pp. WERNICK, E. - 1978a - Contribuição à estratigrafia do Prē- Cam- 
briano do leste do Estado de São Paulo e äreas vizinhas.Rev. Bras.Geoc., Vo1.8, nọ 3..pp. 206-216.

WERNICK, E. - 1978b - Contribuição à geologia do Maciço de Guaxu pē, SP e MG. An.Acad.Bras.Ciênc.Vol. 50, nọ 3. pp. 337-352.

WERNICK, E. e ARTUR, A.C. - 1974 - Petrofabric de migmatitos dos arredores de Amparo, SP. Rev. Bras.Geoc., Vo1.4, no 1. pp.27 39.

WERNICK, E. e FERNANDES, N.A. - 1972 - Triclinicidade de feldspa tos potāssicos de rochas granīticas do maciço de Morungaba, SP. An. XXVI Congr.Bras.Geo1., Be1ēm. Vol.1. pp. 51-56.

WERNICK, E. e FIORI, A.P. - 1979 - Contribuição à geologia da borda Sul do Craton de São Francisco. (no prelo).

WERNICK, E. e GOMES, C.B. - 1977 - Geoquïmica de maciços granītị cos da região do Ribeira. Parte III: considerações petrolōgi cas. An.Acad.Bras.Ciênc.Vol. 49, nọ 1. pp. 157-169.

WERNICK, E. e PENALVA, F. - 1973 - As relações entre os Grupos Amparo e Itapira (SP). Soc.Bras.Geol. Nūcleo da Bahia. Boletim Especial nọ 1 (Resumo das comunicações do XXVIII Congr. Bras.Geo1.). pp. 116-117.

WERNICK, E. e PENALVA, F. - 1974a - Migmatização e feldspatiza ção de charnockitos e granulitos no leste paulista e sul de Minas Gerais. Anais do XXVIII Congr.Bras.Geol., Porto Alegre. Vo1.5.pp. 155-160.

WERNICK, E. e PENALVA, F. - 1974b - Depósitos molassöides da For mação Eleutērio, SP - MG. Soc.Bras.Geol. Nücleo Rio Grande do Sul. Boletim especial nọ 1. (Resumo das Comunicações do XXVIII Congr.Bras.Geol.). pp. 723-726.

WERNICK, E. e PENALVA, F. - 1978 - Contribuição ao conhecimento das rochas granitöides do sul do Brasil. Rev.Bras.Geoc., Vol. 8, no 2. pp. 113-133.

WERNICK, E. e PENALVA, F. - 1980 - 0 Grupo Pinhal na Região Nordeste do Estado de São Paulo e Areas Vizinhas do Estado de Minas Gerais. Bo1. IGUSP., Vo1. 11. pp. 1-20.

WERNICK, E.; FERNANDES, N.A. e ALMEIDA. Jr, N.F. - 1976a - Gonditos de Socorro e Itapira, SP. Min. Meta1., Vol. 39 (372):16$21 \mathrm{pp}$. 
WERNICK, E.; PANTOJA, J.L. e NICOLA, J.P. - 1976c - Megacristais do maciço granītico de Socorro (SP e MG). Soc.Bras.Geol. Nū cleo de Minas Gerais. Boletim Especial nọ 1. (Resumo das Comunicações do XXIX Congr.Bras.Geo1.). pp. 329.

WERNICK, E.; FIORI, A.P.; BITTENCOURT, J.S. e CHOUDHURI, A. 1979 - A tectônica rīgida do fim do Ciclo Brasiliano e sua implicação na estruturação da borda $S$ e SW do Craton do São Francisco: Tentativa de um modelo preliminar. (no prelo).

WERNICK, E.; OLIVEIRA, M.A.F.de; KAWASHITA, H.; CORDANI, U.G. e DELHAL, J. - 1976b - Estudo geocronolōgico pelo método RbSr em rochas do Bloco Jundiaí e regiões adjacentes. Rev. Bras. Geoc., Vol.6, no 1. pp. 125-135.

WILLIAMS, H.; TURNER, F.J. e GILBERT, C.M. - 1970 - Petrografia. EDUSP-Ed.Polígono, São Paulo. 445 .

WINKLER, H.G.F. - 1976 - Petrogenesis of metamorphic rocks.Sprin ger Verlag. 4th ediction, $334 \mathrm{p}$.

WINTERS, A.A.M. e EBERT, H. - 1978 - 0 maciço sienītico de Pedra Branca, Município de Caldas (MG). An. XXX Congr.Bras. Geol. Recife. Vol.3, pp. 1364-1370. 
APENDICE 1 - DADOS ANALITIICOS RD-ST (ANALLISES EM ROCHA TOTAL)

\begin{tabular}{|c|c|c|c|c|c|c|c|c|}
\hline $\begin{array}{c}\text { No } \\
\text { Labor. }\end{array}$ & $\begin{array}{c}\text { NQ } \\
\text { Campo }\end{array}$ & Rocha & $\begin{array}{c}\mathrm{Rb} \\
(\mathrm{ppm})\end{array}$ & $\begin{array}{c}\mathrm{Sr} \\
(\mathrm{ppm})\end{array}$ & $\mathrm{sr}^{87} / \mathrm{sr}^{86^{*}}$ & $\mathrm{Rb}^{87} / \mathrm{Sr}^{86}$ & R.I."* & $\begin{array}{c}\text { Idade Conv. } \\
\text { m.a. }\end{array}$ \\
\hline 3085 & $14 B$ & Biot.Gn.Porfirobl. & 157,7 & 139,9 & 0,825 & 3,30 & 0,703 & $2545 \pm 88$ \\
\hline 2676 & $14 C$ & Biot.Gn.Porfirobl. & 138,5 & 192,3 & 0,766 & 2,10 & 0,703 & $2085 \pm 94$ \\
\hline 3148 & 140 & Biot.Gn.Porfirobl. & 127,0 & 274,1 & 0,744 & 1,35 & 0,703 & $2117 \pm 127$ \\
\hline 2677 & $14 E$ & Biot.Gn.Porfirobl. & 123,2 & 284,5 & 0,739 & 1,26 & 0,703 & $1973 \pm 150$ \\
\hline 3086 & $14 \mathrm{~F}$ & Biot.Gn.Porfirobl. & 110,6 & 281,0 & 0,737 & 1,14 & 0,703 & $2086 \pm 139$ \\
\hline 3087 & $14 \mathrm{H}$ & Biot.Gn.Porfirobl. & 109,9 & 188,0 & 0,752 & 1,70 & 0,703 & $1988 \pm 103$ \\
\hline 3413 & $14 J-1$ & Biot.Gn.Porfirobl. & 125,9 & 268,1 & 0,745 & 1,36 & 0,703 & $2130 \pm 120$ \\
\hline 3414 & $14 L$ & Biot.Gn.Porfirobl. & 182,5 & 173,4 & 0,796 & 3,07 & 0,703 & $2100 \pm 81$ \\
\hline 2906 & $14 M$ & Gnaisse Granitico & 182,1 & 56,4 & 1,006 & 9,63 & 0,703 & $2181 \pm 64$ \\
\hline 2905 & $14 Q$ & Gnaisse Granitico & 174,2 & 84,7 & 0,893 & 6,07 & 0,703 & $2174 \pm 67$ \\
\hline 3496 & 145 & Gnaisse Granitico & 201,6 & 34,4 & 1,249 & 17,88 & 0,703 & $2116 \pm 61$ \\
\hline 3149 & 43 & Anfibolito & 14,3 & 186,3 & 0,707 & 0,22 & 0,703 & \\
\hline 2839 & 180 & Biot.Hornb.Gnaisse & 85,3 & 304,4 & 0,733 & 0,81 & 0,711 & $1882 \pm 196$ \\
\hline 3088 & $18 \mathrm{E}$ & Biot.Hornb.Gnaisse & 106,7 & 184,6 & 0,752 & 1,68 & 0,711 & $1703 \pm 104$ \\
\hline 2681 & $18 \mathrm{~F}$ & Biot. Hornb.Gnaisse & 60,5 & 288,8 & 0,728 & 0,61 & 0,711 & $1970 \pm 239$ \\
\hline 3089 & $18 G$ & Biot.Hornb.Gnaisse & 108,1 & 204,4 & 0,753 & 1,54 & 0,711 & $1903 \pm 112$ \\
\hline 2887 & $18 \mathrm{~J}$ & Biot.Hornb.Gnaisse & 109,0 & 229,3 & 0,751 & 1,38 & 0,711 & $1986 \pm 125$ \\
\hline 2381 & $19 A$ & Biotita Gnaisse & 111,8 & 556,5 & 0,725 & 0,58 & 0,7065 & \\
\hline 2886 & 198 & Biotita Gnaisse & 143,2 & 315,4 & 0,751 & 1,32 & 0,7065 & $2230 \pm 133$ \\
\hline 2828 & 196 & Biotita Gnaisse & 110,7 & 443,1 & 0,732 & 0,72 & 0,7065 & $2309 \pm 210$ \\
\hline 3083 & I9E & Biotita Gnaisse & 128,9 & 195,8 & 0,770 & 1,92 & 0,7065 & $2217 \pm 99$ \\
\hline 3084 & 196 & Biotita Gnaisse & 153,6 & 293,4 & 0,757 & 1,52 & 0,7065 & $2206 \pm 118$ \\
\hline 2907 & $22 \mathrm{~A}$ & Gnaisse Granitico & 88,0 & 237,0 & 0,750 & 1,08 & 0,7275 & \\
\hline 2908 & $22 \mathrm{E}$ & Gnaisse Granitico & 130,6 & 193,4 & 0,769 & 1,96 & 0,7275 & $1411 \pm 91$ \\
\hline 2909 & $22 \mathrm{~F}$ & Gnaisse Granitico & 127,1 & 193,9 & 0,766 & 1,90 & 0,7275 & $1380 \pm 88$ \\
\hline 2890 & $58 B$ & Migmatito & 60,8 & 425,0 & 0,717 & 0,41 & 0,713 & \\
\hline 3417 & $59 A-1$ & Migmatito & 205,1 & 122,0 & 0,757 & 4,89 & 0,713 & $629 \pm 37$ \\
\hline 2892 & $59 B$ & Migmatito & 38,6 & 467,3 & 0,718 & 0,24 & 0,713 & \\
\hline 2893 & $59 C$ & Migmatito & 66,8 & 408,2 & 0,716 & 0,47 & 0,713 & \\
\hline 3415 & 590 & Migmatito & 239,7 & 128,0 & 0,755 & 5,44 & 0,713 & $538 \pm 32$ \\
\hline 3416 & $59 E$ & Migmatito & 33,2 & 543,0 & 0,713 & 0,18 & 0,713 & \\
\hline 2891 & $59 \mathrm{~A}$ & Migmatito & 230,4 & 109,5 & 0,759 & 6,12 & 0,713 & $524 \pm 32$ \\
\hline 3091 & $100 \mathrm{~F}$ & Biotita Gnaisse & 148,1 & 218,4 & 0,765 & 1,97 & 0,734 & $1102 \pm 88$ \\
\hline 3090 & $100 \mathrm{G}$ & Biotita Gnaisse & 152,5 & 166,8 & 0,777 & 2,66 & 0,734 & $1117 \pm 64$ \\
\hline 2872 & $100 \mathrm{H}$ & Biotita Gnaisse & 127,6 & 225,6 & 0,763 & 1,64 & 0,734 & $1210 \pm 117$ \\
\hline 3412 & $100 \mathrm{~J}$ & Biotita Gnaisse & 144,8 & 159,0 & 0,778 & 2,65 & 0,734 & $1156 \pm 64$ \\
\hline
\end{tabular}

Constantes utilizadas:

$\lambda_{R b}=1,42 \times 10^{-11}$ anos $^{-1}$

$R b^{85} / R b^{87}=2,59$

* valores normalizados para $5 r^{86} / \mathrm{Sr}^{88}=0,1194$

** razão inicial 


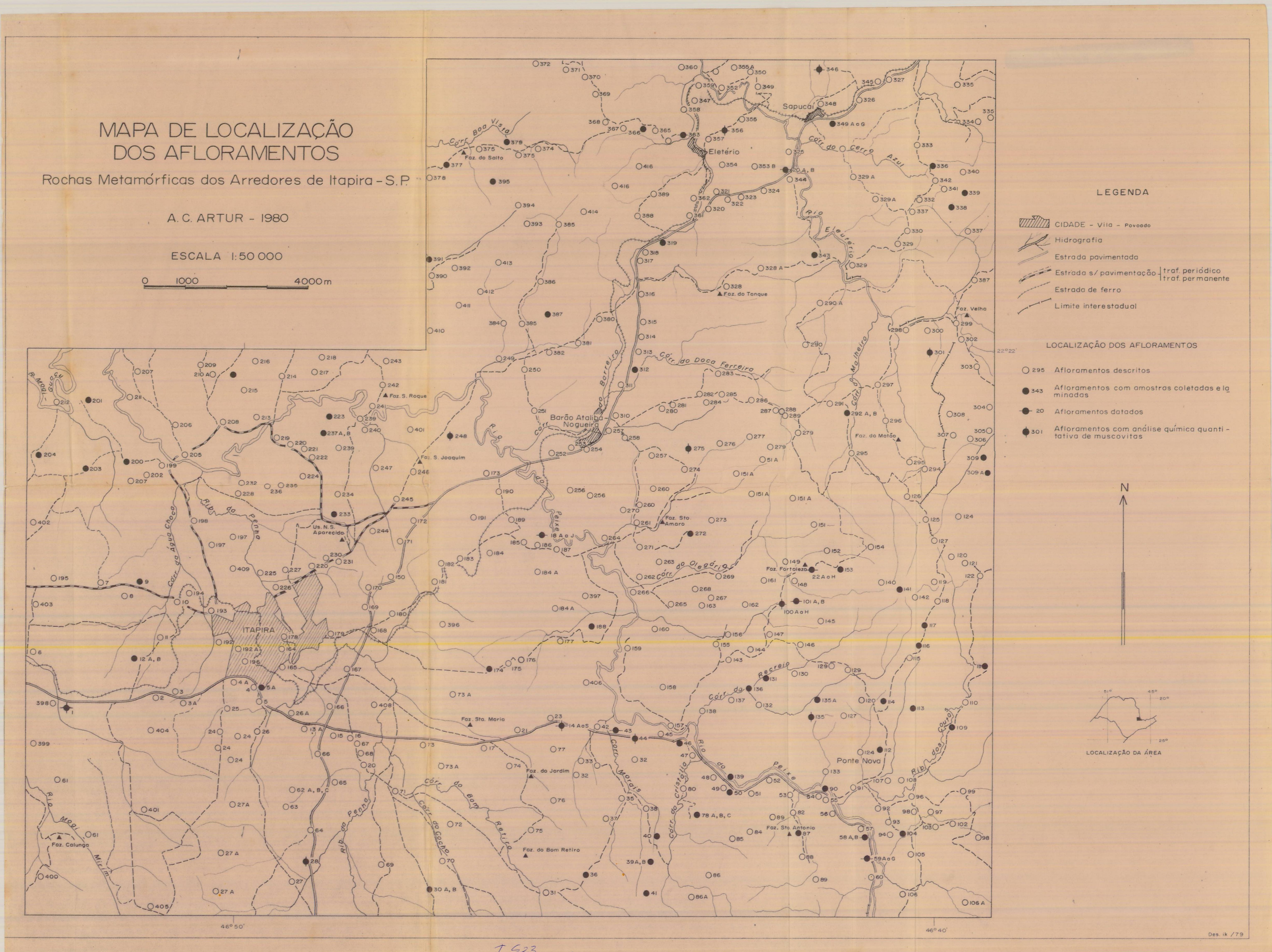


MAPA LITOLÓGICO ESTRUTURAL DOS ARREDORES DE ITAPIRA - SP

Geologia por: A. C. ARTUR

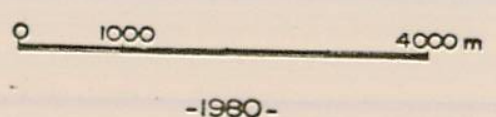

$-1980-$

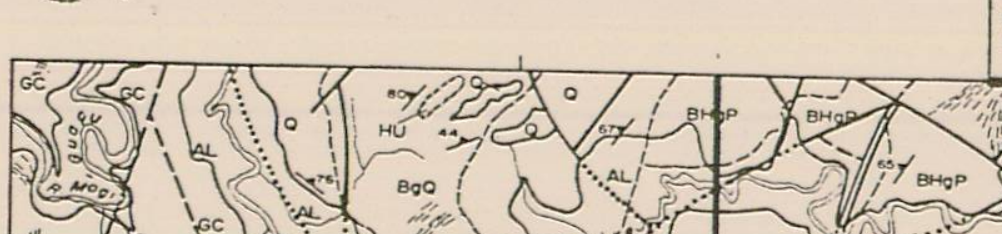

exos



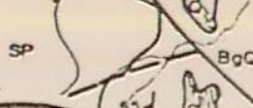

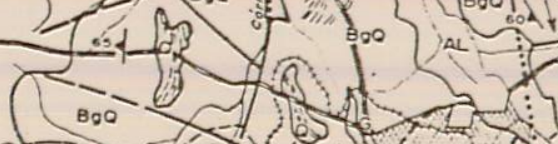

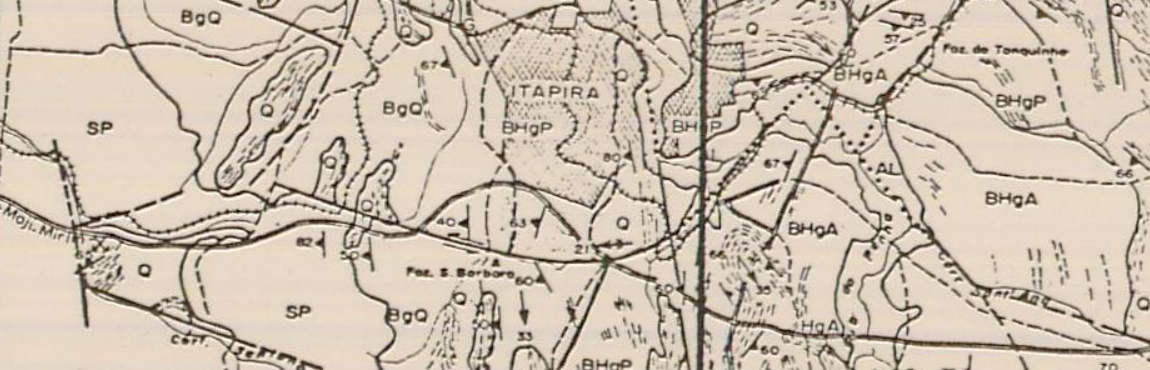

sp

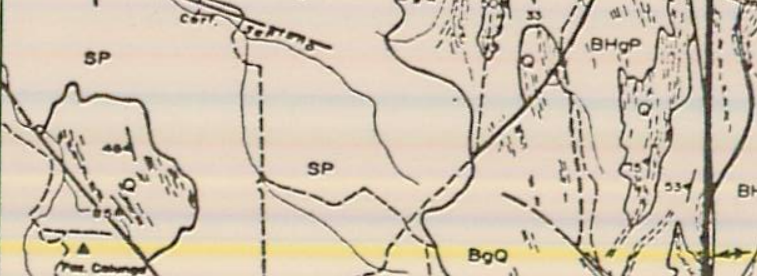

(1)

Setor -1



tr.

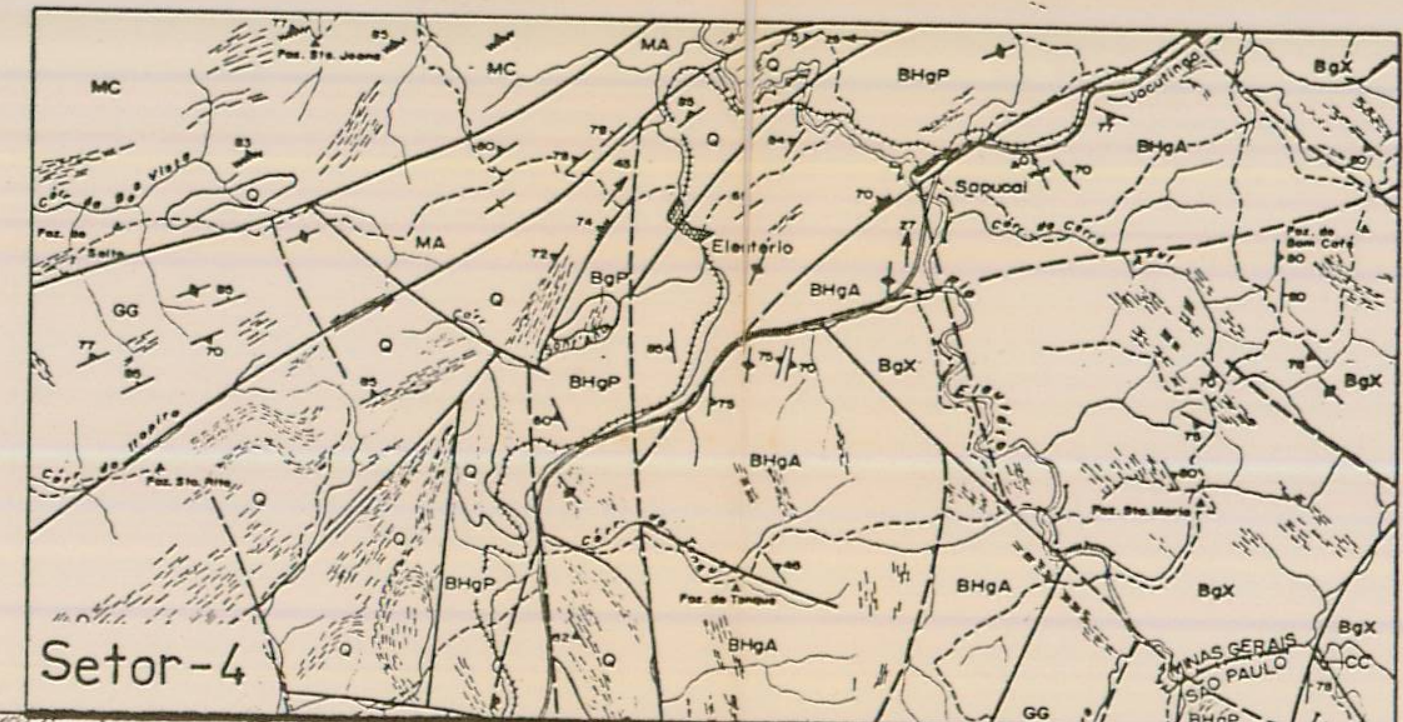

FIDADE - VIID

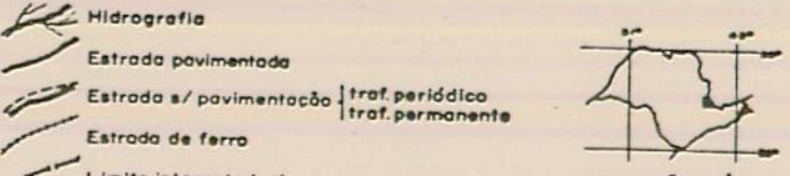

Limite interestodual



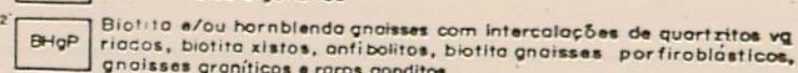
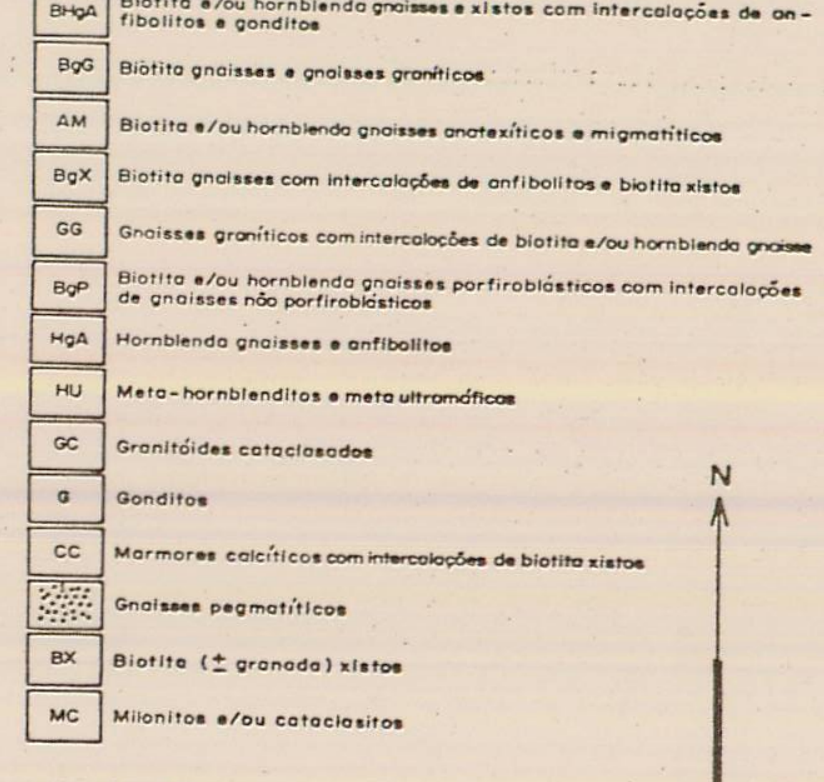

$x$ Poorairo

* Afividodo minoiro

Contoto verificado

Contoto interido

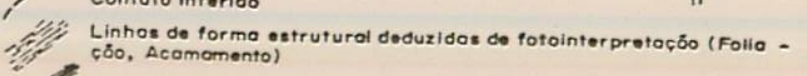

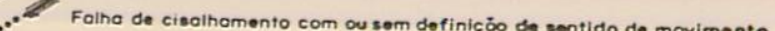

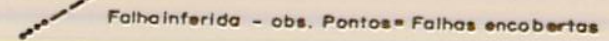

N" Ela do dobros menores

T. Linooşo

Dofy Atitude de ocamomento (inclinodo e verticol)

Sox Atitude do folliagso (inclinodo e vertical)

A Atitude do folliocbo em milonito (inclinada e vertical) 